\title{
Direito empresarial, tributário e financeiro
}

Antônio Carlos Diniz Murta, Rafael Peteffi da Silva, Raymundo Juliano Feitosa, Valter Moura do Carmo

(coords.) 



\section{COMITÉ CIENTÍFICO}

\section{SERIE LEFIS}

\section{Coordinación}

Prof. Fernando Galindo Ayuda. Universidad de Zaragoza

Profa. María Pilar Lasala Calleja. Universidad de Zaragoza

Consejo asesor

Prof. Javier García Marco. Universidad de Zaragoza

Prof. Alejando González-Varas Ibáñez. Universidad de Zaragoza

Prof. Philip Leith. Universidad Queen's de Belfast

Prof. Emérito Abdul Paliwala. Universidad de Warwick

Prof. Aires Rover. Universidad Federal de Santa Catarina

Prof. Erich Schweighofer. Universidad de Viena

Prof. Ahti Saarenpää. Universidad de Rovaniemi 
DIREITO EMPRESARIAL,

TRIBUTÁRIO E FINANCEIRO 



\section{DIREITO EMPRESARIAL, TRIBUTÁRIO E FINANCEIRO}

Antônio Carlos Diniz Murta, Rafael Peteffi da Silva, Raymundo Juliano Feitosa, Valter Moura do Carmo (coords.) 
DIREITO empresarial, tributário e financeiro [Recurso electrónico] / Antônio Carlos Diniz Murta... [et al.] (coords.). - Zaragoza : Prensas de la Universidad de Zaragoza, 2019

250 p. ; $22 \mathrm{~cm}$. - (LEFIS series ; 20)

ISBN 978-84-17633-54-7

1. Informática-Derecho-Brasil. 2. Internet en la administración pública. 3. Derecho empresarial-Brasil. 4. Derecho fiscal-Brasil

MURTA, Antônio Carlos Diniz

34(81):004

004.738.5:35

004.738:347.72(81)

004.738:351.713(81

Cualquier forma de reproducción, distribución, comunicación pública o transformación de esta obra solo puede ser realizada con la autorización de sus titulares, salvo excepción prevista por la ley. Diríjase a CEDRO (Centro Español de Derechos Reprográficos, www.cedro.org) si necesita fotocopiar o escanear algún fragmento de esta obra.

(C) LEFIS

(C) CONPEDI, Conselho Nacional de Pesquisa e Pós-Graduação em Direito Brasil.

(C) De la presente edición, Prensas de la Universidad de Zaragoza (Vicerrectorado de Cultura y Proyección Social)

1. ${ }^{\text {a }}$ edición, 2019

El Centro Universitário de João Pessoa - PB - UNIPÊ ha subvencionado parcialmente la edición de este libro.

Prensas de la Universidad de Zaragoza. Edificio de Ciencias Geológicas, c/ Pedro Cerbuna, 12. 50009 Zaragoza, España. Tel.: 976761 330. Fax: 976761063

puz@unizar.es http://puz.unizar.es

https://www.conpedi.org.br/

Esta editorial es miembro de la UNE, lo que garantiza la difusión y comercialización de sus publicaciones a nivel nacional e internacional. 


\section{SUMÁRIO}

\section{DIREITO EMPRESARIAL}

APRESENTAÇÃO

Rafael Peteffi da Silva, Valter Moura do Carmo.

A CONTRIBUIÇÃO DO PROGRAMA DE AGENTES LOCAIS DE INOVAÇÃO (ALI) PARA AS MICRO E PEQUENAS EMPRESAS BRASILEIRAS.

Adalberto Simão Filho.

A EQUIVOCADA APLICAÇÃO DO PRINCÍPIO DE PRESERVAÇÃO DA EMPRESA COMO FUNDAMENTO DE EXTINÇÃO DE PEDIDOS DE FALÊNCIA: ALGUMAS HIPÓTESES JURISPRUDENCIAIS.

Rafael Peteffi da Silva, Adriana Santos Ramme.

ANÁLISE ECONÔMICA DO DIREITO E SUA APLICAÇÃO NO BRASIL: UM ESTUDO A PARTIR DO PARADIGMA DO ESTADO DEMOCRÁTICO DE DIREITO NA CONSTITUIÇÃO DA REPÚBLICA FEDERATIVA DO BRASIL DE 1988. .46

Leonardo José Peixoto Leal, Valter Moura do Carmo.

AS PATENTES DE INVENÇÕES NA LEGISLAÇÃO BRASILEIRA COMO INTERESSE SOCIAL E DESENVOLVIMENTO TECNOLÓGICO E ECONÔMICO DO PAÍS. .69

Querino Mallmann.

NANOTECNOLOGIA, ASPECTOS JURIDICOS ECONOMICOS DA CIENCIA DO FUTURO.

Claudino Gomes, Murilo Couto Lacerda.

SOCIEDADE INSTITUCIONAL NO DIREITO BRASILEIRO?..... 104 Alexandre de Albuquerque Sá.

\section{DIREITO TRIBUTÁRIO E FINANCEIRO}

APRESENTAÇÃO

Raymundo Juliano Feitosa, Antônio Carlos Diniz Murta.

A TRANSPARÊNCIA NA TROCA DE INFORMAÇÕES ENTRE A ADMINISTRAÇÃO TRIBUTÁRIA E OS CONTRIBUINTES NO CONTEXTO DA AÇÃO 12 DO PLANO BEPS.

Renata Gomes de Albuquerque Sá.

EXCLUSÃO DO ICMS DA BASE DE CÁLCULO DO PIS E DA COFINS: O SUPREMO TRIBUNAL FEDERAL DEVE MODULAR OS EFEITOS?....

Maria de Fatima Ribeiro, Lucas Pires Maciel.

O CONCEITO DE TAXA E A ESSENCIALIDADE DO SERVIÇO PÚBLICO: ANÁLISE DO TEMA N ${ }^{\circ} 16$ DA REPERCUSSÃO GERAL NO SUPREMO TRIBUNAL

Antônio Carlos Diniz Murta, Carlos Victor Muzzi Filho. 
O EQUILÍBRIO NA POLÍTICA DE DISTRIBUIÇÃO DE DIVIDENDOS NAS EMPRESAS ESTATAIS

Gabriel Senra da Cunha Pereira, Edimur Ferreira De Faria.

O PRINCÍPIO DA EFICIÊNCIA DA EXECUÇÃO FISCAL EM PAÍSES DA AMÉRICA LATINA E NA ESPANHA: UM PARALELO ENTRE MODELOS JUDICIAIS E A COBRANÇA ADMINISTRATIVA DO CRÉDITO TRIBUTÁRIO

Flávio Couto Bernardes, Karol Araujo Durço.

REIDI, PIS E COFINS E AS CONCESSIONÁRIAS DE ENERGIA: DA NECESSIDADE DE DAR EFETIVIDADE AO BENEFÍCIO FISCAL À LUZ DOS PRINCÍPIOS DO EQUILÍBRIO ECONÔMICO-FINANCEIRO E DA DURAÇÃO RAZOÁVEL DO PROCESSO.

Alexandre Naoki Nishioka, Gabriel de Carvalho Thielmann. 


\section{DIREITO EMPRESARIAL}

\section{APRESENTAÇÃO}

Os artigos hora publicados foram apresentados no Grupo de Trabalho Direito Empresarial, durante o VIII ENCONTRO INTERNACIONAL DO CONPEDI, realizado em Zaragoza(Espanha), entre os dias 06 a 08 de setembro de 2018. O evento foi promovido pelo Conselho Nacional de Pesquisa e Pós-Graduação em Direito - CONPEDI em parceria com a Universidade de Zaragoza - UNIZAR, com o tema Direito, argumentação e comunicação: Desafios para o século XXI. O evento ainda contou com o apoio do Centro Universitário de João Pessoa - UNIPÊ.

Os trabalhos apresentados abriram caminho para importantes discussões, com a participação ativa de professores, pesquisadores, mestrandos e doutorandos do Brasil e da Espanha. O evento contribuiu significativamente para a apresentação dos resultados das pesquisas realizadas pelos Programas de Pós-Graduação em Direito do Brasil e a troca de conhecimentos entre os dois países.

Nesse sentido, foram apresentados no âmbito do GT de Direito Empresarial, temas absolutamente relevantes para o desenvolvimento do Direito no Brasil e da Espanha, tais como:

1. A CONTRIBUIÇÃO DO PROGRAMA DE AGENTES LOCAIS DE INOVAÇÃO (ALI) PARA AS MICRO E PEQUENAS EMPRESAS BRASILEIRAS.

2. A EQUIVOCADA APLICAÇÃO DO PRINCÍPIO DE PRESERVAÇÃO DA EMPRESA COMO FUNDAMENTO DE EXTINÇÃO DE PEDIDOS DE FALÊNCIA: ALGUMAS HIPÓTESES JURISPRUDENCIAIS.

3. ANÁLISE ECONÔMICA DO DIREITO E SUA APLICAÇÃO NO BRASIL: UM ESTUDO A PARTIR DO PARADIGMA DO ESTADO DEMOCRÁTICO DE DIREITO NA CONSTITUIÇÃO DA REPÚBLICA FEDERATIVA DO BRASIL DE 1988. SOCIAL E DESENVOLVIMENTO TECNOLÓGICO E ECONÔMICO DO PAÍS. 
5. NANOTECNOLOGIA, ASPECTOS JURIDICOS ECONOMICOS DA CIENCIA DO FUTURO.

6. SOCIEDADE INSTITUCIONAL NO DIREITO BRASILEIRO?

Coordenadores do GT:

Prof. Dr. Rafael Peteffi da Silva - UFSC

Prof. Dr. Valter Moura do Carmo - UNIMAR 


\title{
A CONTRIBUIÇÃO DO PROGRAMA DE AGENTES LOCAIS DE INOVAÇÃO (ALI) PARA AS MICRO E PEQUENAS EMPRESAS BRASILEIRAS
}

\author{
Adalberto Simão Filho \\ Universidade de Ribeirão Preto-Unaerp-Brasil
}

\begin{abstract}
Resumo
O Programa Ali- Agentes Locais de Inovação, desenvolvido a partir de um convenio entre o SEBRAE- Serviço Brasileiro de Apoio às Micro e Pequenas Empresas e CNPQ- Conselho Nacional de Desenvolvimento Científico e Tecnológico, estruturalmente se coloca como uma das mais eficientes e promissoras atividades que envolvem a iniciativa privada, entes públicos de pesquisa e meio acadêmico, gerando resultados e frutos que são colhidos com saciedade pelos empresários, contribuindo para a inovação e refletindo na construção de uma nova empresarialidade voltada para valores éticos e de responsabilidade social, como se pretende demonstrar nesta pesquisa de campo.
\end{abstract}

Palavras-chave: radar de inovação, metodologia SEBRAE, programa agente local de inovação, solidarismo, ética empresarial,micro e pequena empresa.

\section{Abstract/Resumen/Résumé}

El Programa Ali- Agentes Locales de Innovación, desarrollado a partir de un convenio entre el SEBRAE-Servicio Brasileño de Apoyo a las Micro y Pequeñas Empresas y CNPQ- Consejo Nacional de Desarrollo Científico y Tecnológico, estructuralmente se coloca como una de las más eficientes y que promueven actividades que involucran a la iniciativa privada, entes públicos de investigación y medio académico, generando resultados y frutos que son cosechados con saciedad por los empresarios, contribuyendo a la innovación y reflejando en la construcción de una nueva empresarialidad volcada hacia valores éticos y de responsabilidad social, como se pretende demostrar en esta investigación de campo.

\section{Keywords/Palabras-claves/Mots-clés}

Radar de innovación, metodología SEBRAE, programa agente local de innovación, el solidarismo, ética empresarial, micro y pequeña empresa. 


\section{Introdução}

A atividade empresarial encontra-se em constante evolução e, em tempos de acirrada crise econômico financeira que acaba por afetar sensivelmente os micro e pequenos empreendedores alem dos vários setores da economia, oportunas são as propostas governamentais que possam contribuir para o auxílio no desenvolvimento da micro e pequena empresa brasileira, haja vista a importância deste setor no cenário nacional, quer como gerador de postos de trabalho e cargas tributárias expressivas, como também para o auxílio no seu crescimento e fomento, com claros reflexos no aquecimento da economia.

$\mathrm{O}$ artigo que se apresenta, adota a metodologia de pesquisa quantitativa de campo a partir da observação de fatos específicos apontados e da coleta de material concernente à realidade a ser pesquisada no âmbito de um programa brasileiro denominado ALI - Agentes Locais de Inovação, destinado ao auxílio ao micro e pequeno empresário.

O Sebrae é uma entidade associativa de direito privado, sem fins lucrativos, instituída sob forma de serviço social autônomo, desvinculada da administração pública, criada pela Lei 8.092/9, regulamentado pelo Decreto n.99570/90, alterado pela lei 8.154/90, que ao buscar o seu fim social oportuniza aos empresários de pequeno porte e interessados, a possibilidade de conhecerem ferramentas e de se submeterem à aplicação de metodologias testadas que os auxiliem não só a passar pelas dificuldades atinentes a este período de crise sistêmica, como também a possibilitar uma ambiência inovadora.

O programa brasileiro desenvolvido para a formação de Agentes Locais de Inovação (Programa ALI) é implementado por uma vasta equipe composta de Coordenador Nacional, Coordenador Estadual, Gestor Local, Consultores, Orientadores e por Agentes Locais de Inovação (ALI) que são bolsistas selecionados a partir de um convenio entre o SEBRAEServiço Brasileiro de Apoio às Micro e Pequenas Empresas e CNPQ- Conselho Nacional de Desenvolvimento Científico e Tecnológico voltado para as consecuções do objetivo macro que entre outras finalidades, pretende diagnosticar as questões relevantes que possam interferir de alguma forma, na relação oferta-demanda, bem como estimular a inovação, através de soluções propostas e desenvolvidas pelo programa.

Faz parte do ideário do programa a disponibilização de um orientador para um grupo de Agentes de inovação, para que estes possam desenvolver um artigo específico sobre a trajetória ALI e um estudo de caso pesquisado e coletado no âmbito das empresas que lhes são destinadas, voltados para a experiência de campo adquirida. 
Este artigo é desenvolvido a partir da experiência de orientação de Agentes Locais de Inovação relacionados ao SEBRAE-ER,Capital Leste I de São Paulo, desenvolvida como bolsista do CNPQ, durante o período de 01 de junho de 2016 a 30 de novembro de 2017.

Atribui-se o caráter extensionista ao programa, em razão de seu propósito precípuo de buscar a realização de ações com empresas, estendendo projetos para o meio acadêmico e universidades através da idealização de três eixos nucleares de atuação voltados para a solução e produtos; prospecção e articulação do conhecimento e extensão tecnológica com vistas a aprimorar a pesquisa e tecnologia metodológica.

A revisão de literatura que é formulada, parte exatamente de referenciais teóricos desenvolvidos para orientadores no âmbito do Programa ALI, pelo próprio SEBRAE, adicionados a referenciais técnicos das ciências jurídicas e econômicas tais como Kotlher, Armstrong, Simão Filho.

Mesmo em se tratando de um artigo voltado para a análise de campo, apresenta-se a hipótese consistente da verificação dos reflexos deste programa ALI na visão teórica jurídica da nova empresarialidade, cujo lineamento será melhor desenvolvido mais adiante, notadamente para demonstrar que as ferramentas disponibilizadas no programa, contribuem para o desenvolvimento de uma nova consciência empresarial eivada de valores éticos, morais e sociais, de cunho desenvolvimentista e inovador.

\section{Aspectos estruturantes do Programa de Agentes Locais de Inovação}

O Programa Agentes Locais de Inovação (Programa ALI) possui abrangência nacional e é resultante de um acordo de cooperação técnica entre o CNPQ e o SEBRAE e objetiva diagnosticar as questões relevantes que possam interferir de alguma forma, na relação ofertademanda, bem como estimular a pratica continua da inovação, através de soluções proativas e propostas personalizadas e gratuitas, desenvolvidas a partir do resultados obtidos nos setores empresariais específicos onde já houve atuação.

Os Agentes Locais de Inovação (ALI) são bolsistas selecionados e capacitados a partir do convenio cooperativo entre o SEBRAE e CNPQ e, alem das funções específicas que realizam no âmbito do diagnóstico e da propagação da inovação por meio de ferramentas específicas, possuem o dever de elaborarem um artigo voltado para o mercado e um estudo de caso específico, a ser definido no âmbito das empresas que lhes foram designadas.

Estes Agentes Locais de Inovação (ALI) são responsáveis pela visitação das empresas com vistas a elaboração do diagnóstico e da oferta de soluções e propostas de mudanças que 
possam redundar na melhoria da gestão empresarial, produtos e processos e, até, na busca de novos nichos e segmentos de mercados, sempre observando certas etapas assim sintetizadas:

-Sensibilização: momento em que a empresa tem contato com a proposta do programa ALI.

-Adesão: momento em que a empresa formaliza seu compromisso com o programa ALI.

-Diagnóstico Empresarial: preenchimento, pelo ALI, junto ao empresário.

-Radar da inovação: preenchimento pelo ALI, junto ao empresário.

-Devolutiva: elaborada pelo ALI, a devolutiva é resultado da análise dos dados e evidências coletadas no Diagnóstico Empresarial e do Radar da Inovação.

-Matriz FOFA (forças/fraquezas/ameaças/oportunidades- também conhecida como SWAT) + Plano de Ação: após a entrega da devolutiva, o ALI deverá elaborar a Matriz FOFA e o Plano de ação contendo um mínimo de cinco ações distintas, juntamente com o empresário.

-Início do Plano de Ação e Monitoramento do Plano de Ação: o empresário, acompanhado pelo ALI e supervisionado pelo Consultor Sênior, acompanha a empresa na implantação das ações.

O Agente Local de Inovação efetua o acompanhamento continuado in loco, da empresa e o monitoramento, da implantação das ações inovadoras propostas por cerca de trinta meses, apresentando soluções em consonância com as necessidades empresariais. Um Consultor Sênior especialista dos quadros do SEBRAE efetua a validação das ações propostas pelo ALI.

Muito embora as ações sugeridas possam gerar custos empresariais, os serviços realizados por ALIS são gratuitos, fato que facilita a busca de adesão das empresas que possam ser atendidas pelo programa.

O Orientador dos ALIS, por sua vez, é selecionado pelo sistema de concurso realizado visando a obtenção de bolsa no modelo CNPQ/SEBRAE e tem exatamente a função de auxiliálos nestas etapas, a bem cumprir os ditames metodológicos que possam possibilitar o enriquecimento da experiência, enfrentando mais as questões de fundo voltadas para a atividade empresarial restrita ao universo das micro e pequenas empresas, através de uma visão atual.

A promoção da competitividade e do desenvolvimento sustentável das empresas de micro e pequeno porte é efetivada pelo Sebrae como forma de bem cumprir a sua missão que desenvolve há mais de 40 anos. Atua com foco no fortalecimento do empreendedorismo, auxiliando políticas públicas para a construção de um ambiente mais favorável, na aceleração do processo de formalização da economia, através da oferta de programas de capacitação, acesso ao crédito, mercados e à inovação, estímulo ao associativismo, feiras e rodadas de negócios, além do incentivo às parcerias públicas e privadas. 
O Sebrae atua em todo o território nacional e conta com pontos de atendimento nas 27 Unidades da Federação, precipuamente, na geração de soluções criativas que são desenvolvidas tanto para atender a "start ups" empresariais como para as pequenas e médias empresas que já estão consolidadas e objetivam um novo posicionamento individual.

Além da oferta de atrativos cursos, seminários, consultorias e assistência técnica para pequenos negócios de todos os setores, o Sebrae Nacional é responsável pelo direcionamento estratégico do sistema, definindo diretrizes e prioridades de atuação, possuindo cerca de 7 mil colaboradores diretos e 10 mil consultores e instrutores credenciados que trabalham na transmissão de conhecimentos específicos voltados para negócios.

A partir desta estruturação e destes agentes, o programa ALI foi desenvolvido com êxito e láurea.

\section{A nova empresarialidade como indutora de comportamentos inovadores}

A nova empresarialidade decorre da evolução da atividade empresarial que passa a ser desenvolvida precipuamente com o propósito de se buscar lucros sob forma de resultados, onde se possa considerar também, os agentes que circulam ao redor desta atividade (stackholders) de forma tal que, na busca destes melhores resultados, não se desprezem aqueles que concorreram para a consecução dos mesmos e possa se imprimir um valor social e moral na atividade, aqui designado de ética empresarial.

A expressão nova empresarialidade no contexto ora empregado, na oportunidade de seu desenvolvimento teórico, é entendida como a atividade empresarial em movimento constante e sucessivo, não importando se exercida pela sociedade empresária ou pelo empresário individual e o inter-relacionamento desta com os fornecedores, com o mercado consumidor, com o mercado de valores mobiliários, com os agentes econômicos diversificados, com os trabalhadores, com o meio ambiente e, finalmente com relação aos próprios sócios e acionistas da empresa, gerando uma sinergia completa que culmina em vivificar a empresa e agregar valor. (SIMÃO FILHO et PEREIRA,2014,p.79)

A opção por efetuar a verificação dos reflexos deste programa ALI na visão teórica jurídica mencionada, se faz justamente como forma de se contribuir para o desenvolvimento harmônico da atividade empresarial, principalmente no que tange às micro e pequenas empresas.

Observou-se que o empresário deveria se pautar pela busca da função social quando em trabalho de perseguição de seu objeto social. A impressão de um padrão ético gera a 
imposição de uma regra de conduta no exercício das atividades empresariais contemporâneas de modo a refletir no direito positivo com fins de se possibilitar a afirmação de que se estará delineando um "standard" de bom homem de negócios originário do antigo princípio "bônus pater familiae".

Esta mutação e agregação de valores morais à atividade empresarial contemporânea, pode gerar reflexos no campo jurídico e no seio da sociedade, advindos principalmente, da adoção de padrões éticos e comportamentais por parte dos sócios, administradores e da própria empresa, ligados a princípios que levam em conta valores-objetivos diferentes daqueles que até então norteavam o curso do comércio voltados apenas e tão só para o lucro puro, sem a atenção aos direitos coletivos.

\section{Aspectos jurídicos das micro e pequenas empresas que são objeto de estudo do programa ALI}

As micro e pequenas empresas possuem exatamente a mesma natureza jurídica das demais empresas, independentemente de seu tipo social ou da forma de seu registro em Órgãos Comerciais ou Cartórios registrários. Todas as atividades, exercidas por meio de sociedades empresarias ou sociedades simples, são protegidas pelo direito que outorga determinadas vantagens competitivas e desburocratizadoras aos pequenos empreendimentos como se observará. Estas possuem clara função social, independente de sua expressão ou objetivo macro econômico.

Conceitualmente, a definição de micro e pequena empresa, assumiu por força legislativa, um caráter meramente econômico previsto na denominada Lei Geral para Micro e Pequenas Empresas ${ }^{1}$. De acordo com essa lei, que foi promulgada em dezembro de 2006 e atualizada pela Lei Complementar $n^{\circ} 147 / 2014$, as microempresas são as que possuem um faturamento anual de, no máximo R\$ 360 mil por ano. As pequenas devem faturar entre R\$ $360.000,01$ e $\mathrm{R} \$ 4,8$ milhões anualmente para ser enquadradas.

\footnotetext{
${ }^{1}$ Art. 3을 Para os efeitos desta Lei Complementar, consideram-se microempresas ou empresas de pequeno porte, a sociedade empresária, a sociedade simples, a empresa individual de responsabilidade limitada e o empresário a que se refere o art. 966 da Lei $n^{0} 10.406$, de 10 de janeiro de 2002 (Código Civil), devidamente registrados no Registro de Empresas Mercantis ou no Registro Civil de Pessoas Jurídicas, conforme o caso, desde que:

I - no caso da microempresa, aufira, em cada ano-calendário, receita bruta igual ou inferior a $\mathrm{R} \$ 360.000,00$ (trezentos e sessenta mil reais); e

II - no caso de empresa de pequeno porte, aufira, em cada ano-calendário, receita bruta superior a R\$ 360.000,00 (trezentos e sessenta mil reais) e igual ouinferior a R\$ 4.800.000,00

(quatro milhões e oitocentos mil reais). (Redação dada pela Lei Complementar $n^{\circ}$ 155, de 2016)
} 
Há quem também apresente um critério voltado para o número de empregados. Nesta visão, as microempresas serão aquelas que empregam até 9 pessoas no caso do comércio e serviços, ou até 19 pessoas, no caso dos setores industriais ou de construção. Já as pequenas empresas são definidas como as que empregam de 10 a 49 pessoas. Este critério não atesta bem a força capacitativa da micro e pequena empresa e nem tampouco a possibilidade de a mesma se beneficiar de certas vantagens institucionais e legais, própria de seu porte específico.

A proteção legal destes modelos empresariais, encontra-se primariamente no Art. 170 da Constituição Federal que ao tratar da ordem econômica, conforme os ditames da justiça social, observa entre os princípio o contido no inciso IX com a previsão de tratamento favorecido para as empresas de pequeno porte.

A outro lado, o Art. 179 da Constituição Federal faz expressa previsão no sentido de que a União, os Estados, o Distrito Federal e os Municípios dispensarão às microempresas e às empresas de pequeno porte um tratamento jurídico diferenciado, visando a incentivá-las pela simplificação de suas obrigações ou pela eliminação ou redução destas por meio de lei. Já o Art. 146 da Carta Magna expressou no inciso III que caberia à lei complementar estabelecer normas gerais em matéria de legislação tributária, especialmente sobre: d) definição de tratamento diferenciado e favorecido para as microempresas e para as empresas de pequeno porte, inclusive regimes especiais ou simplificados.

E foi através da Lei Complementar 123/2006, também conhecida como Lei Geral da Micro e Pequena Empresa (MPE) que seinstitui um tratamento simplificado, diferenciado e favorecido para as MPE, gerando ao poder público municipal um papel crucial, como agente de promoção de um ambiente favorável para fomentar o fortalecimento e a competitividade dos pequenos negócios.

Esta Lei Complementar estabeleceu normas gerais relativas ao tratamento diferenciado e favorecido a ser dispensado às microempresas e empresas de pequeno porte no âmbito dos Poderes da União, dos Estados, do Distrito Federal e dos Municípios.

Observe-se que este tratamento diferenciado e favorecido refere-se entre outros temas $\mathrm{a}:$

I - à apuração e recolhimento dos impostos e contribuições da União, dos Estados, do Distrito Federal e dos Municípios, mediante regime único de arrecadação, inclusive obrigações acessórias;

II - ao cumprimento de obrigações trabalhistas e previdenciárias, inclusive obrigações acessórias; 
III - ao acesso a crédito e ao mercado, inclusive quanto à preferência nas aquisições de bens e serviços pelos Poderes Públicos, à tecnologia, ao associativismo e às regras de inclusão.

IV - ao cadastro nacional único de contribuintes a que se refere o inciso IV do parágrafo único do Art. 146, in fine, da Constituição Federal.

E é no âmbito da colaboração para o implemento das políticas públicas que o Sebrae tem gerado ferramentas e programas ativos como o de Agente Local de Inovação.

\section{Aspectos econômicos das micro e pequenas empresas}

Dentre estas políticas públicas, tem relevo a iniciativa de promulgação da Lei 12.792/2013 que dispõe sobre a criação da Secretaria da Micro e Pequena Empresa.

Como órgão de assessoria direta à presidência da República, especialmente na formulação, coordenação e articulação de políticas e diretrizes para o apoio à microempresa, empresa de pequeno porte e artesanato e de fortalecimento, expansão e formalização de MPE; programas de incentivo e promoção de arranjos produtivos locais relacionados às microempresas e empresas de pequeno porte e de promoção do desenvolvimento da produção; programas e ações de qualificação e extensão empresarial voltados à microempresa, empresa de pequeno porte e artesanato; e programas de promoção da competitividade e inovação voltados à microempresa e empresa de pequeno porte;

Observa-se que na articulação e incentivo à participação da microempresa, empresa de pequeno porte e artesanato nas exportações brasileiras de bens e serviços e na sua internacionalização a Secretaria da Micro e Pequena Empresa participará na formulação de políticas voltadas ao microempreendedorismo e ao microcrédito, exercendo suas competências em articulação com os demais órgãos da administração pública federal, em especial com os Ministérios do Desenvolvimento, Indústria e Comércio Exterior, da Fazenda, da Ciência, Tecnologia e Inovação e do Trabalho e Emprego

Para que se possa observar a importância das micro e pequenas empresas no pais, pode-se visualizar os dados disponibilizados pelo Sebrae 2 šque demonstram que as MPE geraram, em 2011, 27,0\% do valor adicionado do conjunto de atividades pesquisadas (PIB).

2 Coletados nas obras Participação das Micro e Pequenas Empresas na Economia Brasileira, publicada pelo SEBRAE- Serviço Brasileiro de Apoio às Micro e Pequenas Empresas em Julho de 2014 e fevereiro de 2015 
Segundo o Sebrae, š esse percentual vem aumentando na série histórica, iniciada em 1985, quando esse indicador representava de $21,0 \%$ do valor adicionado (PIB), e em 2001, $23,2 \%$.

Nesta perspectiva, os serviços e comércio representaram, em 2011, 19\% do valor adicionado, enquanto a indústria totalizava 7,8\%; š Em relação ao número de empresas as MPE representaram, em 2011, nas atividades de serviços e de comércio, respectivamente, 98\% e 99\% do total de empresas formalizadas; $\check{s}$

No tocante ao emprego, as MPE representavam 44\% dos empregos formais em serviços, e aproximadamente $70 \%$ dos empregos gerados no comércio; š Cerca de $50 \%$ das remunerações do setor formal de comércio foram pagas, em 2011, por MPE.

Ainda, dos dados coletados, pode-se verificar que no período de 2009 a 2011, o valor agregado das MPE na economia nacional cresceu de R \$ 445 bilhões para R $\$ 599$ bilhões. O Sebrae estima que nos anos de 2012 e 2013, esses valores tenham sido, respectivamente, de R\$ 631 bilhões e R\$ 696 bilhões a demonstrar um crescimento contínuo desses valores, representando um crescimento médio anual de $11 \%$ a valores nominais

As Micro e Pequenas Empresas são de importância no quesito de geração de renda, emprego e remunerações. A diferença dessa importância entre Regiões e Estados está associada a própria importância de cada Região e Estados em termos da economia nacional. Mas, quando se compara a importância das MPE em termos da própria Região ou Estado fica evidente sua relevância em todas as variáveis estudadas pelo Sebrae.

No período 2009-2011 as MPE, tiveram grande impacto no pais. No setor de Serviços,geraram 36,3\% do total do Valor Adicionado das atividades com MPE do setor; representavam 98,1\% do número de empresas; empregaram 43,5\% dos trabalhadores; e pagaram $27,8 \%$ das remunerações de empregados no período.

No setor de Comércio, as MPE geraram 53,4\% do total do Valor Adicionado do setor; representavam 99,2\% do número de empresas; empregaram 69,5\% do pessoal ocupado no setor; e pagaram 49,7\% das remunerações dos empregados do setor no período.

No setor Industrial, as MPE geraram 22,5\% do Valor Adicionado do setor; representavam $95,5 \%$ do número de empresas; empregaram $42 \%$ do pessoal ocupado no setor; e pagaram $25,7 \%$ das remunerações de empregados no período, segundo os dados coletados pelo Sebrae.

A contribuição do Sebrae para esse desempenho tem sido fundamental, através de incentivos e treinamento para que os empreendedores formalizem suas atividades, o que lhes 
possibilita enormes vantagens em termos de acesso a crédito e acesso a mercados que não estão disponíveis para empreendimentos informais

\section{A utilização do Radar de Inovação no âmbito do programa ALI}

Segundo o disposto no Art. 64 da Lei Complementar de Micro e pequenas empresas, considera-se Inovação: a concepção de um novo produto ou processo de fabricação, bem como a agregação de novas funcionalidades ou características ao produto ou processo que implique melhorias incrementais e efetivo ganho de qualidade ou produtividade, resultando em maior competitividade no mercado. Criou-se a Instituição Científica e Tecnológica - ICT como órgão ou entidade da administração pública que tenha por missão institucional, dentre outras, executar atividades de pesquisa básica ou aplicada de caráter científico ou tecnológico.

Um núcleo de inovação tecnológica trata-se, segundo a lei, de um núcleo ou órgão constituído por uma ou mais ICT com a finalidade de gerir sua política de inovação e, qualquer serviço disponibilizado presencialmente ou na internet que possibilite acesso a informações, orientações, bancos de dados de soluções de informações, respostas técnicas, pesquisas e atividades de apoio complementar desenvolvidas pelas instituições é visto como um instrumento de apoio tecnológico para a inovação.

Como forma de apoio à inovação, preconiza o Art. 65 da lei Complementar que a União, os Estados, o Distrito Federal e os Municípios, e as respectivas agências de fomento, as ICT, os núcleos de inovação tecnológica e as instituições de apoio manterão programas específicos para as microempresas e para as empresas de pequeno porte, inclusive quando estas revestirem a forma de incubadoras, observando-se tanto as condições de acesso serão diferenciadas, favorecidas e simplificadas como o montante disponível e suas condições de acesso deverão ser expressos nos respectivos orçamentos e amplamente divulgados.

Inovação é uma ferramenta facilitadora do empreendedorismo e, segundo o Manual de Oslo, inovação é: [...] a implementação de um produto (bem ou serviço) novo ou significativamente melhorado, ou um novo processo, ou um novo método de marketing, ou um novo método organizacional nas práticas de negócios, na organização do local de trabalho ou nas relações externas (OCDE; FINEP, 2005).

Para a realização do diagnóstico e mensurar o grau de inovação, os Alis se utilizam do Radar da Inovação que gera um tipo de medição que ao demonstrar pontos fortes e pontos a serem trabalhados pelo empresário, sugere um plano de ação com soluções criativas para serem desenvolvidas no âmbito de um planejamento sistêmico. 
O Radar de Inovação é assim, uma metodologia desenvolvida a partir de estudos de Mohanbir Sawhney, diretor do Center for Research in Technology \& Innovation da KellogSchool of Manegement, Illinois,EUA a partir de quatro dimensões principais quais sejam: ofertas criadas; clientes atendidos; processos empregados e locais de presença usados.

A metodologia é apropriada para mensurar o grau de maturidade no uso do processo de gestão da inovação em empresas de pequeno porte. A partir da aplicabilidade de um questionário onde são atribuídas notas de 1 a 5 , verifica-se o grau de inovação nas dimensões relacionadas à oferta (que se refere aos produtos, bens e serviços ofertados no mercado), Marca., Plataforma, Soluções, clientes, relacionamento, agregação de valor, processos, organização, cadeia de fornecimento, presença, Rede e ambiência inovadora.

Um gráfico é elaborado com o concurso dos Alis e a partir destes resultados, considerando-se que a empresa que obtiver nota 5 em todas as dimensões propostas, será uma empresa inovadora. Uma nota 3 mostra um nível de inovação razoável, mas precisa de melhorias haja vista que não há sistematização do processo. Já as empresas que atingem ao final da avaliação a nota 1 , demonstram que a cultura da inovação não faz parte da sua realidade empresarial conservadora. Exemplo:

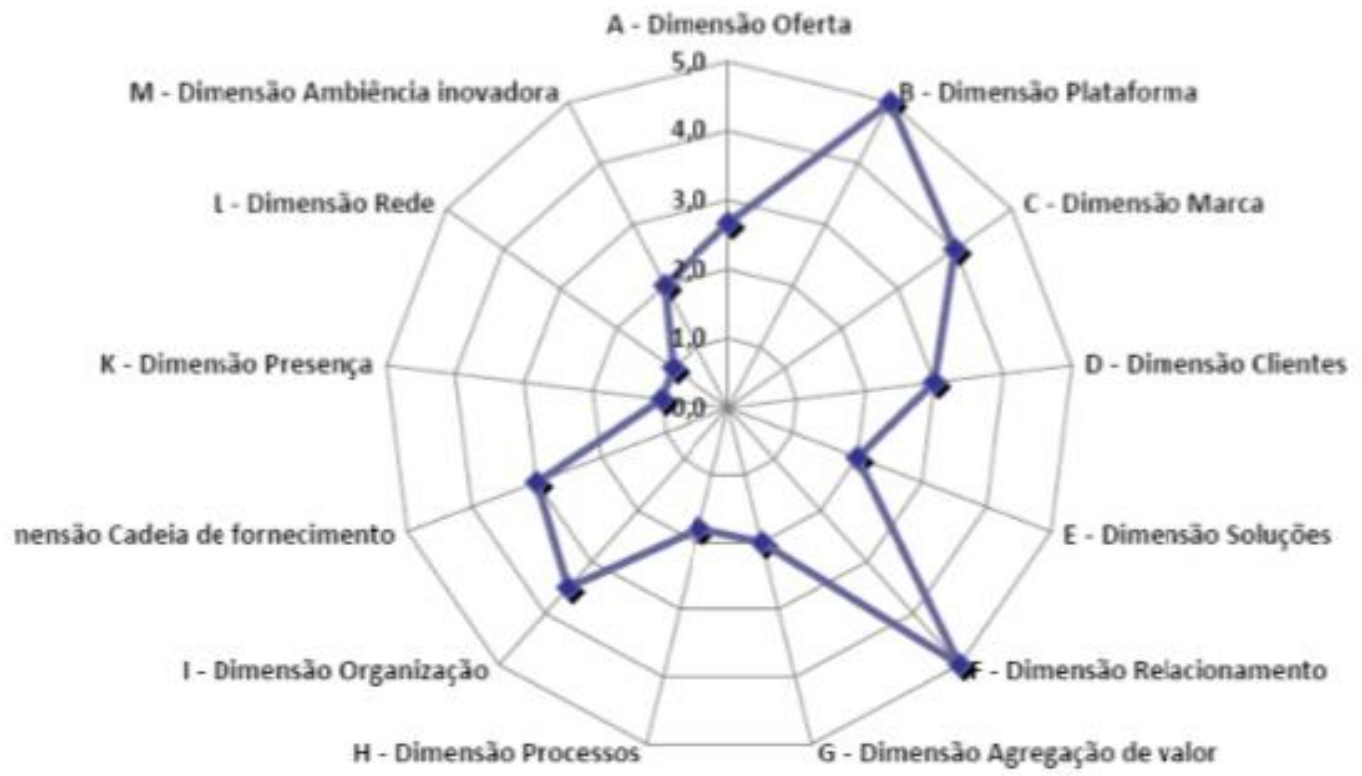

Fonte: Bachmann\& Associados

Após a análise dos dados do gráfico, é possível determinar o grau de inovação em cada dimensão e grau de inovação global de cada empresa. A partir deste resultado o agente local de inovação constrói junto ao empresário a matriz SWOT (Strenghts- forças ,Weaknessesfraquezas,Opportunities- oportunidades e Threats-ameaças) de sua empresa, que como uma 
importante ferramenta de análise voltada para o planejamernto estratégico empresarial, abrange os aspectos externos e internos que afetam a organização e com isto, há subsídios para gerar ações para aumentar a cultura de inovação para a organização.

Uma série de ações são recomendadas aos empresários para que possam modificar os resultados apresentados no Radar da Inovação e o Sebrae possui condições de viabilizar o treinamento específico, independente do setor. Como os resultados da implementação de um processo de inovação são demorados, observa-se a necessidade de se acompanhar temporalmente as empresas por um período de três anos

Muito embora especificamente o Radar de Inovação não trate da temática atual de sustentabilidade nas relações empresariais e ambientais, não se pode desprezar o fato de que nas dimensões voltadas para a oferta e processos existem itens específicos acerca desta matéria , notadamente na resposta ao meio ambiente e nos aspectos ambientais e de gestão de resíduos avaliados.

Enfim, de grande valia a contribuição Ali para a busca das métricas desejáveis no âmbito do Radar de Inovação, para o desenvolvimento sustentável da atividade empresarial voltada para as pequenas empresas.

\section{Os resultados obtidos na edição finalizada em 2017 do Programa ALI.}

Em 2017 foi finalizado o $3^{\circ}$ ciclo do Programa ALI no Estado de São Paulo que foi iniciado em julho de 2015, com excelentes resultados que podem ser assim sintetizados:

Empresas atendidas: Volume máximo - 17.357.

Dos 426 Agentes Locais de Inovação Cadastrados, 271 finalizaram o programa;

Receita gerada pelas empresas clientes no período de 30 meses $-\mathrm{R} \$ 4.600 .000,00$

Orientadores. 22 orientadores bolsistas, com titulações mínimas de Mestres ou Doutores.

Artigos elaborados. 383 artigos sobre os segmentos atendidos pelos ALIS.

Estudos de Caso elaborados. 332 estudos de casos sobre empresas com os melhores resultados obtidos.

Evolução do Radar Inovação : +49\% de aumento entre R0 e R3;

Evolução do Radar de Gestão +73 \% de aumento entre R0 e R3.

Pesquisa de impacto e satisfação: 8,4 - nota de satisfação com o programa na média nacional e 8,8 nota de satisfação com o programa ALI -Sebrae -SP. 
Pesquisa de aplicabilidade. 7,0 Nota de aplicabilidade nacional. 7,5 Nota de aplicabilidade do Programa ALI -Sebrae SP.

Pesquisa de resultados finalísticos. 50\% relatam a contribuição do programa para a redução de custos empresariais. 44\% relatam a contribuição do programa para o aumento da lucratividade da empresa.

Observa-se assim, a excelência do programa e a necessidade de incentivo constante para que possa o mesmo crescer qualitativamente e quantitativamente em prol de uma sociedade mais justa e competitiva sem que se possa afastar da construção dos valores morais e éticos empresariais.

\section{Considerações finais}

A conexão entre as aspirações de nova empresarialidade e as ferramentas desenvolvidas para a busca da continua inovação, tanto no campo de produtos e processo, como no fator organizacional e voltado para o marketing, se faz sentir quando se verifica os trabalhos de campo dos Agentes Locais de Inovação.

Uma conduta ética empresarial por parte daqueles que possam ingressar no projeto ALI, possivelmente será ressentida de forma positiva pelos consumidores haja vista que serão os destinatários diretos dos produtos ou serviços ofertados, gerando a possibilidade do desenvolvimento da responsividade social.

O cuidado com a clientela na busca da inovação, gerando pelo Programa Ali, e a atenção na percepção de suas necessidades reais e anseios, trará bons reflexos e realce na proatividade empresarial e, além de não significar um custo demasiado, poderá refletir positivamente no faturamento e lucratividade.

A partir da implantação do Programa ALI por meio do convenio entre o Sebrae e o CNPQ, criou-se ferramentas que contribuem sobremaneira para que se possa gerar no segmento das pequenas empresas, a ambiência inovadora necessária para buscar crescimento sustentável e produtividade, com resultados na perenização das mesmas.

Neste ponto, a nova empresarialidade como um dos ideários comportamentais a serem buscados com vistas a implantação de uma ética empresarial e apoio às políticas de responsabilidade social, pode também ser objeto de implementação e ser orientada a partir da realização de diagnóstico que possa mensurar o grau de inovação da empresa com o concurso de metodologia ativa adotada pelo Sebrae e transmitida aos Agentes de inovação a nível nacional. 
A metodologia desenvolvida para o Radar de Inovação a partir de quatro dimensões principais voltadas para as ofertas, clientes atendidos, processos empregados e locais de presença pode assim ser verificada sem desprezo da adoção posturas voltadas para a nova empresarialidade que revestem a atividade empresarial com padrões e valores éticos, sem que se afaste da busca pelo lucro como fator principal de sua existência.

Esta metodologia e a aplicação das dimensões estabelecidas no Radar da Inovação são apropriadas para mensurar o grau de maturidade empresarial e estes instrumentos, aliados a um comprometimento com os valores éticos e morais onde se possa dar atenção aos atores internos e externos relacionados à atividade empresarial, como os colaboradores, prestadores, clientes consumidores, fornecedores, sócios e órgãos de gestão, parece-nos que possibilitarão um valor agregado consistente da idealização de uma empresa solidária e colaborativa, contribuindo para um ambiente harmônico e estruturado que auxiliará no crescimento da nação.

\section{Referências bibliográficas}

CONSELHO NACIONAL DA INDÚSTRIA. Lei geral. Observatório da lei geral da micro e pequena empresa. Disponível em: http://www.leigeral.com.br/portal/main.jsp

DAVID, D.E.H.; CARVALHO, H.G.; PENTEADO, R.S. Gestão de Ideias. Curitiba: Editora Aymará, 2011.

GRECO, S.M.S.S, MACEDO, M.M.M et al. Empreendedorismo no Brasil: 2012. Curitiba: IBPQ,2012.

KOTLER, P.; ARMSTRONG, G. Administração de marketing: análise. Planejamento, administração implementação e controle. São Paulo: Atlas, 2007

MANUAL DE OSLO: Diretrizes para a coleta e interpretação de dados sobre inovação. OCDE Ministério da Ciência e Tecnologia. $3^{\mathrm{a}}$.ed., 2005. Disponível em: $<$ http://www.mct. gov.br/index.php/content/view/4639.html> Acesso em: out. 2017.

SEBRAE. Pesquisa GEM: empreendedorismo no Brasil e no mundo. Disponível em: http:/www.sebrae.com.br/customizado/estudos-e-pesquisas/temasestrategicos/empreendedorismo. 
SEBRAE. Participação das Micro e Pequenas Empresas na Economia Brasileira: Relatório Executivo. Brasília: SEBRAE, 2015.

SEBRAE. Guia para a inovação.Instrumento para a melhoria das dimensões da inovação, $2^{\mathrm{a}}$ Ed. Curitiba:SK Editora,2015.

SEBRAE.Gestão da empresa de pequeno porte.Brasília:Sebrae,2015.

SEBRAE.Manual operacional para o orientador do programa Ali.Brasília:Sebrae,2016.

SEBRAE. Inovação na empresa de pequeno porte. Brasília:Sebrae, 2015.

SIMÃO FILHO.Adalberto et PEREIRA.Sergio Luiz. A empresa ética em ambiente ecoeconomico. A contribuição da empresa e da tecnologia da automação para um desenvolvimento sustentável inclusivo. São Paulo: QuartierLatin, 2014.

SOARES.José Carlos Tinoco. Concorrência desleal vs. "tradedress" e/ou "conjuntoimagem". São Paulo: House, 2.004, pág.213 


\title{
A EQUIVOCADA APLICAÇÃO DO PRINCÍPIO DE PRESERVAÇÃO DA EMPRESA COMO FUNDAMENTO DE EXTINÇÃO DE PEDIDOS DE FALÊNCIA: ALGUMAS HIPÓTESES JURISPRUDENCIAIS.
}

\author{
Rafael Peteffi da Silva \\ Universidade Federal de Santa Catarina \\ Adriana Santos Rammê \\ Faculdade CESUSC
}

\begin{abstract}
Resumo
O presente artigo trata da aplicação do princípio da preservação da empresa como fundamento para extinção de pedidos de falência feitos com preenchimento dos requisitos legais. Analisase, a partir do método dedutivo, com técnica de pesquisa bicliográfica, os reflexos econômicos decorrentes dos modelos falimentar e recuperatórios instituídos pela legislação, bem como os fundamentos axiológicos que diferenciam cada um dos institutos. Demonstra-se a presença da axiologia preservacionista nas regras próprias da falência e aponta-se as razões pelas quais se entende equivocadas algumas decisões judiciais que afastam os pedidos de falência fundados na regra do artigo 94, inc. I da Lei 11.101/05 com base numa invocação abstrata do princípio da preservação da empresa.
\end{abstract}

Palavras-chave: preservação da empresa, falência, extinção do pedido, axiologia.

\section{Abstract/Resumen/Résumé}

This research departs from the application of the principle of preservation of the enterprise as a basis for terminating bankruptcy petitions made with fulfillment of legal requirements. From the deductive method, with bicliographic research technique, the economic reflexes arising from the bankruptcy and recuperatory models instituted by the legislation, as well as the axiological foundations that differentiate each of the institutes. Presence of the preservationist axiology in the proper rules of bankruptcy is demonstrated and the reasons for which are considered mistaken some judicial decisions that distance the applications of bankruptcy based on the rule of article 94, inc. I of Law 11.101 / 05 based on an abstract invocation of the principle of the preservation of the company. 
Keywords/Palabras-claves/Mots-clés: preservation of the enterprise, banckrupcy, extinction of the request, axiology.

\section{Introdução}

O presente artigo versa sobre a aplicação do princípio da preservação da empresa no caso de pedidos de falência apresentados por credores com base na regra expressa do artigo 94, inc I da Lei 11.101/05 - LRF. Utilizar-se-á um acórdão da Terceira Câmara de Direito Comercial do Tribunal de Justiça de Santa Catarina - TJSC, do ano de 2016, apenas como modelo ilustrativo da argumentação que vem sendo utilizada em outros tantos julgados e decisões de primeiro grau para afastar a legitimidade do credor para apresentar pedido de falência, mesmo tendo sido preenchidos todos os requisitos exigidos pelo ordenamento jurídico.

É assente que a Lei 11.101/05 rompeu com o paradigma liquidatório-solutório do Dec.Lei 7.661/45, incorporando em seus regramentos o espírito preservacionista como corolário do princípio da função social da empresa, tendo como principal objetivo viabilizar a superação do estado de crise econômico-financeira das empresas.

Ocorre que o princípio da preservação da empresa foi o fundamento da reforma da legislação falimentar, de modo que coube ao legislador, observando o modelo ideológico/ político/econômico do ordenamento jurídico brasileiro, concretizar, por meio das regras dispostas na Lei 11.101/05 a incidência de tal princípio.

Foi, portanto, nessa perspectiva que o legislador instituiu os modelos recuperatórios (recuperação judicial, recuperação extrajudicial e recuperação especial para micro e pequenas empresas) e limitou, com mais rigor, a possibilidade dos credores apresentarem pedidos de falência, instituindo o modelo de presunção de insolvência com exigências formais mais rigorosas do que as previstas no Dec.Lei 7.661/45.

No entanto, apesar de tal princípio ser de relevância impar para a compreensão do relevante papel da empresa para o desenvolvimento econômico do país, com a geração de emprego e renda e de recursos para que o Estado possa cumprir com seus desígnios sociais, seu sentido não deve ser superdimencionado a ponto de provocar o banimento e a desconsideração da relevância do direito de crédito na vida de todas as empresas e no mercado econômico.

O problema que se propõe enfrentar refere-se à inadequação da aplicação do princípio da preservação da empresa para afastar a legitimidade do credor a apresentar pedido de falência 
quando reunir os elementos formais da regra contida no art. 94, inc. I da Lei 11.101/05. O objetivo é contribuir com elementos teóricos para uma melhor aplicação do aludido princípio no âmbito exclusivo do instituto falimentar, apontando as conseqüências nefastas da negativa de recebimento de pedidos de falência apresentados por credores que reúnam os elementos legais sob o argumento da necessidade de se preservar as empresas, evitando-se a todo o custo o decreto de quebra.

Parte-se da hipótese de que a ampla propagação da mudança do paradigma legislativo para incorporar o princípio da preservação da empresa na concepção da lei de falências de 2005 tem levado alguns operadores do direito a desconsiderar dois pontos importantes: os fundamentos justificadores da existência do instituto da falência e os reflexos econômicos de todo o sistema falimentar. Assim, aponta-se o surgimento de um equivocado entendimento de que compete ao intérprete/aplicador da lei evitar a todo custo a decretação de falências com o genérico argumento de que a empresa exerce uma função social e, por isso, precisa ser preservada.

Assim, o segundo tópico do trabalho será destinado à consolidação de algumas premissas básicas que envolvem a legislação falimentar, ou seja, seus reflexos econômicos e os diferentes fundamentos axiológicos dos institutos falimentar e recuperatórios. A seguir, o estudo passa a demonstrar que a axiologia preservacionista já está contida em diversas regras específicas ligadas ao instituto da falência, inclusive no conteúdo do inciso I do art. 94 da LRF. Por fim, no quarto tópico serão analisados os fundamentos da decisão escolhida como paradigmática, apontando-se em que medida se entende haver uma equivocada interpretação da incidência do princípio da preservação da empresa como limitador da regra que regula o pedido de falência.

\section{Os reflexos econômicos e os fundamentos axiológicos da legislação falimentar}

Do ponto de vista econômico, a existência da legislação falimentar decorre do reconhecimento de que na vida das empresas é normal que ocorram situações de insolvabilidade, ${ }^{1}$ sendo necessário o estabelecimento de condições adequadas para a

\footnotetext{
${ }^{1}$ Klênio Barbosa e outros (2017) apontam que num cenário ideal de total pagamento das dívidas, a legislação falimentar não seria necessária, destacando que "No entanto, não é isso que ocorre na prática, nem é o que a teoria econômica prevê. A necessidade de uma legislação falimentar fica mais evidente quando é apresentado o problema de coordenação que envolve empresa e credores. Na ausência de uma legislação, o problema de coordenação pode gerar um exemplo de profecia autorrealizável (Jackson 2001, White 2005). Os credores podem identificar os problemas financeiros que atingem a empresa, antecipar a possibilidade futura de insolvência e, agindo de forma individual, cada credor pode escolher a estratégia de retirar parte dos ativos da empresa como forma de se proteger
} 
composição dos múltiplos interesses que convergem diante de uma situação de falta de pagamento: i. dos credores individualmente; ii. o do mercado ${ }^{2}$ de crédito; iii. o dos empregados da empresa devedora; iv. o do Estado, na função de arrecadador de tributos e de implementador de desenvolvimento nacional.

Ricardo Negrão (2016, p. 246) identifica a relação do Direito Falimentar com os diversos ramos do direito e também com a economia, citando, quanto a essa última, as clássicas palavras de Carvalho de Mendonça para ressaltar que "apreciada economicamente, a falência interessa não somente à economia individual como à publica, pois incontestavelmente perturba o crédito público, produz dispersão de capitais, trazendo dano para a economia geral”.

Nem sempre é fácil fazer a intersecção do direito concursal com a economia. Daniel Truffat (2008) aponta a existência de correntes teóricas, que ele denomina de "políticas negatórias", que parecem acreditar que as soluções concursais (recuperatórias ou falenciais) são um problema e que a economia ficaria melhor se se suprimisse a legislação falimentar. ${ }^{3} \mathrm{~A}$ despeito de ressaltar a importância dos remédios recuperatorios, focados na preservação da empresa, o autor não deixa de apontar, também, a relevante função do regramento da falência, vez que a supressão do concurso falimentar acentuaria "La guerra de todos contra todos (con la obvia victoria de los mas fuertes”. (TRUFFAT, 2008, p. 291)

A legislação falimentar, assim como o intérprete/aplicador, deve levar em conta os reflexos econômicos da falta de balanceamento entre os direitos de credores e devedores, pois uma legislação excessivamente benéfica aos credores pode não contribuir para manutenção das atividades econômicas em crise circunstancial, mas uma lei eminentemente favorável aos devedores pode reduzir drasticamente o volume de crédito e/ou aumentar o valor do custo do

\footnotetext{
de um prejuízo maior com a decretação da falência da empresa. Agindo de forma racional, os credores geram uma corrida para a retirada dos ativos, provocando uma prematura liquidação do negócio. A existência de uma legislação falimentar tem por objetivo corrigir o problema de coordenação. Do ponto de vista econômico, a legislação falimentar cria as condições para que situações de insolvência financeira tenham soluções previsíveis, céleres e transparentes, de modo que os ativos tangíveis e intangíveis sejam preservados e o negócio não seja interrompido, de tal forma que a insolvência gere problemas menores para a economia como um todo (Hotchkiss et al. 2008, von Thadden et al. 2010).” (BARBOSA et al, 2017, p. 475).

${ }^{2}$ Refere-se a mercado como uma instituição jurídica composta por agentes (agentes do mercado) que se relacionam por meio de comportamentos regulados, ou melhor, como uma ordem "no sentido de regularidade e previsibilidade de comportamentos, cujo funcionamento pressupõe a obediência, pelos agentes que nele atuam, de determinadas condutas." (GRAU, 2010, p. 28).

3 "Las políticas 'negatorias' pueden no ser extremistas, pero ir haciendo camino. Em iun fallo reciente de primera instancia - hoy recurrido - en el concurso de la Union Argentina de Rugby se puso tanto énfasis en 'lo excepcional' Del tramite concursal, que podría pensarse en algún paso, em esse sentido (en el sentido negatorio)." (TRUFFAT, 2008, p. 291).
} 
financiamento das atividades, o que, por via transversa, pode culminar prejudicando aqueles a quem se pretendia ajudar. ${ }^{4}$

Em estudo desenvolvido sobe o impacto da lei de falência no mercado de crédito, os autores Klênio Barbosa, André Carneiro, Regis A. Ely e Felipe Garcia Ribeiro (2017) acentuam a necessidade de se balancear os direitos dos credores e dos devedores, sob pena de uma legislação eminentemente benéfica ao devedor servir apenas para adiar pedidos de falências e elevar o valor do financiamento das atividades:

Por outro lado, se a legislação for favorável ao devedor, tem-se a possibilidade de adiamento do pedido de falência (Povel 1999), mantendo em funcionamento empresas inviáveis, e favorecendo excessivamente as empresas devedoras. Nesse cenário, a dificuldade em executar garantias reduz o ganho esperado pelos credores em caso de insolvência da empresa, elevando a taxa de financiamento e reduzindo o volume de crédito no mercado (Djankov et al. 2008). Dessa forma, uma lei de falência deve balancear os direitos de credores e devedores alocando de maneira eficiente os riscos que envolvem o negócio da empresa e a concessão de financiamento (Lisboa et al. 2005) (BARBOSA, et al, 2017, p. 476)

Nesse sentido, assim como o legislador deve equilibrar os interesses em jogo numa situação de crise econômica das empresas, também o intérprete, na aplicação das normas ao caso concreto, não pode perder de vista os dois lados protegidos/interessados numa situação de incapacidade de pagamentos ${ }^{5}$, sob pena de prejudicar a eficiência da legislação falimentar.

Ademais, a par da atenção aos impactos econômicos da legislação falimentar, o intérprete/aplicador também deve considerar os fundamentos axiológicos, ou seja, os valores que justificam e sustentam o sistema legislativo de tratamento da situação de crise econômicofinanceira das empresas.

Em respeito aos diversos interesses envolvidos na dinâmica empresarial, as legislações falimentares ocidentais, ligadas tanto ao sistema da Common Law, quanto ao sistema da Civil Law ${ }^{6}$, possuem dois grandes eixos de tratamento da situação de crise econômico-financeira das

\footnotetext{
${ }^{4}$ Maria Rosa Longone (2008) analisa os elementos que potencializam a eficiência dos sistemas legais de insolvência, destacando que a eficiência se dá quando se consegue ao mesmo tempo maximizar o pagamento do credor e ao mesmo tempo minimizar o risco moral do devedor. Assim, sugere, dentre inúmeras medidas, o respeito dois preceitos fundamentais: i) "las reglas para que los acreedores (presunciones de insolvencia) y el deudor (requisitos de admisión) soliciten la iniciación del proceso son claras, pocas y flexibles; ii) se disponen medidas pre-concursales de prevención de la insolvência”. (LONGONE, 2008, p. 253)

${ }_{5}^{5}$ No sentido da compatibilização dos interesses públicos e privados que coexistem no âmbito da empresa moderna, Marta Zabaleta Díaz, em estudo sobre a evolução do princípio da conservação da empresa e sua incorporação pela Ley Concursal Espanhola Ley 22/2003 destaca que "Es en este contexto de armonización de las finalidades conservativas com La satisfacción preeminente de los interesses de los acreedores en el que debe analizarse da Ley Concursal espanola.” (ZABALETA DÍAZ, 2006. p. 31).

${ }^{6}$ Modelos falimentares e recuperatórios são encontrados tanto nos capítulos da Banckruptcy americana, quanto nas legislações dos países Europeus, como França, Itália, Espanha, Portugal, e Latino-Americanos como México,
} 
empresas, que se apresenta como a situação de interrupção ou falta de pagamentos. Cada um dos eixos possui sua justificativa axiológica de existência, mas ambos possuem um mesmo objetivo em comum: interromper o estado de falta de pagamento dos credores ${ }^{7}$.

Assim, atentas aos impactos econômicos da crise empresarial, tais legislações preveem, de um lado, a regulamentação de institutos preventivos, destinados à viabilizar a superação dos estados de crise, baseados na axiologia preservacionisata, e de outro, a regulamentação da hipótese falimentar de encerramento das atividades econômicas que não se mostrarem aptas à recuperação, baseada na par conditio creditorum.

Nesse contexto, o principio da preservação da empresa aparece, na Lei n. 11.101/05 LRF, como o valor axiológico ${ }^{8}$ justificador da existência/criação dos institutos recuperatórios ${ }^{9}$, o que implica dizer que o objetivo de busca pelo pagamento dos credores foi instrumentalizado pelo legislador de modo a promover, sempre que possível, o soerguimento da atividade.

Como se demonstrará, a axiologia preservacionista também refletiu, ainda que tangencialmente, na regulamentação do instituto da falência, mas não aboliu com seu fundamento próprio de existência ${ }^{10}$ : o princípio da par conditio creditorum como remédio ao nefasto efeito do "prior in tempore, prior in iure" ${ }^{11}$ produzido pelas execuções individuais.

Para Marcelo Gustavo Barreiro, o instituto da falência tem origem na insuficiência dos modelos de execução individuais diante da inadimplência generalizada, explicada com o exemplo da solução "Buffet":

Peru, Argentina e Uruguai. A existência de todos esses sistemas influenciou o legislador brasileiro a instituir os modelos recuperatórios pela Lei 11.101/05 (RAMMÊ, 2013, p.64-66).

${ }^{7}$ Nesse sentido, conferir Efrain Hugo Richard, para quem 'eliminar el estado de cesación de pagos resulta el bien jurídico tutelado' pelo sistema concursal. (RICHARD, 2010. p. 453).

${ }^{8}$ Tal princípio tem sua origem no princípio da garantia do desenvolvimento nacional, previsto nos artigos $3^{\circ}$, II, 23, X, 170, VII e VIII, 174, caput e § 1ํㅡ, e 192 da Constituição Federal. (TOMAZETTE, 2017, p. 53) No mesmo sentido, Adriana Ramme destaca que o princípio da preservação da empresa "ganha força como princípio constitucional ao ser extraído dos fundamentos e das finalidades da ordem econômica, notadamente a partir: i) da atribuição primordial à empresa privada do exercício de atividade econômica (decorrência da livre iniciativa), ii) da previsão de valorização do trabalho (refletida na busca do pleno emprego), iii) da vinculação da empresa a uma função social, e iv) da compreensão do papel da empresa privada para o desenvolvimento econômico do país". (RAMMÊ, 2013, p. 37-38)

${ }^{9}$ Ao lado da recuperação judicial, a LRF trata nos artigos 161-167 do modelo de Recuperação Extrajudicial e nos artigos 70-72 do modelo de Recuperação Judicial Especial para Micro e Pequenas Empresas.

${ }^{10}$ Marlon Tomazette explica não ser unânime o elenco dos princípios que fundamentam a legislação falimentar. No geral, os autores apresentam os princípios dos institutos recuperatórios e da falência, de maneira conjunta: "Elenise Peruzzo dos Santos indica como princípios a igualdade entre os credores, a celeridade, a publicidade, a preservação da empresa, a viabilidade e a maximização do valor dos ativos do falido. Também de forma genérica, Waldo Fazzio Júnior elenca como princípios do regime da insolvência do agente econômico o da viabilidade da empresa, da relevância dos interesses dos credores, da publicidade dos procedimentos, da par conditio creditorum, da maximização de ativos e da preservação da empresa. No mesmo caminho, Carlos Alberto Farracha de Castro elenca como princípios do direito falimentar a preservação do crédito, a igualdade de credores, a vedação ao enriquecimento ilícito, a preservação da empresa, a celeridade e a coletividade.” (TOMAZETTE, 2017, p. 282)

${ }^{11}$ Primeiro em tempo, primeiro em direito. 
El mecanismo darwiniano de que el primero en el tiempo es el mejor en el derecho hace agua por los cuatro costados en la situación de crisis o insolvencia generalizada, en donde aquel solo llevaría a lo que los colegas del Perú denominan la "solución bufete", en la que los primeros que llegan a sentarse a la mesa del deudor comerán (toda o parte de su deuda), y los menos avezados, los no avisados o, directamente, los mas pacientes estarán condenados a recibir migajas. El Derecho de la Insolvencia nace como reacción a la ley del más fuerte que importa dejar librado a los arbitrios individuales de cada acreedor la posibilidad de cobro ante la crisis generalizada de un sujeto deudor importa. (BARREIRO, 2017, p. 2)

Assim, a falência, como processo de execução coletiva, se funda no ideário de afastar as preferências que o tempo (ou a sorte) concede ao credor que conseguir chegar no patrimonio do devedor insolvente, deixando os credores posteriores sem qualquer possibilidade de recebimento, de modo que " fala-se em aplicação da par conditio creditorum, no sentido de que todos os credores terão direitos iguais no processo de falência, ressalvadas as preferências estabelecidas pela legislação". (TOMAZETTE, 2017, p. 282)

Conforme referido, embora os institutos recuperatórios e falimentar possuam fundamentos distintos, a preservação da empresa influenciou, também, a formação das normas referentes ao instituto falimentar, pois a hipótese de liquidação foi reestruturada - com imposição de critérios mais rígidos - a fim de se evitar o encerramento precipitado da atividade do devedor.

\section{Regras de incorporação da axiologia preservacionista pela LRF}

É certo que a axiologia preservacionista exurge como princípio justificador da existência e criação dos institutos recuperatórios ${ }^{12}$, mas ela foi incorporada à legislação por meio de regras definidoras de condições e parâmetros para se obter a manutenção da existência das empresas, e não como valor genérico e abstrato que se justifica como um fim em si mesmo.

A mais importante condição e a que mais interessa para a presente exposição é a prevista no inciso II do artigo 53 da Lei 11.101/05 que impõe que a empresa demonstre, em seu plano de recuperação, a sua viabilidade econômica. Em outras palavras, a empresa que merece utilizar a recuperação judicial e merece ser preservada por ser uma atividade geradora de

\footnotetext{
${ }^{12}$ Nesse sentido, o texto do artigo 47 da Lei 11.101/05 é claro ao inserir a promoção da preservação da empresa como finalidade da recuperação: Art. 47. A recuperação judicial tem por objetivo viabilizar a superação da situação de crise econômico-financeira do devedor, a fim de permitir a manutenção da fonte produtora, do emprego dos trabalhadores e dos interesses dos credores, promovendo, assim, a preservação da empresa, sua função social e o estímulo à atividade econômica.
} 
desenvolvimento econômico, fonte de trabalho e renda, é apenas e tão somente aquela que se mostrar economicamente viável e socialmente útil.

A viabilidade econômica da empresa, que justifique sua preservação, não é algo que possa ser inferido a partir de sua mera existência. Em outras palavras, não é porque a empresa existe que ela é economicamente viável e que merece, indiscriminadamente, a guarida judicial da preservação.

Marlon Tomazette (2017, p. 193) ressalta que "a recuperação judicial é um instituto aplicável apenas a empresas viáveis e, por isso, é essencial que o plano de recuperação demonstre a viabilidade econômica das medidas propostas." 13

A demonstração da viabilidade da atividade é, portanto, ônus da própria empresa e serve para convencer os credores ${ }^{14}$ de que "os sacrifícios que eles terão que fazer para permitir a superação da crise econômico-financeira serão compensados com benefícios futuros". (TOMAZETTE, 2017, p. 193)

Não se estabeleceu o instituto da recuperação judicial para salvar o “insalvavel”, já que a manutenção de uma empresa insolvente também provoca inúmeros efeitos danosos à economia. Desta forma, há que se perceber que a falência também atende a interesses da sociedade. (BORGARELLO, 2011)

É imperioso que a legislação falimentar estabeleça pressupostos objetivos para que as empresas possam utilizar os institutos recuperatórios, sob pena de torná-los uma panacéia sem efetividade

Porque si cualquiera que está ante un mero incumplimiento recurre al sistema para excepcionarse de pagar, y con ello resulta que no le paga a nadie e inicia un proceso de estas características, no tardaríamos más de dos o tres días en tener presentadas la inmensa mayoría de empresas que ha dejado de cumplir con una u otra obligaciones y si nadie le paga a nadie, el mismos riesgo de propagación sistémica de la insolvencia que se pretende evitar mediante el sistema excepcional de prevención de la quiebra, se haría realidad, haciendo colapsar la cadena de pagos y quebrando el sistema todo.

(DASSO, 2016, p. 202)

\footnotetext{
${ }^{13}$ No mesmo sentido, Dr. Miguel A. Raspall afirma que "La viabilidad de la empresa, no puede ser tomada como una mera enunciación vacía, declamativa o altisonante. Como ya nos hemos referido anteriormente, el principio de conservación de la empresa encuentra su límite en la viabilidad de la misma. De esto resulta, que no deben sostenerse a las empresas que no tienen capacidad para sanearse". (RASPALL, 2016. p. 90)

${ }^{14}$ BARBOSA, et al esclarece que "A rigor, empresas em situação de insolvência financeira, que possuam valor presente positivo do fluxo de caixa, demonstram capacidade de pagamento de suas dívidas e condições de recuperação econômica. Já empresas com situação de insolvência financeira e valor presente negativo do fluxo de caixa devem mudar o seu modelo de gestão e/ou o seu plano de negócios a fim de demonstrar para seus credores que uma renegociação das dívidas fornece um ganho esperado maior do que a liquidação de seus ativos. Caso contrário, essas empresas não têm justificativa econômica para continuarem operando." (BARBOSA, et al, 2017, p.476)
} 
Assim, mostra-se falacioso afirmar que sempre a preservação da empresa é o que de melhor se pode fazer para o desenvolvimento econômico e social. Aurelio Martínez, tecendo críticas à legislação espanhola quanto a uma aparente preferência à concessão dos convênios (equivalente recuperatório) elenca algumas hipóteses em que a falência (liquidación) pode se mostrar mais interessante para a sociedade do que a recuperação ${ }^{15}$ :

\begin{abstract}
(...) el legislador parece creer que la única forma de salvar una empresa es el convenio. Error. De hecho, es posible que la liquidación permita incrementar las posibilidades de salvación de la empresa, ya que se abre la posibilidad de que numerosos candidatos (y no sólo los antiguos dueños, que es lo que se promueve con el convenio) puedan concurrir al proceso de compraventa de la empresa. En tercer lugar, el legislador también parece creer que una empresa tiene un mayor valor en funcionamiento que en liquidación. Error. En ocasiones, empresas en funcionamiento tienen incluso un valor negativo (piénsese, por ejemplo, en un restaurante que ofrece una comida muy mala y, por este motivo, genera flujos de caja negativos) y, sin embargo, tienen cierto valor en liquidación, al poder obtener algún valor de la venta individual de sus activos (e.g. inmuebles, maquinaria, etc.). Incentivar el mantenimiento de este tipo de empresas, tal y como incentiva el legislador español, no sólo generará un coste para quienes financien la empresa (que, en situaciones de desbalance, serán íntegramente los acreedores) sino que también generará un coste de oportunidad para la sociedad en su conjunto, al impedir que, por ejemplo, un tercero adquiera el inmueble de este restaurante y abra una tienda de ropa que, quizás, sea todo un éxito, y hasta permita triplicar el tamaño de la empresa.(MARTÍNEZ, 2018)
\end{abstract}

Uma segunda condição de utilização do instituto da recuperação judicial que importa ser destacada é a regra contida no artigo 35 da $\mathrm{LRF}^{16}$ que concede aos credores (e não ao magistrado!) o poder de analisar e decidir sobre a real potencialidade e a conveniência da recuperação econômica da atividade por meio do plano apresentado. ${ }^{17}$ Trata-se de medida que evidencia a tentativa da legislação compatibilizar os interesses dos credores (prestigiando seu poder de análise e decisão) e da empresa devedora (permitindo-lhe apresentar propostas, negociar e provar sua viabilidade).

\footnotetext{
${ }^{15}$ Em outro estudo, o mesmo autor ainda vislumbra outras possibilidades : "De hecho, la liquidación o venta de los activos resultará una alternativa más deseable que la reorganización cuando: (i) el negocio sea inviable y, por tanto, el valor de los activos en funcionamiento resulte inferior que el valor de los activos en liquidación; y (ii) cuando el negocio (o la idea de negocio) sea viable pero, sin embargo, los acreedores no tengan confianza en la honestidad, capacidad o conocimiento de los antiguos socios/administradores, y exista la posibilidad de que un tercero con mayor credibilidad y mejores recursos pueda gestionar el negocio. En consecuencia, la solución ex post del Derecho concursal parece clara: promover la solución que consiga maximizar el valor de la empresa. De esta manera, no sólo existirán mayores posibilidades de que la empresa siga generando riqueza, trabajo y bienestar social, sino que, en la medida en que el valor de la empresa resulte mayor, también se incrementará el grado de satisfacción de los acreedores." (MARTINEZ, 2016, p. 51)

${ }^{16}$ Art. 35. A assembléia-geral de credores terá por atribuições deliberar sobre:

I - na recuperação judicial: a) aprovação, rejeição ou modificação do plano de recuperação judicial apresentado pelo devedor;

${ }^{17}$ Enunciado 46 da I Jornada de Direito Comercial do Conselho da Justiça Federal: "Não compete ao juiz deixar de conceder a recuperação judicial ou de homologar a extrajudicial com fundamento na análise econômicofinanceira do plano de recuperação aprovado pelos credores."
} 
Além disso, como afirmado alhures, apesar da axiliogia preservacionista ter servido de base para instituição dos modelos recuperatórios pela LRF, ela igualmente influenciou a regulamentação legal do instituto da falência, dando-lhe novos contornos, mas sem desnaturalizar seus fundamentos de existência. Nesse viés, o sistema de presunção de insolvência ${ }^{18}$ adotado pela legislação falimentar brasileira foi recrudescido, especiamente com a finalidade de evitar o desvituamento de sua utilização como mera ação de cobrança de pequenos valores.

Carlos Henrique Abrão (2016. p. 360) ressalta que o recrudescimento da norma que prevê a insolvência em razão da impontualidade, com a exigência da comprovação de dívida maior do que 40 salarios mínimos "teve o condão de moralizar o instituto da falência", fazer com que cessassem de imediato os ajuizamentos de pedidos por quantias pequenas. ${ }^{19}$

Importa ressaltar que a LRF não exige a demonstração de insolvência econômica com a comprovação efetiva do déficit patrimonial do devedor, até porque isso seria exigir do credor o impossível, já que ele não tem acesso aos documentos contábeis e informações sobre o valor do ativo e do passivo do devedor. Por isso, o legislador brasileiro optou por exigir do credor apenas a demonstração da insolvência jurídica do devedor que se extrai das hipóteses previstas em lei [e por isso, insolvencia presumida].

Identifica-se, portanto, na regra do art. 94, inc. I da LRF a finalidade preservacionista, uma vez que ela dificultou (sem impedir!) a caracterização do estado falimentar pela mera impontualidade, exigindo do credor a comprovação de uma impontualidade considerada grave. A gravidade, na definição do legislador, se caracteriza pela implementação de 2 critérios: 1) que a dívida, materializada em título ou títulos executivos vencidos, tenha ultrapassado a soma de 40 salários mínimos na data do pedido; 2) que o credor já tenha levado os títulos a protesto, oportunizando, novamente, à empresa devedora a amortização da dívida.

Entretanto, não somente neste, mas também em outros dispositivos ligados ao procedimento da falência, o legislador adequou o instituto à axiologia preservacionista. Assim, o artigo $98^{20}$ ampliou o prazo de defesa e possível depósito elisivo (para impedir a decretação

\footnotetext{
${ }^{18}$ Marlon Tomazette (2017, p. 303) explica que "o Brasil adotou um sistema misto de configuração da falência. Além da insolvência confessada pelo devedor, admite-se também a presunção de insolvência em razão da impontualidade injustificada, da execução frustrada ou da prática de atos de falência (Lei no 11.101/2005 - art. 94)."

${ }^{19} \mathrm{O}$ autor também elogia o agravamento da regra exposta, afirmando que "bem agiu o legislador ao normatizar o tema, criando com isso nova mentalidade, aberto o horizonte, salientando de maneira adequada importância compatível com o estado de insolvência e não simples impontualidade do devedor" (ABRÃO, 2016, p. 359)

${ }^{20}$ Art. 98. Citado, o devedor poderá apresentar contestação no prazo de 10 (dez) dias.

Parágrafo único. Nos pedidos baseados nos incisos I e II do caput do art. 94 desta Lei, o devedor poderá, no prazo da contestação, depositar o valor correspondente ao total do crédito, acrescido de correção monetária, juros e
} 
da falência), de $24 \mathrm{~h}$ para 10 dias, dando mais tempo para a empresa reunir o dinheiro necessário para pagamento da dívida, ou os elementos que comprovam sua relevante razão de direito para não realizar o pagamento. O artigo 96 , inc. VII $^{21}$ estabelece que a falência requerida com base no artigo 94, inc. I não será decretada se o devedor apresentar pedido de recuperação judicial no prazo da contestação, concedendo à empresa uma derradeira oportunidade de impedir a decretação da falência por meio da demonstração de intenção de recuperar-se. Por fim, o artigo 140 da LRF previu uma sistemática de liquidação mais eficiente dos ativos, priorizando a venda de seus estabelecimentos em bloco, buscando a maximização dos valores a serem obtidos no leilão e a conseqüente minimização das perdas dos credores, o que corrobora por reduzir os impactos econômicos da falência.

\section{Os equívocos na fundamentação dos acórdãos do TJSC}

Partindo-se dessas premissas conceituais, pode-se identificar, na decisão a seguir analisada, ${ }^{22}$ equívocos na fundamentação justificadora da aplicação do princípio da preservação da empresa para afastar a legitimidade de credores apresentarem pedido de falência, mesmo tendo preenchidos os requisitos legais, numa flagrante negativa de acesso ao uso do remédio processual adequado e garantido pela LRF.

Na apelação n. 0000854-49.2014.8.24.0037, a Terceira Câmara de Direito Comercial, em 17/11/2016, decidiu por unanimidade manter a sentença de primeiro grau que havia extinguido o processo falimentar por vício no protesto, embora por argumento diverso do utilizado em primeiro grau, apontando uma falta de interesse de agir. ${ }^{23}$

honorários advocatícios, hipótese em que a falência não será decretada e, caso julgado procedente o pedido de falência, o juiz ordenará o levantamento do valor pelo autor.

${ }^{21}$ Art. 96. A falência requerida com base no art. 94, inciso I do caput, desta Lei, não será decretada se o requerido provar: [...] VII - apresentação de pedido de recuperação judicial no prazo da contestação, observados os requisitos do art. 51 desta Lei;

${ }^{22}$ A decisão foi escolhida como ilustrativa de um posicionamento que vem sendo adotado por magistrados de primeiro grau nas Comarcas de SC e acatado em algumas Câmaras de Direito Comercial do TJSC, como se identifica também na apelação n. 0006490-84.2008.8.24.0011 da Segunda Câmara de Direito Comercial. Ainda, no julgamento da apelação n. 0308891-29.2017.8.24.0023, embora a Quarta Câmara de Direito Comercial do TJSC tenha decidido por aspectos formais ligados ao protesto, no relatório do acórdão percebe-se que a decisão de primeiro grau que deu origem ao recurso havia extinguido o processo de pedido de falência fundado no art. 94, inc. I da LRF sob o argumento de que não haviam sido esgotados os meios ordinários de cobrança.

${ }^{23}$ APELAÇÃO CÍVEL. FALÊNCIA. DESNECESSIDADE DE PROTESTO ESPECIAL. LEI N. 9.492/97. INEXISTENCIA DE MÁCULA NO PROTESTO DA NOTA PROMISSÓRIA. PRINCÍPIO DA PRESERVAÇÃO DAS ATIVIDADES EMPRESARIAIS. AUSÊNCIA DE COMPROVAÇÃO DA INSOLVÊNCIA DA DEVEDORA. NÍTIDA INTENÇÃO DE COBRANÇA FORÇADA DO DÉBITO. USO INADEQUADO DO PROCEDIMENTO FALIMENTAR. AÇÃO PRÓPRIA JÁ AJUIZADA PELA REQUERIDA. EXTINÇÃO MANTIDA. FUNDAMENTO DIVERSO. RECURSO CONHECIDO E DESPROVIDO. Vistos, relatados e discutidos estes autos de Apelação n. 0000854-49.2014.8.24.0037, da comarca de Joaçaba $2^{\text {a }}$ Vara Cível em que é Apelante Redfactor Factoring e Fomento Comercial S/A e Apelado Incoplastic 
No caso, a ação falimentar foi proposta por um credor com base no art. 94, inc. I da LRF, apresentando os títulos vencidos, cuja soma ultrapassava a 40 salários mínimos e os devidos instrumentos de protesto. $\mathrm{O}$ magistrado de $1^{\mathrm{o}}$ grau entendeu haver vício no protesto do título, por não ter sido observado o protesto especial, extinguindo o feito por falta de condição da ação. Referida decisão colegiada, no entanto, reconheceu ter sido observado pela parte autora o que determina da Súmula 361 do $\mathrm{STJ}^{24}$, declarando não haver mácula no protesto.

Entretanto, no corpo de seu voto, o relator passou a analisar o pedido não mais sob o viés da formalidade do protesto, mas a partir do princípio da preservação da empresa. ${ }^{25}$

O primeiro argumento apresentado no voto do relator da decisão é o de que "em que pese a inexistência de mácula no protesto da nota promissória, deve-se atentar que a decretação de falência de uma empresa só pode ser admitida em caráter excepcional, como ultima ratio", trazendo como fundamento citação doutrinária que apresenta as seguintes afirmações:

\begin{abstract}
A atividade empresarial afeta o mercado e a sociedade. O modo de produção econômica, no sistema capitalista, é determinante das demais instâncias sociais. Por isso, o interesse de agir nos processos regidos pela lei de falências e recuperação de empresas reside na necessidade de um provimento judiciário para deslindar não só a crise econômico-financeira de um empresário, mas toda espécie de relações daí decorrentes e suas repercussões sociais. A preservação da atividade negocial é o ponto mais delicado do regime jurídico de insolvência. Só deve ser liquidada a empresa inviável, ou seja, aquela que não comporta uma reorganização eficiente ou não justifica o desejável resgate" (Manual de direito comercial. 11ª Ed. São Paulo: Ed. Atlas. 2010, p. 576)
\end{abstract}

A partir destas premissas lançadas pelo próprio julgador, ele as subsume ao caso concreto com 2 afirmações: 1) "In casu, não foi devidamente comprovado pelo autor a situação de total insolvência da requerida que justifique o pedido de falência frente aos outros meios processuais previstos no ordenamento jurídico para satisfazer seu crédito, como, por exemplo, o processo de execução[...]"; 2)" Nesse contexto, é desarrazoado que um credor, munido de

\footnotetext{
- Indústria e Comércio de Plásticos e Papéis Ltda. A Terceira Câmara de Direito Comercial decidiu, por votação unânime, negar provimento ao recurso, em face da ausência de interesse de agir, conforme art. 267, VI, do CPC/73. Custas legais. Participaram do julgamento, realizado nesta data, o Exmo. Sr. Des. Tulio Pinheiro (Presidente), o Exmo. Sr. Des. Rodrigo Cunha e o Exmo. Sr. Des. Ronaldo Moritz Martins da Silva. Florianópolis, 17 de novembro de 2016. (Apelação n. 0000854-49.2014.8.24.0037, de Joaçaba Relator: Desembargador Rodrigo Cunha)

${ }^{24}$ Súmula 361, STJ: A notificação do protesto, para requerimento de falência da empresa devedora, exige a identificação da pessoa que a recebeu.

${ }^{25} \mathrm{Na}$ apelação o n. 0006490-84.2008.8.24.0011, de 13/10/2016, oriunda da Segunda Câmara de Direito Comercial do TJSC, identifica-se a mesma tendência. Neste caso, a questão da necessidade de protesto especial não foi superada, servindo como primeiro argumento para afastar a falência. No entanto, mesmo alegando esse vício, a Câmara ingressou na análise de mérito, para confirmar, pelos próprios fundamentos do magistrado de primeiro grau, uma "flexibilixação" da regra do art. 94, I da LRF em razão do princípio da preservação da empresa.
} 
título judicial que pode aparelhar uma execução individual, recorra ao pedido de falência do devedor (MC n. 011674/SP, rel. Ministro Ari Pargendler, DJ de 23/6/2006)". ${ }^{26}$

Em que pese a correção da premissa utilizada no acórdão acerca da excepcionalidade do instituo falimentar em face da possibilidade recuperatória, a subsunção ao caso concreto não atendeu aos próprios ensinamentos doutrinários apresentados como fundamento.

Primeiro, porque a citação doutrinária indicada não sugere a possibilidade de afastamento da regra do art. 94, inc. I da LRF, mas apenas alude genericamente à importância da atividade empresarial e os reflexos sociais da falência. Assim, não há uma subsunção lógica entre o argumento doutrinário e o alegado "desarrazoado" do pedido feito com base nas exigências legais.

Além disso, a primeira conclusão apresentada pelo relator de que é por conta do princípio da preservação da empresa que passa a ser obrigação do credor [sob pena de não ter interesse de agir] comprovar a situação de total insolvência da empresa devedora para justificar sua opção pelo procedimento falimentar, não se sustenta.

Conforme já referido, o próprio acórdão assente que todos os requisitos exigidos pela regra do artigo 94, inc. I da LRF foram atendidos, donde se extrai a possibilidade e utilidade do pedido de falência ${ }^{27}$, uma vez que, como apontado anteriormente, o instituto da falência possui fundamentos justificadores e de utilizadade próprios que não se confundem com os fundamentos e com a utilidade que se adviria de uma execução individual. Por conta disso, nossa legislação não obriga o credor a propor ação executiva, quando está diante dos requisitos que lhe permitem requerer a falência do devedor.

Ao remeter os credores que reúnem os requisitos legais suficientes para presumir a insolvência do devedor à execução individual, o acórdão esquece do princípio da par conditio creditorum como fundamento da execução coletiva falimentar e os obriga a se sujeitarem ao já apontado nefasto efeito que a falência pretende evitar [e que a justifica] que é a hipótese do prior in tempore, prior in iure, que beneficia apenas os credores com mais sorte no andamento de suas ações.

\footnotetext{
${ }^{26}$ Mesmos argumentos são utilizados no acórdão da apelação cível n. 0006490-84.2008.8.24.0011 da Segunda Câmara de Direto Comercial, na qual se afirma: “[...]Sob essa ótica, "o requerimento de decretação de falência só deve ocorrer quando o débito superar o limite mínimo de 40 salários mínimos e o credor tem certeza da insolvência do devedor, pois este não está em condições de efetuar o pagamento do crédito" (grifo nosso)

${ }^{27}$ Considera-se o interesse de agir a partir da perspectiva instrumental, como apontada por Humberto Theodoro Júnior, "O interesse que se reclama para a admissibilidade da ação não é o interesse substancial, ou primário, para cuja proteção se intenta a mesma ação. O interesse de agir, que é instrumental e secundário, surge da necessidade de obter através do processo a proteção ao interesse substancial."(LIEBMAN citado em THEODORO JÚNIOR, Humberto. Processo Cautelar. 16 ed.. São Paulo: Leud, 1995, p. 35)
} 
Além disso, exigir que o autor do pedido de falência comprove a situação de insolvência real para demonstrar seu interesse de agir é exigir-lhe o impossível e, portanto, é negar-lhe o exercício de seu direito de ação. É falaciosa a afirmação de que o autor deveria [ o que pressupõe que ele teria meios para isso] reunir documentos que apontassem que o passivo da devedora é maior que o seu ativo. No corpo do voto do relator, é citada decisão invocada como fundamento argumentativo na qual consta a seguinte afirmação "constituindo-se em conditio sine qua non a pedidos de tal natureza a existência de passivo excedente ao seu ativo, caracterizando a sua insolvência, afigura-se de todo carecedor de ação, por ausente o binômio necessidade/utilidade quem, sem comprovar tal requisito vem a pleiteá-la, por mero capricho ou vendeta, como sucedâneo de ação própria que lhe é disponibilizada pelo ordenamento jurídico vigente".(grifo nosso).

Ora, como esperam os magistrados que os credores tenham acesso à informação acerca de todo o passivo e de todo o ativo da empresa devedora?

Tal exigência, ademais, além de demonstração impossível, nega a adoção do sistema de presunção de insolvência pelo ordenamento falimentar brasileiro, invertendo o ônus da prova e subvertendo a ordem de atuação responsável distribuída pela lei entre credor e devedor diante de uma situação de insolvência: não é o credor que deve ir em busca de prova da situação econômica do devedor, mas sim o devedor, que tem o prazo de defesa para justificar a cessação do pagamento, apresentando seu pedido de recuperação judicial, se for o caso. ${ }^{28}$

Ressalte-se que o caput do artigo 94 da LRF estabelece que será decretada a falência do devedor que, sem relevante razão de direito, incorrer nas hipóteses elencadas em seus incisos, o que é complementado pelo já citado artigo 96 que estabelece que não será decretada a falência se, no prazo de defesa, o devedor apresentar uma relevante razão de direito para o não pagamento, ou apresentar pedido de recuperação.

Disso se extrai que a opção legislativa foi a de estabelecer a presunção de insolvência em favor do credor, concedendo ao devedor a possibilidade de elidir esta presunção na manifestão de defesa, o que fora subvertido pelo acórdão analisado, que sequer recebeu a inicial para permitir o exercício de defesa e a conseqüente apresentação de justificativa pela devedora.

\footnotetext{
${ }^{28}$ Nesse sentido, muitos estudos tem sido feitos acerca da responsabilidade das empresas pela demora em utilizar o pedido de recuperação judicial. Luisa Isabel Borgarello (2011, p. 153) destaca que "La prevención es un mecanismo vinculado a la alerta temprana y que por diferentes procedimientos intenta evitar que se desate la crisis insostenible que irremediablemente llevaría a la liquidación (...)Por eso ante la mera avizoración de la crisis, es fundamental el "timing problem" o sea cómo reacciona el deudor o los integrantes del órgano de administración societaria, cuando no del órgano de fiscalización, o los mismos socios de manera individual o a través del órgano de gobierno, tratando de evitar esos disvalores, incluso el efecto negativo de la desaparición de una empresa en el país."
} 
Aqui cumpre salientar outra contradição interna nos argumentos apontados no acórdão, pois a própria citação doutrinária utilizada como fundamento indica que somente a empresa viável deve ser preservada. No entanto, o acórdão invoca o princípio da preservação sem sequer citar a empresa e, portanto, sem confirmar faticamente o preenchimento do requisito de sua viabilidade econômica. Em outras palavras, os julgadores presumiram que a empresa devedora era viável ou presumiram que "toda e qualquer atividade empresaria é viável" e deve ser preservada, o que não se coaduna com o escopo do princípio da preservação da empresa.

Ainda, outro argumento invocado no acórdão sob exame, é o de que ao propor o pedido de falência, mesmo diante da apresentação dos requisitos legais, o credor não pode pretender apenas receber seu crédito. Nesse sentido, fez-se constar no corpo do acórdão:

\begin{abstract}
A ação de quebra não é substitutiva da ação de cobrança, impondo-se denegado o seu processamento quando a própria credora deixa entrever tê-la utilizado para haver o crédito que tem. Essa forma coercitiva de cobrança não é de ser admitida, ainda que detenha a credora título executivo protestado e tenha esgotado todos os meios suasórios para ver implementado seu crédito. (Ap. Cív. n. 00.023461-3, de Criciúma, rel. Des. Trindade dos Santos, DJ de 19.03.01). (Ap. Cív. n. 2000.012663-2, da Capital, Rel. Des. Cercato Padilha, DJ de 21.12.01 (TJSC, Apelação Cível n. 2008.023677-1, de São João Batista, rel. Des. Rodrigo Antônio, j. 26-8-2010)
\end{abstract}

O primeiro equivoco a ser apontado com relação a esse argumento é o de atribuição de caráter pejorativo ao interesse do credor impago pretender receber seu crédito por meio da execução coletiva. Conforme ressaltado no tópico 2 do presente estudo, o objetivo, tanto da falência quanto dos próprios modelos recuperatórios, é a realização de pagamento dos credores. O que os diferencia é a forma como ele será alcançado - mediante liquidação ou mediante recuperação - e que dependem do comportamento e das condições apresentadas pelo devedor e não do desejo idealizado e descontextualizado do aplicador da lei.

Conforme já exposto, a preocupação quanto à utilização desmedida dos pedidos de falência com base em obrigações de pequeno valor, como supedânio da ex ecução individual, foi levada em consideração pelo legislador e justificou a previsão do recrudecimento das exigências formais quanto ao valor e ao protesto dos títulos, não cabendo ao intérprete aumentar ainda mais essas exigências.

Importa, ainda, ressaltar que as decisões indicadas como precedentes, no sentido de aplicação do principio da preservação da empresa para afastar os pedidos de falência utilizados como mera ação de cobrança, referem-se a pedidos apresentados sob a égide do Dec.-Lei 7.661/45, quando inexistia valor mínimo como requisito formal para preseunção da 
insolvência. ${ }^{29}$ Assim, mostra-se equivocada a utilização dos precedentes invocados no acórdão da $3^{\text {a }}$ Câmara de Direito Comercial do TJSC, visto que não observam os mesmos pressupostos fáticos.

Desta forma, denota-se que, sob o manto do abstrato argumento de preocupação com a preservação da empresa, o acórdão analisado cria requisitos não exigidos pelo legislador para tal instituto, desconsidera o sistema de presunção de insolvência e os fundamentos axiológicos da falência e acaba por decidir contra-legem.

Ademais, restringido o acesso dos credores ao instituto que lhe é garantido por lei, o entendimento apresentdo no acórdão promove o desequilíbrio entre os dois principais interesses envolvidos numa situação de insolvência, forçando a balança para o lado dos devedores e relegando os credores à própria sorte com a execução individual. Ao provocar esse desequilíbrio interpretativo, retirando as possibilidades legais de ação dos credores, o aplicador da lei desconsidera os possíveis reflexos econômicos de uma legislação que só beneficia a empresa devedora, prejudicando, inclusive, a eficiência da legislação e da prórpia axiologia preservacionista.

Esquece, ainda, o julgador, que muitas vezes o credor também é uma empresa que merece proteção, pois vai sofrer as conseqüências nefastas pelo não recebimento de seu crédito, vai atrasar o pagamento de seus funcionários, de seus credores e de seus tributos, gerando o denominado "efeito cascata" da falta de pagamento.

Denota-se, portanto, que o princípio da preservação da empresa, aplicado de maneira generalizada e abstrata, não como fundamento axiológico, mas como objetivo tanto da falência, quanto da recuperação de empresas, se tornou uma porta demasiadamente sensível para a arbitrariedade judicial, de modo que a fundamentação das decisões que não fazem a subsunção adequada dos requistos legais de ambos os institutos à hipótese concreta merece ser revista.

Por fim, cumpre destacar, com as palavras de Robert Alexy (2008, pg. 105) que "uma regra não é superada pura e simplestmente quando se atribui no caso concreto, um peso maior ao princípio contrário ao princípio que sustenta a regra", de modo que a alegada interpretação sistemática que pretende "harmonizar o sistema" não pode significar afastar-se por completo dos fundamentos da norma interpretada. ${ }^{30}$

\footnotetext{
${ }^{29}$ O mesmo se identifica no acórdão n. 0006490-84.2008.8.24.0011 da Segunda Câmara de Direto Comercial, que utiliza diversas decisões que afastam o pedido de falência sob argumento de cobrança de valor insignificante por serem oriundos de pedidos ajuizados antes da existência de valor mínimo indicado pelo legislador.

${ }^{30}$ Sobre a diferença da força prima facie das regras e princípios, ver ALEXY, 2008, p. 104-106.
} 
A harmonização do sistema consursal se constroi, primordialmente, pelo respeito a todos os interesses concursais equilibrados pelo ordenamento jurídico, nos quais se inserem não só o principio da preservação da empresa e a proteção dos trabalhadores, mas também o direito dos credores e a tutela do crédito.

\section{Conclusão}

Foi com a instituição dos regimes recuperatórios e o recrudecimento das regras para instauração do pedido de falência que o legislador brasileiro trouxe para o seio da LRF o princípio da preservação da empresa, buscando compatibilizar o interesse público de manutenção da atividade economica com o interesse privado de recebimento do crédito pelos credores. Com esse espírito, o legislador de 2005 estabeleceu, no art. 94, inc. I da LRF, um mínimo para o montante das obrigações executáveis via liquidação falimentar, impedindo, assim, que pedidos de falência sejam formulados com base em obrigações de pequeno valor, exigíveis por outras vias processuais.

A limitação de algumas regras em prol da preservação da empresa pode se justificar, em alguns casos, dentro de um contexto em que a recuperação judicial já esteja instaurada, quando o devedor já tenha demonstrado o interesse e a viabilidade de utilização da via recuperatória. Entretanto, não de pode aplicar o ideário preservacionista de modo abstrato e generalizante.

Nesse sentido, buscou-se, com esse artigo, demonstrar o equívoco dos fundamentos das decisões que extinguem o processo de falência sem julgamento de mérito ab initio, pois atropelam o devido processo legal ao sequer oportunizar o controditório, agindo os próprios

julgadores como defensores, em abstrato, de toda e qualquer empresa. Tais decisões deixam de exigir da empresa devedora a atitude de justificar o não pagamento, oferecer medidas de pagamento ou pedir a recuperação judicial e passam a aceitar o argumento de que "mesmo devendo sem apresentar justificativa legal" a empresa, por ser fonte de riqueza, deve ser preservada pelo magistrado.

Ao aplicar o princípio da preservação da empresa como objetivo tanto da falência quanto da recuperação judicial, o julgador subverte os critéiros legais e as diferentes axiologias sob as quais de fundam cada um dos institutos, fechando os olhos para os reflexos econômicos do desequilibro do sistema concursal. 


\section{Referências bibliográficas}

ABRÃO, Carlos Henrique. Do procedimento para a decretação da falência. In: TOLEDO, Paulo F. C. Salles de; ABRÃO, Carlos Henrique (Coord.). Comentários à Lei de recuperação de empresas e falência. 6. ed. rev. atual. e ampl. São Paulo: Saraiva, 2016. p. 358 - 424.

ALEXY, Robert. Teoria dos Direitos Fundamentais. Tradução de Virgílio Afonso da Silva. São Paulo: Malheiros, 2008.

BARBOSA, Klênio, CARNEIRO, André, ELY, Regis A., RIBEIRO, Felipe Garcia. O impacto da nova lei de falências no mercado de crédito brasileiro. In: Economia Aplicada / Departamento de Economia, Faculdade de Economia, Administração e Contabilidade de Ribeirão Preto, Universidade de São Paulo - v.21, n. 3 - - Ribeirão Preto: FEA-RP, jul-set 2017. p. $469-501$.

BARREIRO, Marcelo Gustavo. Presupuestos y principios concursales: un intento de aproximación a la noción de “interés concursal”. Disponível em: https://www.institutoi beroamericanoderechoconcursal.org/images/doctrina/documentos/Presupuestos_Principios_C oncursales.pdf. Acesso em: 27 de abril de 2018.

BORGARELLO, Luisa Isabel. Prevención o liquidación. Estudios de Derecho Empresario -

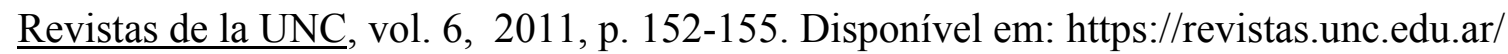
index.php/esdeem/article/view/13010. Acesso em: 27 de abril de 2018.

DASSO, Ariel G. La Supremacía del Derecho Concursal en situaciones de Insolvencia. In: Estudios de Derecho Empresario Escuela Comercialista de Córdoba y sus proyecciones, v. 10. Revista informática del instituto iberoamericano de derecho concursal número II año 2016, p. 199 - 208. Disponível em: https://www.institutoiberoamericanoderechoconcursal.org /images/revista_iidc/volumen_especial_IIDC.pdf. Acesso em: 03 de maio de 2018.

GRAU, Eros Roberto. A ordem econômica na Constituição de 1988. 14. ed.rev.atual. São Paulo: Malheiros, 2010. 
LONGONE, María Rosal. Consursalidad y Eficiencia Económica. In: . In: Cuarto Congresso iberoamericano de Derecho Concursal: crisis de la economía mundial y concursalidad. Uruguay: Fundación de Cultura Universitaria, 2008. p. 249-254.

MARTÍNEZ. Aurelio Gurrea. La escasa utilización de los procedimientos concursales: Causas, implicaciones y la necesidad de un cambio de paradigma en el estudio y el diseño del Derecho concursal en Iberoamérica. In: Estudios de Derecho Empresario Escuela Comercialista de Córdoba y sus proyecciones, v. 10. Revista informática del instituto iberoamericano de derecho concursal número II. año 2016, p. 49- 63. Disponível em: https://www.institutoiberoamericanoderechoconcursal.org/images/revista_iidc/volumen_espe cial_IIDC.pdf. Acesso em: 03 de maio de 2018.

$\underline{\text { La incomprensible preferencia del convenio a la liquidación como solución del }}$ concurso. Disponível em: https://hayderecho.com/2017/06/12/la-incomprensible-preferenciadel-convenio-a-la-liquidacion-como-solucion-del-concurso/. Acesso em: 02 de maio de 2018.

NEGRÃO, Ricardo. Curso de direito comercial e de empresa:recuperação de empresas, falência e procedimentos concursais administrativos. vol. 3. 11 $1^{\mathrm{a}}$ ed. São Paulo: Saraiva, 2016.

RAMME, Adriana Santos. Recuperação Judicial \& Dívidas Tributárias: a preservação da empresa como fundamento constitucional de ajuda fiscal. Curitiba: Juruá, 2013.

RASPALL, Miguel A. El proceso de homologacion o confirmacion: participación, solicitación y voto de acreedores y demás requisitos para aprobación judicial de un plan de reorganización (consensual y no consensual); los derechos y la participación de acreedores en el proceso de saneamiento de una empresa bajo los distintos regímenes concursales existentes. Estudios de Derecho Empresario.Volumen Especial 10. Revista informática del instituto iberoamericano de derecho concursal número II. Año 2016. p. 85 - 100. Disponível em : https://www.institutoiberoamericanoderechoconcursal.org/images/revista_iidc/volumen_espe cial_IIDC.pdf Acesso em: 03 de maio de 2018.

RICHARD, Efrain Hugo. Perspectiva del derecho de la insolvência. Córdoba: Academia Nacional de Derecho y Ciências Sociales de Córdoba, 2010. 
THEODORO JÚNIOR, Humberto. Processo Cautelar. 16 ed. São Paulo: Leud, 1995.

TOMAZETTE, Marlon. Curso de direito empresarial: Teoria geral e direito societário, v. 3 8. ed. rev. e atual. São Paulo: Atlas, 2017.

TRUFFAT, E. Daniel. El carácter imprescindible de la concursalidad frente al fenômeno de la insolvência. In: Cuarto congresso iberoamericano de derecho concursal: crisis de la economía mundial y concursalidad. Uruguay: Fundación de Cultura Universitaria, 2008. p. 289-294.

ZABALETA DÍAZ, Marta. El principio de conservación de la empresa en la ley concursal. Navarra: Thomson Civitas, 2006. 


\section{ANÁLISE ECONÔMICA DO DIREITO E SUA APLICAÇÃO NO BRASIL: UM ESTUDO A PARTIR DO PARADIGMA DO ESTADO DEMOCRÁTICO DE DIREITO NA CONSTITUIÇÃO DA REPÚBLICA FEDERATIVA DO BRASIL DE 1988}

Leonardo José Peixoto Leal

Universidade Federal do Ceará e Universidade de Fortaleza - UNIFOR Valter Moura do Carmo Universidade Federal de Santa Catarina e Universidade de Marília - UNIMAR

\section{Resumo}

Este estudo tem como objetivo analisar o instituto da Análise Econômica do Direito - AED e sua aplicação no Brasil a partir de 1988. Trata-se de pesquisa bibliográfica e documental, cujo tema tem relevância. Conclui-se que a disseminação da AED no Brasil tem ocorrido de forma mais contundente em campos específicos, como o direito antitruste, e que o uso desse instrumental pode ser de grande utilidade. Contudo, não se podem olvidar os aspectos Constitucionais e legais vigentes, de modo a compatibilizar a visão econômica e jurídica e sociais presentes na Constituição e decorrentes do paradigma do Estado Democrático de Direito.

Palavras-chave: Análise Econômica do Direito, Paradigma, Estado Democrático, Ordem Econômica.

\footnotetext{
Abstract/Resumen/Résumé

This study aims to analyze the Institute of Law\&Economics and its application in Brazil since 1988. It is a bibliographical and documentary research, whose theme has relevance. It is concluded that the dissemination of AED in Brazil has occurred more forcefully in specific fields, such as antitrust law, and that the use of such instruments can be very useful. However, we can not forget the current Constitutional and legal aspects, in order to reconcile the economic and legal and social vision present in the Constitution and stemming from the paradigm of the Democratic State of Law.
} 
Keywords/Palabras-claves/Mots-clés: Law\&Economics, Paradigm Democratic, State, Economic Order.

\section{Introdução}

Este artigo objetiva investigar a viabilidade do uso e aplicação da chamada Análise Econômica do Direito - AED no Brasil, a partir dos contornos estabelecidos na Constituição da República Federativa do Brasil de 1988 - CRFB/88, sob a perspectiva da compreensão dos conceitos de empresa e de mercado hoje presentes na seara do direito e da economia. O objetivo é identificar a viabilidade da aplicação conjunta dessas estruturas jurídicas e suas eventuais desconformidades, destacando-se, ainda, os ramos do direito em que esse instrumental se revela mais comumente referido e utilizado.

A análise econômica do direito surge nos Estados Unidos e se solidifica a partir da década de 60 tendo, ao longo dos anos, se espalhado por diversos países e gerado, inclusive, variadas formas de entendimento e aplicação desta corrente de pensamento que, em suma, defende a união das ciências jurídica e econômica com influências recíprocas nas metodologias de análise e aplicação.

No Brasil, a AED ganha maior expressão a partir da década de 90, passando a se tornar assunto recorrente nas universidades e em escritos de Direito e de Ciências Econômicas. De forma mais espaçada começa, também, a ser discutida em órgãos administrativos e tribunais em análises de casos onde a relação entre direito e economia se revela mais próxima.

Surge, a partir de então, a necessidade de se compreender a AED e identificar a presença ou não de sua compatibilidade com a Ordem Jurídica Constitucional vigente no Brasil. A Ordem Econômica na Constituição de 1988 se coaduna à existência do paradigma do chamado "Estado Democrático de Direito", através do qual se admite que a sociedade estabeleça democraticamente, pela via direta ou por intermédio de representantes eleitos, quais são os preceitos e direitos sociais que devem ser respeitados e resguardados tanto na Constituição como nas normas infraconstitucionais, conferindo, assim, maior legitimidade aos direitos sociais que limitam a livre atuação dos agentes de mercado.

Neste estudo, aborda-se inicialmente a análise econômica do direito pelas principais escolas de aplicação; em seguida, analisa-se a evolução da relação entre Estado e Economia no modelo capitalista; após, trata-se da Ordem Econômica na Constituição de 1988; por fim, investiga-se a relação entre esses mecanismos e a viabilidade do uso da AED. 
Trata-se de temática atual estreitamente ligada aos interesses sociais em voga, correspondendo a assunto cuja discussão e análise é necessária para que se possa garantir um ambiente concorrencial e a existência de empresas e mercados eficientes e úteis à sociedade.

\section{Análise Econômica do Direito}

A Análise Econômica do Direito é a disciplina que se propõe a estudar o Direito pelo prisma da ciência econômica, pugnando pela aplicação dos princípios econômicos dentro das instituições jurídicas. Como afirma Ivo Teixeira Gico Júnior (2010, p. 18), “a AED é a utilização da abordagem econômica para tentar compreender o direito no mundo e o mundo no direito". A ideia de visão baseada em AED é, basicamente, a união das ciências jurídica e econômica, aplicando conceitos econômicos no direito, como racionalidade dos agentes, bem como a busca da eficiência econômica, na aplicação do direito e não do critério subjetivo de justiça.

Elisabeth Farina (2005, p. XIII) lembra a importância e a adequação da análise conjunta dos dois ramos, sobretudo em áreas jurídicas específicas como o Direito Antitruste, ramo em que a relação entre direito e economia se apresenta como mais evidente. $\mathrm{O}$ uso da AED não elimina tradição e metodologia da ciência jurídica construída no Brasil, podendo ser utilizada como mais um prisma, uma possibilidade de caminho, não se revelando caminho único e detentor de soluções de todas as questões jurídicas não esclarecidas, mesmo que o campo do direito tenha direta interface com a economia como são os casos da defesa do consumidor e da defesa da concorrência,

O apego excessivo à ideia do eficientivismo acarreta uma desconexão com primados fundamentais do direito, como as noções de equidade e justiça normalmente ignoradas pela lógica da eficiência econômica. Os economistas Paulo Krugman e Robin Wells citados por Fabiano Del Masso (2007, p. 160), exemplificam situação em que um estado ditatorial conta com soberano que controla tudo, guardando para si todos os recursos produzidos pela economia e concedendo aos demais somente o mínimo de que necessitam para viver ${ }^{1}$, e destacam que o modelo resulta em economia plenamente eficiente, conforme os critérios ${ }^{2}$ propostos para aferição desse elemento. Embora a situação possa ser eficiente, é claramente injusta ${ }^{3}$.

\footnotetext{
${ }^{1}$ É perceptível a nítida inspiração no Socialismo implementado em alguns países ao longo da história para exemplificação.

${ }^{2}$ São muitos os critérios que definem a presença ou não de eficiência em uma situação. O presente artigo se ocupará de alguns deles.

${ }^{3}$ Há que se registrar que também profundos e eivados de divergência são os debates sobre o conceito de Justiça. Michael Sandel (2014, p. 28-29) afirma que são três as correntes principais na definição de um conceito de justiça. A primeira parte da noção da maximização do bem-estar social, muito próximo à lógica welfarista apresentada no
} 
Há críticas a esse pensamento, principalmente em países de tradição jurídica romanogermânica, como é o caso do Brasil, argumentando-se essencialmente diferenças metodológicas entre economia e direito, principalmente o fato de o Direito pautar-se sempre pelo critério de justiça (relação com o direito natural) enquanto a economia busca a eficiência (que muitas vezes pode gerar situações consideradas moralmente injustas); bem como alegando-se que a visão econômica é demasiadamente simplista para a complexa realidade das relações sociais tuteladas pelo Direito.

Em resposta a críticos, Rachel Sztajn (2005, p. 82) destaca que esta busca conferir maior eficiência às normas jurídicas, o que não corresponde, necessariamente, a movimento novo, já que desde o Direito Romano os pretores já estariam preocupados com uma eficiência na distribuição de justiça e respeito às normas sociais. Colocar-se contra essa interseção seria elemento que contraria a própria racionalidade.

Não se trata, contudo, de posicionamento contrário ao diálogo entre direito e economia, de fato, impossível de ser afastado. Critica-se o apego demasiado aos aspectos econômicos, em detrimento dos jurídicos, supervalorizando a economia e desvalorizando a ordem jurídica vigente, seus preceitos, elementos científicos, princípios, normas e regras.

Tomando como exemplo a Europa, José Maria Arruda de Andrade (2014) afirma que em tempo recente, a defesa da concorrência, no continente, sofreu um fenômeno que nomina de "economização", ao qual se atribui a expressão more economic aproach, ou seja, a necessidade de incrementarem-se mais elementos econômicos nesse ramo do direito em específico. Entretanto, critica justamente o apego excessivo a postulados econômicos, sugerindo que a economia contribuíra muito para o direito, sobretudo para o direito concorrencial, estando na hora de se promover, para além da AED, a “Análise JurídicoEconômica" da análise econômica do direito, ou seja, proceder ao processo inverso e de complementaridade, da mesma forma que a economia como ciência é útil ao direito concorrencial, o direito enquanto ciência deve ser útil à economia.

Ronald Coase (1990, p. 27-28) adverte que o critério de eficiência econômica é benéfico à sociedade, já que visa a bem-estar social. Ou seja, a política econômica visa estimular comportamentos de indivíduos que promovam melhores resultados para o sistema econômico como um todo.

tópico anterior; a segunda atrela justiça à noção de liberdade com forte influência da doutrina liberal; e a terceira via é a das teorias que visualizam a justiça como decorrência de virtudes e de uma vida boa, satisfatória. A complexidade do conceito de justiça é ampla e escapa dos limites proposto por esta tese, razão pela qual não será enfrentada por este estudo. 
$\mathrm{Na}$ visão de eficiência proposta por Coase, há forte preocupação com os custos envolvidos nas interações de mercado. Desenvolve-se o teorema de Coase, pelo qual a redução dos custos de transação serve de tônica à aferição de eficiência econômica, sobre isso são as palavras de KRAUSE (2006, p.38).

No modelo capitalista, a economia faz parte das relações sociais desde atos mais simples e comezinhos. A todo instante, as pessoas tomam decisões sobre o que comer, o que vestir, deslocamento, onde trabalhar, por quanto desempenhar o trabalho, o que comprar, e tudo isso é economia, alertam Joseph Stiglitz e Carl Walsh (2003, p. 23):

Todos pensam na economia pelo menos parte do tempo. Pensamos em dinheiro (queremos ter mais) ou em trabalho (desejamos ter menos). Mas os economistas têm um modo particular de abordar as questões econômicas, e um dos propósitos deste curso é apresentar essa forma de pensar. Este capítulo começa com um modelo básico da economia. A isto se seguirá um exame mais detalhado de como as unidades básicas do sistema econômico - pessoas, empresas e governo - fazem escolhas em situações em que se defrontam com escassez. Escolhas envolvem trade-offs - gastar dinheiro na compra de um item significa que sobra menos para gastar com outras coisas. Entender como os economistas estudam esses trade-offs e como analisam as decisões de pessoas, empresas e governos é fundamental para aprender a pensar como um economista.

Como já visto, os trade-offs são fruto da escassez do sistema de produção humano. Os recursos postos na sociedade são escassos, invariavelmente, e, por isso mesmo, não satisfazem a todos indistintamente. Ivo Gico Júnior (2010) afirma que caso os recursos não fossem escassos, não existiram conflitos, nem necessidade do Direito. Evidente que a escassez, maior ou menor, depende do objeto e de qual o local da interação/troca.

A fixação de preços leva em consideração justamente os aspectos de escassez e de interesse, daí por que a necessidade de liberdade no estabelecimento, como aponta Martin Krause $^{4}$ (2006, p. 18), caracterizando-se o sistema de preços como um poderoso e engenhoso sistema de trocas de informações e de estratégia de comportamento tanto de consumidores, como de empresas e trabalhadores.

Se se dizem desejos humanos infindáveis, o mesmo não se faz com os recursos para satisfazê-los. Exatamente por isso é que os homens, a todo o momento, realizam escolhas,

\footnotetext{
${ }^{4}$ Los precios son los medios informativos por los cuales los consumidores transmiten sus apetencias y llaman la atención sobre lo que es conveniente producir. Por supuesto que no son indicadores perfectos, por algo las empresas dedican cuantiosos recursos y esfuerzos para obtener información adicional sobre las preferencias de los consumidores, y lo hacen por medio de estudios de mercado, por el análisis de su comportamiento e, incluso, hasta analizando la basura para determinar lo que efectivamente se consume.
} 
buscando sempre satisfazer desejos pessoais. A melhor alocação de recursos escassos, atendendo à maior quantidade possível de pessoas, encara-se com medida de eficientismo econômico.

Entre os critérios de fixação de lógica eficientista, esta tese se ocupa de dois: Pareto eficiente e aferição segundo a lógica nominada Kaldor-Hicks. Em seguida tem-se a Teoria dos Jogos como método de avaliação da interação em ambientes de mercado visando ao alcance de eficientismo. Por fim, a abordagem de três escolas de pensamento, voltadas especificamente para relação entre direito e economia.

A eficiência em Pareto dá-se sempre que a situação beneficia alguém sem prejuízo a outro indivíduo, ou seja, caso o benefício de um ocasione prejuízo a outrem, a situação não é eficiente. Já no critério Kardor-Hicks, a situação é eficiente sempre que o valor da riqueza do ganho ou benefício for superior à perda ou ao prejuízo experimentado por outro indivíduo. (PINHEIRO; SADDI, 2006, p.120-121).

O ótimo de Pareto tem influência ética, com carga moral, no sentido de buscar a solução eficiente em relação ao bem-estar coletivo. O critério Karldor-Hicks baseia-se em fatores econômicos, leva em consideração a quantidade de riqueza e bem-estar gerado na relação, de acordo com os critérios de análise econômica do direito, inerentes à política antitruste. Diante dos elementos de Pareto, o mesmo autor (2006, p. 23) destaca que a concretude dos postulados, no mundo real, se revela absolutamente inviável.

A evolução do estudo, no Brasil, dá origem a dimensões epistemológicas conhecidas da AED: dimensão positiva e dimensão normativa. Bruno Salama (2008, p. 4) distingue a dimensão positiva da dimensão normativa claramente, afirmando que a primeira se ocupa das repercussões do Direito no mundo dos fatos, ou seja, as consequências práticas derivadas das prescrições jurídicas; já a segunda estuda os meios de comunicação entre as noções de justiça, eficiência econômica, maximização de riqueza e maximização de bem-estar.

Enquanto a dimensão positiva se preocupa com a investigação de acontecimentos no mundo dos fatos, a dimensão normativa se preocupa com o mundo dos valores. Naquela se pode investigar pelo método científico, por isso, passível de erro e falsificação ${ }^{5}$; nesta, não é

\footnotetext{
5 A epistemologia, segundo Karl Popper (1993), necessita de várias experiências até a comprovação da teoria. Houve a virada do pensamento epistemológico ao se entender que o cientista deve primeiro criar a ideia e depois analisar e começar a fazer experimentos, a teoria deve ser feita antes e testada pelo experimento podendo ser comprovada ou não.

Gaston Bachelard (1971, p. 23-26) demonstra que o conhecimento científico rompe necessariamente com o conhecimento vulgar, diante de que, há sempre obrigatoriedade de comprovação do conhecimento científico. Assim, o conhecimento científico é fruto não de dados fornecidos pela realidade, mas de experimentos realizados pelo sujeito.
} 
científico o modelo, por isso impossível de investigação pelo método empírico. (GICO JUNIOR, 2010, p. 19)

Adotar uma ou outra dimensão da AED, entretanto, não importa esquecer totalmente a outra. Em resumo, dimensão positiva explica os fatos, é eminentemente descritiva e explicativa. A normativa, por outro lado, apresenta a opção mais eficiente a ser adotada, em determinado caso, sempre partindo de paradigma normativo.

\section{Escolas de Aplicação da AED}

O estudo da AED pode ser feito pelas chamadas "escolas" dessa vertente de pensamento que ora correspondem a locais em que tal corrente ganha força e passa a ser objeto de estudo e análise, ora a características específicas do modo de promover a análise de interação entre direito e economia. A seguir, apresentam-se algumas dessas escolas.

\subsection{Escola de Chicago}

A escola de Chicago é a precursora da Análise Econômica do Direito, que inicialmente aplica conceitos econômicos, principalmente da economia Neoclássica e da microeconomia, às instituições jurídicas em busca de solução dos problemas sociais, desenvolvendo, em sequência, os próprios postulados econômicos.

Suas preocupações iniciais voltam-se para questões eminentemente econômicas, direito concorrencial e tributário. Somente por volta de 1960, é que a Análise Econômica do Direito se encara como método aplicável a todos os ramos jurídicos.

Richard Posner, considerado um dos principais autores da Análise Econômica do Direito, pertence à escola de Chicago. Por várias vezes afirmou que o verdadeiro conceito ético do Direito é a busca da maximização de riqueza. Era esse o seu conceito de eficiência. Em face de críticas, Posner modifica seu pensamento, considerando não só a maximização de riqueza (eficiência) como o objetivo a ser buscado pelo Direito ${ }^{6}$, relativizando, assim, a rigidez da

\footnotetext{
${ }^{6}$ Posner passou boa parte da década de 1980 defendendo-se de seus críticos - juristas, filósofos e economistas. Em 1985, quatro anos após sua nomeação pelo presidente Ronald Reagan para o cargo de juiz do Sétimo Circuito, publicou um artigo denominado Wealth Maximization Revisited ("Maximização da Riqueza Revisitada"). Nessa obra, Posner iniciou seu processo de reconsideração da sua posição. Em um primeiro momento, a "reconsideração" de Posner foi bastante modesta. Ao final, seu argumento reforçava sua convicção de que a maximização da riqueza seria no mínimo tão protetiva dos direitos e liberdades individuais quanto os demais critérios defendidos pela tradição liberal. A maximização da riqueza estaria, então, firmemente assentada na filosofia liberal ocidental nomeadamente (e claro, seletivamente) em Locke, Kant, Jefferson e acima de tudo em Hobbes. [...] Em 1990, Posner jogou a toalha. Naquele ano, com a publicação de "Problemas de Filosofia do Direito", Posner definitivamente abandonou a defesa da maximização de riqueza como fundação ética do direto. A teoria da maximização da riqueza, escreveu Posner, "tem sido extremamente polêmica por sua própria natureza. Em sua maior parte, os que contribuem para o debate sobre ela concluem que se trata de uma teoria insatisfatória, e ainda
} 
teoria. Continuara, porém, acreditando que este deveria ser o norte a ser buscado pelos operadores do Direito (eficiência). Por fim, Posner modifica o pensamento de forma radical, compreendendo que a maximização da riqueza não é preponderante, mas apenas elemento a ser aliado ao conjunto de valores para cada caso. Talvez a condição de magistrado tenha contribuído, na prática jurídica, para a mudança de entendimento. (SALAMA, 2012)

Daniel Goldberg (2006) destaca que a visão da escola de Chicago se baseia na compreensão de que a preocupação geral do direito antitruste é a promoção de eficiência econômica, deixando-se de lado elementos de política pública estatal, servindo assim como berço da regra de razão e modelos adotados pela autoridade antitruste para verificação de condutas e atos de concentração.

A década de 80 é marco da escola de Chicago em perspectiva mundial de defesa da concorrência e, no caso do Brasil, pouco mais tarde, a partir da década de 90. (GOLDBERG, 2006).

Não obstante críticas à escola de Chicago, por exemplo, adoção de eficiência como parâmetro ético do Direito, nota-se a importância do seu pensamento para a AED e para própria defesa da concorrência, primeira escola de pensamento a levantar o debate acadêmico acerca dos efeitos econômicos das normas e instituições jurídicas, uma das escolas mais influentes no mundo, com vários adeptos no Brasil.

\subsection{Escola Austríaca}

Diferentemente da escola de Chicago, a Austríaca não vê na eficiência o fim máximo do Direito. Para os austríacos, o Direito não serve para moldar a sociedade, mas sim para garantir direitos individuais de agentes. O objetivo do Direito é a maximização de liberdades individuais, que só encontram limites na invasão de esferas de liberdade de pessoas.

Em teóricos e autores seguidores da teoria, há forte valorização de compreensão da natureza humana como elemento diretor de interações entre os indivíduos. Sobre a natureza humana na escola austríaca traz-se o pensamento de Dina Kallay (2004, p. 39), segundo o qual a escola austríaca diferencia-se da economia neoclássica por conta de sua natureza sociológica descritiva.

que muitas dessas críticas possam ser respondidas, algumas não são passíveis de resposta”. E, deste modo, Posner reviu sua posição, desta feita de maneira radical. (SALAMA, 2012). 
A autora segue enfatizando que Fridrich Hayek demonstra claramente a perspectiva austríaca ao afirmar que o foco da economia deve ser o de buscar a obtenção do melhor uso dos recursos disponíveis e não a projeção de situações ideais ou possíveis, mas inexistentes no plano fático, como adoção de modelos ou divagações. A economia deve ser pragmática, e esse viés é o que se revela mais útil ao direito e às normas. (KALLAY, 2004)

O pensamento se coloca como posição contrária ao intervencionismo. Enquanto a escola de Chicago defende que as autoridades antitruste intervenham para garantir o alcance da eficiência econômica, a austríaca defende o fim do direito antitruste e, em verdade, a máxima redução da ingerência estatal no campo econômico, pois, pelos postulados da linha de pensamento, somente a liberdade efetiva garante a existência de ambiente competitivo e eficiente do ponto de vista econômico.

\subsection{Pós-Chicago}

Diante das críticas, a escola de Chicago surge como nome de Pós-Chicago, movimento de autores que não necessariamente se filiando a outra escola da AED em específico, como a escola austríaca, se contrapõem às definições e pressupostos chicaguistas. Daniel Crane (2009, p. 1923) aponta que a escola de Chicago é recorrentemente acusada de muito teórica e pouco prática, eivada de elementos simplificadores e desconectada de possíveis efeitos reais.

\footnotetext{
Além da sugestão de que Chicago representa uma força de ataque direito em vez de um pensamento econômico sólido, as principais críticas vindas de Chicago é de que ela seria muito teórica, simples, especulativa e sem energia. Com isso, Kauper se queixa da "disparidade entre o modelo de Chicago e os fatos prováveis" e sugere que Kodak envolve um caso de "fatos prováveis" que superam a especulação em Chicago (p 47). Fox argumenta que Chicago especulou que o preço predatório poderia acontecer raramente, se alguma vez, enquanto que "a bolsa de estudos estabelece, pelo contrário, que a predação seletiva do preço é um fenômeno recorrente" (p. 82). Calkins argumenta que "há muita especulação sobre os efeitos do comércio exclusivo, mas não há pesquisa empírica suficiente" (p. 167) (Traduziu-se ${ }^{7}$ )
}

\footnotetext{
${ }^{7}$ Beyond the suggestion that Chicago represents a right-wing power grab rather than sound economic thinking, the major criticism emerging from How Chicago is that Chicago is too theoretical, simple, speculative,and unempirical. Thus, Kauper complains of the "disparity between Chicago's model and provable facts" and suggests that Kodak involves a case of "provable facts" trumping Chicagoan speculation ( $p 47)$. Fox argues that Chicago speculated that predatory pricing could happen rarely, if ever, whereas "[s]cholarship establishes, to the contrary, that selective price predation is a recurring phenomenon" ( $\mathrm{p}$ 82). Calkins argues that" $[\mathrm{t}] \mathrm{h}$ )re is a lot of speculating about the effects of exclusive dealing but not nearly enough empirical research" (p 167).
} 
Daniel Goldberg (2006, p. 91) cita o discurso de Jonathan Baker, em 1980, em que o economista sustenta que a simplificação das ideias de Chicago pode findar por estabelecer leniência no campo concorrencial prejudicial à efetividade competitiva e à própria lógica de eficiência alocativa.

Não bastando isso, insta lembrar que os agentes econômicos agem dotados de racionalidade e possuem comumente rápida capacidade de atuação, não sendo absurdo supor que, uma vez constatado o desapego da autoridade antitruste, na análise de determinados elementos com base em postulados econômicos, estimula esses mesmos agentes a se utilizarem de recurso para, impunemente, cometer ilícitos que os favoreçam e não despertem intervenção estatal.

Hebert Hovenkamp (2005, p. 03) destaca que a escola de Chicago contribuiu negativamente para formação de autoridade antitruste muito confiante no mercado e na capacidade de adaptação pró-competitiva em casos de alterações, o que talvez justifique, sobre sua influência no Brasil, o elevado número de atos de concentração prontamente aprovados pelo $\mathrm{CADE}^{8}$, medidas restritivas de pouca ou nenhuma efetividade prática e a baixa preocupação com o controle de condutas. Para o autor, contudo, o movimento Pós-Chicago tem se mostrado menos condescendente com concorrentes e mais preocupado com os resultados finais e proteção dos consumidores.

Daniel Crane (2009) afirma a existência do movimento que nomina de "Neo-Chicago" que busca promover equilíbrio entre as visões chicaguistas e pós-chicaguistas. É certo, contudo, que o modo de visão tanto da relação do direito com a economia, como mais especificamente, do direito antitruste e da economia, tem sido objeto de transformação não só nos Estados Unidos, mas em todos os países. Parece tendência a busca pelo modelo equilibrado entre os aspectos jurídico e econômico.

Desse modo, o ramo em que a relação entre direito e economia é mais evidente é o do direito antitruste. Os impactos econômicos ocorrem por via reflexa da aplicação e fixação de normas em outros ramos do direito, na defesa da concorrência a economia é o seu próprio objeto de análise. Necessário que o legislador, intérprete e aplicador da norma estejam sempre conscientes dos impactos econômicos da ação/decisão, e ferramentas como a AED e a Teoria dos Jogos são úteis para otimização do processo.

\footnotetext{
${ }^{8}$ Apenas no ano de 2016, dos 147 casos de Atos de Concentração julgados pelo CADE, 140 foram aprovados sem qualquer restrição. (Fonte: www.cade.gov.br)
} 


\section{Paradigma do Estado Democrático de Direito - Intervencionismo x Liberalismo}

Neste tópico, faz-se um resgate sucinto da evolução do pensamento econômico baseado essencialmente nos autores: Nali Jesus de Sousa (2009), José Luis de Magalhães (2000), Norberto Bobbio (2007), André Luiz Santa Cruz Ramos (2015), Paulo Bonavides (2007; 2013) e Eros Grau (2004). Importante destacar que a tese não propõe levantamento histórico devidamente delimitado e detalhado dos elementos a serem apontados, mas tão somente contextualização inicial com limitações e sem compromisso de aprofundamento fático dos elementos narrados. Trata-se de apanhado do que se tem como consensual nos históricos realizados, feito, importante registrar, com saltos temporais de significativa elasticidade, vez que o resgate histórico e preciso não faz parte do objeto da pesquisa buscando-se, a princípio, a compreensão do atual momento vivido.

Nas tribos primitivas, as relações econômicas, na maioria, se limitavam à busca pela sobrevivência, com a prática de escambos de bens e excedentes sendo quaisquer divergências resolvidas pelos líderes tribais ou através da autotutela. Já na filosofia Grega, o ambiente econômico perde espaço, na medida em que se defendia o pensamento de que a atividade da economia era algo de menor importância ${ }^{9}$, matéria da qual os intelectuais e cultos cidadãos não deveriam se ocupar (SOUSA, 2009, p. 2-3).

A formação dos feudos contribui para economias estáticas e focadas na produção e exploração da atividade econômica local. A divisão de classes entre nobreza e plebeus acarreta abismais desigualdades sociais e fortalece o sistema de exploração quase escravagista da população em prol da satisfação da realeza que se consolida pelos privilégios de nascimento e uso da força. Os Estados nasceram de feudos e os senhores feudais se converteram reis ${ }^{10}$.

Com o desenvolvimento do Mercantilismo, após o declínio da conjuntura territorial do feudalismo, a economia volta a ganhar grande importância do ponto de vista teórico, havendo, no período, a adoção de postura eminentemente liberal. Nessa perspectiva, os primeiros movimentos constitucionalistas do ocidente ${ }^{11}$ foram marcados pelo chamado paradigma do Estado Liberal, caracterizado pela garantia de liberdades individuais, separação dos poderes na estrutura do Estado (Executivo; Legislativo; Judiciário), império da Lei e uma postura econômica não intervencionista.

\footnotetext{
${ }^{9}$ A depeito disso, como se verá no capítulo 4, remonta à Grécia um dos primeiros registros de intervenção estatal para garantia da existência de um ambiente concorrencial.

${ }^{10} \mathrm{O}$ surgimento das Monarquias variará na evolução da Europa e muitos decorrerão da junção de vários feudos. Há longa fase de transição ainda em que a divisão do Estado-Nação em feudos é mantida.

${ }^{11}$ Movimentos que se iniciaram coma Magna Carta de 1.215 na Inglaterra e se disseminou ao longo dos séculos.
} 
A realidade eclodiu num liberalismo exacerbado, de nítida ruptura com o absolutismo e domínio absoluto da monarquia, destacando-se a necessidade de garantia de iguais oportunidades a todos, independentemente de privilégios de nascimento, havendo essa perspectiva praticamente reinado entre os séculos XVII e XVIII. Nesse sentido, afirma Norberto Bobbio (2007, p. 429-430):

Foi exatamente no momento culminante de forma de organização do poder, no âmbito do estado absoluto, que se operacionalizou a colocação em crise da legitimação exclusiva do príncipe à titularidade do próprio poder através da tentativa de requalificação política das posições privadas que no período intercalar se vinham mais ou menos conscientemente organizado a nível social. [...] A passagem da esfera da legitimidade para esfera da legalidade assinalou, dessa forma, uma fase ulterior do estado moderno, o estado de direito fundado sobre a liberdade política (não apenas privada) e sobre a igualdade de participação (não apenas pré-estatal) dos cidadãos (não mais súditos) frente ao poder, mas gerenciados pela burguesia como classes dominantes, com os instrumentos científicos fornecidos pelo direito e pela economia na idade triunfal da Revolução Industrial.

Na perspectiva liberal, destaca Manoel Gonçalves Ferreira Filho (1990, p. 3) que a "primeira geração de constituições" não cuidou de tratar, em seus textos, da intervenção do Estado no domínio econômico. Em verdade, as cartas constitucionais são marcadas pelo ideário liberal do laisssez faire, ou seja, da não intervenção estatal, razão pela qual a previsão dessa natureza no âmbito constitucional diz-se desnecessária, havendo confiança na tese de Adam Smith, da "mão invisível do mercado".

Entretanto, a realidade se mostra diversa do esperado. A tão sonhada igualdade não se concretiza no sistema capitalista, como destaca José Luis de Magalhães (2000, p. 44):

\footnotetext{
Esse individualismo dos séculos XVII e XVIII corporificado no Estado Liberal e a atitude de omissão do Estado diante dos problemas sociais e econômicos conduziu os homens a um capitalismo desumano e escravizador. O século XIX conheceu desajustamentos e misérias sociais que a Revolução Industrial agravou e que o Liberalismo deixou alastrar em proporções crescentes e incontroláveis.
}

Nesse contexto, importa lembrar que o ser humano, quase que de forma instintiva, sempre busca a satisfação das necessidades. Dessa forma, não há necessidade de Lei determinando a abertura de empresas, ou a atuação do setor privado nos campos $\mathrm{X}$ ou $\mathrm{Y}$ porque o processo ocorrerá naturalmente. Em verdade, tradicionalmente, o Direito tem condição de 
coibir, proibir ou limitar o exercício de qualquer atividade econômica, razão pela qual se nutre pela figura estatal natural antipatia dos empresários e até mesmo de economistas ${ }^{12}$.

É reconhecida, todavia, a necessidade de o Estado atuar na condição de regulador, vez que a liberdade absoluta pode acarretar, como já o fez em diversos momentos históricos, graves problemas e crises. Aliado aos aspectos acima apontados, Paulo Bonavides (2007, p. 139) enfatiza o contexto que estabeleceu a crise do liberalismo e a renovação do conceito e visão de liberdade:

A ideologia dos sistemas totalitários desacreditara por completo o liberalismo após a I Grande Guerra Mundial, emprestando-lhe acepção pejorativa, de que ainda nada pôde de todo desembaraçar-se. Mas essa tendência antiliberal investia, na verdade, contra um moinho de vento, pois o liberalismo, como "doutrina contra o Estado", morrera com a primeira fase do capitalismo. O que o século XX conhece, na pureza dos postulados em que se arrima o legítimo pensamento democrático, é um esforço ideológico de preservação da liberdade humana.

A inércia do Estado na solução das profundas desigualdades faz crescer o ideário socialista encabeçado pela ideia de contraponto ao liberalismo e ao capitalismo extremo, tomando para o Estado o dever de limitar a atuação dos agentes econômicos visando a garantir o bem-estar de todos os cidadãos, por vezes, até com extremos como comunismo ${ }^{13}$ e estatização absoluta.

Nascia, assim, o paradigma do Estado Social fortemente marcado pelas constituições do México (1917) e de Weimar (1919), com amplas previsões acerca de direitos sociais e de forte e expansiva intervenção estatal no ambiente econômico a fim de garantir direitos com exploração direta, inclusive, de bens e serviços. Com o Estado Social surge o reconhecimento de muitos dos direitos sociais, hoje existentes como garantia de rendimentos mínimos e de limites de jornada do trabalhador, o amparo a doentes, idosos e desempregados pelo organismo Estatal, além de todas as regras estabelecidas a fim de modificar a liberdade de funcionamento dos mercados.

Há diferenças importantes entre as Cartas do México e de Weimar. Inicialmente, é notório que a constituição alemã logra êxito em alcançar projeção na Europa e em todo mundo de escala imensamente superior à do México, mas não apenas isso, embora a Constituição

\footnotetext{
${ }^{12}$ Nesse sentido afirma Armando Castelar Pinheiro e Jairo Saddi (2006)

13 Há divergências quanto ao conceito de comunismo, sendo usualmente indicado como modelo de regime autoritário implantado em alguns países como Rússia, China e Cuba. Há quem conceitue comunismo, contudo, como uma etapa posterior ao socialismo na qual o próprio Estado poderia desaparecer, a sociedade estabelecer uma vida plenamente satisfatória em comunidade de comunhão de bens, força trabalho e interesses.
} 
Mexicana trouxesse aspectos progressistas e de preocupação com cunho social, mas não no bojo de mecanismos para efetivação de direitos, sobretudo no que diz respeito ao planejamento e organização da atividade econômica e da ingerência estatal, algo feito com bastante nitidez e de forma inovadora na Constituição de Weimar. (FERREIRA FILHO, 1990, p. 4).

Também é importante enfatizar a distinção entre Socialismo e Estado Social. Diversos são os conceitos e até classificações de socialismo existentes. De modo geral, tem-se o socialismo como modelo político de modificação de esferas de poder existente na lógica capitalista, trazendo o poder político para a classe do proletariado e promovendo a estatização da propriedade privada e dos meios privados de produção. Nesse sentido, Norberto Bobbio (2007, p. 1196):

\begin{abstract}
Em geral, o Socialismo tem sido historicamente definido como programa político das classes trabalhadoras que foram se formando durante a Revolução Industrial. A base comum das múltiplas variantes do socialismo pode ser identificada na transformação substancial do ordenamento jurídico e econômico fundado na propriedade privada dos meios de produção e troca, numa sociedade na qual: a) o direito de propriedade seja fortemente limitado; b) os principais recursos econômicos estejam sob o controle de classes trabalhadoras; c) a sua gestão tenha como objetivo promover a igualdade social (e não somente jurídica ou política) através de intervenção dos poderes públicos.
\end{abstract}

Diverge o paradigma do Estado Social por não defender, necessariamente, modificação tão profunda de sistema econômico. O Estado Social procura, de modo geral, dentro do modelo capitalista, garantir o mínimo existencial para os indivíduos, cabendo ao Estado o papel de prover acesso a determinados bens, em especial aos que mais necessitam, por não disponibilizarem de recursos econômicos para alcançá-los.

Paulo Bonavides (2007, p. 184) esclarece a necessidade da distinção e a impropriedade de confusão entre Estado Social e Estado Socialista, na medida em que enquanto este se opõe ao capitalismo, o mesmo não acontece com o paradigma social que propõe, tão somente, uma intervenção no modelo capitalista.

Nessa visão, compreende-se que o Estado Socialista ou Socialismo prega o fim do Capitalismo, ruptura e incorporação de novo regime, enquanto o Estado Social não se desvencilha do Capitalismo, podendo ser adotado, com maiores e menores projeções, em regimes democráticos, totalitários, republicanos e monárquicos, dadas versatilidade e adaptabilidade como destacadas. 
A principal falha do Estado social, contudo, é a dificuldade de alcance dos objetivos estabelecidos, gerando verdadeira frustração e sentimento de ausência de efetividade em suas determinações, como assevera MOTA (2011, p. 11).

Tanto é verdade, que se dissemina, no cenário jurídico, a classificação de algumas normas, inclusive constitucionais, que estabelecem direitos sociais como "normas programáticas" ${ }^{\prime 14}$ que podem, um dia, ser efetivadas pelo Estado, apenas e tão somente quando possível.

Há dois claros problemas decorrentes de Constituições marcadas pelo Paradigma Social: 1) como os direitos sociais nela contidos são efetivamente escolhidos? Ou seja, quais são deliberadamente imputados como obrigações estatais e quais são deixados de fora?; 2) corresponde ao possível boicote que a efetivação de direitos sociais pode sofrer, sobretudo direitos que se voltem para as camadas mais pobres, pela atuação e intervenção dos grandes detentores dos poderes econômico, político e ideológico. Com essa reflexão, questiona-se, até mesmo, a força normativa da Constituição, ou seja, vale mais o que se encontra no Texto Constitucional ou o que dele é extraído a partir da ação e do interesse dos chamados fatores reais de poder? (LASSALLE, 2001, p. 10).

Surge, em contraponto, ou também se pode afirmar, em evolução, o paradigma do Estado Democrático de Direito, que visa conferir efetiva legitimidade aos direitos instituídos e protegidos pelo legislador. Nesse paradigma, atualmente existente, tem-se, pois, como característica principal a existência de elementos do paradigma Liberal e do paradigma Social, diferenciando-se dos anteriores principalmente pelo fato de se estabelecer participação popular na escolha de direitos pela democracia.

Tradicionalmente, diante do exposto, apontam-se sistemas econômicos antagônicos socialismo x liberalismo, restando a este menção mais diretamente realizada quando se trata do aspecto de defesa da concorrência como se essa estrutura estatal fosse decorrência do liberalismo. Há, todavia, terceira via, pode-se dizer via de equilíbrio, modelo intervencionista em que se procura equilibrar liberdade com os interesses sociais. (RAMOS, 2015).

Além disso, o processo de integração entre as economias do mundo, conhecido como globalização, trata de fenômeno que acompanha o desenvolvimento da atividade econômica, certo de que teve início com as expedições de navegação, no período mercantilista, e se

\footnotetext{
${ }^{14}$ Paulo Bonavides (2013, p. 241) estabelece crítica à "programaticidade" de normas constitucionais, que seriam normas que não se concretizam, não saem da projeção teórica de um direito ideal dos cidadãos, mas impossível de realizar-se. Ao prevalecer esse viés eminentemente programático, se evidencia frustração da população que se vê diante de promessas não cumpridas e não alcançadas pelo Estado.
} 
desenvolve com a revolução industrial e a necessidade de se alcançar insumos e mão de obra barata, como também mercados de consumo maiores e ávidos, para a quantidade de bens produzidos em escala, no novo modelo capitalista. (FORGIONI, 2009).

\section{Ordem Econômica na Constituição de 1988}

Pela Constituição da República Federativa do Brasil de 05 de outubro de 1988 CRFB/88, a ordem econômica fundamenta-se nos arts. $170^{15}$ e seguintes, sendo clara a posição do constituinte de defesa e incentivo à livre iniciativa, à livre concorrência e à defesa do consumidor, entre os postulados, sendo os citados princípios basilares por expressa determinação constitucional. Mais adiante ${ }^{16}$, o legislador constituinte reitera a opção pela posição do Estado como regulador da economia e não como explorador direto da atividade econômica. Eros Roberto Grau (2004, p. 312) afirma que a ordem econômica na Constituição vigente é intervencionista, não se alinhando ao pensamento liberal ou à lógica de autorregulação do mercado.

É verdade que o sistema constitucional vigente no Brasil prevê muitas e variadas formas de intervenção, por vezes até exacerbadas, não se pode, contudo, defender que o ordenamento constitucional rejeita por completo o pensamento liberal, uma vez que a intervenção da economia é limitada, atuando o Estado como regulador do mercado.

A CRFB/88 é típico fruto do paradigma do Estado Democrático de Direito que busca mesclar perspectivas do ultrapassado paradigma de Estado Liberal e do Paradigma do Estado Social, sem, contudo, promover liberdade excessiva e desregulada, nem também estabelecer sem número de promessas de intenção sem que os mandamentos contem com efetividade. Há, nesse viés, clara conjunção dos melhores elementos dos paradigmas anteriores, sempre com foco na efetivação da liberdade e da livre iniciativa e no respeito aos direitos sociais.

Daí recorrente crítica, talvez, de contrariedade aos preceitos estabelecidos no capítulo da ordem econômica da CRFB/88 como um todo, na medida em que a Carta Constitucional

\footnotetext{
${ }^{15}$ Art. 170. A ordem econômica, fundada na valorização do trabalho humano e na livre iniciativa, tem por fim assegurar a todos existência digna, conforme os ditames da justiça social, observados os seguintes princípios: [...] IV - livre concorrência; V - defesa do consumidor; [...] Parágrafo único. É assegurado a todos o livre exercício de qualquer atividade econômica, independentemente de autorização de órgãos públicos, salvo nos casos previstos em lei.

${ }^{16}$ Art. 173. Ressalvados os casos previstos nesta Constituição, a exploração direta de atividade econômica pelo Estado só será permitida quando necessária aos imperativos da segurança nacional ou a relevante interesse coletivo, conforme definidos em lei.

Art. 174. Como agente normativo e regulador da atividade econômica, o Estado exercerá, na forma da lei, as funções de fiscalização, incentivo e planejamento, sendo este determinante para o setor público e indicativo para o setor privado.
} 
prevê, ao mesmo tempo, direito à propriedade privada e observância do princípio da função social da mesma, direito à livre iniciativa conjugado com o respeito ao meio ambiente, a proteção do consumidor e da livre concorrência, entre outros elementos limitadores.

A Constituição Federal de 1988 consagra a regulação da economia do mercado brasileiro, consagrando o regime de mercado organizado, numa postura liberal, por só admitir intervenção do Estado na coibição de abusos e preservação de livre concorrência, tendo como corolário defesa e incentivo à livre iniciativa, sendo certo, no entanto, que o liberalismo adotado se distancia do modelo liberal puro já apresentado, alinhando-se a uma visão claramente intervencionista, com presença e controle equilibrado do Estado, contemplando a economia de mercado e buscando a auto regulação da ordem econômica como cenário ideal, mas não afastando ou limitando excessivamente a presença do Estado.

Em relação aos serviços públicos essenciais, a Constituição Federal de 1988 permite a exploração da atividade de forma direta pelo Estado, prevendo, todavia, modalidades de concessão e permissão para tais atividades, em claro intuito de privilegiar a iniciativa privada: “Art. 175. Incumbe ao Poder Público, na forma da lei, diretamente ou sob regime de concessão ou permissão, sempre através de licitação, a prestação de serviços públicos."

A década de 90 contou com grandes avanços na regulamentação infraconstitucional voltada para regulação da economia. Nesse período, ocorreram as maiores privatizações, bem como a adoção de marco regulatório para os principais serviços públicos e mercados estratégicos. Data de 1990 a Lei 8.078, publicada em 11 de setembro, conhecido Código de Proteção e Defesa do Consumidor, que disciplina as relações de consumo e garante proteção efetiva do consumidor vulnerável. Pouco adiante, publica-se a Lei 8.884 de 30 de novembro de 1994, lei antitruste brasileira, posteriormente substituída pela Lei 12.529, de 30 de novembro de 2011. Ainda na década de 90, houve a edição de lei 9.279, de 14 de maio de 1996, que substitui o antigo Código de Propriedade Industrial e regula a proteção dos bens da propriedade industrial.

A CRFB/88 nasce de longo aprendizado histórico pelo qual o Brasil passa, após saída de período de exceção com a Ditadura Militar ${ }^{17}$. Trata-se de Constituição que mescla os aspectos positivos da doutrina liberal e da doutrina social, marcada pelo paradigma do Estado Democrático de Direito.

\footnotetext{
${ }^{17}$ O Brasil vivenciou um período de exceção ditatorial a partir de golpe e intervenção militar iniciada em 1964 e finda apenas em 1985 com a reabertura democrática e a convocação de Assembleia Nacional Constituinte a fim de elaborar a Constituição vigente. Esse período histórico voltará a ser abordado no capítulo 4.
} 


\section{Conclusão}

A figura do Estado, como responsável pela tutela e controle limitativo das vidas das pessoas, pressupõe a existência de uma legitimação do povo que escolhe e concorda (pelo menos, em tese) em sobrepor à figura estatal, em detrimento da própria vontade de autotutela, invariavelmente vinculada à noção de poder coercitivo, ou seja, o Estado, com a legitimação do povo, determina regras e fiscaliza o seu cumprimento, punindo os que as descumprirem.

Em razão desse poder indissociável da figura estatal, em vários momentos históricos, o Estado se revelou como um aparato que tende a se tornar autoritário, abusivo, portador de atos excessivos e que desrespeitam os interesses e direitos individuais. Nesse particular, surgem as constituições de $1^{\text {a }}$ geração, que seriam decorrentes do paradigma do estado liberal, incluindo-se como um dos principais elementos dessas cartas constitucionais a proteção à liberdade dos indivíduos em detrimento dos excessos estatais.

A liberdade ressoa no campo econômico, ganhando força a doutrina do laissez faire, encabeçada por Adam Smith, ou seja, da mínima ou nenhuma intervenção estatal, no campo econômico, permitindo-se o funcionamento dos mercados de forma autônoma, pela autorregulação. Nessa liberdade, acredita-se que a racionalidade humana conduzirá todos à busca de satisfação das necessidades pessoais o que, diante da existência de concorrência nos diversos pontos das relações mercadológicas, garante a maximização de bem-estar.

As interações, no campo econômico, ocorrem no mercado, ambiente comumente definido como local em que os agentes econômicos promovem trocas de excedentes, em busca da satisfação dos interesses pessoais. Pela lógica liberal, quanto maior a garantia de liberdade nos mercados, melhor e mais eficiente seu funcionamento.

A realidade, sob a institucionalização das constituições liberais, e do liberalismo no ambiente econômico, contudo, revelou-se diversa. Os mercados extremamente livres se apresentaram em ambiente adequado à ocorrência de falhas sistêmicas como colusão entre pretensos competidores e a formação de estruturas monopolísticas, o que contribuiu para construção e desenvolvimento de ambiente de extrema desigualdade e marginalização de grande parte da sociedade, sem acesso a bens de consumo primários.

Aliados à questão, alguns eventos acarretaram ainda maior fragilidade ao ideário liberal, as guerras mundiais e crise da bolsa de Nova York em 1929, contribuindo, assim, para fortalecimento da visão do paradigma do estado social, defensor de atuação estatal, sobretudo 
no campo econômico, para garantir a proteção dos interesses dos vulneráveis e para, inclusive, atuar como prestador de bens, serviços e direitos dos mais necessitados.

Difere o paradigma social a visão do socialismo que tem no campo teórico o maior expoente Karl Marx. O socialismo defende ruptura com o capitalismo e a adoção de novo modelo de produção, pela estatização de toda atividade econômica e suprimento estatal equitativo das necessidades dos indivíduos. O modelo socialista jamais chegou a ser adotado da forma teórica concebida, invariavelmente desencadeando em estruturas totalitárias e ditatoriais.

As constituições sociais não negam o capitalismo, apenas moldam vertentes intervencionistas no campo econômico e estabelecem, em seu bojo, um grande número de direitos, direitos econômicos, sociais e culturais, entretanto pecam as cartas constitucionais em não conceber adequadamente a forma e o custeio de prestação de direitos, de responsabilidade. Por razões lógicas, muitos dos direitos previstos no campo constitucional não conseguiram confirmação na prática, o que acarreta verdadeira frustração e insatisfação dos indivíduos, e cria a concepção das normas constitucionais programáticas que, embora funcionem como programa de intenções, não gozam de respaldo prático real, ou seja, estão previstas no texto constitucional, mas apenas para, um dia, se possível for, serem implantadas.

Modernamente, em resposta a essa frustração decorrente de constituições, sob o paradigma do estado social, surge o paradigma do estado democrático de direito, também de viés intervencionista, caracterizado por contar com figura estatal responsável pela prestação de direitos que, todavia, precisam passar pelo crivo de escolha democrática, a cargo da população que se submete aos termos constitucionais e, inclusive, financiará essa gama de atividades estatais.

Em via lateral, ganha força, nas últimas décadas, a "Análise Econômica do Direito" que defende o uso de elementos econômicos na análise de questões jurídicas, preocupando-se, sobretudo, com impactos da intervenção jurídica estatal, no domínio econômico e de como desenvolver visão de intervenção que produza um resultado eficiente. A AED conta com variações de pensamento e compreensão, tendo o trabalho destacado a escola de Chicago, mais influente, escola Austríaca, de forte cunho liberal, e a chamada Pós-Chicago que seria uma evolução da primeira escola.

A noção de eficiência econômica é controversa e se alia, pela concepção da escola de Chicago, à noção de maximização de riqueza e produção de bem-estar agregado, ou seja, a situação que, ao final, seja capaz de gerar maior volume de riqueza e bem-estar possível, é considerada eficiente. Essa noção de eficiência econômica e seu impacto no campo jurídico 
ainda são recentes no Brasil e carecem de modelagem nacional, de acordo com preceitos jurídicos constitucionais vigentes.

A Constituição Brasileira de 1988 é fruto do paradigma do Estado Democrático de Direito, e promove visão intervencionista no campo econômico, embora fundada na noção de garantia de liberdade para agentes econômicos até certa medida. Como fruto desse intervencionismo tem-se a figura do Sistema Brasileiro de Defesa da Concorrência - SBDC, regido pela Lei 12.529/11; e o Sistema Nacional de Defesa do Consumidor - SNDC, regido pela Lei 8.078/90.

Considerando a CRFB/88, a implantação da AED no ordenamento jurídico pátrio demanda observâncias dos preceitos constitucionais e inviabiliza a valorização extrema da noção de eficiência econômica em detrimento dos contornos jurídicos próprios e constantes desde a Constituição, norma e diretriz máxima a ser observada. É preciso construir uma identidade nacional para desenvolvimento de uma teoria brasileira da Análise Econômica do Direito que seja compatível com os preceitos econômicos e sociais da CRFB/88.

\section{Referências bibliográficas}

ANDRADE, José Maria Arruda de. Economicização do Direito Concorrencial. São Paulo: Quartier Latin, 2014.

BACHELARD, Gaston. A epistemologia. Rio de Janeiro: Edições 70, 1971.

BOBBIO, Norberto. Dicionário de política (1909). Tradução de Carmen C. Varrialle. 13. ed. Brasília: Universidade de Brasília, 2007.

BONAVIDES, Paulo. Do estado social ao estado liberal. São Paulo: Malheiros, 2007.

BONAVIDES, Paulo. Curso de direito constitucional. São Paulo: Malheiros, 2013.

BRASIL. Constituição (1988). Constituição da República Federativa do Brasil. Disponível em: <https://www.planalto.gov.br/ccivil_03/Constituicao/Constitui\%C3\%A7ao.htm>. Acesso em: 10 abr. 2017. 
COASE, Ronald. The firm, the market and the law. Chicago: Chicago University Press, 1990.

CRANE, Daniel A. Chicago, Post-Chicago, and Neo-Chicago. Review of How Chicago Overshot the Mark, v.76, n.4, p. 1911-1933, 2009. Disponível em: $<$ http://repository. law.umich.edu/cgi/viewcontent.cgi?article $=1060 \&$ context $=$ reviews $>$. Acesso em: $10 \mathrm{abr}$. 2017.

DEL MASSO, Fabiano. Direito Econômico. Rio de Janeiro: Elsevier, 2007.

FARINA, Elisabete. Prefácio. In: ZYLLBERSZTAJN, Décio; SZTAJN, Rachel (Org.). Direito \& economia. Rio de janeiro: Elsevier, 2005. p. 11-32.

FERREIRA FILHO, Manoel Gonçalves. Curso de Direito Constitucional. São Paulo: Saraiva, 1990.

FORGIONI, Paula A. A evolução do direito comercial brasileiro: da mercancia ao mercado. 5. ed. São Paulo: Revista dos Tribunais, 2009.

GICO JÚNIOR, Ivo Teixeira. Metodologia e epistemologia da análise econômica do Direito. Economic Analysis of Law Review, Brasília, v. 1, n. 1, p. 7-33, jan./jun. 2010.

GOLDBERG, Daniel Krepel. Poder de compra e política antitruste. São Paulo: Singular, 2006.

GRAU, Eros Roberto. A Ordem Econômica na Constituição de 1988. São Paulo: Malheiros, 2004.

HOVENKAMP, Herbert. Federal Antitrust Policy: the law of competition and its practice. St. Paul: THOMSON, 2005.

KALLAY, Dina. The Law and economics of antitrust and intellectual property: na Austrian approach. Cheltenham: Edward Elgar Publishing, 2004. 
KRAUSE, Martin. Analisis económico del derecho - aplicación a fallos judiciales. Buenos Aires: La Ley, 2006.

LASSALLE, Ferdinand. A essência da constituição. 6. ed. Rio de Janeiro: Lumen Juris, 2001 .

MAGALHÃES, José Luis de. Direito Constitucional. Belo Horizonte: Mandamentos, 2000.

MOTA, Márcio. Paradigma contemporâneo do Estado Democrático de Direito: póspositivismo e judicialização da política. In: MOTA, Maurício; MOTTA, Luiz Eduardo. O estudo democrático de direito em questão: teorias críticas de judicialização da política. Rio de Janeiro: Elsevier, 2011. p. 03-21.

PINHEIRO, Armando Castelar; SADDI, Jairo. Direito, economia e mercados. Rio de Janeiro: Campus Elsevier, 2006.

POPPER, Karl. A lógica da Pesquisa científica. São Paulo: Cultrix, 1993.

RAMOS, André Luiz Santa Cruz. Os fundamentos contra o antitruste. Rio de Janeiro: Forense, 2015.

SALAMA, Bruno Meyerhof. O que é "Direito e Economia"? In: TIMM, Luciano Benetti (Org.). Direito \& Economia. Porto Alegre: Livraria do Advogado, 2008.

SALAMA, Bruno Meyerhof. A História do Declínio e Queda do Eficientismo na Obra de Richard Posner. 2012. Disponível em: $<$ https://works.bepress.com/bruno_meyerhof_salama /35/>. Acesso em: 10 abr. 2017.

SANDEL, Michael. Justiça: o que é fazer a coisa certa. Rio de Janeiro: Civilização brasileira, 2014.

SOUSA, Nali de Jesus de. Uma Introdução à História do Pensamento Econômico. 2009.

Disponível em: <http:/www.nalijsouza.web.br.com/downloads/outrostextos/ desenvolvimento/introd_hpe.pdf $>$. Acesso em: 19 jun. 2016. 
STIGLITZ, Joseph E.; WALSH, Carl E. Introdução à Economia. Tradução de Maria José Cyhlar Monteiro. Rio de Janeiro: Campos, 2003.

SZTAJN, Rachel. Law \& Economics. In: ZYLLBERSZTAJN, Décio; SZTAJN, Rachel (Org.). Direito \& economia. Rio de janeiro: Elsevier, 2005. p. 11-32. 


\title{
AS PATENTES DE INVENÇÕES NA LEGISLAÇÃO BRASILEIRA COMO INTERESSE SOCIAL E DESENVOLVIMENTO ECONÔMICO E TECNOLÓGICO DO PAÍ́S
}

\author{
Querino Mallmann
}

Universidade Federal de Alagoas (UFAL)

\section{Resumo}

As patentes de invenções são privilégios exclusivos e temporários concedidos pelo Estado aos inventores. É um Título de Propriedade que o Estado concede àqueles que oferecem a sociedade um produto ou um processo novo, para que a mesma possa usufruir dos benefícios da descoberta. Constituem-se de um Título de Propriedade conferido ao inventor para que este revele o segredo da invenção, em contrapartida o Estado lhe assegura um privilégio exclusivo de poder explorá-la economicamente por um lapso temporal (mínio 10, máximo 20 anos pela atual LPI), excluindo terceiros, caindo depois em domínio público. O princípio básico da patente consiste na socialização do conhecimento através da descrição minuciosa da invenção, viabilizando o desenvolvimento tecnológico, e concomitantemente, recompensando o inventor pela novidade, atividade inventiva e aplicação industrial.

Palavras-chave: Patentes de Invenções, Propriedade Industrial, Desenvolvimento Econômico, Desenvolvimento Tecnológico, Inclusão social;

\section{Abstract/Resumen/Résumé}

Las patentes de invenciones son privilegios exclusivos y temporales concedidos por el Estado a los inventores. Es un título de propiedad que el Estado concede a aquellos que ofrecen a la sociedad un producto o un proceso nuevo, para que la misma pueda disfrutar de los beneficios del descubrimiento. Se trata de un Título de Propiedad conferido al inventor para que éste revele el secreto de la invención, en contrapartida el Estado le asegura un privilegio exclusivo de poder explotarla económicamente por un lapso temporal (mínimo 10, máximo 20 años por la actual LPI), excluyendo a terceros, cayendo después en dominio público. El principio básico de la patente consiste en la socialización del conocimiento a través de la descripción minuciosa de la 
invención, viabilizando el desarrollo tecnológico, y concomitantemente, recompensando al inventor por la novedad, actividad inventiva y aplicación industrial.

Keywords/Palabras-claves/Mots-clés: Patentes de Invenciones, Propiedad Industrial, Desarrollo Económico, Desarrollo Tecnológico, Inclusión social;

\section{Introdução}

Historicamente os direitos sobre bens intelectuais nunca tiveram uma importância tão grande como na atualidade. Pelo ordenamento jurídico brasileiro, sua proteção começou pelas invenções, a princípio como privilégio real, para após se tornar privilégio legal concedido temporariamente pelo Estado, estendendo-se depois para as marcas de indústria e de comércio, ao nome comercial, firma ou razão social, abrangendo, por último, a proteção legal também dos títulos do estabelecimento, insígnias, modelos de utilidade, desenhos industriais, sinais e expressões de propaganda e as marcas de serviço.

Pela Constituição brasileira de 1828, protegia-se o inventor, mas não havia nenhuma punição caso houvesse alguma violação à propriedade industrial $(\mathrm{CF} / 1824$, art. 179, § 26).

Somente em 1830, através da Lei Penal, veio a se proibir "imprimir, gravar, litografar ou introduzir quaisquer escritos ou estampas que tivessem sido feitos, compostos ou traduzidos por cidadãos brasileiros, enquanto estes viverem, e 10 (dez) anos depois de sua morte, se deixarem herdeiros". Previu-se algumas medidas tendentes a reprimir as violações ao direito da propriedade intelectual, como objeto de proteção penal (art. 345-350), mas ainda muito aquém da proteção que é oferecida atualmente.

Todas as Constituições Brasileiras sempre mantiveram a proteção à propriedade industrial, com exceção da Constituição de 1937, que foi uma exceção, devido ao Estado Novo que se vivia no Brasil na época. Assim, as demais Constituições sempre trazem um dispositivo sobre a matéria: Constituição de 1924, art. 179, § 26; Constituição de 1891, art. 72, § 26; Constituição de 1934, art. 113, inciso 20; Constituição de 1946, art. 150, § 2, Constituição de 1967, art. 153, § 25; Constituição de 1988, art. 5 , incisos XXIX, in verbis: “A lei assegurará aos autores e inventores industriais privilégio temporário para sua utilização, bem como proteção às criações industriais, à propriedade de marcas, aos nomes de empresa e a outros signos distintivos, tendo em vista o interesse social e o desenvolvimento tecnológico $e$ econômico do País", remetendo a regulamentação sobre a matéria para a norma infraconstitucional. 
Assim, a questão que motivou a elaboração da nova Lei de Propriedade Industrial (LPI) foi a proibição que existia na Lei anterior (Lei 5.772/71) sobre a não concessão de Patentes sobre produtos farmacêuticos (os fármacos) e alimentícios, pois até 1996 (advento da lei 9.279), o Brasil (leia-se Instituto Nacional da Propriedade Industrial-INPI) não concedia concessão de Patentes para produtos farmacêuticos e alimentícios, o que sempre motivou uma forte pressão internacional, principalmente pelos EUA os maiores detentores do Royalties sobre estas patentes. A inclusão da concessão de patentes nessa área foi consequência da pressão norte-americana, da OMC, do Comércio Internacional e também do ADPIC/TRIPs, no qual os norte-americanos também pressionaram muito.

Inventar pressupõe criar algo novo, inédito, algo que antes não era conhecido, de tal forma que o direito brasileiro não garante exclusividade ao conhecimento e às descobertas, mas tão-somente às invenções ou aos inventos que atendam aos requisitos da patenteabilidade: $a$ ) atividade inventiva, b) novidade, c) aplicação industrial. Novo é tudo aquilo que ainda não está no "estado da técnica" (art. 11), sou seja, tudo aquilo que ainda não foi tornado público, é a "novidade absoluta" e não somente a relativa. $\mathrm{O}$ ordenamento jurídico brasileiro exige a "novidade absoluta" para a concessão da carta-patente. Alguns, no entanto, tentam ensinar que também seria patenteável as invenções de "novidade relativa", ou seja, a questão envolvendo as "Patentes Pipeline"; para estes, além da previsão legal (art. 230 da atual LPI), as "Patentes Pipeline" preencheriam os requisitos da "novidade relativa", ou seja, não foram levados à registro na época, pois a lei anterior (lei 5.772/71 proibida as patentes de medicamentos no Brasil, logo haveria a novidade econômica (não utilização industrial em certo limite territorial) e a novidade comercial (não comercialização, não colocação no mercado). Embora a novidade absoluta não está expressa de forma literal no art. $5^{\circ} \mathrm{da} \mathrm{CF} / 88$, está na norma infraconstitucional (art. $8^{\circ}$, da Lei 9.279/96), daí a celeuma envolvendo a inconstitucionalidade ou não do art. 230 da Lei 9.279/76 sobre a concessão da "Patentes Pipeline".

\section{As controvérsias sobre as primeiras patentes de invenções}

As primeiras patentes de invenções que se tem notícias, àquela com privilégio real, conforme nos ensina Rubens Requião, datam de 1311, concedida pelo Rei Eduardo III, da Inglaterra, sendo encontrada outra em 1561, para o fabrico de salitre, e em 1602, na Câmara dos Comuns. Sendo que o princípio do privilégio real e mais tarde do direito natural teria 
vigorado até 1852 , quando foi promulgada pela primeira vez uma lei normativa ${ }^{1}$. Já segundo Eduardo J. Vieira Manso, o primeiro privilégio teria sido concedido pelo Senado de Veneza, em 1449, para a edição das Cartas de Cícero. Porém, há quem aponte que os primeiros privilégios teriam surgidos também na Itália, mas em 1495, quando o mesmo Senado de Veneza os concedeu ao Editor Aldo Manúcio, para publicar as Obras de Aristóteles ${ }^{2}$. Outros, porém, ainda apontam que as primeiras patentes de que se tem notícia seriam de 1421 em Florença, na Itália, com Felippo Brunelleschi e seu dispositivo para transportar mármore, e em 1449 na Inglaterra com John de Utynam, ganhando o monopólio por 20 anos sobre um processo de produção de vitrais; sendo que a primeira lei de patentes do mundo teria sido promulgada em 1474 em Veneza, já com a visão de proteger com exclusividade o invento e o inventor, concedendo licença para a exploração, reconhecendo os direitos autorais e sugerindo regras para a aplicação no âmbito industrial ${ }^{3}$. Já para Patrícia Aurélia del Nero, a primeira Carta Patente teria sido concedida na cidade de Veneza à Giovanni de Spira através de um Decreto de 18/09/1469, e estaria relacionada à imprensa, concedendo-lhe um direito exclusivo da arte de impressão naquele território, impondo sanções aos eventuais usurpadores ${ }^{4}$.

Seja como for ou de qual País, Rei, Monarca teria concedido o primeiro privilégio industrial ou monopólio exclusivo de explorar temporariamente um invento, sabemos que ao longo do tempo, as invenções ou "engenhocas", como inicialmente eram conhecidas, desempenharam ao longo do tempo, um importante papel para levar a indústria a um nível tão elevado e sofisticado como se encontra na atualidade, contribuindo para o progresso das ciências e da tecnologia.

\subsection{As Patentes de Invenções no Brasil}

A Constituição Brasileira confere aos Direitos da Propriedade Intelectual o status de Direito Fundamental, pois está inserido no art. $5^{\circ}$ da $\mathrm{CF} / 88$, encontrando-se também vinculado a outras prescrições constitucionais de grande relevância, como é o caso do capítulo que trata sobre "Ciência e Tecnologia" (CF/88, art 218), da livre concorrência (art. 170, IV), da função social da propriedade art. 170, III). Para que o Estado possa conceder uma Carta-Patente é

\footnotetext{
${ }^{1}$ REQUIÃO, Rubens. Curso de Direito Comercial. $27^{\mathrm{a}}$ ed., 2007, vol. 1, p. 312

${ }^{2}$ GANDELMAN, Henrique. De Gutenber à Internet: direitos autorais na era digital. Rio de Janeiro, 1997, Editora Record, pág. 29.

${ }^{3}$ MANSO, Eduardo J. Vieira. O que é Direito Autoral. $2^{\text {a }}$ edição, São Paulo, Editora Brasiliense, 1992, p. 13

${ }^{4}$ Del Nero, Patrícia Aurélia. Propriedade Intelectual: a tutela jurídica da biotecnologia. SP, RT, 1998, p. 30
} 
necessário que o inventor prove que sua invenção preenche os três requisitos básicos: $a$ ) atividade inventiva; b) novidade e c) aplicação industrial. Além do mais as patentes devem prever a existência de duas finalidades específicas: o "interesse social" e "desenvolvimento tecnológico e econômico do País" - CF/88, art. 218.

No Brasil, a primeira lei de patentes independente foi sancionada em 28 de agosto de 1830 por D. Pedro I, tratando-se de uma regulamentação do mandamento inscrito na Constituição de 1824 , art. $179, \mathrm{n}^{\circ} 26$, sendo que os privilégios seriam concedidos por prazos variáveis, de cinco a vinte anos; o período de proteção dependendo do entendimento quanto à utilidade do invento". A economia brasileira, que havia passado a girar em torno do pólo cafeeiro, fez surgir, por exemplo, 209 patentes concedidas no período 1830-91. Dessas, 41 referiam-se a máquinas descascadoras, deixando a impressão de que o problema principal estava no descascar dos grãos de café; a seguir 31 patentes de aparelhos secadores; os maquinismos beneficiadores, de um modo geral, somavam 21 patentes, enquanto os aparelhos ventiladores alcançavam a média de 19 patentes; Em relação às marcas, foi somente em 1875, por força da Lei 2.682, que surge o primeiro instituto de proteção às marcas comerciais. Diferentemente das patentes, em que o Estado sempre tomou iniciativas, visando estimular o ímpeto criativo, a proteção para as marcas só surgiu depois que interesses comerciais concretos foram prejudicados pela inexistência de legislação específica.

O ALVARÁ DE $1^{\circ}$ DE ABRIL DE 1808, de D. João VI, expedida por Dom Pedro I (?...) também já dispunha alguma coisa sobre a Propriedade aos Direitos de Inventores: "§ VI - Sendo muito conveniente que os inventores e introdutores de alguma nova máquina e invenção gozem do privilégio exclusivo além do benefício que possam ter ao favor pecuniário, ordeno que todos os que tiverem neste caso apresentem o plano de seu novo invento à Real Junta de Comércio e que esta, reconhecendo a verdade e o fundamento dele, lhes conceda o privilégio por 14 anos, ficando obrigada a publicá-los depois, para que no fim desse prazo, toda a Não goze o fruto dessa inovação".

Segundo Marcelo Dias Varella, a primeira Lei de Patente Brasileira foi de 1830, segundo à qual "eram concedidas gratuitamente, pagos apenas o selo e o feitio, cabendo ao interessado provar por modelos, planos e desenhos, descrever todo o processo e depositar tudo no arquivo público. A duração do privilégio era de 5 (cinco) a 20 (vinte) anos. A violação dos direitos era reprimida com uma pena de multa equivalente a 1/10 do valor dos produtos fabricados, além da perda dos mesmos" ${ }^{\text {. }}$. Hoje a Constituição Brasileira e a norma infra-

\footnotetext{
${ }^{5}$ VARELLA, Marcelo Dias. Propriedade Intelectual de setores emergentes: biotecnologia fármacos e informática - de acordo com a Lei n. ${ }^{\circ}$ 9.279/96. SP, Atlas, 1996, p. 32
} 
constitucional protegem as patentes de invenções e os modelos de utilidade conforme dispõem o art. 40, da Lei 9.279/96: “A patente de invenção vigorará pelo prazo de 20 (vinte) anos, e a de modelo de utilidade pelo prazo 15 (quinze) anos contados da data de depósito e não será inferior a 10 (dez) anos para a patente de invenção e a 7 (sete) anos para a patente de modelo de utilidade, a contar da data de concessão, ressalvada a hipótese de o INPI estar impedido de proceder ao exame de mérito do pedido, por pendência judicial comprovada ou por motivo de força maior.

\subsection{Escritório de Patentes do Brasil}

Até 1970, a repartição encarregada de conceder os privilégios e efetuar os registros era o antigo Departamento Nacional da Propriedade Industrial (DNPI), extinto pela Lei $\mathrm{n}^{\circ}$. 5.648, de 11 de dezembro de 1970, em cujo lugar foi criado o Instituto Nacional da Propriedade Industrial (INPI), sob a forma de autarquia federal, com sede no Rio de Janeiro.

Além das antigas atribuições do extinto Departamento (DNPI), de proteger a propriedade industrial pela concessão do privilégio e de registro, a nova lei indica que o Instituto tem por finalidade principal executar, no âmbito nacional, as normas que regulam a propriedade industrial, tendo em vista a sua função social, econômica, jurídica e técnica, adotando, com vistas ao desenvolvimento econômico do País, medidas capazes de acelerar e regular a transferência de tecnologia e de estabelecer melhores condições de negociação e utilização de patentes, cabendo-lhe ainda pronunciar-se quanto à conveniência da assinatura, ratificação ou denúncia de convenções, tratados, convênios e acordos sobre propriedade industrial ${ }^{6}$.

Atualmente o INPI atua na concessão do privilégio de Invenção, de Modelo de Utilidade, de Modelo Industrial e do Desenho Industrial, mas ao mesmo tempo, que assim procede, implicitamente promove o respectivo registro. No que se refere à Marca de indústria, de Comércio e de Serviços, de Expressões ou Sinais de Propaganda, não ocorre concessão de privilégio, mas simplesmente o registro, que assegura o seu uso monopolístico. Tanto um como outro registro não são obrigatórios. O registro da invenção ou da marca são eminentemente facultativos. O Titular do direito de invenção pode não se interessar em obter a patente

\footnotetext{
${ }^{6}$ REQUIÃO, Rubens Curso Direito Comercial. $19^{a}$ ed., vol. 1, ed. Saraiva, 1989, p. 121
} 
respectiva, mantendo assim em absoluto sigilo o seu invento; o Titular de uma Marca pode não requerer o seu registro e usá-la desembaraçadamente. Em um como em outro caso, o inventor ou o dono da marca se situam fora da tutela oferecida pelo Estado ao seu direito, sujeitandose a ver o invento revelado ou a marca usada por terceiro, não tendo contra isso a quem reclamar. O Código da Propriedade Industrial disciplina, entretanto, o processo administrativo da concessão da patente de invenção e o registro da marca. Patente é o título, o certificado da concessão do privilégio concedido pelo Estado. Profundas alterações o novo Código imprimiu ao processo administrativo, com o propósito de aligeirá-lo, dele afastando os entraves burocráticos, facilitando a concessão do privilégio ou do registro, tendo em vista os altos interesses do desenvolvimento econômico do País.

Para que o Estado (leia-se aqui INPI) possa conceder uma Carta-Patente é necessário que o inventor prove que sua invenção preenche os três requisitos básicos: a) atividade inventiva; b) novidade e c) aplicação industrial. Além do mais as patentes devem prever a existência de duas finalidades específicas: o "interesse social" e "desenvolvimento tecnológico e econômico do País" - CF/88, art. 218. Mas também não adianta inventar uma patente e não explorá-la. O Brasil protege a patente de quem primeiro depositou (Teoria do "First do file"), enquanto que os EUA proteges a patente de quem primeiro a inventou ou primeiro a explorou (Teoria do "First do invent"). No entanto, se a patente for concedida a quem não possui os direitos sobre a invenção da patente, poderá ser declarada nula ou ter sua propriedade reivindicada pelos legítimos detentores dos direitos através de ação de Adjudicação de Patentes ${ }^{7}$.

O Processo de nulidade pode ser administrativo ou Judicial; No processo administrativo, o prazo é de até 06 meses da data da concessão, vide art. 50, sendo que o titular será intimado para se manifestar no prazo de 60 dias. Após, o INPI publicará a decisão para conhecimento de terceiros. (Para Desenho Industrial, o prazo de poder solicitar nulidade administrativa é de até 05 anos da concessão do registro, vide art. 113; Marcas, até 180 dias contados da data da expedição do certificado de registro, vide art. 168; Já o Processo Judicial, de nulidade pode poderá ser proposta a qualquer tempo da vigência da patente, pelo INPI ou por qualquer pessoa com legitimo interesse, art. 56. (Para Desenho Industrial, vide art. 118, 56 e 57; Marcas, vide art. 173). A ação de nulidade de patente será ajuizada no foro da Justiça

\footnotetext{
${ }^{7}$ Sato, Priscila Kei. “O Instituto Nacional da Propriedade Intelectual nas Ações de Nulidade e de Adjudicação: parte ou assistente?" In: DIDIER Jr., Fredie; WAMBIER, Teresa Arruda Alvim (Coords.). Aspectos Polêmicos e Atuais sobre os Terceiros no Processo Civil e Assuntos Afins. SP, RT, 2004, p. 781
} 
Federal e o INPI, quando não for autor, intervirá no feito (arts 57 e 175). A nulidade da patente poderá ser arguida, a qualquer tempo, como matéria de defesa (art. 56, parág. $1^{\circ}$.). O processo de nulidade prosseguirá ainda que extinta a patente (ART. 51, PARÁG ÚNICO). O prazo para resposta do réu (titular da patente) será de 60 dias. Após decisão, o INPI publicará a decisão para conhecimento de terceiros

O Processo de nulidade pode ser administrativo (até seis meses da data de concessão) ou Processo judicial de nulidade (em qualquer época). O processo de nulidade prosseguirá ainda que extinta a patente (ART. 51, PARÁG ÚNICO). A ação de nulidade também poderá ser proposta a qualquer tempo da vigência da patente, pelo INPI ou por qualquer pessoa com legitimo interesse (art. 56). A nulidade da patente poderá ser arguida, a qualquer tempo, como matéria de defesa (art. 56, parág. $1^{\circ}$.). A ação de nulidade de patente será ajuizada no foro da Justiça Federal e o INPI, quando não for autor, intervirá no feito (arts 57 e 175).

Para alguns autores, como Priscila Kei Sato e Lélio Denicoli Schimidt, o INPI estaria atuando como litisconsorte passivo necessário, isto é, como parte, e não como simples assistente, posto que o caráter coativo, da imposição legal do INPI de ter que intervir no feito, é de todo incompatível com o caráter voluntário que caracteriza a assistência ${ }^{8}$. O mesmo entendimento já foi esposado pelo $\mathrm{TRF} / 2^{\mathrm{a}}$ Região, por intermédio de sua $5^{\mathrm{a}}$ Turma, que em julgamento do AgIn 9202086737, de 18/05/1999, restou assim ementado: “O INPI, nas ações destinadas a anular registro de marca e patentes, é parte autônoma e não mero assistente; a ação de nulidade de registro há que ser proposta contra o titular do registro, tendo o INPI como co-réu, já que é a autarquia responsável pela concessão do registro de marcas e patentes". Além disto, o INPI não ostenta interesse específico na vitória de qualquer das partes, mas atuaria, isto sim, na defesa de um interesse próprio, uma vez que é um ato de sua lavra que está sendo alvo de impugnação, uma vez o que se pleiteia em juízo é justamente a desconstituição de um ato por ele emitido, praticado? .

\footnotetext{
${ }^{8}$ SCHIMIDT, Lélio Denicoli. “O INPI nas Ações de Nulidade de Marcas ou Patentes: assistente litisconsorte ou fiscal da lei? In Revista da ABPI, São Paulo, n. 26, p. 29-41, jan./fev. 1997, p. 36-3.

${ }^{9}$ SATO, Priscila Kei. O Instituto Nacional da Propriedade Intelectual nas Ações de Nulidade e de Adjudicação: parte ou assistente? In: DIDIER Jr., Fredie; WAMBIER, Teresa Arruda Alvim (Coords.). Aspectos Polêmicos e Atuais sobre os Terceiros no Processo Civil e Assuntos Afins. SP, RT, 2004, p. 799-800, citado tb. no paper do Danilo Vital de Oliveira, sobre DPI, pág. 7.
} 


\section{Critérios para concessão de patentes de invenções}

Novo é tudo aquilo que ainda não está no "estado da técnica", sou seja, tudo aquilo que ainda não foi tornado público, é a "novidade absoluta" e não somente a relativa. $\mathrm{O}$ ordenamento jurídico brasileiro exige a "novidade absoluta" para a concessão da carta-patente. Alguns, no entanto, tentam ensinar que também seria patenteável as invenções de "novidade relativa", ou seja, a questão envolvendo as "Patentes Pipeline"; para estes, além da previsão legal (art. 230 da atual LPI), as "Patentes Pipeline" preencheriam os requisitos, pois haveria a novidade relativa, ou seja, não foram levados à registro na época, pois a lei anterior (lei 5.772/71 proibida as patentes de medicamentos, logo haveria a novidade econômica (não utilização industrial em certo limite territorial) e a novidade comercial (não comercialização, não colocação no mercado). Portanto, será considerada nova quando "até a data do depósito do pedido de patente, não tiver sido depositada, patenteada, divulgada ou explorada no país, divulgada ou explorada no estrangeiro". ${ }^{10}$

Vale a pena delimitar as tênues diferenças entre novidade e originalidade. Sendo essa, uma qualidade adquirida no momento da concepção do objeto, sendo o exato momento que ele passa de desconhecido para conhecido no íntimo de uma pessoa. Assim sendo, uma ideia pode até ser original e ao mesmo tempo pode não ser nova, pois, como dito, a novidade está relacionada a qualquer meio de divulgação conhecida, já a originalidade, relaciona-se unicamente ao foro íntimo do descobridor. ${ }^{11}$

Para ser patenteável, a invenção, além de não ser compreendida no estado da técnica (novidade), não pode derivar de forma simples dos conhecimentos nele reunidos." O inventor deverá demonstrar que chegou àquele resultado novo em decorrência específica de um ato de criação seu. Serve o requisito para distinguir a invenção de uma mera descoberta, de modo que $\mathrm{o}$ direito de propriedade protege o inventor, mas não o mero descobridor ${ }^{12}$.

Os Estados Unidos possuem uma política diferente dos demais países e a favor do patenteamento também das descobertas. O atual Código de Patentes dos EUA possibilita que tanto as "invenções" como as meras "descobertas" poderão ser objeto de patenteamento, desde que "novos" e que "melhorem a sua utilidade". O primeiro julgamento neste sentido foi o caso “Parker v. Flook”, pela Suprema Corte norte-americana, onde foi concedida a Patente de

\footnotetext{
${ }^{10}$ Del Nero, Patrícia Aurélia. Propriedade Intelectual: a tutela jurídica da biotecnologia. SP, RT, 1998, p. 26-27

${ }^{11}$ COELHO, Fábio Ulhoa. Curso de direito comercial: direito de empresa. $1^{\circ}$ ed. São Paulo: Saraiva, 2010. Vol.1, pp. 153-154.

12 idem
} 
Invenção a um inventor, cujo pedido estava assentado na descoberta de um alarme cuja única distinção de outros alarmes já existentes no mercado era uma fórmula matemática que o viabilizava, razão pela qual não era uma invenção e sim uma descoberta, já existente no estado da arte. Neste caso, a discussão envolvendo o critério de utilidade foi central. A Suprema Corte norte-americana estabeleceu que os requisitos da "novidade" e da "não-obviedade" não eram critérios úteis para distinguir uma invenção de uma descoberta. (Caso Parker v. Flook. 437 U.S. 584 United States Supreme Court - Estados Unidos - $1978^{13}$.

O atual posicionamento dos EUA é no sentido de tomar como fundamento o grau de esforço da atividade humana em desenvolver ou, simplesmente, modificar alguma coisa até então não descoberta, mas que seja compatível com a produção industrial. Seguindo esses novos paradigmas, a legislação norte-americana considera patenteável o invento ou a descoberta que cumpra os seguintes requisitos: o invento não pode ser óbvio; deve ser novo; e útil à aplicação industrial. (MORAES, Rogério. Algumas polêmicas envolvendo a utilização de células-tronco embrionárias no Brasil: um desafio à inovação jurisdicional. 2011. Rio de Janeiro.

A legislação norte-americana, foi aos poucos, sendo reformada, abandonando assim a chamada doutrina do "product-of-nature doctrine", que estava baseada no princípio que para alguém poder obter uma Patente de Invenção, o objeto não poderia existir previamente na natureza. Foram aos poucos abandonando esta doutrina para viabilizar o patenteamento das “descobertas", tornando-se pioneiras neste entendimento ${ }^{14}$.

Assim, na medida em que a legislação brasileira elenca como requisitos intrínsecos da patente: a "invenção", "novidade" e "aplicabilidade industrial"; a legislação dos EUA admite como patenteáveis tanto a descoberta como a invenção, podendo ser patenteada tanto uma como a outra. Há naquele sistema, homenagem do requisito da utilidade industrial em detrimento da invenção. Para essa legislação, basta que o objeto da patente seja uma invenção ou descoberta de algo não óbvio e novo, mas que tenha utilidade industrial, não precisando ser, necessariamente, uma invenção.

Não por coincidência que o primeiro caso de patenteamento de seres vivos ocorreu também nos EUA no conhecido caso de Diamond v. Chakrabarty. Em 1980, o United States Patent and Trademark Office (USPTO) negou à General Electric Company o patenteamento de uma bactéria modificada geneticamente para degradar óleo cru. A empresa interessada recorreu à Suprema Corte americana que julgou procedente a solicitação. Foi o marco para que diversos

\footnotetext{
${ }^{13}$ Disponível em: http://supreme.justia.com/us/437/584/case.html. Acessado em 10/12/2012.

${ }^{14}$ FERNANDES, Marcia Santana. Uma abordagem jurídica e bioética sobre as patentes envolvendo célulastronco humanas. Rio de Janeiro: Forense, 2009.
} 
outros micro-organismos transgênicos fossem patenteados mundo afora. Como se explica isto? Constata-se que a legislação norte americana, bem como, os julgados desse país, optaram pela permissão do patenteamento das descobertas que sofressem a ação humana, visando à transformação, à modificação ou à cópia do existente. O sistema lá adotado tem o viés de homenagear a criatividade e o esforço humano desprendidos, mesmo que na descoberta, mas desde que com o intuito à industrialização. ${ }^{15}$

A legislação dos EUA permite o registro de patentes de produtos ou de processos de células tronco embrionárias e adultas, sem que se tenha, a princípio, nenhum impedimento legal. O Código de Patentes daquele país - Patent Act - em seu capítulo 35, parágrafo 101, define que tanto as invenções como as descobertas poderão ser objeto de patenteamento. Em 2001, foram outorgadas naquele país, mais de 727 patentes de células tronco adultas, e atualmente estima-se que mais de mil patentes relacionadas às tecnologias de células tronco tenham sido concedidas pela USPTO. Em menores proporções, já foram patenteadas nos EUA mais de 124 linhagens de células tronco embrionárias humanas e não humanas ${ }^{16}$.

O percussor nesta corrida pelo patenteamento de células-tronco de primatas e de humanos foi o pesquisador James Thomson, que desenvolve suas pesquisas na Universidade de Wisconsin. (...) Por sua vez, esta fundação criou uma subsisdiária, Wisconsin Cell Company (WiCell), hoje responsável por todos os assuntos relacionados à comercialização e à distribuição das 60 linhagens de células-tronco que têm o seu uso permitido nos Estados Unidos. As referidas patentes desenvolvidas por Thompson têm sido motivo de calorosos debates tantos nos EUA como internacionalmente, pois essas patentes abrangem todas as células tronco-embrionárias humanas e também o método utilizado por James Thompson para proliferá-las. De forma sucinta, temos que quase todas as pesquisas envolvendo estas células e os respectivos métodos terão de ter, nos EUA e em outros países, em tese, o devido licenciamento de um único titular da patente.

No que concerne às possibilidades jurídicas das patentes envolvendo células- tronco, transcrevemos as palavras de Cármen Lúcia C. Brotas: "No que diz respeito especificamente a células humanas identifica-se a possibilidade de patenteamento na Austrália, com exceção das células totipotentes ou células capazes de dar origem a um ser humano; na China, exceto células-tronco embrionárias e o corpo humano em seus vários estágios de formação e de desenvolvimento; na Comunidade Europeia, com exceção das células germinativas, bem como

\footnotetext{
${ }^{15}$ FARIA, Carmen Rachel Scavazzini Marcondes. Patentes biológicas. 2001.

${ }^{16}$ FERNANDES, Marcia Santana. Uma abordagem jurídica e bioética sobre as patentes envolvendo célulastronco humanas. Rio de Janeiro: Forense, 2009.
} 
processo de geração de quimeras de células germinativas ou células totipotentes humanas e animais; nos Estados Unidos, desde que seja uma linhagem celular humana pluripotente isolada ou purificada; e no Japão"17.

\section{As patentes de invenções vs medicamentos genéricos}

As patentes de invenções sobre fármacos, sempre chamou muita atenção, pois são uma das patentes que geram lucros astronômicos para os laboratórios farmacêuticos, mas quando caem em domínio público, suas vendas despencam vertiginosamente, principalmente no primeiro ano, quando entram no mercado os genéricos, os de marca, chegam a cair em torno de 65\%. Fármacos destinados ao aparelho cardiovascular são os mais afetados pelo sucesso das marcas brancas, segundo estudo que analisou o volume de vendas dos medicamentos entre 2003 e 2012; Sempre que um medicamento de marca deixa de estar protegido pela sua patente, há vários laboratórios que aproveitam esta janela de oportunidade para lançar no mercado versões genéricas do mesmo, as quais, por imposição legal, têm de ser 50\% mais baratas que o fármaco original.

Com os chamados medicamentos de marca branca a ganharem cada vez mais peso, torna-se especialmente visível o impacto que têm ao chegar ao mercado: só no primeiro ano os medicamentos de marca perdem em média $65 \%$ do volume de vendas em termos de embalagens para os genéricos, segundo dados de um estudo.

E aqui também trazemos a importante contribuição de Alberto Castro, trabalho intitulado "Mercado Farmacêutico Português no Séc. XXI - Marcas Vs. Genéricos", desenvolvido pelo investigador Alberto Castro no IPAM - The Marketing School, no Porto, no âmbito da tese de mestrado, mostra, porém, que há diferenças consoante as áreas terapêuticas. E, mesmo dentro da mesma área, há mudanças no comportamento de medicamento para medicamento, existindo alguns que podem ultrapassar os $80 \%$ de perdas e outros que conseguiram excepcionalmente continuar a crescer.

Alberto Castro analisou de 2003 a 2012 a evolução do volume de vendas de todos os medicamentos de marca para o qual passou a existir um genérico e selecionou depois cinco classes terapêuticas em termos de peso, onde analisou algumas tendências isoladas. Construiu,

\footnotetext{
${ }^{17}$ BROTAS, Carmen Lúcia Costa. Células-Tronco: Uma avaliação das (im)possibilidades de patenteamento. In: Congresso Nacional do CONPEDI, XVIII, 2009. São Paulo. Anais pág. 1211-1212. Acesso em: 03 de Dezembro de 2012. Pp. 1201-1219.
} 
ainda, um modelo preditivo para antecipar o comportamento de marcas que venham a perder a patente e a concorrer com genéricos. "Apesar de termos genéricos desde 2000, analisei os dados desde 2003, por ser a partir daí que começam a ter expressão, que aliás vindo a aumentar devido a políticas sucessivas dos diversos governos”, explica ao Público.

O investigador salienta que se concentrou no volume de vendas em unidades e não no valor, justificando que "o preço flutua muito e é uma variável de marketing, enquanto o volume não". A análise permitiu perceber que foi, sobretudo, a partir de 2007 que houve o grande revés, com os medicamentos de marca a baixarem dos 200 milhões de embalagens vendidas e os genéricos a ultrapassarem os 50 milhões. O crescimento dos genéricos trouxe também mudanças na liderança das farmacêuticas, com algumas empresas recentemente criadas e dedicadas às marcas brancas a tornarem-se líderes de mercado.

Os últimos dados da Autoridade Nacional do Medicamento (Infarmed) indicam que em 2013, ainda sem dados relativos a Dezembro, a quota de medicamentos genéricos nas farmácias atingiu, em termos de volume, os $27,9 \%$. A quota cresceu 6,3 pontos percentuais nos últimos três anos. No que diz respeito ao valor, o preço médio caiu de 20,38 euros em 2007 para 6,88 em 2013 - o que representa uma queda de mais de $66 \%$. As principais conclusões do trabalho mostram que os fármacos destinados ao aparelho cardiovascular são os mais afectados pela entrada dos genéricos, com perdas médias de $86 \%$ logo no primeiro ano, seguidos dos medicamentos para o sistema nervoso (40\%), para o aparelho respiratório (34\%), músculoesquelético (30\%) e digestivo e metabolismo (28\%). "Não esperava um número tão elevado nos 12 primeiros meses. Talvez no máximo $40 \%$, até por à medida que os anos vão passando o impacto ser cada vez maior", admite o autor.

Questionado sobre as consequências desta mudança ao fim de dez a 15 anos de patente, Alberto Castro considera que o grande problema é conseguir uma conjugação razoável. "É preciso um grande equilíbrio para ser possível continuarmos a ter tecnologia a preços acessíveis mas sem comprometer a investigação terapêutica. A área da antibioterapia é uma das que tem tido menos desenvolvimento, precisamente por o investimento não compensar. E esse é um dos principais motivos em termos de saúde pública para precisarmos de ter uma utilização racional dos antibióticos de que dispomos para as bactérias não ganharem resistências", sublinha. O investigador alerta que "com esta percentagem há o grande risco de a balança ficar mais do lado dos genéricos e de as farmacêuticas que não conseguirem renovar o seu portfólio irem desaparecendo, em especial em Portugal onde o mercado é muito pequeno e pouco apetecível e onde vão demorar mais a chegar os inovadores". 
Em relação às diferenças, Alberto Castro defende que "a área cardiovascular tem muito mais doentes a consumir medicamentos por serem normalmente patologias crónicas que implicam que a medicação seja feita de forma prolongada. Por isso, as pessoas tornam-se mais sensíveis ao preço do que quando têm, por exemplo, de tomar pontualmente um antibiótico ou um anti-inflamatório e em que não se compara tanto o valor e não se tem tanta referência". Mas mesmo dentro das patologias crónicas, o investigador encontrou excepções. "Dentro do sistema digestivo e metabolismo, na área da diabetes, os genéricos demoraram mais a penetrar, porque a comparticipação chegou a ser quase total e as pessoas não tinham qualquer incentivo para mudar, enquanto nas doenças gástricas a marca quase se eclipsou", exemplifica, acrescentando que outros "líderes" conseguiram-se manter à frente, aumentando até as vendas. "Há marcas que pela sua notoriedade até têm aumentado as vendas, como o Ben-u-ron ou a Aspirina [dois analgésicos] em que as pessoas continuam a não pedir pela substância”, afirma. Dentro da substituição de um medicamento de marca por um genérico, adianta que essa tendência é mais comum nos idosos "e muito mais conversadora" na área pediátrica.

\section{Conclusão}

Diante do exposto, podemos concluir que as patentes de invenções ao longo do tempo desenvolveram um importante papel de propagação da tecnologia e sua posterior evolução, trazendo benefícios a todos os povos, dos diferentes lugares do mundo, que direta ou indiretamente se beneficiaram e continuam se beneficiando com o avanço tecnológico.

Percebemos também que houve uma evolução da concessão de privilégios reais para a concessão legal das patentes, isto é, previstas num diploma legal.

Constatamos também que as patentes de invenções, quando ainda estão sob privilégio temporário, sua aquisição normalmente é por preços significativos, mas quando caem em domínio público, os preços caem vertiginosamente, pois considera-se que o inventor (ou o detentor da patente) teve tempo suficiente para se ressarcir dos investimentos feitos e até ter lucrado, para que venha fazer novas invenções que a todos beneficiam.

Que o instituto da proteção e do privilégio temporário conferido ao inventor é importante, pois só assim ele sente-se seguro para revelar sua (ou suas descobertas), pois o Estado lhe garantirá um privilégio temporário para explorar com exclusividade sua invenção.

\section{Referências bibliográficas}


BROTAS, Carmen Lúcia Costa. Células-Tronco: Uma avaliação das (im)possibilidades de patenteamento. In: Congresso Nacional do CONPEDI, XVIII, 2009. São Paulo. Anais

COELHO, Fábio Ulhoa. Curso de direito comercial: direito de empresa. $14^{\circ}$ ed. São Paulo: Saraiva, 2010. Vol.1

DEL NERO, Patrícia Aurélia. Propriedade Intelectual: a tutela jurídica da biotecnologia. SP, RT, 1998

FARIA, Carmen Rachel Scavazzini Marcondes. Patentes biológicas. 2001.

FERNANDES, Marcia Santana. Uma abordagem jurídica e bioética sobre as patentes envolvendo células-tronco humanas. Rio de Janeiro: Forense, 2009.

GANDELMAN, Henrique. De Gutenberg à Internet: direitos autorais na era digital. Rio de Janeiro, Editora Record, 1997

MANSO, Eduardo J. Vieira. O que é Direito Autoral. $2^{\text {a }}$ edição, São Paulo, Editora Brasiliense, 1992

REQUIÃO, Rubens. Curso de Direito Comercial. 27ª ed., 2007, vol. 1

SATO, Priscila Kei. O Instituto Nacional da Propriedade Intelectual nas Ações de Nulidade e de Adjudicação: parte ou assistente? In: DIDIER Jr., Fredie; WAMBIER, Teresa Arruda Alvim (Coords.). Aspectos Polêmicos e Atuais sobre os Terceiros no Processo Civil e Assuntos Afins. SP, RT, 2004

SCHIMIDT, Lélio Denicoli. “O INPI nas Ações de Nulidade de Marcas ou Patentes: assistente litisconsorte ou fiscal da lei? In Revista da ABPI, São Paulo, n. 26, p. 29-41, jan./fev. 1997, http://supreme.justia.com/us/437/584/case.html. Acessado em 10/12/2012.

VARELLA, Marcelo Dias. Propriedade Intelectual de setores emergentes: biotecnologia fármacos e informática - de acordo com a Lei n. 9.279/96. SP, Atlas, 1996. 


\title{
NANOTECNOLOGIA, ASPECTOS JURIDICOS ECONOMICOS DA CIENCIA DO FUTURO
}

\author{
Claudino Gomes
}

Uniceub e UNIRV - Universidade de Rio Verde - GO

Murilo Couto Lacerda

Uniceub e UNIRV - Universidade de Rio Verde - GO

\begin{abstract}
Resumo
O tema proposto para pesquisa encontra-se em constante avanço teórico-prático jurídico, portanto a proposta é observar a transdisciplinaridade e interdisciplinaridade das operações envolvendo a nanotecnologia e a sociedade em meio às imbricações da economia frente o avanço tecnológico, assim como o progresso tecnológico/ consumo, consumo/ meio ambiente, nanotecnologia e direito. Para a ciência, a nanotecnologia surge como uma medida padrão, enquanto a mesma surge como mecanismo de poder na comunicação econômica. Desta forma, como será realizada a gestão de risco, sua regulamentação e acoplamento estrutural entre os sistemas envolvidos. O recorte acompanhará a nanotecnologia empresarial, e a pesquisa será bibliográfica.
\end{abstract}

Palavras-chave: Nanotecnologia, Direito, Economia, Tecnologia, Avanços.

\section{Abstract/Resumen/Résumé}

The proposed is in constant theoretical-practical and legal progress, so the proposal is to observe the transdisciplinarity and interdisciplinarity of the operations involving nanotechnology and society amid the imbrications of the economy in front of the technological advance, as well as the technological / consumption, consumption / environment, nanotechnology and law. For science, nanotechnology emerges as a standard measure, while nanotechnology emerges as a mechanism of power in economic communication. In this way, how will be carried out the risk management, its regulation and structural coupling between the systems involved. The cut will accompany the business nanotechnology, and the research will be bibliographical.

Keywords/Palabras-claves/Mots-clés: Nanotechnology, Right, Economy, Technology, Advances. 


\section{Introdução}

A nanotecnologia ${ }^{1}$ é fruto do desenvolvimento da sociedade da informação, onde a globalização econômica e informacional do último quarto do século XX são os agentes condutores da evolução e revolução científica e tecnológica que estão perceptíveis por nós nos dias de hoje.

A nanotecnologia é vista como panacéia apta a resolver todos os problemas da humanidade. A aplicação da nanotecnologia em materiais vendidos no Brasil e no mundo, em larga escala, já é fato, muito embora, não haja mensuração dos riscos, podendo influir de forma depredatória no ecossistema como um todo do qual o Homem é parte.

Importa, portanto, inserir na agenda nacional o debate a respeito do tema envolvendo todas as partes interessadas: governo, empresas, universidades, população e sociedade civil organizada, no afã de promover o debate horizontal para adoção de boas práticas corporativas, uniformização da linguagem, destinação orçamentária em pesquisa preventiva e de mensuração de riscos com criação de banco de dados público e transparente.

Outrossim, promover a educação da população sobre benefícios e malefícios, adotar boas práticas no desenvolvimento científico laboratorial, tudo como forma de garantir o desenvolvimento econômico e social sustentável no Brasil e para alcançar os países desenvolvidos nos debates e decisões sobre o assunto, já que a pauta se desdobra em discussões de como a nanotecnologia irá dar novos rumos a economia.

Desta forma, surge a seguinte indagação, quais seriam as formas de regulamentação para avanço da nanotecnologia, e quais as prevenções possíveis de se realizar, tanto no âmbito jurídico quanto econômico.

O método utilizado para responder tal proposição parte do hipotético-dedutivo em conformidade com a argumentação apresentada nesta pesquisa, utilizando de material bibliográfico para corroborar a conjectura trabalhada.

\footnotetext{
1 A nanotecnologia é a manipulação da matéria numa escala atômica e molecular. Geralmente lida com estruturas com medidas entre 1 a 100 nanômetros em ao menos uma dimensão, e inclú o desenvolvimento de materiais ou componentes e está associada a diversas áreas (como a medicina, eletrônica, ciência da computação, física, química, biologia e engenharia dos materiais) de pesquisa e produção na escala nano (escala atômica). O princípio básico da nanotecnologia é a construção de estruturas e novos materiais a partir dos átomos. É uma área promissora, mas que dá apenas seus primeiros passos, mostrando, contudo, resultados surpreendentes (na produção de semicondutores, Nanocompósitos, Biomateriais, Chips, entre outros). Criada no Japão, a nanotecnologia busca inovar invenções, aprimorando-as e proporcionando uma melhor vida ao Homem.
} 


\section{Nanotecnologia a Economia do Futuro}

No sentido de entendermos melhor a nanotecnologia e considerando o corpo humano como um exemplo dotado de um conjunto de elementos químicos, nos quais separados individualmente não haveria nenhum valor agregado que pudesse justificar a complexidade da criação, assim, propomos uma análise exemplificativa do conjunto de substancias e sua formulação na composição do próprio ser humano.

Nanotecnologicamente seríamos capazes de colecionar uma porção significativa de gases e encher umas botijas de hidrogênio, oxigênio e azoto. Poderíamos também empilhar quantidades de carbono e cálcio. E talvez, inesperadamente, iríamos encontrar pequenas frações de praticamente tudo, como por exemplo ferro, ouro, prata, arsênico, urânio e cobre. Contudo, se fosse à bolsa de valores de Nova Iorque vender estes ingredientes, chamados átomos, não conseguiria mais do que 100 euros. É este o nosso valor? De fato não, dado que é a quantidade precisa destes ingredientes e a forma como se ligam que permite ao ser humano comer, falar, pensar e até reproduzir-se.

Neste contexto, podemos colocar a questão: e se nós conseguíssemos construir objetos seguindo este processo da natureza, controlando a adição de cada átomo? Em 1959, o físico Richard Feynman² já dizia que "o ideal numa cirurgia seria ter o cirurgião dentro do meu corpo, a diagnosticar e a reparar o problema".

De fato, a alusão de Feynman relacionava-se com a possibilidade de ter máquinas miniaturizadas (nano-máquinas) capazes de passear pelos nossos vasos sanguíneos e fazer o papel de cirurgião. O termo "nanotecnologia" foi inicialmente usado em 1974 por Norio Taniguchi $^{3}$ mas a sua origem advém da palavra "nano", que significa em grego "anão" e representa um bilionésimo da unidade. A nanotecnologia é, portanto, a tecnologia relacionada com estas ínfimas dimensões, entre 1000 e 100 mil vezes mais pequenas que o diâmetro de um cabelo humano.

\footnotetext{
2 Richard Philips Feynman (Nova Iorque, 11 de maio de 1918 - Los Angeles, 15 de fevereiro de 1988) foi um físiconorte-americano do século XX, um dos pioneiros da eletrodinâmica quântica, e Nobel de Física de 1965. Feynman foi pioneiro na área de computação quântica, introduzindo o conceito de nanotecnologia, no encontro anual da Sociedade Americana de Física, em 29 de dezembro de 1959, em sua palestra sobre o controle e manipulação da matéria em escala atômica. Defendeu a hipótese de que não existe qualquer obstáculo teórico à construção de pequenos dispositivos compostos por elementos muito pequenos, no limite atômico, nem mesmo o princípio da incerteza.

3 Foi professor da Tokyo Science University .Ele cunhou o termo nanotecnologia, em 1974 [ 1 ] para descrever os processos de semicondutores, como a deposição de película fina e moagem feixe de íons exibindo controle característica da ordem de um nanômetro: "Nanotecnologia" consiste principalmente de processamento de separação, consolidação, e deformação dos materiais por um átomo ou uma molécula.
} 
Embora a nanotecnologia tenha nascido há pouco tempo, prevê-se que o seu impacto seja semelhante à descoberta da eletricidade. De fato, a nanotecnologia é o elo que faz convergir o mundo digital, físico e biológico, definido como a quarta revolução industrial. Pela primeira vez estes três mundos conseguem comunicar entre si, porque os seus intervenientes (células, transístores, metais, cerâmicos) transferem informação à escala nano.

A partir desta quarta revolução industrial, surgirão implantes celulares, nanomáquinas capazes de entrar no nosso corpo e navegar para identificar e eliminar vírus, bactérias ou células cancerígenas, impressão a 3D de órgãos humanos, materiais ultra-resistentes e auto-reparáveis, sensores subcutâneos capazes de identificar qualquer alteração no nosso corpo, novos materiais capazes de armazenar, transportar e fornecer energia, e muitas outras invenções impossíveis de imaginar.

Esta transformação produzirá alterações significativas na forma como produzimos, consumimos, comunicamos e vivemos. Tal como aconteceu com as revoluções tecnológicas passadas, a quarta revolução industrial irá colocar desafios imprevisíveis à sociedade atual. Contudo, as mudanças serão maiores, mais rápidas e mais abrangentes. O que se espera então do impacto da nanotecnologia na sociedade? As primeiras estimativas apontam para desenvolvimentos drásticos em termos de recursos humanos, inovações e valor econômico.

No que diz respeito às pessoas, uma extrapolação feita pela iniciativa nacional de nanotecnologia norte-americana indica que em 2020 cerca de seis milhões de postos de trabalho sejam relacionados com nanotecnologia. Este capital humano, mesmo aquele associado às zonas de produção das empresas, necessita de possuir conhecimento tecnológico, manter-se em formação contínua e demonstrar flexibilidade nas suas capacidades técnicas para se adaptar às novas exigências do mercado. Dada a velocidade estonteante com que a tecnologia avança, assim como as flutuações bruscas na economia, estes recursos humanos vão ser exigidos a reinventarem-se rapidamente.

Relativamente às inovações, de acordo com o relatório da StatNano ${ }^{4}$, temos assistido desde 2011 a um número médio de publicações de cerca de 120 mil por ano, enquanto o número médio de patentes publicadas tem atingido as 11 mil por ano.

Quanto ao mercado relacionado com a nanotecnologia, as vendas relacionadas com esta área cresceram, entre 2012 e 2014, de 167 mil milhões dólares para 453 mil milhões de

\footnotetext{
4 A Statnano fornece o ranking global e regional dos principais indicadores de nanociência, tecnologia e indústria (NSTI). Além disso, é composto por diferentes bases de dados de nanotecnologia, como produtos, empresas, padrões, eventos, organizações e planos estratégicos nacionais.
} 
dólares, segundo um relatório publicado pela Lux Research ${ }^{5}$. Em particular, o mercado atual centra-se em materiais compósitos para a indústria automóvel e desporto de alta competição, revestimentos antibacterianos, filmes finos para dispositivos eletrônicos e fotovoltaicos, assim como nanopartículas para cosméticos, tintas, adesivos e medicamentos. No futuro, a ideia da nanotecnologia é fazer parte da solução dos grandes desafios que nos enfrentam, tais como as questões da energia, saúde, educação, o ambiente e o desenvolvimento global.

Desta forma, a nanotecnologia requer a participação atenta do governo, indústria e universidades. Em primeiro lugar, o governo precisará criar um cluster ligado à nanotecnologia, capaz de promover a troca livre de ideias e conhecimento entre cientistas, investigadores, empreendedores, empresas, clientes e fornecedores, criando sinergias entre estes atores.

O Instituto Ibérico Internacional de Nanotecnologia (INL) em Braga poderá ser o elo de ligação entre os vários setores. Em relação ao setor empresarial, as grandes e médias empresas deverão incluir na sua estrutura departamentos e/ou gabinetes que possam explorar esta vertente tecnológica.

Para isso é essencial contratar e reter recursos humanos especializados capazes de desenvolver ideias inovadoras. Em muitos casos, o talento em bruto já existe dentro da empresa, a questão consiste em entender como está organizado, reconhecer-lhe valor e mobilizá-lo para inovar. Este processo passa também por uma aproximação efetiva ao setor académico.

Assim, a ideia de separar o trabalho teórico do trabalho prático é hoje em dia um conceito verdadeiramente obsoleto. Pelo contrário, nesta nova economia o espectro do conhecimento é contínuo, onde as empresas necessitam de conceitos teóricos para desenvolver os seus produtos, enquanto as universidades precisam de considerar a aplicação das suas teorias.

Além disso, as universidades terão que refletir sobre os correntes currículos acadêmicos, os quais requerem uma constante atualização, de forma a criar futuras gerações de profissionais com as competências necessárias para integrar o mercado de trabalho. Se esta preparação académica for deficiente, o nível de desemprego aumentará, pelo que é provável

5 A Lux Research é uma provedora líder de soluções de inteligência de mercado, ajudando empresas globais a identificar as oportunidades de inovação tecnológica que impulsionam o crescimento. É uma empresa independente de pesquisa e consultoria, fornecendo consultoria estratégica e inteligência contínua sobre tecnologias emergentes.

6 O Laboratório Ibérico Internacional de Nanotecnologia, INL é uma organização intergovernamental criada para fomentar a investigação interdisciplinar em Nanotecnologia e Nanociência. Com o objetivo de se tornar uma parte vital da ciência europeia, o INL oferece um ambiente de investigação em alta tecnologia, sobre desafios em nanomedicina, nanotecnologia aplicada à nanoeletrônica ambiental e de controlo alimentar e nanomáquinas e manipulação molecular em nanoescala. 
que cause rupturas sociais e económicas, elevando assim a diferença relativa às economias mais industrializadas e desenvolvidas.

Conforme aconteceu com as passadas revoluções industriais, a nanotecnologia vai ser certamente um divisor de águas na História, onde praticamente todos os aspectos da vida quotidiana irão ser impactados pelo desenvolvimento desta tecnologia. Contudo, o futuro, esse será difícil de imaginar. Afinal de contas, Thomas Watson7, presidente da IBM, dizia em 1943: “Eu acho que o mundo não terá mais de cinco computadores." Hoje existem dois mil milhões.

\section{Comunicação Tecnológica, Economia e Sistema do Direito}

A humanidade está na iminência de uma nova revolução industrial que será guiada pela nanociência, tão grandiosa que seus efeitos serão mais incisivos do que as tecnologias de informação e comunicação que originaram a Nova Economia no final do século passado. Essa revolução nanotecnológica supõe uma mudança radical nas condições materiais do atual modelo produtivo, mudanças essas que não serão isentas de problemas e questionamentos.

Dada a importância do tema, é necessária uma analise critica, objetiva, holística e prudente diante de cada sistema que envolve essa nova tecnologia, pois existe uma tendência de otimismo tecnológico cético por parte da comunidade cientifica e do mundo industrializado, que acaba por marginalizar os efeitos sociais e ambientais da tecnologia (GARI, 2010) ${ }^{8}$.

Partindo dessas premissas, a Organização Regional Interamericana de Trabalhadores, que faz parte da Confederação Sindical Internacional, com base na Declaração denominada "Princípios para a Fiscalização de nanotecnologias e nanomateriais" (2007) ${ }^{9}$, destacou que ja e consenso entre a maioria dos pesquisados da nanotecnologia, a enorme competição que existe entre governos, universidades e empresas na comercialização das nanotecnologias e dos nanomateriais. Mas, como assevera tal Declaração, existem muitas evidencias relacionadas aos perigos dessa tecnologia, que dizem respeito a saúde, segurança e ao meio ambiente, além dos "profundos desafios sociais, econômicos e éticos representados por esta nova revolução dos materiais".

7 Foi um empresário estadunidense. Foi presidente da Computing-Tabulating-Recording Company, empresa que deu origem à IBM (International Business Machine), uma das poucas empresas da área de Tecnologia da Informação (TI) com uma história contínua que remonta ao século XIX.

8 GARI, Manoel. Nano-amizades perigosas. 2010. Disponivel em: $<$ http://www.esquerda.net/virus/index. php?option=com_content\&task=view\&id=146\&Itemid=26>. Acesso em: 15 março 2018.

9 IIEP. Intercambio, informações, estudos e pesquisas. Princípios para a físcalização de nanotecnologias e nanomateriais.

Disponível em:<http://www.iiep.org.br/nano/fundacentro/principles.pdf>. Acesso em: 12 março. 2018. 
Outro apontamento, que ainda chama a atenção, na introdução dessa Declaração são as questões relacionadas as inúmeras situações que este órgão de representação de toda uma classe, faz em relação a nanotecnologia:

\begin{abstract}
Ambientes fabris e laboratoriais operam sem a apropriada orientação de segurança ou medidas de proteção. Os consumidores são constantemente expostos a nano ingredientes não rotulados nos produtos, sem serem informados de seus potenciais riscos. Nanomateriais são descartados e liberados no meio ambiente a despeito de seus impactos desconhecidos e dos meios inadequados de detecção, acompanhamento e remoção desses novos materiais. Os governos e empresas que desenvolvem nanotecnologias fornecem poucas oportunidades reais para a participação publica informada nas discussões e decisões sobre como, ou mesmo se devemos, prosseguir com a "nano" do mundo. (Princípios para a Fiscalização de nanotecnologias e nanomateriais, 2007). ${ }^{10}$
\end{abstract}

Frente a essas situações de risco, as quais a sociedade esta exposta, qual e o papel do Direito na sociedade? Ate que ponto o vigente sistema legal tem "capacidade" de resolver essas questões, uma vez que, como o próprio Kelsen $(2003)^{11}$ expressou em sua famosa formula, "tudo o que não esta proibido é permitido"?

Para Moreira (2006) “o Direito ainda não se estruturou adequadamente para dar respostas aos desafios propostos pelas novas tecnologias [...] É necessário ampliar a reflexão jurídica para além da visão exclusivamente patrimonialista [...]"12.

Essa situação e caracterizada: por forte interação ciência-indústria; pelo enaltecimento do conhecimento cientifico, entre outros. Assim, segundo Moreira, essa proximidade entre ciência e indústria foi marcada por uma ruptura epistemológica, pois sua consequência imediata e a pressão por resultados, a valorização de especialidade, separando ainda mais o conhecimento da sociedade. $(2006)^{13}$.

A principal característica da interação ciência/indústria, esta no fato de a ciência perder seu status de neutralidade, pois passa a agir de acordo com o mercado, e este por sua

\footnotetext{
${ }^{10}$ IIEP. Intercambio, informações, estudos e pesquisas. Princípios para a fiscalização de nanotecnologias e nanomateriais.

Disponível em:<http://www.iiep.org.br/nano/fundacentro/principles.pdf $>$. Acesso em: 12 março. 2018.

${ }^{11}$ KELSEN, Hans. Teoria pura do direito. 6. ed. Trad. de Joao Batista Machado. São Paulo: M. Fontes, 2003.

${ }^{12}$ MOREIRA, Eliane Cristina P. Nanotecnologia e regulação: as inter-relações entre o direito e as ciências. In: MARTINS, Paulo Roberto (Org.). Nanotecnologia, sociedade e meio ambiente. São Paulo: Xama, 2006. p. 309313.

${ }^{13}$ MOREIRA, Eliane Cristina P. Nanotecnologia e regulação: as inter-relações entre o direito e as ciências. In: MARTINS, Paulo Roberto (Org.). Nanotecnologia, sociedade e meio ambiente. São Paulo: Xama, 2006. p. 309313
} 
vez, não tem limite na busca de atender a ansiedade social por novos produtos e novas tecnologias (MOREIRA, 2006) ${ }^{14}$.

O reconhecimento dessa situação passa a ter extrema importância, segundo Moreira $(2006)^{15}$, pois “alguns importantes elementos passam a ter menor importância nas discussões sobre a regulamentação de tecnologias como a nanotecnologia", ou seja, como o mercado passa a definir as áreas prioritárias de interesse, o sistema econômico passa a ser privilegiado em detrimentos de todos os demais sistemas sociais, incluindo-se o Direito. De acordo com a Declaração contendo os Princípios para a fiscalização de nanotecnologias e nano materiais (2007), o segundo principio analisado se refere a "Regulação Nano Especifica Compulsória", no qual resta claramente posicionado que serão necessárias mudanças estruturais regulatórias no sistema legal. Nesse aspecto afirma:

\begin{abstract}
Mesmo onde a autoridade legal e exercida, e bastante provável que profundas mudanças regulatórias sejam necessárias a fim de abordar adequada e efetivamente as diferentes propriedades dos nanomateriais e os novos desafios que estes representam. As leis atuais estão ainda menos equipadas para fiscalizar produtos e processos tais como nanosistemas e nanoestruturas ora em desenvolvimento. (Princípios para a fiscalização de nanotecnologias e nanomateriais, 2007). ${ }^{16}$
\end{abstract}

Mas, as afirmações contidas nessa Declaração vão além, pois, segundo esse documento, "as agencias governamentais ate o momento vem falhando no uso de sua atual autoridade regulatória", uma vez que todo o arcabouço jurídico envolvendo regulação deve ser ajustado para aplicação imediata, mesmo que temporária, ate que "mecanismos de fiscalização nano específicos possam ser formulados e implantados". (Princípios para a Fiscalização de nanotecnologias e nanomateriais, 2007) ${ }^{17}$.

\footnotetext{
${ }^{14}$ MOREIRA, Eliane Cristina P. Nanotecnologia e regulação: as inter-relações entre o direito e as ciências. In: MARTINS, Paulo Roberto (Org.). Nanotecnologia, sociedade e meio ambiente. São Paulo: Xama, 2006. p. 309313

${ }^{15}$ MOREIRA, Eliane Cristina P. Nanotecnologia e regulação: as inter-relações entre o direito e as ciências. In: MARTINS, Paulo Roberto (Org.). Nanotecnologia, sociedade e meio ambiente. São Paulo: Xama, 2006. p. 309313

${ }^{16}$ IIEP. Intercambio, informações, estudos e pesquisas. Princípios para a fiscalização de nanotecnologias e nanomateriais.

Disponível em:<http://www.iiep.org.br/nano/fundacentro/principles.pdf $>$. Acesso em: 12 março. 2018

17 IIEP. Intercambio, informações, estudos e pesquisas. Princípios para a fiscalização de nanotecnologias e nanomateriais.

Disponível em:<http://www.iiep.org.br/nano/fundacentro/principles.pdf>. Acesso em: 12 março. 2018
} 
De acordo com Berger Filho $(2014)^{18}$, na maior parte dos ordenamentos jurídicos nacionais, e mesmo no Direito Internacional, ainda são incipientes as iniciativas de proteção jurídica contra os riscos da nanotecnologia.

Como afirma Moreira (2006), "tudo o que o Direito pode dar e uma pequena contribuição ao delicado equilíbrio entre o desejo por novas tecnologias e a preocupação com os riscos que isso comporta".

Um importante questionamento que precede o Direito positivado, em sua forma propriamente dita (leis, decretos, normas, etc.), é saber se o País deve ser conduzido a uma regulação ou a uma regulamentação? (MOREIRA, 2005) ${ }^{19}$. Pois, como a autora afirma, ao assumir a regulamentação como marco basilar, pode-se atingir diversos fins, desde a potencialização da tecnologia ou um sistema de proteção do cidadão. Ao se optar por uma regulação, poderia ser adotado o modelo norte-americano, em que as Agencias de Regulação, segundo Rochael $(2004)^{20}$, pregam a total ausência de influencias politicas nas decisões dessas agencias, além do que "o direito administrativo americano transfere para as agencias o controle do mercado econômico".

Com o objetivo de buscar respostas e paradoxalmente formular novos questionamentos a respeito de um marco de sustentação da nanotecnologia na sociedade, Berger Filho apresentou diferentes perspectivas para a gestão dos riscos que dizem respeito a essa nova tecnologia, observando critérios legais e normas de conduta não jurídicas:

1) Regulamentação legal:

a) A utilização da legislação estatal existente e de tratados internacionais internalizados (ratificados).

i) É necessário inserir novos artigos nos textos legais já existentes, tratando de forma diferenciada a nanotecnologia ou as normas existentes são suficientes para gerir os riscos das nanotecnologias?

ii) Seria necessário a proposição da inserção de preceitos relativos a "nanosseguranca" em tratados internacionais já existentes - sejam eles cogentes (hard law)21 ou não cogentes (soft law)22 - ou os tratados ratificados pelo Brasil são suficientes?

18 Berger Filho A. G. - Nanotecnologia e o princípio da precaução na sociedade de risco, 2014, texto disponível em: http://www.ambito-juridico.com.br/site/index.php?n_link=revista_artigos_leitura\&artigo_id=7084; acesso em 23 março 2018.

19 MOREIRA, Eliane Cristina P. Nanotecnologia e regulação: as inter-relações entre o direito e as ciências. In: MARTINS, Paulo Roberto (Org.). Nanotecnologia, sociedade e meio ambiente. São Paulo: Xama, 2006. p. 309313

20 ROCHAEL, Carlos Henrique Reis. As agências de regulação brasileiras. 2004. Disponível em: $<\mathrm{http} / /$ jus2.uol.com.br/doutrina/texto.asp?id=6822>. Acesso em: 22 março. 2018.

21 soft law ou droit mou do direito internacional e traduz, de forma genérica, regras cujo valor normativo é limitado e que não são juridicamente obrigatórias

22 refere-se a instrumentos legais e leis vinculantes reais. Em contraste com o soft law, a lei dura dá aos Estados e aos atores internacionais responsabilidades efetivas vinculantes, bem como direitos. $\mathrm{O}$ termo é comum no direito internacional, onde não há órgãos soberanos. Hard law significa leis obrigatórias. 
b) A criação de um marco legal nacional para a "nanosseguranca":

i) Além do marco regulatório geral o ordenamento necessitaria de norma especial para cada especificidade apresentada pelas diferentes formas de nanotecnologia?

ii) As especificidades sobre diferentes pesquisas, produtos e processos e, portanto, diferentes riscos seriam positivadas em normas jurídicas especificas e cogentes ou as especificidades ficariam a cargo da auto regulação das próprias empresas e do mercado, ou da normatização e da certificação?

iii) Seria necessária a criação de uma estrutura própria com uma instituição nos mesmos moldes do estabelecido para a Biossegurança, uma "Comissão Técnica Nacional de Nanoseguranca" ou uma agencia reguladora especifica?

c) A elaboração de um tratado internacional especifico para a nanotecnologia:

i) $\mathrm{O}$ tratado deve ser uma norma obrigatória (hard law), como a proposta feita pelo Grupo ETC, a Convenção Internacional para Avaliação de Novas Tecnologias (ICENT)?

ii) Teria melhor resultado a elaboração de um tratado, tratados internacionais, recomendações de organizações internacionais, protocolos facultativos não obrigatórios, não cogentes (soft law) com Códigos de Conduta, Diretrizes de Boas Praticas para que ocorra um avanço gradual na regulamentação internacional de novas tecnologias?

2) Auto Regulação:

a) Auto regulação e auto certificação por empresas através de programas internos de gestão de riscos, apoiados ou não por convênios com a sociedade civil organizada (organizações não-governamentais), universidades ou instituições estatais (órgãos de proteção ambiental ambientais, órgão de saúde...) que servem para dar maior confiabilidade. Ex: Programa Marco de Gestão de Riscos da Du Pont (Nano Risk Framework).

b) A criação de Códigos de Conduta ou Guias de Boas Praticas, estabelecidos por cientistas e instituições do setor, não obrigatórios para a Pesquisa Responsável em Nanotecnologia e Nanociência.

3) Criação de um sistema internacional de normas técnicas específicas para a nanotecnologia: Normas não jurídicas, mas passiveis de ser impostas pelo sistema legal através de exigências técnicas especificas. (BERGER FILHO, 2014). ${ }^{23}$

A partir desses questionamentos e ponderações, será realizada uma analise que engloba três pontos principais abordados: regulamentação, autorregulacão e criação de um sistema internacional de normas técnicas especificas para a nanotecnologia.

\subsection{Regulamentação da nanotecnologia}

A regulamentação e a forma de controle social, através de meios legais (leis, decretos, resoluções, etc.) pelos quais poderiam ser prevenidos danos a nanotecnologia e fiscalizar sua comercialização e produção, além de realizar uma gestão dos riscos que envolvem essa tecnologia. Bem como ser utilizada como acoplamento estrutural entre a tecnologia e a sociedade.

\footnotetext{
${ }^{23}$ Berger Filho A. G. - Nanotecnologia e o princípio da precaução na sociedade de risco, 2014, texto disponível em: http://www.ambito-juridico.com.br/site/index.php?n_link=revista_artigos_leitura\&artigo_id=7084; acesso em 23 março 2018.
} 
Para dimensionar a questão envolvendo os nanomateriais Paschoalino, Marcone e Jardim (2010) afirmam que "a regulamentação dos nanomateriais é imprescindível, pois ate 2008, segundo PEN (Project on Emerging Nanotechnologies) ${ }^{24}$, o numero de produtos com algum componente nanometrico chegou a cerca de 800”, sendo que o setor de semicondutores e metade do setor farmacêutico estarão dependentes desses novos materiais. Tanto nos Estado Unidos, através do Environmental Protection Agency (EPA) ${ }^{25}$, como na Uniao Europeia, atraves da Registration, Evoluation, Authorisation \& Restriction of Chemicals Competent Authorities (REACH CA) ${ }^{26}$, é visível a falta de legislação que regulamente o uso de produtos nanotecnologicos.

De acordo com Berger Filho (2014), no Brasil, “o desenvolvimento de normas jurídicas relativas a nanotecnologia se da principalmente no que concerne a promoção de politicas de incentivo e cooperações tecnológicas" ${ }^{27}$, pois não se encontra proteção legal especifica, tanto envolvendo a sociedade como o meio ambiente, em relação aos potenciais riscos que poderão advir da nanotecnologia.

\subsubsection{Direito do consumidor e nanotecnologia}

A principal característica de uma sociedade do consumo, segundo Baumam (2008) ${ }^{28}$, reside na satisfação dos desejos humanos, que "nenhuma sociedade do passado pode alcançar, ou mesmo sonhar”. O grande problema da satisfação social, com base no consumo, reside na politica da obsolescência, seja ela planejada, seja perceptiva, o que forca incansavelmente a

\footnotetext{
${ }^{24}$ O Projeto sobre Nanotecnologias Emergentes foi estabelecido em 2005 como uma parceria entre o Centro Internacional de Pesquisadores Woodrow Wilson e o Pew Charitable Trusts . [1] O projeto tinha como objetivo abordar os aspectos sociais, políticos e de segurança pública da nanotecnologia . Pretendeu, em particular, procurar investigações e lacunas de políticas e oportunidades nos processos de conhecimento e de regulamentação e desenvolver estratégias para os fechar. O projeto trabalhou com vários governos e organizações dos EUA e de outros países.

${ }^{25}$ A Agência de Proteção Ambiental dos Estados Unidos (Environmental Protection Agency, EPA ou às vezes, USEPA em inglês) é uma agência federal do governo dos Estados Unidos da América, encarregada de proteger a saúde humana e o meio ambiente: ar, água e terra. A EPA começou a funcionar em 2 de dezembro de 1970, quando foi instituída pelo presidenteRichard Nixon. É chefiada por um administrador, indicado pelo presidente. A EPA não é um ministério de facto, mas o administrador geralmente possui status ministerial. Em 2007, a agência possuía 17000 funcionários em tempo integral.

${ }^{26} \mathrm{O}$ REACH é um regulamento da União Europeia relativo ao registo, avaliação, Autorização e restrição de produtos químicos (EC 1907/2006) visa melhorar a proteção da saúde humana e do meio ambiente através da melhor e mais precoce identificação das propriedades intrínsecas das substâncias químicas. Isto é feito pelos quatro processos do $\mathrm{REACH}$, nomeadamente o registo, avaliação, autorização e restrição de produtos químicos. $\mathrm{O}$ REACH também visa melhorar a inovação e a competitividade da indústria química da UE.

${ }^{27}$ Berger Filho A. G. - Nanotecnologia e o princípio da precaução na sociedade de risco, 2014, texto disponível em: http://www.ambito-juridico.com.br/site/index.php?n_link=revista_artigos_leitura\&artigo_id=7084; acesso em 23 março 2018.

${ }^{28}$ BAUMAN, Zygmunt. Vida para o consumo: a transformação das pessoas em mercadorias.Trad. de Carlos Alberto Medeiros. Rio de Janeiro: J. Zahar, 2008.
} 
matriz industrial a lançar novos produtos, e que acaba pela entrada no mercado, por força consumerista, de produtos que não estão devidamente qualificados, ou, ainda pior, não possuem a adequada gestão de risco.

Dessa forma, surgem questões como: De que maneira estabelecer um sistema de normas para garantir a segurança no consumo de produtos derivados da nanotecnologia? É necessário impor a indústria e ao comercio a identificação dos produtos da nanotecnologia? Como responsabilizar danos ao consumidor?

Essas preocupações também foram arguidas pela Organização Regional Interamericana de Trabalhadores e pela Confederação Sindical Internacional, com base no documento denominado "Princípios para a Fiscalização de Nanotecnologias e Nano materiais" (2007). No principio oitavo foi descrita a "Responsabilidade Civil do Fabricante":

\begin{abstract}
Os nanomateriais tomaram de assalto o mercado, rotulados de substancias milagrosas com qualidades notáveis que os tornam desejáveis em quase todos os setores da economia. Como o asbesto quando de sua introdução no mercado, os impactos sobre a saúde publica e o meio ambiente provocados pelos nanomateriais pouco foram estudados. Tanto mais que $\mathrm{o}$ asbesto, os nanomateriais possuem qualidades (formato, tamanho, reatividade química) que tem o potencial de torna-los particularmente de risco. Os nanomateriais são vendidos ao publico em geral em produtos de consumo sem qualquer aviso ou alerta quanto a seu perigo potencial. Além disso, como na indústria tabagista, as nano indústrias parecem contentes em comercializar seus produtos sem entender plenamente os riscos potenciais ou informar o publico sobre esses riscos. (Princípios para a Fiscalização de Nanotecnologias e Nanomateriais, 2007)..$^{29}$
\end{abstract}

Uma situação desse porte causa enorme mal-estar em qualquer cidadão consumidor, pois vem demonstrar que o lucro sobre o produto e uma vantagem tecnológica sobre a concorrência são fatores mais importantes do que o potencial risco em que os consumidores estão expostos.

A preocupação a esse respeito e tão grave que a Proposta de Resolução sobre os aspectos regulamentares dos nanomateriais $(2009)^{30}$, da União Europeia, concluiu pela inexistência de informações claras sobre a utilização de nanomateriais em produtos de consumo; contudo, verificou que o termo nano tem um efeito positivo no marketing.

A proposta da União Europeia ressalvou ainda que diferentes categorias de pessoas possam estar em risco, nas diversas fases de vida do produto: desde as fases de produção e

\footnotetext{
${ }^{29}$ IIEP. Intercambio, informações, estudos e pesquisas. Princípios para a físcalização de nanotecnologias e nanomateriais. Disponível em: $<\mathrm{http}: / / w w w . i i e p . o r g . b r / n a n o / f u n d a c e n t r o / p r i n c i p l e s . p d f>$. Acesso em: 12 março. 2018

${ }^{30} \mathrm{http}: / /$ www.europarl.europa.eu/sides/getDoc.do?pubRef=-//EP//TEXT+REPORT+A6-2009-

$0255+0+\mathrm{DOC}+\mathrm{XML}+\mathrm{V} 0 / / \mathrm{PT}$ - acesso em 24 de março de 2018.
} 
manuseamento, na embalagem, no transporte e na manutenção, durante a eliminação e demolição, e, ainda e principalmente, os usuários finais, os consumidores.

Assim, exortou a aplicação do principio "sem informação, não ha acesso ao mercado" em relação a todos os produtos que utilizam nanomateriais, com potenciais impactos de risco para a saúde e o ambiente. Em relação aos dispositivos legais que atualmente vigem no Brasil, que tem por objeto a proteção dos consumidores, destacam-se a referencia em nossa Carta Magna, no inciso XXXII, do art. $5^{\circ}$, em que o Estado promovera a defesa do consumidor, na forma da lei.

Essa proteção, contida na Lei $8.078 / 90$, com destaque para o art. $6^{\circ}$, prevê, como direitos básicos do consumidor: a proteção da vida, saúde e segurança contra riscos, a adequada informação sobre os diferentes produtos; além da efetiva prevenção e reparação dos danos, entre outros. No que se refere a rotulagem, existe o Decreto 4.680/03, que diz respeito a Rotulagem de Organismos Geneticamente Modificados no Brasil, que poderia ser utilizado, através da analogia, ate a formulação de uma norma especifica sobre nanotecnologia.

Importante frisar, que consta no Senado Federal o Projeto de lei 131, de 2010, que dispõe sobre a vigilância sanitária a que ficam sujeitos os medicamentos, as drogas, os insumos farmacêuticos e correlatos, cosméticos, saneantes e outros produtos, e da outras providencias, para determinar que rótulos, embalagens, etiquetas, bulas e materiais publicitários de produtos elaborados com recursos da nanotecnologia contenham informação sobre esse fato.

No oitavo principio do documento, "Princípios para a Fiscalização de Nanotecnologias e Nanomateriais" (2007) $)^{31}$, ha a afirmação de que todos os envolvidos na cadeia comercial de produtos com nanotecnologia (pesquisadores, fabricantes, varejistas) devem responsabilizar-se por eventuais problemas que seus produtos possam ocasionar. A partir disso concluiu-se que:

\footnotetext{
... enquanto ações judiciais contra produtos sejam a principal responsabilidade da indústria de nanomateriais, outras formas de responsabilização, tais como negligencia, responsabilidade derivada ,incomodo, fraude e falsidade ideológica, também são relevantes. Além disso, os regimes de fiscalização de nanomateriais devem incluir mecanismos financeiros, mantidos por fabricantes e distribuidores, que assegurem a disponibilidade de fundos para compensar e/ou remediar quaisquer potenciais prejuízos a saúde, ao trabalho e ao meio ambiente. (Princípios para a Fiscalização de Nanotecnologias e Nanomateriais, 2007). ${ }^{32}$
}

\footnotetext{
${ }^{31}$ IIEP. Intercambio, informações, estudos e pesquisas. Princípios para a fiscalização de nanotecnologias e nanomateriais.

Disponível em: $<$ http://www.iiep.org.br/nano/fundacentro/principles.pdf $>$. Acesso em: 12 março. 2018

32 IIEP. Intercambio, informações, estudos e pesquisas. Princípios para a fiscalização de nanotecnologias e nanomateriais. Disponível em: $<$ http://www.iiep.org.br/nano/fundacentro/principles.pdf $>$. Acesso em: 12 março. 2018
} 
Assim, não resta outra forma de efetivar o principio da precaução e, consequentemente, proteger o consumidor final, senão houver a responsabilização daqueles que deveriam realizar uma adequada gestão dos riscos, sejam eles dos setores de desenvolvimento da nanotecnologia, sejam do setor de comercialização, e que, por alguma razão, vierem a causar danos a saúde das pessoas ou ao meio ambiente.

\subsubsection{Direito sanitário, direito da alimentação e nanotecnologia}

A tecnologia que envolve a engenharia de alimentos, surge como "potencial de mudar drasticamente a maneira como os alimentos são produzidos, cultivados, processados, embalados, transportados e mesmo comidos". (2005) ${ }^{33}$.

Com a identificação desse enorme potencial, a Organização das Nações Unidas para a Agricultura e a Alimentação (FAO) e a Organização Mundial da Saúde (OMS) realizaram uma investigação para determinar as implicações da nanotecnologia na segurança alimentar.

Em meados de 2009, um grupo de especialistas concentrados em três áreas especificas: o uso de nanotecnologia na produção de alimentos e da transformação; o potencial para a saúde humana quanto aos riscos associados a essa utilização, e os elementos de dialogo construtivo entre as partes envolvidas na nanotecnologia, finalizaram o documento denominado The application of nanotechnologies in the food and agriculture sectors: potential food safety implications (2009). ${ }^{34}$

Nesse estudo, houve o reconhecimento de que a avaliação dos riscos utilizados pela FAO/OMS ${ }^{35}$ e adequada para os nanomateriais; no entanto, dado o diminuto tamanho das partículas, surgem novas características totalmente desconhecidas, que podem dar origem a perfis de toxicidade alterados. Assim, concluiu-se que as organizações parceiras desse estudo, devem continuar a rever suas estratégias de avaliação dos riscos, por meio de métodos diferenciados.

\footnotetext{
${ }^{33}$ GRUPO ETC. Tecnologia atômica: a nova frente das multinacionais. Trad. de Elisa Schreiner. São Paulo: Expressão Popular, 2004.

${ }^{34}$ FOOD AND AGRICULTURE ORGANIZATION OF THE UNITED NATIONS (FAO); WORLD HEALTE ORGANIZATION (OMS). The application of nanotechnologies in the food and agriculture sectors: Potential Food Safety Implications. 2009. Disponivel em:

$<$ http://www.fao.org/ag/agn/agns/expert_consultations/Nanotech_EC_Scope_and_Objectives .pdf - acesso em 22 março 2018.

${ }^{35}$ Organização Mundial da Saúde (OMS), a Organização das Nações Unidas para Alimentação e Agricultura (FAO)
} 
Na mesma linha, o Relatório da União Europeia sobre os aspectos regulamentares dos nanomateriais (2009), reconheceu, entre outros pontos, que os atuais conhecimentos acerca da toxicidade das nanoparticulas são limitados, além de não haver informações completas quanto aos riscos de diferentes nanoparticulas.

No tocante a segurança alimentar, a prevenção tem uma importância crucial para a mitigação dos riscos. Com o intuito real de estabelecer critérios de precaução, foi aditado um projeto de resolução legislativa do Parlamento Europeu A7-0152 (2010), relativo a novos alimentos, que entre outros pontos de modificação, destaca:

\begin{abstract}
Os alimentos a cuja produção tenham sido aplicados processos que exigem métodos de avaliação específicos (por exemplo, alimentos produzidos com nanotecnologias) não podem ser incluídos na lista comunitária enquanto esses métodos não tiverem sido aprovados para utilização e uma avaliação de segurança adequada com base nesses métodos não tiver demonstrado que a utilização dos respectivos alimentos é segura. [...] Os métodos de ensaio atualmente disponíveis não são adequados para avaliar os riscos associados aos nanomateriais. Deverão ser desenvolvidos urgentemente métodos de ensaio de nanomateriais que não utilizem animais. (Projeto de resolução legislativa do Parlamento Europeu A7-0152, 2010) ${ }^{36}$.
\end{abstract}

A partir das sugestões acima citadas da União Europeia, verifica se que a questão alimentar que diz respeito aos nanomateriais talvez seja a área que mais carece de pesquisas atualmente, além de apresentar uma serie de lacunas nos métodos de avaliação dos riscos para a saúde humana.

No atual ordenamento jurídico, constam normas uteis, apesar de gerais, como a Lei 6.437/77, que estabelece sanções as infrações a legislação sanitária federal; a Lei 9.782/99, que define o Sistema Nacional de Vigilância Sanitária e cria a Agencia Nacional de Vigilância Sanitária (Anvisa); as resoluções dessa agencia para remédios e segurança alimentar, normas internacionais da Organização Mundial de Saúde (OMS) e as Normas da Organização das Nações Unidas para a Alimentação e a Agricultura (FAO).

Além dessas normas, a Instrução Normativa Interministerial 1, de $1^{\circ}$ de abril de 2004, definiu os procedimentos complementares para aplicação do Decreto 4.680, de 24 de abril de 2003, que dispõe sobre o direito a informação, assegurado pela Lei 8.078, de 11 de setembro de 1990, quanto aos alimentos e ingredientes alimentares, destinados ao consumo humano ou animal, que contenham ou sejam produzidos a partir de Organismos Geneticamente

\footnotetext{
${ }^{36}$ Comunicação da comissão ao conselho, ao parlamento europeu e ao comitê econômico e social europeu sobre Nanociências e nanotecnologias: Plano de Ação para a Europa 2005-2009. COM (2005) Disponivel em: $<$ http://eurlex. europa.eu/LexUriServ/LexUriServ.do?uri=COM:2005:0243:FIN:PT:PDF>. Acesso em: 4 março 2018.
} 
Modificados, estabelecendo ainda um Regulamento Técnico que esta em anexo a Instrução Normativa.

No âmbito internacional, ainda existe o Codex Alimentarius, que e um compendio de normas alimentares, diretrizes e códigos de conduta internacionalmente acordados. A Comissão do Codex Alimentarius (CAC) ${ }^{37}$ sobre a normalização dos alimentos foi instituído pela Organização das Nações Unidas para a Alimentação e a Agricultura (FAO) e a Organização Mundial da Saúde (OMS), em 1962, com a intenção de proteger a saúde da população e assegurar praticas equitativas no comercio de alimentos. O Codex ajuda a harmonizar a legislação e as normas alimentares nacionais dos países que desejam usar seus textos como referencia.

No que concerne a verificação da existência de nanotecnologia na alimentação, não há como ser realizada atualmente, tanto pela falta de mecanismos, como pela inexistência de previsão legal no ordenamento pátrio, bem como tratados dos quais o Brasil faz parte. Resta clara a necessidade de adoção de Políticas Públicas no Brasil, referentes a aplicação da tecnologia "nano" em alimentos e na agricultura, ate que os riscos potenciais a segurança alimentar não puderem ser medidos e avaliados adequadamente.

\section{Considerações Finais}

O estudo do tema proposto possibilitou a ampliação do conhecimento a respeito da nanotecnologia, como um assunto que deve ser tratado e analisado de forma cautelosa e interdisciplinar, pois, quanto mais se adentrou no tema, maior foi a certeza de que se iniciava algo grandioso e que de modo algum haveria como esgotar o assunto.

Ao contrário, novas perspectivas foram visualizadas, e somente o tempo e o afinco no desenvolvimento desse tema na academia e na própria sociedade permitirão alinhar limites hoje desconhecidos.

De imediato foi constatada a dificuldade de buscar e desenvolver, como observador, a ruptura da visão linear para a entrada do viés sistêmico na discussão da proposta almejada, o que não foi óbice para o desenvolvimento do mesmo, e de indicar as diversas imbricações que a nanotecnologia propicia com os sistemas em seu entorno, uma vez que uma das principais

\footnotetext{
${ }^{37}$ COSBEY, Aaron. A forced evolution? The codex alimentarius commission, scientific uncertainty and the precautionary principle. Research paper, international institute for sustainable development, winnipeg, Canada. Disponivel em: <http://www.iisd.org/pdf/forced_evolution_codex.pdf $>$. Acesso em: 27 fevereiro 2018.
} 
características observadas foi justamente a convergência tecnológica que ampara a nanotecnologia.

Essa convergência demonstrou interações totalmente novas, como, por exemplo, a computação quântica, em que haverá componentes orgânicos (biologia) e inorgânicos (engenharia) dentro de um mesmo mecanismo, restando claro que o rompimento de paradigmas tradicionais levara a formação de áreas do conhecimento totalmente novas, bem como a formação de futuros pesquisadores/cientistas, pois a compreensão de somente uma área do conhecimento não bastara para o entendimento compreensão das interações esperadas.

Quando se pensa nos impactos da nanotecnologia sobre a sociedade e o meio ambiente, verifica-se que ainda não é possível responder a todos os campos possíveis, pois o potencial tecnológico revolucionará o padrão de sociedade que conhecemos, e haverá mudanças que alcançarão, desde a inovação da produção primaria, com técnicas de precisão na produção, através, por exemplo, de nano sensores interconectados, até a ampliação da expectativa de vida, pela implementação da nanomedicina na reprogramação dos genes, como a recuperação de ambientes bióticos e abióticos ${ }^{38}$.

Com a averiguação das relações que dizem respeito as diversas áreas da sociedade com a nanotecnologia, constatou-se a complexidade que envolverá o conhecimento e, a partir dessas constatações, foram abordadas algumas sugestões de "redução da complexidade".

Sob o viés do avanço tecnológico, foi possível verificar a escassez do debate publico em torno de questões de consumo. Restou clara a necessidade de adoção de Politicas Publicas no Brasil, referentes a aplicação da tecnologia "nano" em todas as áreas publicas, com destaque para aquelas que envolvem diretamente a saúde humana, tais como: a sanitária, a de alimentos, a do meio ambiente, bem como a incerteza sobre a metodologia necessária para a adequação das características mínimas para a grande quantidade de produtos já disponíveis no mercado para consumo.

No que se refere a busca de critérios de gestão do risco e regulamentação, por meio de normas jurídicas, constatou-se, referentemente a regulamentação, que, apesar de haver em nosso ordenamento jurídico um vasto arcabouço jurídico de leis, normas, decretos, resoluções, todos eles são gerais em relação a nanotecnologia, ou seja, acredita-se que poderiam ser utilizados, por analogia - como exemplo, cita-se a falta de informação em rótulos de produtos que contenham nanoelementos, a qual poderia ser suprida a partir da utilização de legislação consumerista -, por um lapso temporal, ate a criação de leis especificas a respeito dessa nova

\footnotetext{
${ }^{38}$ bióticos (seres vivos e sua relações), abióticos (elementos não vivos do ambiente).
} 
tecnologia. Como exposto inicialmente, o objetivo foi demonstrar e observar a legislação pertinente a discussão em torno da nanotecnologia e economia, analisando o direito da sociedade em vários aspectos,

No tocante a (auto)regulação, existe uma enorme interrogação, pois processos como o código de conduta responsável (responsible care) deixaria nas mãos das próprias industrias as matérias pertinentes ao desenvolvimento da nanotecnologia, cabendo a cada uma a responsabilidade dos produtos lançados; o mercado seria o agente decisivo na manutenção ou não de um produto.

Sob outra perspectiva, a auto(regulação) poderia desenvolver critérios de gestão de risco através das "agencias reguladoras", seguindo o modelo norte-americano. Em ambos os casos citados, as interrogações estão justamente em saber se essas realidades e possibilidades se adequariam a realidade brasileira, pois surgiram em realidades sociais totalmente diferentes das nossas.

Dada essa convergência tecnológica sobre a nanotecnologia, acredita-se que ainda não existe um mecanismo regulador genérico que possa responder aos anseios arguidos na pesquisa. Os riscos que advém do avanço das pesquisas em nanotecnologia somente tendem a aumentar; por outro lado, ha falta de discussão acerca do alcance de suas consequências.

Por essa razão, cabem imediatamente medidas de prudência fundadas no principio da precaução, não com o intuito de interromper/barrar o desenvolvimento tecnológico, mas para garantir e preservar os direitos básicos assinalados em nossa Carta Magna, como o respeito a vida e o direito a um meio ambiente ecologicamente equilibrado. A rigor, é possível aduzir que a humanidade nunca se defrontou com uma mudança que atingirá tantos segmentos sociais e de forma que acarretará mudanças drásticas na compreensão da própria vida.

\section{Referências bibliográficas}

BAUMAN, Zygmunt. Vida para o consumo: a transformação das pessoas em mercadorias.Trad. de Carlos Alberto Medeiros. Rio de Janeiro: J. Zahar, 2008.

EUROPA, Comunicação da comissão ao conselho, ao parlamento europeu e ao comitê econômico e social europeu sobre Nanociências e nanotecnologias: Plano de Ação para a Europa 2005-2009. COM (2005) Disponível em: <http://eurlex. europa.eu/LexUriServ/LexUriServ.do?uri=COM:2005:0243:FIN:PT:PDF>. Acesso em: 4 março 2018. 
.http://www.europarl.europa.eu/sides/getDoc.do?pubRef=//EP//TEXT+REPORT+A6 -2009-0255+0+DOC+XML+V0//PT - acesso em 24 de março de 2018.

COSBEY, Aaron. A forced evolution? The codex alimentarius commission, scientific uncertainty and the precautionary principle. Research paper, international institute for sustainable development, winnipeg, Canada. Disponivel em: $<$ http://www.iisd.org/pdf/forced_ evolution_codex.pdf $>$. Acesso em: 27 fevereiro 2018.

DUPONT NANO PARTNERSHIP ENVIRONMENTAL DEFENSE (ED - DuPont). 2007. Nano Risk Framework. Available. Disponivel em: $<$ http://www.environmentaldefense.org/ documents/6496_Nano\%20Risk\%20Framework.pdf>. Acesso em: 6 março 2018.

FAO; WORLD HEALTE ORGANIZATION - OMS. The application of nanotechnologies in the food and agriculture sectors: Potential Food Safety Implications. 2009. Disponivel em: $<\mathrm{http}$ //www.fao.org/ag/agn/agns/expert_consultations/Nanotech_EC_Scope_and_Objectives .pdf - acesso em 22 março 2018.

GARI, Manoel. Nano-amizades perigosas. 2010. Disponivel em: $<$ http://www.esquerda.net/ virus/index.php?option=com_content\&task=view\&id=146\&Itemid=26>. Acesso em: 15 março 2018.

GRUPO ETC. Tecnologia atômica: a nova frente das multinacionais. Trad. de Elisa Schreiner. São Paulo: Expressão Popular, 2004.

IIEP. Intercambio, informações, estudos e pesquisas. Princípios para a fiscalização de nanotecnologias e nanomateriais. Disponível em: $<$ http://www.iiep.org.br/nano /fundacentro/principles.pdf>. Acesso em: 12 março. 2018.

KELSEN, Hans. Teoria pura do direito. 6. ed. Trad. de Joao Batista Machado. São Paulo: M. Fontes, 2003. 
MOREIRA, Eliane Cristina P. Nanotecnologia e regulação: as inter-relações entre o direito e as ciências. In: MARTINS, Paulo Roberto (Org.). Nanotecnologia, sociedade e meio ambiente. São Paulo: Xama, 2006. p. 309-313

ROCHAEL, Carlos Henrique Reis. As agências de regulação brasileiras. 2004. Disponível em: <http://jus2.uol.com.br/doutrina/texto.asp?id=6822>. Acesso em: 22 março. 2018. 


\title{
SOCIEDADE INSTITUCIONAL NO DIREITO BRASILEIRO?
}

\author{
Alexandre de Albuquerque Sá \\ Doutor em Direito de Empresas e Atividades Econômicas pela UERJ
}

\begin{abstract}
Resumo
O presente estudo investiga se o institucionalismo foi adotado como modelo para formação do conceito de sociedade no direito brasileiro. Para tanto, são examinadas as principais correntes do institucionalismo existentes (publicista e integracionista), verificando-se sua compatibilidade com as normas societárias nacionais. Utiliza-se predominantemente o método dedutivo com pesquisa bibliográfica e documental, com abordagem teórica, valendo-se das fontes jurídicas ortodoxas, ou seja, legislação, doutrina especializada e jurisprudência dos tribunais pátrios.
\end{abstract}

Palavras-chave: Sociedade, natureza jurídica, institucionalismo, publicista, integracionista.

\section{Abstract/Resumen/Résumé}

This paper investigates whether institutionalism was adopted as a model for the formation of the concept of company in Brazilian law. In order to do so, the main currents of institutionalism (publicist and integrationist) are examined, and is verified their compatibility with national company norms. It is predominantly used the deductive method with bibliographical and documentary research, with theoretical approach, using the orthodox legal sources, that is, legislation, specialized doctrine and jurisprudence of the Brazilian Courts.

Keywords/Palabras-claves/Mots-clés: Company, legal nature, institutionalism, publicist, integrationist. 


\section{Introdução}

Inicialmente, salienta-se que a maior parte dos autores que estudam o direito societário brasileiro segue a orientação contratualista, notadamente na versão do contrato plurilateral ${ }^{1}$. Contudo, impende destacar que parcela considerável da doutrina afirma que, ao menos, alguns tipos societários adotam o modelo institucionalista, sobretudo os regulamentados na Lei $\mathrm{n}^{\mathrm{o}}$ $6.404 / 1976^{2}$.

De acordo com tal corrente, o perfil institucional das sociedades por ações estaria sinalizado especialmente no parágrafo único do art. 116 da Lei $\mathrm{n}^{\circ}$ 6.404/1976, o qual fixaria o dever de o acionista controlador exercer seus poderes para cumprir a função social da companhia ou comandita por ações, tendo obrigações e responsabilidades para com os demais sócios, os trabalhadores e a comunidade em que atua, dando um claro tom institucionalista a tais sociedade ${ }^{3}$.

Além disso, o vínculo entre os sócios não seria de natureza contratual, mas oriundo de um ato complexo, sendo necessário, portanto, o desencadeamento de diversos atos específicos para que seja constituída a instituição ${ }^{4}$. Justamente pela ausência da natureza contratual, o legislador teria optado na Lei $\mathrm{n}^{\circ}$ 6.404/1976, por utilizar o termo "estatuto social" em

\footnotetext{
${ }^{1}$ Assim é o entendimento de José Edwaldo Tavares Borba (2017, p. 30): "A doutrina do contrato plurilateral desfruta atualmente de uma posição dominante."

${ }^{2}$ Por exemplo, Fábio Ulhoa Coelho (2016, p. 26): “As sociedades contratuais são constituídas por um contrato entre os sócios. Isto é, nelas, o vínculo estabelecido entre os membros da pessoa jurídica tem natureza contratual, e em decorrência, os princípios do direito dos contratos explicam parte das relações entre os sócios. As institucionais também se constituem por um ato de manifestação de vontade dos sócios, mas não é este revestido de natureza contratual. Em decorrência, os postulados da teoria dos contratos não contribuem para a compreensão dos direitos e deveres dos membros da sociedade.

São contratuais as sociedades em nome coletivo, em comandita simples e limitada, e institucionais as sociedades anônima e em comandita por ações."

Igualmente, é o ministério do Sérgio Campinho (2010, p. 61): "São contratuais as sociedades limitadas, em nome coletivo e em comandita simples. As sociedades simples também são constituídas por contrato.

Institucionais são as sociedades anônima e em comandita por ações."

${ }^{3} \mathrm{Na}$ Exposição de Motivos, os autores do anteprojeto da Lei $\mathrm{n}^{\circ}$ 6.404/1976 sustentavam a importância da disposição nos seguintes termos: "O princípio básico adotado pelo Projeto, e que constitui o padrão para apreciar o comportamento do acionista controlador, é o de que o exercício do poder de controle só é legítimo para fazer a companhia realizar o seu objeto e cumprir sua função social, e enquanto respeita e atende lealmente aos direitos e interesses de todos aqueles vinculados à empresa - o que nela trabalham, os acionistas minoritários, os investidores do mercado e os membros da comunidade em que atua." (BRASIL, 1976, p. 1).

${ }^{4}$ Sérgio Campinho (2010, p. 60-61) leciona que: "As sociedades podem classificar-se, ainda, em razão da natureza de seu ato constitutivo, em sociedades contratuais ou institucionais.

Em ambos os tipos, a sociedade via se formar em função da manifestação volitiva de seus sócios. Nas contratuais, essa manifestação se assenta em um contrato celebrado entre os seus integrantes. Constitui-se, pois, por contrato entre os sócios. $\mathrm{O}$ vínculo é de natureza contratual. Nas institucionais, o vínculo já não vem revestido de natureza de contrato. $\mathrm{O}$ seu ato de criação não é um contrato, mas um ato complexo. Para sua formação são necessários vários atos, que se consubstanciam no seu ato constitutivo. Decorrem, assim, de um conjunto de atos dos fundadores para criar uma instituição."
} 
contraposição à expressão "contrato social" presente nas sociedades tratadas pelo Código Civil 5,6 .

Nesse sentido, este artigo pretende analisar as principais correntes históricas do institucionalismo (notadamente o publicista e o integracionista alemães), perscrutando se, de fato, o direito brasileiro adotou-o, plena ou parcialmente, como modelo do conceito de sociedade.

Estruturalmente, o texto se divide em seis partes: (i) a introdução; (ii) o estudo da contribuição de Maurice Hauriou, (iii) o institucionalismo publicista, (iv) o institucionalismo integracionista, (v) a síntese conclusiva e (vi) as referências utilizadas na elaboração do trabalho.

Outrossim, ressalta-se que a investigação foi baseada na metodologia de pesquisa bibliográfica e documental, averiguando-se os textos normativos positivados, as orientações da doutrina e a jurisprudência dos tribunais nacionais, empregando-se primordialmente o raciocínio dedutivo.

\section{A contribuição de Maurice Hauriou}

O movimento institucionalista, em um sentido mais amplo, tem como uma de suas principais referências o pensamento de Maurice Hauriou (2009), notadamente a obra "A teoria da instituição e da fundação - ensaio de vitalismo social", na qual o jurista francês procurou identificar o momento da formação do Estado e sua constituição formal, enfrentando a questão da criação das instituições e das regras de direito ${ }^{7}$.

\footnotetext{
${ }^{5}$ Conforme Fábio Ulhoa Coelho (2016, p. 27): "O instrumento disciplinar das relações sociais, nas sociedades contratuais, é o 'contrato social', enquanto nas institucionais é o 'estatuto'. Diverso também é o diploma jurídico aplicável na dissolução da sociedade: o Código Civil para as contratuais, e a Lei das Sociedades por Ações (Lei n. 6.404/76 - LSA) para as institucionais." (grifo do autor).

${ }^{6}$ Seção I

Do Contrato Social

Art. 997. A sociedade constitui-se mediante contrato escrito, particular ou público, que, além de cláusulas estipuladas pelas partes, mencionará:

$[\ldots]$

Parágrafo único. É ineficaz em relação a terceiros qualquer pacto separado, contrário ao disposto no instrumento do contrato.

${ }^{7}$ Ressalta-se que o institucionalismo não se limitou a influenciar apenas do direito societário, mas principalmente o direito público. De acordo com Maurício Moreira Menezes (2015, p. 52): "A Teoria da Instituição é em grande medida creditada ao trabalho filosófico de Maurice Hauriou, intitulado 'La théorie de l'institution et de la fondation', com grande influxo nos mais diversos campos do pensamento jurídico.

Assim, a construção de Hauriou nasceu no terreno do Direito Público, ganhou contornos de teoria geral e, enfim, foi transferida para o Direito Privado." (grifo do autor).
} 
Para responder a tal questionamento, o autor desenvolveu a tese de que o fundamento do Estado e o da regra de direito seriam os fundamentos do próprio direito, chegando à conclusão de que o objetivo essencial da teoria da instituição e da fundação seria demonstrar que a fundação das instituições apresenta um caráter jurídico.

Segundo Maurice Hauriou (2009), a instituição seria uma ideia (de obra ou de empresa $^{8}$ ), organizada, que existe juridicamente em um meio social, organizando-se um poder que lhe outorga órgãos para sua realização. Em paralelo, entre os indivíduos do grupo interessado na efetivação da ideia, geram manifestações de comunhão reguladas por procedimentos e administradas pelos órgãos de poder.

Tais instituições seriam classificadas em dois tipos distintos, as personificadas e as não-personificadas. Na primeira espécie, o poder organizado e as manifestações de comunhão são interiorizados no campo da ideia, tornando-se o sujeito da pessoa jurídica que surge do corpo constituído ${ }^{9}$. Nessa categoria de instituições-pessoas ou instituição corporativa, estariam enquadrados os Estados, as associações e as sociedades personificadas.

Já no segundo grupo, os elementos do poder organizado e as manifestações de comunhão permaneceriam fora do âmbito da ideia, não sendo interiorizados. Por conseguinte, não criariam uma pessoa jurídica própria, apenas se configurando como um princípio de limitação em oposição ao princípio de ação, característico das instituições-pessoa. Nessa categoria de instituição-coisa, se encontrariam, por exemplo, as regras de direito construídas socialmente e as sociedades não personificadas.

Feita a distinção, o autor francês concentra esforços para analisar apenas as instituições corporativas, afirmando que estas seriam compostas por três elementos: a ideia da obra (ou diretriz) a realizar em um agrupamento social, o poder organizado posto à disposição dela e as manifestações de comunhão relativas à ela e à sua efetivação.

O primeiro, e mais importante, seria a ideia da obra a realizar em um grupo social ou em seu benefício, pois todo corpo seria constituído para realização dessa obra ou de uma

\footnotetext{
${ }^{8}$ Impende, neste momento, frisar que Maurice Hauriou não utiliza o vocábulo "empresa" no sentido técnicojurídico de "atividade econômica organizada", mas de acordo com os significados aplicados pela linguagem leiga, isto é, variando entre sinônimo de sociedade, atividade e negócio.

${ }^{9}$ Assim expõe Maurice Hauriou (2009, p. 19-20): "Existem dois tipos de instituições, as que se personificam e as que não se personificam. Nas primeiras, que forma a categoria das instituições-pessoa ou dos corpos constituídos (Estados, associações, sindicatos, etc), o poder organizado e as manifestações de comunhão dos membros do grupo interiorizam-se no âmbito da idéia da obra: após ter sido o objeto da instituição corporativa, a idéia torna-se o sujeito da pessoal moral que se depreende do corpo constituído."
} 
empresa. O autor utiliza como exemplo uma companhia, argumentando que esta existiria para a "implementação de um negócio"10.

A ideia diretriz a realizar não poderia ser confundida com a noção de meta, pois esta última seria externa à corporação enquanto a primeira seria interior à mesma. Além disso, caberia salientar que, na ideia de obra a realizar, haveria um elemento de plano de ação e de organização com vistas à efetivação que transcenderia a noção de meta.

Quanto à diferença entre a ideia diretriz e a função, Maurice Hauriou defende que a função seria a parte já realizada ou, ao menos, já determinada da obra ou empresa. Na direção oposta, remanesceria, na ideia de obra a realizar, um campo indeterminado e virtual que iria além da função e não poderia ser contida nessa última.

Além disso, toda instituição dos corpos constituídos, para concretização de sua ideia diretriz, possuiria um grupo de interessados, ou seja, um conjunto de pessoas que adeririam à efetivação da obra ou da empresa, assumindo, consequentemente, um risco pela realização do fim pretendido.

Por sua vez, o segundo elemento das instituições-pessoa seria a organização da instituição, também, conhecida como o poder de governo organizado, o qual se direcionaria para concretização da ideia de obra ou de empresa. Esse poder seria organizado em uma pluralidade de órgãos, cada qual com as respectivas competências, de modo que o exercício do poder seria consubstanciado na interação harmoniosa entre tais órgãos ${ }^{11}$.

Nesse sentido, por exemplo, seriam as normas insculpidas nos arts. 1.069 e 1.070 da Lei $n^{\circ} 6.404 / 1976$ ao estabelecer as principais atribuições dos membros do conselho fiscal, além de determinar a indelegabilidade de suas funções e poderes a outros órgãos das sociedades anônimas.

Já o terceiro elemento seria a manifestação de comunhão dos membros do agrupamento e dos órgãos de governo, a qual se mostraria presente também na ideia da obra ou

\footnotetext{
${ }^{10}$ Para o jurista francês (2009, p. 21): "O elemento mais importante de toda instituição corporativa é o da idéia da obra a realizar num agrupamento social ou em proveito desse agrupamento. Todo corpo é constituído para a realização de uma obra ou de uma empresa. Uma sociedade anônima é a implementação de um negócio, ou seja, de uma empresa de especulação; um hospital é um estabelecimento constituído para a realização de uma idéia caritiva; um Estado é um corpo constituído para a realização de um certo número de idéias, as mais acessíveis das quais estão resumidas na seguinte fórmula: 'protetorado de uma sociedade civil nacional por uma potência pública com competência territorial, mas separada da propriedade das terras, e deixando assim uma grande margem de liberdade para os súditos."

${ }^{11}$ Segundo Hauriou (2009, p. 26): "O segundo elemento de toda instituição corporativa é, de fato, um poder de governo organizado que existe para a realização da idéia da empresa e a seu serviço. È o que se chama comumente de organização da instituição, mas é essencial interpretar a organização como um poder organizado, porque sendo o próprio poder uma forma da vontade, e considerando-se agora os órgãos apenas como poderes de vontade, isso espiritualiza o elemento humano da organização." (grifo do autor).
} 
empresa, como também nos meios que seriam utilizados para sua concretização, ou seja, na comunhão residiria a união de esforços e interesses em torno da efetivação da ideia diretriz.

As instituições, sejam públicas ou particulares, seriam instituídas e funcionariam por movimentos de comunhão de pessoas distintas, que se ligariam em um corpo para o cumprimento de um mesmo propósito. Elas se reuniriam por suas consciências individuais, passando ao estado subjetivo e, em conjunto, constituiriam em um novo corpo, isto é, a instituição formada a partir dessa união. Na comunhão, as consciências individuais agiriam como parte desse ente corporativo, focadas no objetivo coletivo.

Sem embargos, apesar de sua contribuição ser relevante ao movimento institucionalista, o jusfilósofo francês não trabalhou especificamente sobre os impactos de sua teoria nas sociedades, mas analisou o assunto de forma mais abrangente, mesclando questões de direito público e privado (MENEZES, 2015, p. 52).

Especificamente na seara do direito societário, a doutrina costuma classificar o institucionalismo em dois grandes grupos distintos (TEIXEIRA, 2010, p. 148). O primeiro denominado publicista, o qual teve seu maior desenvolvimento na Alemanha no final da primeira guerra mundial (SALOMÃO FILHO, 2011, p. 30-31) e o segundo designado por integracionalista, o qual está mais voltado à criação da organização mais apta à manutenção da atividade econômica (ID, 1995, p. 49). Observando tal categorização, começa-se com o exame da teoria institucionalista publicista.

\section{O institucionalismo publicista}

O institucionalismo publicista, de acordo com a literatura (FACCHIM, 2010, p. 61), possui como principal referência a tese da Unternehmen an sich (empresa em si ${ }^{12}$ ) desenvolvida por Walther Rathenau em artigo intitulado VomAktienwesen - Eine geschäftliche Betrachtung (Do sistema acionário - uma análise negocial) no Weltwirtschaftliches Archiv - Zeitschrift für Allgemeine und Spezielle Weltwirtschaftslehre (Arquivo Econômico Mundial - Revista de Economia Geral e Especial do Mundo ${ }^{13}$ ) em 1918.

O texto, elaborado por um homem de negócios (e não jurista), se encontra inserido no contexto da grave situação econômica da Alemanha no final da primeira guerra mundial,

\footnotetext{
${ }^{12}$ Utiliza-se com fonte primária no presente trabalho a tradução do artigo de Walther Rathenau realizada por Nilson Lautenschleger Junior. RATHENAU, Walther. Do sistema acionário - uma análise negocial. Tradução de: Nilson Lautenschleger Junior. Revista de direito mercantil, industrial, econômico e financeiro, São Paulo, v. 41, n. 128, p. 202-223, out./dez. 2002.

13 Tradução nossa.
} 
preocupando-se essencialmente em identificar o papel da sociedade anônima como importante instrumento para a reconstrução do país (LAUTENSCHLEGER JUNIOR, 2002, p. 200).

Em sua teoria, Walther Rathenau não utiliza o vocábulo "empresa" em seu sentido técnico de "atividade econômica organizada", normalmente o identificando como sinônimo de sociedade, tratando especialmente das companhias, tipo societário especialmente referido ao longo de seu trabalho (SALOMÃO FILHO, 2011, p. 31).

Inicialmente Walther Rathenau expõe sua visão sobre a economia alemã e seu desenvolvimento, afirmando que esta, por ser jovem e vigorosa, não poderia depender da riqueza de origem familiar, mas deveria escolher dar maior apoio às sociedades anônimas (notadamente as abertas), capazes de coletar recursos privados por meio das ações e debêntures, a fim de se vencer a forte concorrência técnica estrangeira e a sua produção em massa.

A sociedade familiar não seria talhada ao cumprimento dessa missão por duas ordens de motivos. A primeira, social, uma vez que a classe da população recém-enriquecida, controladora das sociedades, tenderia a modificar, a cada geração, seus ofícios e aspirações. Por outro lado, o próprio conceito de economia moderna implicaria em crescimento rápido e demandaria investimentos contínuos, os quais não poderiam ser arcados por agrupamentos familiares.

Nesse contexto, a teoria institucionalista publicista se vale da utilização do conceito de substituição de conteúdo (SubstitutiondesGrundes), segundo o qual as organizações humanas, apesar de manter o seu nome e algumas das suas características originais, poderiam passar por alterações em suas condições, objetivos e até mesmo na sua constituição original.

O autor alemão defende que a sociedade empresária também teria sido afetada por esse fenômeno, tornando-se algo distinto do que originalmente concebido pelos juristas e legisladores, evoluindo de uma típica estrutura familiar para a da grande sociedade, com as consequentes modificações na razão de ser e forma de atuar, ainda que mutações não fossem percebidas pela ciência jurídica, processo legislativo ou jurisprudencial.

À guisa de exemplo, Walther Rathenau (2002, p. 204) afirma que, ao adotar-se o modelo da grande sociedade, teria havido uma série de transformações fáticas nas responsabilidades do conselho de administração (conselho de supervisão na nomenclatura alemã), não obstante a manutenção do suporte legislativo formal.

Isso teria ocorrido porque o comando geral dessas sociedades estaria muito mais vinculado à diretoria, composta por profissionais altamente qualificados e dedicados exclusivamente a isto, já que não seria possível aos membros do conselho de supervisão tomar 
conhecimento de todas as operações mais importantes da grande sociedade em razão da complexidade e do tempo necessário para cumprimento de tal tarefa.

Além disso, de acordo com a teoria institucionalista publicista, a figura do grande acionista teria perdido espaço nessas novas sociedades. Nelas o capital social se encontraria altamente pulverizado, não designando, ao menos na mesma proporção que antes, a composição do conselho de administração, o qual teria passado a ser formado majoritariamente por financistas, especialistas técnicos ou jurídicos e demais conhecedores de negócios.

A grande sociedade não deveria ser vista como um organismo econômico egoísta, voltado para si, mas como um elemento ligado à economia do país, devendo confluir os interesses dos sócios, da sociedade e do Estado, além de exercer influência nos setores próximos a fim de resguardar suas fontes de insumos ${ }^{14}$.

Segundo tal corrente, o fenômeno da substituição de conteúdo também teria atingido o órgão supremo da companhia: a assembleia geral. Nas pequenas sociedades, os poucos sócios poderiam ter eventualmente conflitos decorrentes de opiniões técnicas diferentes, sem, contudo, configurar conflitos profundos entre eles e a própria sociedade. Também não se cogitaria na continuação da sociedade após o falecimento ou retirada dos fundadores.

Já a grande sociedade tenderia a se perpetuar no tempo, sendo suas ações sujeitas de serem herdadas ou, de algum outro modo, transferidas a novos sócios, de modo que a companhia poderia inserida em um contexto de permanência irrestrita, desvinculada à existência dos acionistas instituidores ${ }^{15}$.

Nessa conjuntura, haveria essencialmente duas classes de indivíduos que adquiririam as ações da sociedade anônima: o primeiro grupo seria composto por compradores que almejariam o rendimento pelo capital investido; o segundo esperaria pelo recebimento de ganho de capital.

\footnotetext{
${ }^{14}$ Nilson Lautenschleger Junior (2002, p. 200-201) resume bem esse quadro: "Com uma descrição minuciosa e muito próxima da realidade à época, inclusive sobre os desfavores da guerra, apresenta o que chama de substituição de conteúdo (SubstitutiondesGrundes) da sociedade por ações, isto é, a mudança do conteúdo, aqui as relações econômicas, sem que haja a mudança da foram, aqui a regulamentação da sociedade por ações.

Tendo a grande empresa como base as determinantes da economia, conclui pela preponderância da maioria - algo muitas vezes não compreendido - e pela importância da empresa em si (Unternehmen na sich), como centro de convergência dos interesses dos acionistas, da sociedade e do Estado. É controverso, ainda hoje, se sua concepção da empresa em si (a enfant terrible do direito societário, nos dizeres de Laux, ob. cit., infra) não seria uma pura e simples reação contra os excessos da democracia acionária pela qual se almejava a limitação dos poderes dos acionistas frente à administração, limitação esta que legitimaria com a proteção de interesses próprios da empresa, algo, à época, inadmissível." (grifo do autor).

${ }^{15}$ Consoante Walther Rathenau (2002, p. 208): “Já era existente a semente da mudança na medida que a empresa não era pessoal. Permanecia anônima e era certamente destinada a continuar a existir mesmo quando seus fundadores morressem ou se retirassem. Por isso, eram as participações passíveis de serem legadas e transferidas. Originalmente, não se ousava pensar em uma duração de existência irrestrita, isto é, em um conceito de existência absoluta e independente dos proprietários."
} 
O primeiro segmento seria integrado predominantemente por grandes administradores de patrimônio, que não visariam a troca constante de valores mobiliários com fins especulativos, e escolheriam seus investimentos após detalhada análise das condições financeiras e estruturais da companhia. Inexistiriam, em vista disso, grandes conflitos entre esses sócios e a administração da sociedade, uma vez que seus interesses normalmente estariam em confluência com os da pessoa jurídica.

Por outro lado, a segunda categoria seria constituída por especuladores, os quais não adquiririam as ações com o objetivo de investimento a longo prazo, mas para alienar rapidamente de acordo com a elevação de sua cotação em bolsa. Estes sócios não se importariam com os fundamentos econômico-financeiros da companhia, nem seus interesses estariam alinhados aos sociais, pois se consubstanciariam basicamente na majoração do preço das ações para a revenda.

Assim sendo, Walther Rathenau (2002, p. 211) faz uma importante crítica à doutrina e à jurisprudência de seu tempo, alegando que estas estariam voltadas apenas à análise da relação entre acionistas controladores e minoritários, não percebendo que o real problema estaria na oposição dos interesses entre os sócios especuladores e os interesses confluentes dos sócios permanentes e da companhia.

Para essa variação da teoria institucionalista, não haveria necessidade de uma proteção própria aos acionistas minoritários em relação aos majoritários por sua condição diferenciada, já que os direitos destes se resumiriam aos de representação e voto nas assembleias e nos demais órgãos congêneres.

Dessa forma, haveria uma democracia do capital voltada ao atendimento do melhor interesse publicista da sociedade. O tratamento especial adviria apenas em caso de lesão de direitos, o qual também poderia afetar a maioria societária, quando o real interesse da sociedade não fosse devidamente atendido.

Para essa corrente doutrinária, o interesse da sociedade, causado pela substituição de conteúdo, não poderia ser reduzido a interesses privados dos sócios, devendo ser visto como um fator da economia, pertencente à comunidade nacional, ainda que mantenha em sua origem resquícios de uma sistemática vocacionada meramente à obtenção de lucro.

A sociedade empresária existiria para o atendimento das necessidades econômicas. Sua função vital seria um método temporal econômico, de modo em que a estrutura societária poderia ser reconfigurada conforme as necessidades específicas de um determinado povo em 
uma etapa específica da história, especialmente em situações críticas como um contexto de guerra ou reestruturação dos meios de produção ${ }^{16}$.

Neste ponto, frisa-se que essas discussões do papel das sociedades se referem essencialmente à realidade da Europa, especialmente da Alemanha no período das duas grandes guerras mundiais (FACCHIM, 2010, p. 62), a qual não se confunde com o momento vivenciado pelo Brasil na mesma época.

Além disso, a doutrina (SALOMÃO FILHO, 2011, p. 32) informa que o institucionalismo publicista entrou em decadência a partir da década de 1950, notadamente devido às críticas à ideia de predominância da administração sobre a assembleia dos acionistas então em voga no direito tedesco.

Do ponto de vista normativo, a lei acionária de 1965 robusteceu o papel da assembleia geral e os direitos dos sócios minoritários na Alemanha Ocidental ${ }^{17}$, marcando significativamente o momento de transição para a teoria institucionalista integracionista, a qual se passa a examinar.

\section{O institucionalismo integracionista}

Inicialmente, recorda-se que o institucionalismo integracionista surgiu de uma progressiva evolução da doutrina alemã rediscutindo o papel das sociedades e a as relações jurídicas existentes entre ela, seus sócios, seus empregados e a comunidade como um todo, especialmente no período compreendido entre a entrada em vigor das leis alemães sobre as sociedades por ações de 1937 e 1965 (SALOMÃO FILHO, 2011, p. 32).

\footnotetext{
${ }^{16} \mathrm{O}$ economista Rathenau (2002, p. 215) sustenta que: "Não teria sido possível comandar nem mesmo por seis meses a guerra que fazemos se as grandes empresas alemãs não tivessem provado sua capacidade para reestruturação que era necessária para se disponibilizar noventa por cento das fábricas alemãs para a indústria armamentista e multiplicar por cem a produção de material de defesa.

$[\ldots]$

Se nos detivermos mais ao conceito vital da grande empresa, pois nos convencemos de que na antiga pela do negócio comercial de caráter privado e há muito emancipada da economia utilitarista pura lhe foram impostas tarefas que são de economia comunal, estatais e políticas, então, podemos reclamar deste ente transitório todo o desenvolvimento de Estado socialista, e quando isto corresponde ao nosso convencimento teórico, então não precisamos nos deparar com a autonomização e estatização. Entretanto, enquanto a estrutura existir em sua atual forma, precisamos protegê-la contra seu estilhaçamento pelo particularismo dos interesses privados, não importando se, assim, eventuais intenções de especular são frustradas. Temos que analisar, sobretudo, suas condições de existência e cuidar para que tais condições sejam mantidas para o bem comum sem violação dos direitos individuais."

${ }^{17}$ Consoante Calixto Salomão Filho (2011, p. 32): "Tal teoria entrou em crise a partir dos anos 50, sendo criticada sobretudo pelo segundo aspecto [predominância da administração sobre a assembleia de acionistas], denominado negativo e que se traduz em uma tendencial independência (e irresponsabilidade) da administração com relação aos acionistas. A reação completou-se com a lei acionária de 1965, que reforçou o papel da Assembléia dos acionistas e os direitos dos acionistas minoritários." (grifo do autor).
} 
Esse intervalo de tempo é conhecido especialmente pela proliferação de normas que buscam conceder maior participação dos trabalhadores nos principais órgãos das sociedades anônimas (TEIXEIRA, 2010, p. 151), como nos conselhos fiscal e de administração, entre as quais se pode citar, por exemplo, a Gesetzes über die Mitbestimmung der Arbeitnehmer in den Aufsichtsräten und Vorständen der Unternehmen des Bergbaus und der Eisen und Stahl erzeugenden Industrie (Lei sobre a cogestão dos trabalhadores nos conselhos fiscal e de administração das sociedades da indústria de mineração, do ferro e aço ${ }^{18}$ ), de 21 de maio de 1951.

De certo modo, doutrina integracionista veio como uma resposta às críticas formuladas em relação à Lei das Sociedades por Ações de 1937, a qual, segundo seus opositores, careceria, tanto sobre o prisma jurídico como político-econômico, de dispositivos que garantissem a aplicação efetiva dos princípios institucionalistas (SALOMÃO FILHO, 2011, p. 33).

Especificamente no aspecto jurídico, questionava-se uma possível incoerência entre as premissas da teoria da "empresa em si", a qual reconheceria a existência de diversos interesses no bojo da companhia, como os dos sócios, empregados e da coletividade, com o fato de que a tutela de tais interesses estaria confiada a um conselho de administração, designado, sobretudo, pelos acionistas controladores, o que impediria, muitas vezes, a concretização da imparcialidade que se esperava desse órgão societário ${ }^{19,20}$.

\footnotetext{
${ }^{18}$ Tradução nossa.

${ }^{19}$ Para Pier Giusto Jaeger (1964, p. 47-48): "Durante a investigação sobre a teoria de Rathenau e de seus seguidores, uma das críticas que surgiu com maior frequência para a doutrina da Unternehmen an sich [empresa em si]: a de não ser consistente com as consequências em si, postulando o reconhecimento, na disciplina da sociedade por ações, de diferentes categorias de interesses, de trabalhadores, de sócios e da coletividade, confiando a proteção de todos esses interesses ao Vorstand [conselho de administração], órgão inidôneo, pela natureza de emanação do grupo de controle, para realizar essa delicada tarefa com a necessária imparcialidade. A evolução doutrinária, sobre esse ponto, é um dos aspectos mais interessantes, também porque contribuiu para a introdução, no sistema de direito positivo, de normas que proporcionam aos trabalhadores uma representação no Aufsichtsrat [conselho de supervisão] da sociedade e, pelo menos, para certos ramos da atividade econômica, mesmo no órgão de administração (por exemplo, Mitbestimmung [cogestão]). A Mitbestimmung é certamente o mais recente fato da legislação alemã relativo aos problemas deste estudo no período em questão, e é o que mais influenciou a doutrina, a qual foi atribuída a tarefa de qualificar conceitualmente o instituto no sistema de direito acionário." (tradução nossa). (grifo do autor).

${ }^{20} \mathrm{O}$ texto em língua estrangeira é: "Si è accennato, nel corso dell'indagine sulla teoria del Rathenau e dei suoi seguaci, a una delle accuse che più frequentemente venivao rivolte alla dottrina dell'Unternehmen an sich: quella di non essere coerente alle premesse da essa stessa aftermante, che postulano il riconoscimento, nella disciplina della società per azioni, di diverse categorie di interessi, dei lavoratori, dei soci e della colletività, affidando la tutela di tutti questi interessi al Vorstand, organo inidoneo, per la sua natura di emanazione dei grupi di controllo, ad esplicare questo delicato compito con la necessaria imparzialità. La evoluzione dottrinale presenta, su questo punto, uno degli aspetti più interessanti, anche perchè ad essa ha corrisposto l'introduzione, nel sistema del diritto positivo, di norme che concedono ai prestatori di lavoro una rappresentanza nell'Aufsichtsrat della società e, almeno per determinati rami di attività economica, anche nell'organo diretivo (c.d. Mitbestimmung). La Mitbestimmung è certamente il fatto più nuovo della legislazione tedesca relativa ai problemi di questo studio, nel periodo che qui interessa, ed è quello che maggiormente ha influenzato la dottrina, cui è stato posto il compito di qualificare concetuualmente l'istituto nel sistema del diritto azionario." Ibid.
} 
Por outro lado, cabe salientar que o surgimento das leis que reconheciam o direito de cogestão dos trabalhadores se deu no ambiente pós-segunda guerra mundial, no qual os Estados ocupantes (Reino Unido, França e Estados Unidos) e os sindicatos de empregados entendiam por conveniente a descartelização da economia da Alemanha Ocidental, além do abrandamento da forte centralização das instâncias de poder então existente na indústria daquele país (MOTTA, 1983, p. 30).

Com a introdução das leis que regulamentam a cogestão (Mitbestimmungsgesetze), houve a consagração do institucionalismo no direito societário da República Federal da Alemanha (GEßLER; HEFERMEHL; ECKARDT; KROPFF, 1973, p. 5), sendo que o interesse social passou a ser traduzido como o conjunto harmonioso dos interesses dos sócios e dos trabalhadores no espírito da preservação da atividade econômica (MERTENS, 1977, p. 270), superando, desse modo, o traço extremamente publicizado da teoria da "empresa em si" (Unternehmen an sich) outrora predominante (TEIXEIRA, 2012, p. 71).

Como consequência dessa nova roupagem para o institucionalismo, mais voltado a uma visão organizativa da sociedade do que à manutenção da sociedade como instituição, perceber-se-ia um cuidado menor em resguardar o conceito de personalidade jurídica do que antes, dando-se margem ao aparecimento e expansão da teoria da desconsideração da personalidade jurídica em terras germânicas (TEIXEIRA, 2010, p. 152) ${ }^{21}$.

Igualmente, convém destacar que, de acordo com a doutrina (SALOMÃO FILHO, 2011, p. 35), o modelo societário alemão, ao contemplar a participação dos empregados na administração social, teria elaborado uma acepção de interesse social não norteada apenas aos interesses dos sócios, como propunha o contratualismo clássico, mas voltada à preservação da atividade negocial.

Desse modo, teria sido oportunizada a discussão sobre o tipo de organização mais eficiente para o atendimento dessa nova noção de interesse da sociedade, daí o institucionalismo integracionalista ser também designado por "institucionalismo organizativo".

Ademais, recorde-se que, diversamente da proposta do contrato plurilateral, no institucionalismo integracionista o conflito de interesses, mesmo que presente em muitos casos, não poderia ser considerado elemento fundamental para a elucidação da forma de funcionamento das dinâmicas societárias, haja vista que o institucionalismo seria baseado na

\footnotetext{
${ }^{21}$ Sobre a teoria da desconsideração da personalidade jurídica no direito alemão, recomenda-se a leitura da obra "Rechtsform und Realität juristischer Personen" (Forma e realidade da pessoa jurídica) de Rolf Serick. (tradução nossa). SERICK, Rolf. Rechtsform und Realität juristischer Personen. Tubinga: Mohr Siebeck, 1955.
} 
ideia da cooperação de todos os envolvidos (sócios, administradores e empregados) em prol do interesse e da preservação da sociedade (SALOMÃO FILHO, 2011, p. 35).

Contudo, isso não significa que o institucionalismo organizativo tenha conseguido o ensejo de efetivamente eliminar os conflitos existentes dentro de uma sociedade. De forma diversa, ao redefinir o interesse social como algo maior que o interesse dos sócios, sendo uma justa composição dos interesses desses e dos trabalhadores com vistas à preservação da atividade econômica, os confrontos se intensificaram, além de serem trazidos para o interior dos órgãos societários, haja vista a participação dos empregados nos conselhos fiscal e de administração (BONELL, 1983, p. 387).

Nesse contexto, destaca-se que a teoria da instituição organizativa não elaborou uma tese específica sobre o ato de constituição das sociedades, se preocupando, sobretudo, com a identificação do interesse social como a melhor forma de organização da atividade econômica parar atender os interesses conjunto dos sócios e trabalhados com vistas à preservação da atividade negocial.

Entretanto, não obstante os argumentos apontados por parcela da doutrina ${ }^{22}$ no sentido de que alguns tipos societários adotariam o modelo institucionalista, sobretudo os dispostos na Lei ${ }^{\circ}$ 6.404/1976 (as companhias e as sociedades em comandita por ações), não parece correto afirmar que o Brasil tenha efetivamente adotado tal corrente ainda que parcialmente.

Cumpre lembrar que consta, como um dos argumentos em favor da suposta base institucionalista da Lei n ${ }^{\circ}$ 6.404/1976, a justificativa apresentada pela Presidência da República ao solicitar ao Congresso Nacional que examinasse a nova regulamentação das sociedades por ações em procedimento legislativo apartado do Projeto de Lei da Câmara dos Deputados $n^{\circ}$ 634/1975, que originou o Código Civil de 2002. Para tais autores, o documento elaborado pelo Poder Executivo teria deixado clara a intenção de conceder um viés institucionalista a essas sociedades $^{23}$.

\footnotetext{
${ }^{22}$ Segundo, por exemplo, Fábio Ulhoa Coelho (2016, p. 26): “As sociedades contratuais são constituídas por um contrato entre os sócios. Isto é, nelas, o vínculo estabelecido entre os membros da pessoa jurídica tem natureza contratual, e em decorrência, os princípios do direito dos contratos explicam parte das relações entre os sócios. As institucionais também se constituem por um ato de manifestação de vontade dos sócios, mas não é este revestido de natureza contratual. Em decorrência, os postulados da teoria dos contratos não contribuem para a compreensão dos direitos e deveres dos membros da sociedade.

São contratuais as sociedades em nome coletivo, em comandita simples e limitada, e institucionais as sociedades anônima e em comandita por ações."

Igualmente, Sérgio Campinho (2010, p. 61): "São contratuais as sociedades limitadas, em nome coletivo e em comandita simples. As sociedades simples também são constituídas por contrato.

Institucionais são as sociedades anônima e em comandita por ações."

${ }^{23}$ Conforme Rubens Requião (2015, p. 14-15): "A orientação oficial passou, portanto, a considerar a sociedade anônima como instrumento da grande empresa moderna, tendo-se ressaltado, ainda, naquela exposição, que 'a lei de sociedade anônima - lei da grande empresa - depende do funcionamento correlato de várias instituições
} 
Sem embargo, cumpre recordar que tal orientação não permaneceu no Projeto de Lei da Câmara $n^{\circ}$ 2.559/1976 (posteriormente convertido na Lei $n^{0}$ 6.404/1976), nem tampouco se encontrava presente na Exposição de Motivos no 196/1976 do Ministério da Fazenda, remetendo à análise presidencial o Anteprojeto de Lei elaborado por comissão de juristas liderada por Alfredo Lamy Filho e José Luiz Bulhões Pedreira.

Nesse ponto, impende frisar que o próprio José Luiz Bulhões Pedreira (1998, p. 114) esclareceu que a proposta apresentada em 1976 não se sedimentava em uma visão institucionalista da sociedade. Pelo contrário, as sociedades por ações, para o coautor do Anteprojeto, teriam permanecido estruturadas sob o contrato de sociedade, excetuando-se apenas as subsidiárias integrais, as quais seriam constituídas por meio de negócio jurídico unilateral, sem jamais se consubstanciar em instituição ${ }^{24}$.

Por outro lado, ressalta-se que há autores, como Rubens Requião (2015, p. 15), defendendo a possibilidade de conciliação entre as duas correntes, sustentando a tese da existência de uma sociedade anônima de viés institucionalista, ainda que fosse constituída por contrato plurilateral.

econômicas de interesse público; é parte de um todo que tem que ser disciplinado harmonicamente. Com efeito, a sociedade anônima só pode alcançar as finalidades de instrumento jurídico da grande empresa - essencial no processo de desenvolvimento econômico brasileiro - se e quando seu funcionamento estiver coordenado com o do Banco Central, o da bolsa de valores e todo o sistema financeiro nacional.

$[\ldots]$

Ao raciocinar em termos de sociedade anônima como estrutura da grande empresa moderna, o pensamento oficial propendeu a fundamentar filosoficamente os estudos da reforma na teoria da instituição, formulada por Hauriou. $[\ldots]$

Essa posição doutrinária, como se disse, foi adotada pelas autoridades brasileiras na "Exposição de Motivos" a que aludimos anteriormente, em que traçaram os princípios doutrinários e os propósitos básicos da reforma." (grifo do autor).

${ }^{24}$ Essas são as lições de José Luiz Bulhões Pedreira (1998, p. 114): “A análise da área de autonomia da vontade que continua a existir na companhia deixa evidente que a ela não se aplica esse conceito de instituição, pois a constituição e o funcionamento da companhia pressupõe muito mais do que a vontade de criar a companhia exclusivamente nos temos de um estatuto legal.

$[\ldots]$

É inquestionável, entretanto, que o papel da autonomia de vontade do contrato de companhia é bem mais restrito do que na maioria dos negócios jurídicos nominados, dada a quantidade de normas legais imperativas, mas esse fato não decorre de peculiaridades na natureza jurídica da companhia, e sim da importância da função social desempenhada por esse tipo de contrato e pelas repercussões que suas características implicam sobre terceiros e o sistema econômico.

$[\ldots]$

A controvérsia sobre a natureza jurídica é improcedente, ao menos no direito brasileiro: a lei a regula como modalidade de contrato de sociedade comercial e seu regime não se ajusta ao conceito doutrinário de instituição jurídica, no sentido usado pela doutrina francesa, uma vez que o modelo legal de companhia somente pode ser adotado mediante a consumação de um contrato (salvo no caso de constituição de subsidiária integral, quando o modelo é usado mediante negócio jurídico unilateral e só se transforma em contrato quando admitido outro acionista". 
Considera-se, todavia, altamente problemática essa proposta, haja vista que as duas teorias são baseadas em visões completamente distintas do interesse social e das relações intrassocietárias, o que levaria, inevitavelmente, a contradições insuperáveis.

Essas incompatibilidades decorrem, por exemplo, do fato de que o sistema contratual plurilateral pressupõe que os direitos e deveres das partes se apresentem simultaneamente ligados entre todos os integrantes, havendo, nesse conjunto global, uma justa composição de direitos e obrigações (ASCARELLI, 1969, p. 268).

Ainda assim, o conceito ora referido se mostra inconciliável com a vertente institucionalista já tratada, visto que esta última não se direciona de forma prioritária à promoção ou à conciliação dos interesses dos sócios, mas vincula o interesse social a questões estranhas a eles, como os interesses da comunidade em geral ou dos trabalhadores (RATHENAU, 2002, p. 214), não contemplando a dinâmica pretendida pelos contraentes ao celebrar um contrato.

Igualmente, não se pode olvidar que a corrente institucionalista de Maurice Hauriou, a qual, segundo Rubens Requião (2015, p. 14), teria influenciado os autores da lei brasileira das sociedades por ações, possui uma explicação própria para criação de instituições, fundada em ato complexo composto pelos estágios de incorporação e personificação, não compatível em si com a ideia de contrato (HAURIOU, 2009, p. 37-39).

Ademais, entende-se improcedente a argumentação de que o perfil institucional das sociedades por ações estaria plasmado, sobretudo, no parágrafo único do art. 116 da Lei $\mathrm{n}^{\circ}$ 6.404/1976, o qual fixou o dever de o acionista controlador exercer seus poderes de acordo com o interesse da companhia, tendo este obrigações e responsabilidades para com os demais sócios, os trabalhadores e a comunidade em que atua.

A bem da verdade, as obrigações estabelecidas no citado dispositivo legal são comandos no sentido do cumprimento da função social da sociedade, conforme assentam os autores do projeto na respectiva Exposição de $\operatorname{Motivos}^{25}$, e não havendo introjeção da teoria da instituição no direito societário brasileiro.

Nesse contexto, cabe sempre recordar que, no atual estágio da ciência jurídica, os institutos de direito privado (incluídos os contratos), não devem ser concebidos apenas de

\footnotetext{
${ }^{25} \mathrm{Na}$ Exposição de Motivos, os autores do anteprojeto da Lei $\mathrm{n}^{\mathrm{0}}$ 6.404/1976 sustentavam a importância da disposição nos seguintes termos: "O princípio básico adotado pelo Projeto, e que constitui o padrão para apreciar o comportamento do acionista controlador, é o de que o exercício do poder de controle só é legítimo para fazer a companhia realizar o seu objeto e cumprir sua função social, e enquanto respeita e atende lealmente aos direitos e interesses de todos aqueles vinculados à empresa - o que nela trabalham, os acionistas minoritários, os investidores do mercado e os membros da comunidade em que atua." (BRASIL, 1976, p. 1)
} 
acordo com os interesses egoístas, mas devem cumprir sua função social (MARTINS-COSTA, 2005 , p. 41), com fito de atender diversas normas constitucionais nesse sentido, como os arts. $3^{\circ}$, I, $5^{\circ}$, XXIII e art. 170, III, da Constituição da República.

Essa visão solidarizada das sociedades é também anunciada por parte da doutrina (WALD, 2000, p. 61), revelando que a sociedade anônima não poderia mais ser vista sob o prisma de um capitalismo brutal e de curto prazo, mas orientada para uma visão mais humanizada e de médio e longo prazos, buscando harmonizar diversas classes de interesses, como as dos sócios, trabalhadores e da comunidade.

De outro giro, nem tampouco se coaduna com a ideia de que a sociedade por ações poderia ser constituída por intermédio de ato complexo ${ }^{26}$ correspondente ao processo de incorporação propagado por Maurice Hauriou (2009, p. 37) especialmente na hipótese em que os fundadores se socorrem da poupança popular através do lançamento público de ações (constituição por subscrição pública nos termos do art. 82 e seguintes da Lei no 6.404/1976).

Em realidade, mesmo nesse caso, a estrutura das sociedades por ações pluripessoais se demonstra contratual, pois o ato de subscrição de ações se consubstancia em verdadeiro contrato de adesão, no qual o subscritor adere ao contrato, com fito de participar da constituição da sociedade $^{27}$.

Além disso, salienta-se que a teoria da instituição não foi capaz de desvendar adequadamente as relações existentes entre os membros no bojo das sociedades, apenas a proposição do contrato plurilateral conseguiu elucidar a correlação de direitos e deveres dos sócios (MENEZES, 2015, p. 77).

Conforme as lições de Tullio Ascarelli (1969, p. 256) as sociedades seriam contratos marcados pela possibilidade de participação de mais de duas partes, todas assumindo direitos e obrigações entre si, além de possuir um cunho instrumental, haja vista que estabeleceriam uma disciplina de cooperação entre os sócios.

\footnotetext{
${ }^{26}$ Sérgio Campinho (2010, p. 60-61) leciona que: "Nas institucionais, o vínculo já não vem revestido de natureza de contrato. $\mathrm{O}$ seu ato de criação não é um contrato, mas um ato complexo. Para sua formação são necessários vários atos, que se consubstanciam no seu ato constitutivo. Decorrem, assim, de um conjunto de atos dos fundadores para criar uma instituição."

${ }^{27}$ Nas palavras de Rubens Requião (2015, p. 131): "O ato de subscrição, não temos dúvida, constitui um negócio jurídico bilateral. Configura um contrato de adesão, no qual o subscritor, assinando a lista, boletim ou carta em separado, adere ao contrato, visando à constituição da sociedade anônima. A outra parte contratante não é a sociedade, pois ainda está em formação, não tendo nascido; o contrato se forma com os fundadores. Tanto isso é exato, que o art. 92 estabelece que os fundadores e as instituições financeiras que participarem da constituição por subscrição pública responderão, no âmbito das respectivas atribuições, pelos prejuízos resultantes da inobservância de preceitos legais. Responderão os fundadores solidariamente pelo prejuízo que causarem, decorrente de culpa ou dolo em atos ou operações anteriores à constituição."
} 
Quanto à relação entre as partes, no contrato plurilateral, não haveria propriamente obrigações de uma parte em relação a uma outra, mas deveres de uma parte para com todas as outras partes, de forma conjunta, sendo essa característica mais um elemento de distinção entre esses contratos e os sinalagmáticos.

Além disso, os interesses das várias partes de um contrato plurilateral deveriam ser unificados com o fito de atingir uma finalidade comum ${ }^{28}$. Nesse sentido, tais contratos poderiam ser vistos como contratos com comunhão de fim, pois a parte se obrigaria simultaneamente com todas as outras, e para com todas elas adquiria direitos. Assim, seria natural coordená-las em torno de um fim, de um escopo conjunto ${ }^{29}$.

Nos contratos plurilaterais, o fim seria juridicamente relevante, em sua precisa configuração para cada caso específico (como, verbi gratia, na constituição de uma sociedade para exercer a atividade de importação e exportação de mercadorias). Constituiria o elemento unificador de várias adesões e concorreria para determinar os direitos e deveres das partes. Desse modo, o escopo se vincularia àquela atividade ulterior, a qual o contrato plurilateral é destinado.

Nessa conjuntura, o principal direito dos sócios seria precisamente compartilhar o resultado do exercício da atividade econômica. Tal proposição estaria de acordo com a legislação em vigor, pois, tanto o Código Civil no art. 1.008, como a Lei das Sociedades por Ações no art. 109, I, fixam como direito essencial dos sócios a participação do lucro social, sendo nula qualquer estipulação que inviabilize esse direito.

Entretanto, no que tange aos deveres, as obrigações poderiam ter um objeto distinto, sem, todavia, formar um conteúdo típico constante, como ocorre normalmente nos contratos bilaterais (SILVA, 2003, p. 54). Isto é, se, na hipótese da compra e venda, cada parte possuiria uma obrigação de conteúdo típico, como pagar o valor ou entregar a coisa, já nas sociedades em base plurilateral, cada sócio poderia contribuir com bens ou serviços, sendo essa a orientação, por exemplo, do Código Civil conforme seu art. 981, respeitadas as limitações do tipo adotado e das previsões do contrato ou estatuto social.

\footnotetext{
${ }^{28}$ Pessoalmente, prefere-se a locução "fim social" em vez de "fim comum" para poder contemplar as hipóteses de sociedades unipessoais. No mesmo sentido é o ministério de Erasmo Valladão Azevedo e Novaes França e Marcelo Vieira von Adamek (2008, p. 130): "Eis que, numa sociedade unipessoal, não se poderia falar, a rigor, de um fim comum." (grifo dos autores).

${ }^{29}$ Segundo Tullio Ascarelli (1969, p. 271): “A pluralidade corresponde a circunstância de que os interesses contrastantes das várias partes devem ser unificados por meio de uma finalidade comum; os contratos plurilaterais aparecem como contratos com comunhão de fim. Cada uma das partes obriga-se, de fato, para com tôdas as outras, e para com tôdas as outras adquire direitos; é natural, portanto, coordená-los todos, em torno de um fim, de um escopo comum."
} 


\section{Considerações finais}

Neste artigo, foram analisadas as duas principais correntes do institucionalismo societário (publicista e integracionista), chegando-se à conclusão de que se tratam de concepções jurídicas historicamente vinculadas especialmente ao contexto alemão do século $\mathrm{XX}$.

Nesse sentido, defendeu-se que o institucionalismo publicista se encontra inserido no ambiente da grave situação econômica da Alemanha no final da primeira guerra mundial, preocupando-se essencialmente em identificar o papel da sociedade (sobretudo a anônima de grande porte) como instrumento para o esforço bélico e para a reconstrução do país.

Já o institucionalismo integracionista é resultado das circunstâncias presentes após o fim da segunda guerra mundial, no qual os Estados ocupantes (Estados Unidos, Reino Unido e França) e os sindicatos de empregados entendiam necessária a descartelização da economia da República Federal da Alemanha.

Esses atores também promoveram a mitigação da centralização das instâncias de poder então existente na indústria tedesca, notadamente por meio da edição de normas que buscam conceder maior participação aos trabalhadores nos principais órgãos societários, como os conselhos fiscal e de administração.

Por fim, assentou-se que essas experiências jurídicas alemãs não possuem intensa relação com as opções político-legislativas adotadas no âmbito do direito comercial brasileiro, tendo o legislador pátrio seguido a orientação contratualista, notadamente na versão do contrato plurilateral, na elaboração das normas das sociedades pluripessoais.

\section{Referências bibliográficas}

ASCARELLI, Tullio. Problemas das sociedades anônimas e direito comparado. 2. ed. São Paulo: Saraiva, 1969.

ASQUINI, Alberto. Perfis da empresa. Revista de direito mercantil, industrial, econômico e financeiro, São Paulo, v. 35, n. 104, p. 109-126, out./dez. 1996.

BARTHOLO, Bruno Paiva; GAMA, Guilherme Calmon Nogueira da. Função social da empresa. Revista dos tribunais, São Paulo, v. 96, n. 857, p. 11-28, mar. 2007. 
BONELL, Michael Joachim. Partecipazione operaia e diritto dell'impresa. Profili comparatistici. Milão: Giuffrè, 1983.

BORBA, José Edwaldo Tavares. Direito societário. 15. ed. São Paulo: Atlas, 2017.

BRASIL. Ministério da Fazenda. Exposição de motivos no 196. Brasília, DF, 24 de junho de 1976.

BULGARELLI, Waldirio. Sociedades, empresa e estabelecimento. São Paulo: Atlas, 1980.

CAMPINHO, Sérgio. O direito de empresa à luz do novo código civil. 11. ed. Rio de Janeiro: Renovar, 2010.

CARVAlHOSA, Modesto; EIZIRIK, Nelson. A nova lei das s/a. São Paulo: Saraiva, 2002.

COELHO, Fábio Ulhoa. Curso de Direito Comercial. 20. ed. São Paulo: Saraiva, 2016. 3 v. V. 2: Sociedades.

DUGUIT, Pierre Marie Nicolas Léon. Les transformations genérales du droit prive depuis le code napoléon. Paris: Félix Alcan, 1912.

FACCHIM, Tatiana. A sociedade unipessoal como forma organizativa da micro e pequena empresa. 2010. 126 f. Dissertação (Mestrado em Direito Comercial) - Faculdade de Direito, Universidade de São Paulo, São Paulo, 2010.

FRACAROLLI, Luiz Machado. O sistema normativo da companhia. Revista de direito mercantil, industrial, econômico e financeiro, São Paulo, v. 45, n. 142, p. 25-55, abr./jun.2006.

FRANÇA, Erasmo Valladão Azevedo e Novaes; ADAMEK, Marcelo Vieira von. Affectio societatis: um conceito jurídico superado no moderno direito societário. Revista de direito mercantil, industrial, econômico e financeiro, São Paulo, v. 47, n. 149-150, p. 108-130, jan./dez. 2008. 
(Org.). Direito Societário Contemporâneo I. São Paulo: Quartier Latin, 2009.

FRAZÃO, Ana. Empresa e propriedade - função social e abuso de poder econômico. São Paulo: Quartier Latin, 2006.

GEßLER, Ernst; HEFERMEHL, Wolfgang; ECKARDT, Ulrich; KROPFF, Bruno. Aktiengesetz. Kommentar. Munique: Franz Halen, 1973. 11 v. V. 11: §§ 262-277.

HAURIOU, Maurice. A teoria da instituição e da fundação: ensaio de vitalismo social. Tradução de: José Ignácio Coelho Mendes Neto. Porto Alegre: Sergio Antonio Fabris, 2009.

JAEGER, Pier Giusto. L’interesse sociale. Milão: Giuffrè, 1964.

JOÃO, Juliana. Evolução histórica das sociedades empresárias. In: BERALDO, Leonardo de Faria (Org.). Direito societário na atualidade. Belo Horizonte: Del Rey, 2007. p. 15-23.

LAUTENSCHLEGER JUNIOR, Nilson. Relato breve sobre Walther Rathenau e sua obra: 'a teoria da empresa em si'. Revista de direito mercantil, industrial, econômico e financeiro, São Paulo, v. 41, n. 128, p. 199-202, out./dez. 2002.

MARTINS-COSTA, Judith. Reflexões sobre o princípio da função social dos contratos.

Revista direito GV, São Paulo, v. 1, n. 1, p. 41-66, mai. 2005.

MENEZES, Mauricio Moreira. Companhia institucional? In: TAVARES, Marcelo Leonardo (Org.). Empresa e atividades econômicas. Rio de Janeiro: Freitas Bastos, 2015. p. 47-78.

MERTENS, Hans-Joachim. Zuständigkeiten des mitbestimmten Aufsichtsrat. Zeitschrift für das gesamte Handelsrecht und Wirtschaftsrecht, Frankfurt, n. 141, p. 270-286, jan./fev. 1977.

MOTTA, Fernando Cláudio Prestes. A co-gestão alemã: as conciliações do inconciliável. Revista de administração de empresas, Rio de Janeiro, v. 23, n. 1, p. 23-36, jan./mar. 1983. 
MUNHOZ, Eduardo Secchi. Empresa contemporânea e o direito societário. São Paulo: Juarez de Oliveira, 2002.

NALIN, Paulo Roberto Ribeiro. Do contrato: conceito pós-moderno (em busca de sua formulação na perspectiva civil-constitucional). Curitiba: Juruá, 2001.

PEDREIRA, José Luiz Bulhões. Natureza jurídica da companhia. Revista de direito Renovar, Rio de Janeiro, n. 12, p. 105-120, set./dez. 1998.

RATHENAU, Walther. Do sistema acionário - uma análise negocial. Tradução de: Nilson Lautenschleger Junior. Revista de direito mercantil, industrial, econômico e financeiro, São Paulo, v. 41, n. 128, p. 202-223, out./dez. 2002.

REQUIÃO, Rubens. Curso de direito comercial. 34. ed. São Paulo: Saraiva, 2015. 2 v. V. 1: Introdução ao estudo do direito comercial.

SALOMÃO FILHO, Calixto. A sociedade unipessoal. São Paulo: Malheiros, 1995. . O novo direito societário. 4. ed. São Paulo: Malheiros, 2011.

SERICK, Rolf. Rechtsform und Realität juristischer Personen. Tubinga: Mohr Siebeck, 1955.

SILVA, Alexandre Antonio Bruno da. O regime dos contratos comerciais plurilaterais no código civil de 2002. Revista opinião jurídica, Fortaleza, v. 1, n.1, p. 50-57, jan./dez. 2003.

TEIXEIRA, Ana Bárbara Costa. A empresa-instituição. 2010. 272 f. Dissertação (Mestrado em Direito Comercial) - Faculdade de Direito, Universidade de São Paulo, São Paulo, 2010.

TEIXEIRA, Eric Fonseca Santos. A limitação da responsabilidade do empresário individual: a sociedade unipessoal. 2012. 150 f. Dissertação (Mestrado em Direito) Faculdade de Direito, Universidade Federal de Minas Gerais, Belo Horizonte, 2012. 
WALD, Arnoldo. A evolução do direito societário. Revista de direito mercantil, industrial, econômico e financeiro, São Paulo, v. 39, n. 120, p. 56-65, out./dez. 2000. 


\section{DIREITO TRIBUTÁRIO E FINANCEIRO}

\section{APRESENTAÇÃO}

Novamente, em terras de Espanha, país de história e cultura incomparável, nos deparamos com reflexões articuladas nos trabalhos apresentados cuja síntese resume toda a angústia de uma sociedade, de um pais e toda uma coletividade destinatária e objeto de uma tributação que indene de propostas de alteração ainda remanesce sobremaneira de difícil entendimento e de árduo diálogo entre o Estado exator e o sujeito passivo. Os trabalhos apresentados, cada qual buscando uma vertente original e propositiva, vertem necessariamente para questões que envolvem o equilíbrio entre a necessidade premente, inafastável e crescente do EstadoAdministração de recursos financeiros para fazer frente às suas atribuições apresentadas, mormente em época de eleições gerais como a vivenciada pelo país em 2018, como atrativo ou chamariz para convencimento do eleitor iludido com promessas e juras de um Estado provedor cujo orçamento não só apresenta-se engessado - considerando não só as despesas obrigatórias crescentes, como no caso daquelas capituladas como correntes, associadas à previdência social e de ordem salarial bem como a implantação, via emenda constitucional do teto orçamentário de despesas para um ano fiscal sob a limitação da inflação do ano anterior - não havendo, segundo é decantado ao mundo espaço para aumento da carga tributária. Portanto, o que fazer? Cabe-nos um papel acadêmico de formulação de alternativas que não sejam meramente afirmar que a tributação deve ser reduzida, aumentada ou alterada. No mesmo sentido, também não nos caberia apontar, de forma impositiva, quais despesas devam ser reduzidas ou suprimidas daquelas sob a égide estatal. O problema posto é mais profundo. O que a sociedade pretende com o Estado que a regula? O que podemos definir como sociedade em tempos em que convivemos com um universo paralelo virtual? Como o indivíduo, integrante desta sociedade, poderia abdicar de pretensos direitos em prova da coletividade? Como grupos específicos poderiam reagir à uma carga tributária inédita a eles direcionada? O que nos espera de fato nos próximos anos são cada vez desafios mais complexos onde o direito financeiro e tributário serão cada vez mais provocados e reformulados. Parabéns a todos os articulistas deste livro e que permaneçam cientes e atentos aos compromissos por todos nós assumidos de repensar a área financeira estatal cujo escopo é permitir o mínimo de ordem e justiça social. 
Coordenadores do GT:

Prof. Dr. Raymundo Juliano Feitosa - UNICAP

Prof. Dr. Antônio Carlos Diniz Murta - FUMEC 


\title{
A TRANSPARÊNCIA NA TROCA DE INFORMAÇÕES ENTRE A ADMINISTRAÇÃO TRIBUTÁRIA E OS CONTRIBUINTES NO CONTEXTO DA AÇÃO 12 DO PLANO BEPS
}

\author{
Renata Gomes de Albuquerque Sá \\ Doutoranda em Direito pela Universidade de Coimbra
}

\begin{abstract}
Resumo
Este artigo pretende tecer comentários à ação de número 12 do Plano BEPS, explicando a necessidade de uma maior transparência na relação entre a administração tributária dos países e os contribuintes, a fim de coibir o planejamento tributário abusivo. Em seguida, abordaremos os países nos quais as regras de "mandatory disclosure" foram implementadas, com destaque para a tentativa brasileira, através da Medida Provisória 685/2015, trazendo a opinião da doutrina sobre o tema.
\end{abstract}

Palavras-chave: Transparência, Informações, Tributos, Beps, Receita.

\begin{abstract}
Resumen/Résumé
This article intends to comment on BEPS Plan action number 12, explaining the need for greater transparency in the relationship between the tax administration of the countries and the taxpayers, in order to restrain abusive tax planning. Next, we will address the countries in which the mandatory disclosure rules were implemented, with emphasis on the Brazilian attempt, through Provisional Measure 685/2015, bringing the opinion of the doctrine on the subject.
\end{abstract}

Keywords/Palabras-claves/Mots-clés: Transparency, Information, Taxes, Beps, Revenue. 


\section{Introdução}

O presente artigo propõe um estudo sobre a ação $n^{\circ} 12$ proposta pela OCDE no contexto do Plano BEPS, o qual tem por objetivo o combate ao planejamento fiscal abusivo no plano internacional, determinando uma maior transparência na relação entre as administrações tributárias dos países e os contribuintes.

Na primeira parte, abordaremos o tema da concorrência fiscal prejudicial entre os países, explicando o contexto de elaboração do Plano BEPS, com enfoque na ação $\mathrm{n}^{\mathrm{o}} 12$, fazendo uma reflexão crítica do seu conteúdo e trazendo a opinião da doutrina nacional e internacional sobre o tema.

Na segunda parte, trataremos da diferenciação dos conceitos de elisão, evasão e tentaremos definir o significado da expressão "planejamento fiscal agressivo", que vem sendo utilizada no âmbito das discussões dos países da OCDE e pelos principais doutrinadores da área tributária.

Finalmente, na terceira parte, verificaremos os reflexos de tal proposição nos países membros da OCDE e no Brasil, especialmente a tentativa de regulamentação desta medida através da edição da Medida Provisória $n^{0}$ 685/2015, analisando suas consequências no ordenamento jurídico pátrio e trazendo a opinião dos autores sobre tal proposta.

\section{A ação 12 do Plano BEPS}

É inegável que a globalização trouxe inúmeros benefícios para as nações, como a livre circulação de bens, serviços e pessoas, aumentando o investimento nos países e diminuindo a pobreza, especialmente ao se verificar que o ritmo de integração das economias e mercados nacionais tem aumentado exponencialmente nos últimos anos.

Por consequência, a forma de estruturação das empresas multinacionais também vem se modificando, com a criação de modelos globais baseados em organizações com estrutura matricial e cadeias de suprimento integradas que centralizam várias funções em escala regional e mundial (OCDE, 2014, p. 7-8).

Contudo, o principal efeito negativo dessa questão se dá no que se refere à harmonização entre os diferentes sistemas fiscais dos países onde operam as grandes empresas multinacionais. Cada nação possui suas regras específicas de tributação e, em muitas hipóteses, surgem lacunas na interação entre dois ou mais sistemas, o que poderia levar a uma dupla 
tributação, ou a uma dupla não-tributação, ou, ainda a múltiplas não-tributações, com consequências adversas ao crescimento e à prosperidade global.

Nessa atual conjuntura, associada às dificuldades encontradas pelos países de lidar com as novas organizações societárias utilizadas pelas empresas multinacionais para reduzir ou evitar a tributação, os países integrantes do G-20 e a Organização para a Cooperação e Desenvolvimento Económico ou Econômico (OCDE) elaboraram um plano de ação para tentar solucionar a questão da erosão da base tributária e da transferência de lucros de maneira coordenada e abrangente.

Nesse contexto, no ano de 2013 surgiu o Projeto BEPS (Base Erosion and Profit Shifting), que tem por foco o combate à elisão fiscal que prejudique o desenvolvimento econômico das nações, com a apresentação do relatório Addressing Base Erosion and Profit Shifting, que aprofundou a análise sobre o tema da erosão das bases tributáveis para apresentação aos países integrantes do G-20, e do relatório Action Plan on Base Erosion and Profit Shifting (OCDE, 2013, p. 5), no qual apresenta um plano com quinze ações destinadas a solucionar os principais focos de BEPS.

Destaca-se, por oportuno, o conteúdo da ação de $\mathrm{n}^{\circ} 12$, a qual prevê a necessidade de que sejam desenvolvidas orientações aos contribuintes para que estes noticiem seus planejamentos tributários agressivos às administrações tributárias dos países, com prazo de implementação até setembro de 2015.

Segundo a OCDE, a assimetria das informações sobre as regras de transfer princing entre os contribuintes e os Fiscos dos países prejudica a livre concorrência e aumenta as chances de se verificar a erosão da base tributária e de transferência de lucros nas transações por eles realizadas.

Isso porque, em muitos países, as administrações tributárias não possuem capacidade de adquirir uma visão global da cadeia de valor mundial de um contribuinte, especialmente se tratando de grandes empresas. Outrossim, as divergências entre as abordagens de cada nação, no que concerne às exigências de documentação em matéria de preços de transferência gera um alto custo para as empresas que operam em escala mundial (OCDE, 2014, p. 24).

Nesse contexto, a obrigação do disclosure prevista nessa ação ressalta a importância de que os contribuintes disponibilizem à administração tributária informações adequadas sobre as funções relevantes realizadas por outros membros do grupo de empresas multinacionais, no tocante a serviços e outras transações intragrupo (OCDE, 2014, p. 24-25).

Aduz-se, por oportuno, que o princípio da transparência se traduz na necessidade de uma publicação clara das regras aplicáveis pela Administração Fiscal, para que estas possam 
ser invocadas pelos contribuintes, traduzindo-se ainda, na necessidade de disponibilidade por parte de outras jurisdições dos detalhes de aplicação prática dessas mesmas regras (AZEVEDO, 2010, p. 795).

No caso de tributação, a Organização Mundial do Comércio, destaca que o referido princípio se compõe por quatro elementos fundamentais: a descrição do tipo de medida fiscal adotada; sua função e objetivos, o seu custo (ou benefício) em termos de receita fiscal e a sua avaliação econômica em termos de eficácia na prossecução dos objetivos pretendidos (TEIXEIRA, 2010, p. 65).

No entanto, a expressão "planejamento fisscal agressivo", utilizada na redação da OCDE, gera muitas críticas na doutrina mundial e por parte dos autores brasileiros. Ademais, existe um grande temor por parte dos particulares em relação a que tipo de uso será feito dessas informações por parte da Administração Tributária, o que prejudica a segurança jurídica em tais situações. Tais questões serão enfrentadas nos próximos tópicos deste trabalho.

\section{Limites do planejamento fiscal}

Heleno Taveira Torres (2001, p. 36-37) ensina que planejamento tributário é uma técnica de organização preventiva de negócios, realizada pelos contribuintes, com o fito de obter uma legítima economia de tributos, mediante a utilização de todas as oportunidades lícitas para tanto.

O objetivo precípuo do planejamento fiscal será a economia de tributos, sem o cometimento de ilícitos. Nesse sentido, deve o administrador de negócios perseguir o aumento da renda e a diminuição dos custos operacionais, que aliado a um planejamento tributário bem elaborado, se torna possível.

Esse planejamento lícito também é referido pela doutrina como elisão fiscal que, segundo Paulo Ayres Barreto (2010, p. 1051), consiste no direito subjetivo do sujeito passivo de, por meios lícitos, evitar a ocorrência do fato jurídico tributário, diminuir o montante devido a título de tributos, ou, ainda, postergar sua incidência.

Como afirma Ricardo Lobo Torres (2012, p. 10), o contribuinte tem plena liberdade para a estruturação de seus negócios, sendo livre para optar pela organização e formatação de sua empresa de modo a lhe permitir economia de impostos. Ele tem o direito de eleger a via menos onerosa, de buscar a opção mais adequadas aos seus interesses.

Essa concepção é aceita na maioria dos países. No entanto, surgem inúmeros questionamentos quando é verificado um planejamento que tem por objetivo a economia de 
tributos a qualquer custo, sendo esta a principal (ou as vezes, única) motivação para prática de determinados atos, isto é, quando é realizado o denominado planejamento tributário ofensivo ou agressivo (BORGES, 2007, p. 78).

Cumpre, nessa seara, distinguir essa noção da ideia de evasão físcal, contraponto da elisão, e que se caracteriza pela conduta do contribuinte de, por meios ilícitos (nos termos da legislação tributária), de evitar a ocorrência do fato jurídico tributário, reduzir o montante devido a título de tributo, ou postergar a sua incidência (BARRETO, 2010, p. 1052).

Paulo de Barros Carvalho (2011, p. 83) esclarece, ainda, que a evasão "decorre de operações simuladas em que, ocorrido o fato de relevância jurídica para o direito tributário, pretende-se ocultá-lo, mascarando o negócio jurídico”. Hermes Marcelo Huck (1997, p. 31), por sua vez, entende a evasão como sinônimo de fraude fiscal.

Note-se que o planejamento fiscal agressivo não se confunde com a evasão, como bem salienta Martinez (2017, p. 108):

\begin{abstract}
A entidade mais agressiva tributariamente, ao realizar uma transação, assegura-se de que é utilizada em cada oportunidade a opção que permite minimizar os impostos. Quando opera em regimes onde a lei fiscal é incerta ou aberta a interpretação, tenderá a assumir a posição fiscal que lhe seja mais favorável. Ao estruturar suas transações, sempre buscará as formas e alternativas que garantem a maior economia tributária. Ocorre que, em determinadas situações, essa conduta pode assumir posições juridicamente duvidosas, e que aos olhos da autoridade tributária podem ser interpretadas, inobstante legítimas na sua forma, como abusiva.
\end{abstract}

A ideia de planejamento agressivo é vista como sinônimo de planejamento físcal abusivo, que é a escolha, pelo contribuinte, de negócios jurídicos fiscalmente menos onerosos que, apesar de lícitos, são antijurídicos, ainda que não ocorra violação frontal à norma (AMORIM, 2017, p. 18).

Merece destaque, ainda, as lições de Capone e Valadão (2014, p. 274):

As legislações tributárias dos diversos países foram evoluindo no sentido de contemplarem normas antielisivas específicas para evitar o abuso das mencionadas estratégias, como é o caso das normas de preços de transferência, a inserção de cláusulas anti-abuso nos tratados, restringindo sua utilização aos que tem efetivo domicílio e são destinatários das rendas beneficiadas pela eliminação da duplatributação pelos países signatários, adoção das normas restringindo o diferimento das coligadas e controladas no exterior (normas CFC) e mesmo a adoção da denominada norma-geral antielisiva, de forma a combater estratégias de planejamento tributário que se utilizam de arranjos normativos privados lícitos, mais de forma abusiva. 
Saliente-se que, a Comissão Europeia, dezembro de 2012, estabeleceu algumas recomendações aos Estados Membros relativamente ao planejamento fiscal abusivo, afirmando que ele consiste em "um aproveitamento de aspetos técnicos de um sistema ou da incompatibilidade entre dois ou mais sistemas fiscais, a fim de reduzir as obrigações fiscais" (UNIÃO EUROPEIA, 2012, p. 1).

A seguir, a Comissão destaca algumas consequências que podem advir desta prática, como as duplas deduções (hipótese em que a mesma perda é deduzida tanto no Estado da fonte como no Estado de residência, por exemplo) e a dupla não tributação (a exemplo de rendimentos não tributados no Estado da fonte e que são isentos de imposto no Estado de residência) (UNIÃO EUROPEIA, 2012, p. 1).

Destaca-se que é nesse sentido que a expressão "planejamento fiscal agressivo" é utilizada pela OCDE em seus relatórios contra a erosão da base tributária. No contexto do BEPS, o planejamento fiscal agressivo vem sendo entendido como a postura adotada pelas multinacionais para reduzir sua carga tributária mediante a interação das regras de diferentes ordenamentos jurídicos, como uma ideia vaga (que pode se referir a situações de elisão ou evasão) e que demanda a coordenação fiscal internacional (DOURADO, 2016, p. 296).

\section{Resultados da ação 12 do BEPS nos países membros da OCDE}

Merece destaque o fato que diversos países já implementaram regras de disclosure, tais como Portugal, Canadá, Irlanda, Reino Unido e os Estados Unidos.

Portugal, desde 2008, já conta com o Decreto 29/2008, de 25 de fevereiro, designado pela doutrina do país como a lei de planejamento fiscal. Seu objetivo precípuo é tornar do conhecimento pela Administração Fiscal os esquemas de planejamento tributário abusivo, para que esta, em seguida, promova alterações nas leis e regulamentos que considere adequadas (VIEIRA, 2014, p. 29).

Entende-se que a colaboração entre fisco e os contribuintes, auxiliará o desenvolvimento do processo legislativo ou a produção de instruções administrativas, conseguindo um aperfeiçoamento das normas jurídico-fiscais e uma rigorosa aplicação (LOUREIRO; NEVES, 2008, p. 5).

Outrossim, esse diploma alerta para as consequências do planejamento físcal agressivo ou abusivo, o qual gera efeitos desfavoráveis bastante significativos, corrói os sistemas fiscais, desencoraja o cumprimento por parte dos contribuintes das suas obrigações tributárias e 
aumenta injustificadamente os custos administrativos de fiscalização da máquina fiscal (VIEIRA, 2014, p. 29).

O mesmo decreto define e delineia o conceito de planejamento fiscal abusivo, no seu artigo $3^{\circ 1} \mathrm{e}$, em seu artigo $4^{\circ 2}$, dita os esquemas ou atuações que estão abrangidos pela obrigação de comunicação prévia. Note-se que o dever de divulgação é tanto do promotor como do utilizador do esquema (VIEIRA, 2014, p. 30-31).

No Canadá, por sua vez, existem dois tipos de transações que são suscetíveis de conduzir a um planejamento tributário ilícito, quando o sujeito passivo contrata os serviços de um promotor com o compromisso de confidencialidade em relação a outros indivíduos ou à administração fiscal e quando o contribuinte contrata os serviços de um promotor pagando remunerações contingentes (CANADA, 2009, p. 6).

Outrossim, se a transação em um ano civil ou em um ano fiscal resultar em um benefício igual ou superior a vinte e cinco mil dólares para o contribuinte ou um benefício igual ou superior a cem mil dólares para a empresa, o contribuinte deve divulgar a transação às autoridades responsáveis (CANADA, 2009, p. 7); se o contribuinte não divulgar a transação, ele terá de pagar uma multa no valor de dez mil dólares e que aumentará mil dólares diariamente, até ao montante máximo de cem mil dólares (CANADA, 2009, p. 13).

\footnotetext{
${ }^{1}$ Artigo 3. ${ }^{\circ}$ Planeamento fiscal

Para efeitos do disposto no presente decreto-lei, considera-se:

a) «Planeamento fiscal», qualquer esquema ou actuação que determine, ou se espere que determine, de modo exclusivo ou predominante, a obtenção de uma vantagem fiscal por sujeito passivo de imposto;

b) «Esquema», qualquer plano, projecto, proposta, conselho, instrução ou recomendação, exteriorizada expressa ou tacitamente, objecto ou não de concretização em acordo ou transacção;

c) «Actuação», qualquer contrato, negócio ou conjunto de negócios, promessa, compromisso, estrutura colectiva ou societária, com natureza vinculativa ou não, unilateral ou plurilateral bem como qualquer operação ou acto jurídico ou material, simples ou complexo, realizado, a realizar ou em curso de realização;

d) «Vantagem fiscal», a redução, eliminação ou diferimento temporal de imposto ou a obtenção de benefício físcal, que não se alcançaria, no todo ou em parte, sem a utilização do esquema ou a actuação.

${ }^{2}$ Artigo 4. ${ }^{\circ}$ Esquemas ou actuações abrangidos

1 - Estão sujeitos ao disposto no presente decreto-lei os esquemas ou actuações de planeamento fiscal, tal como definidos no artigo anterior, que se reconduzam a uma das situações seguintes:

a) Impliquem a participação de entidade sujeita a um regime fiscal privilegiado, considerando-se como tal a entidade cujo território de residência conste da lista aprovada por portaria do Ministro das Finanças ou quando aí não for tributada em imposto sobre o rendimento idêntico ou análogo ao IRS ou ao IRC ou ainda quando o imposto efectivamente pago seja igual ou inferior a $60 \%$ do imposto que seria devido se a referida entidade fosse considerada residente em território português;

b) Impliquem a participação de entidade total ou parcialmente isenta;

c) Envolvam operações financeiras ou sobre seguros que sejam susceptíveis de determinar a requalificação do rendimento ou a alteração do beneficiário, designadamente locação financeira, instrumentos financeiros híbridos, derivados ou contratos sobre instrumentos financeiros;

d) Impliquem a utilização de prejuízos fiscais.

2 - Independentemente da correspondência com uma das situações referidas no número anterior, estão sempre sujeitos ao disposto no presente decreto-lei os esquemas de planeamento fiscal, tal como definidos no artigo anterior, que sejam propostos com cláusula de exclusão ou de limitação da responsabilidade em benefício do respectivo promotor.
} 
$\mathrm{Na}$ Irlanda a divulgação antecipada de esquemas é realizada majoritariamente pelos promotores, que divulgam os esquemas que tenham como objetivo principal uma vantagem tributária. Cora O'Brien (2011, p. 2) afirma que tais esquemas recaem sobre uma das quatro descrições pré-estabelecidas, como desejo de confidencialidade da transação de outros promotores ou da administração fiscal, prémio ou remuneração extra ao promotor pela realização da transação, documentação normalizada sujeita a exceções específicas ou se a transação está incluída num certo tipo de transações, a exemplo da conversão de renda em capital.

O promotor deve divulgar o esquema no prazo de cinco dias após comercializá-lo ou quando este estiver disponível para a implementação por outra pessoa; no caso do contribuinte o prazo de divulgação é de cinco dias após a primeira transação do esquema, sob pena de multa diária de quinhentos euros, acrescida de outra penalidade de cinquenta euros por dia (OCDE, 2011, p. 20).

Já o Reino Unido determinou a obrigação de divulgação antecipada relativamente ao imposto sobre a renda, sobre a sociedades e sobre mais-valias fiscais, às contribuições para a segurança nacional, ao imposto de selo sobre a terra, ao imposto anual sobre moradias e ao imposto sobre heranças.

O promotor deverá comunicar previamente um esquema sempre que o sujeito passivo espere obter uma vantagem tributária com aquela transação e desde que preenchidos alguns dos hallmarks transcritos nos regulamentos ${ }^{3}$, até o quinto dia anterior à realização da transação (REINO UNIDO, 2013, p. 18).

Em algumas situações, o contribuinte poderá ser responsável pela divulgação, passando a ter a obrigação de divulgar o esquema no período de cinco a trinta dias após a realização da primeira transação, caso o promotor esteja sediado fora do Reino Unido, ou caso o promotor seja advogado e não divulgue a totalidade da informação em razão do sigilo profissional ou, ainda, caso inexista promotor, de modo que o contribuinte é o responsável pela implementação do esquema (REINO UNIDO, 2013, p. 19).

Nos Estados Unidos, são cinco as categorias de transações que são alvo de obrigação de disclosure, sendo consideradas potenciais operações de planejamento fiscal ilícito, as quais

\footnotetext{
3 São elas: transações confidenciais e inalcançáveis para concorrentes na área, transações confidenciais e inalcançáveis para as autoridades fiscais, transações que envolvem produtos financeiros, transações que envolvem produtos estandardizados, transações que envolvam prejuízos fiscais, transações que envolvam determinadas operações de leasing.
} 
sejam: transações listadas, transações confidenciais, transações com proteção contratual, transações com interesse, ou transações que envolvam prejuízos fiscais (KORB, 2005, p. 62).

O promotor tem a obrigação de divulgação da informação, identificando-a e descrevendo-a, bem como informando os potenciais benefícios fiscais que dela resultarão, tendo o prazo até ao último dia do mês seguinte do trimestre civil em que se tornou promotor; os utilizadores, a seu turno, devem divulgar na declaração do imposto do contribuinte (KORB, 2005, p. 64).

\section{Impactos da ação 12 do BEPS no Brasil}

No intuito de harmonizar o ordenamento jurídico brasileiro com as orientações do Plano BEPS, a Secretaria da Receita Federal editou a Medida Provisória no 685, em 21 de julho de 2015, a fim de instituir nova obrigação de prestação de informação, por parte do contribuinte (COELHO; CHIANG, 2018).

Heleno Torres (2015) destaca a importância da medida, que se baseia no dever de transparência e chega como parte do novo paradigma de "Fisco Global", em consistência com os esforços da OCDE e com o reforço da capacidade de fiscalização da Administração Tributária, mas com ganho notável na relação com os contribuintes, pela demanda de compliance e de boa fé que a medida impõe.

Nesse sentido, menciona-se o teor do artigo $7^{\circ}$ do referido diploma:

Art. $7^{\circ}$. O conjunto de operações realizadas no ano-calendário anterior que envolva atos ou negócios jurídicos que acarretem supressão, redução ou diferimento de tributo deverá ser declarado pelo sujeito passivo à Secretaria da Receita Federal do Brasil, até 30 de setembro de cada ano, quando:

I - os atos ou negócios jurídicos praticados não possuírem razões extratributárias relevantes;

II - a forma adotada não for usual, utilizar-se de negócio jurídico indireto ou contiver cláusula que desnature, ainda que parcialmente, os efeitos de um contrato típico; ou

III - tratar de atos ou negócios jurídicos específicos previstos em ato da Secretaria da Receita Federal do Brasil.

Parágrafo único. O sujeito passivo apresentará uma declaração para cada conjunto de operações executadas de forma interligada, nos termos da regulamentação.

Note-se que a obrigação de declarar operações que viessem a acarretar a supressão, a redução ou o diferimento de tributo, desde que os atos ou negócios jurídicos praticados não possuam razões extratributárias relevantes, ou a forma adotada não seja usual, que utilize-se de 
negócio jurídico indireto ou contenha cláusula que desnature, ainda que parcialmente, os efeitos de um contrato típico; ou, ainda, que trate de atos ou negócios jurídico específicos previsto em ato da Secretaria da Receita Federal do Brasil (CASTRO; RODRIGUES, 2015).

A Secretaria da Receita Federal do Brasil denominou a referida declaração de DIOR (Declaração de Informações de Operações Relevantes) mediante a edição do Ato Declaratório Executivo COFIS n ${ }^{\circ}$ 60/2015, introduzindo os Registros Y700, Y710 e Y720 na Escrituração Contábil Fiscal (ECF), pelos quais os sujeitos passivos cumpririam as determinações do artigo $7^{\circ}$ da MP 685/2015.

Ressalte-se que a motivação da OCDE para instituição do mandatory disclosure, não obstante serem bastante razoáveis, partem de pressupostos e estruturas que não são os mesmos existentes na realidade tributária brasileira, já que não há sequer uma regra geral antielisiva devidamente regulamentada no país (CASTRO; RODRIGUES, 2015).

Destarte, as estruturas do sistema jurídico-tributário dos países membros da OCDE são totalmente distintas do Sistema Tributário Nacional, pelo que qualquer "incorporação" de regras estrangeiras devem ser analisadas sob a ótica dos limites e direitos constitucionalmente previstos em nosso ordenamento. (CASTRO; RODRIGUES, 2015).

Insta salientar que a regulamentação dessa obrigação não foi mantida no momento da conversão da medida provisória em lei, especialmente graças às inúmeras críticas feitas no que tange à falta de compatibilidade com as normas constantes no Sistema Tributário Brasileiro.

Parte da doutrina aponta que o art. $9^{\circ}$ da MP $685 / 2015^{4}$, ao prever o não reconhecimento está, na verdade, desconsiderando o negócio jurídico, sem estabelecer o procedimento a ser utilizado para a desconsideração e, relembramos novamente, não há, no ordenamento jurídico pátrio, previsão de tal procedimento.

Heleno Torres (2015), a seu turno, tem opinião distinta, afirmando que a declaração e a consulta preventiva antielusiva não equivalem a alguma regulamentação do parágrafo único do art. 116 do CTN, nem correspondem a qualquer forma de "norma geral antielusiva":

\footnotetext{
${ }^{4}$ Art. $9^{\circ}$. Na hipótese de a Secretaria da Receita Federal do Brasil não reconhecer, para fins tributários, as operações declaradas nos termos do art. $7^{\circ}$, o sujeito passivo será intimado a recolher ou a parcelar, no prazo de trinta dias, os tributos devidos acrescidos apenas de juros de mora.

Parágrafo único. O disposto no caput não se aplica às operações que estejam sob procedimento de fiscalização quando da apresentação da declaração
} 
A norma não cria "procedimentos" mediante os quais a autoridade administrativa poderá desconsiderar atos ou negócios jurídicos praticados com a finalidade de dissimular a ocorrência do fato gerador do tributo ou a natureza dos elementos constitutivos da obrigação tributária. Portanto, sua função é diversa, ainda que se possa compreender como medida complementar para combater os planejamentos tributários agressivos ou abusivos.

Outrossim, o texto atribuiu um caráter de presunção de criminalização em transações que não necessariamente poderiam ser enquadradas como abusivas ou agressivas. A penalidade imposta pelo artigo 12 da MP 685/2015 traz uma presunção absoluta da autoridade administrativa, de que o contribuinte praticou ato doloso. Contudo, é vedada a edição de medida provisória para dispor acerca de matéria de direito penal, nos termos do art. $62, \S 1^{\mathrm{o}}, \mathrm{I}, \mathrm{b}$, da Constituição ${ }^{6}$ (CASTRO; RODRIGUES, 2015).

Diante das controvérsias atribuídas à referida medida, questionou-se se tal iniciativa legislativa não seria uma tentativa indireta de implementar regra "antielisiva" no Brasil, haja vista a falta de lei ordinária regulamentando o parágrafo único do art. 116 do Código Tributário Nacional, que permitiria a desconsideração, para fins tributários, de atos ou negócios jurídicos considerados abusivos (COELHO; CHIANG, 2018).

Outras críticas pertinentes em relação a esse diploma foram feitas por Henry Lummertz (2015), no sentido de que a medida provisória se afasta do Plano BEPS por não serem de fácil compreensão, com a utilização de termos imprecisos, possibilitando uma interpretação subjetiva por parte do Fisco.

Do mesmo modo, a MP considera suficiente, para o surgimento da obrigação de declarar as operações, a inexistência de "razões extratributárias relevantes", ao passo em que recomendação da OCDE é a de que as operações, para que devam ser obrigatoriamente declaradas, apresentem características distintivas (hallmarks), cuja presença indica a possível existência de um planejamento tributário que possa ser efetivamente qualificado como abusivo ou agressivo (LUMMERTZ, 2015).

\footnotetext{
${ }^{5}$ Art. 12. O descumprimento do disposto no art. $7^{\circ}$ ou a ocorrência de alguma das situações previstas no art. 11 caracteriza omissão dolosa do sujeito passivo com intuito de sonegação ou fraude e os tributos devidos serão cobrados acrescidos de juros de mora e da multa prevista no $\S 1^{\circ}$ do art. 44 da Lei $n^{\circ} 9.430$, de 27 de dezembro de 1996.

${ }^{6}$ Art. 62. Em caso de relevância e urgência, o Presidente da República poderá adotar medidas provisórias, com força de lei, devendo submetê-las de imediato ao Congresso Nacional.

$\S 1^{\circ}$ É vedada a edição de medidas provisórias sobre matéria:

I - relativa a: (...)

b) direito penal, processual penal e processual civil;"
} 
Finalmente, destaca-se que esta medida provisória foi objeto da Ação Declaratória de Inconstitucionalidade $\mathrm{n}^{\mathrm{o}} 5366$, em face de seus artigos $7^{\circ}, 8^{\circ}, 9^{\circ}, 10,11,12$ e 13 , cujo relator era o Ministro Luiz Fux. A referida ação foi julgada extinta sem julgamento do mérito, em decisão de 10 de dezembro de 2015, diante da não conversão em lei da medida provisória em questão.

\section{Considerações finais}

A globalização e a integração cada vez maior entre os países resultam na necessidade de um novo modelo de sistema tributário, especialmente no que concerna às atividades de fiscalização, que se realize de modo coerente com a complexidade dos negócios, com o crescente aumento da economia digital e com o fortalecimento da mútua assistência e trocas de informações.

Nesse ínterim, o Plano BEPS contribui fortemente para a coordenação global entre as administrações fiscais dos países, auxiliando na cooperação internacional entre eles, unidos com o propósito de salvaguardar o patrimônio público e sua capacidade de arrecadação de tributos.

Dentre as ações constantes do Plano BEPS, destacamos a de número 12, que prevê a regra do mandatory disclosure, impondo a transparência nas relações ente o Fisco e os contribuintes dos países, de modo que estes revelem seus esquemas de planejamento tributário agressivo. Inclusive, essa regra já existia desde o ano de 2008 em Portugal e já foi implementada em diversos países, como visto ao longo do presente trabalho.

No Brasil, é notório que a Receita Federal está empenhada em cumprir as ações propostas pela OCDE, como se nota através da edição de textos normativos e por sua intensa participação nas atividades dos grupos de trabalho da OCDE, cumprindo o compromisso de atender às demandas dos países parceiros do Fórum Global, o que demonstra um esforço do país para se tornar membro oficial da organização e harmonizar sua normatização com os preceitos internacionais.

No entanto, é importante salientar que todas as disposições internacionais devem passar por uma rigorosa análise de compatibilidade com a Constituição da República, diante da multiplicidade de direitos fundamentais e limitações ao poder de tributar existentes no ordenamento pátrio.

Isso porque, diante da complexidade do Sistema Tributário Nacional, é possível que venham a surgir uma impossibilidade de internalização de alguma das propostas constantes nas 
ações do BEPS. Esse foi o caso da primeira tentativa de introdução do Plano de Ação 12 (Mandatory Disclosure Rules) através da Medida Provisória 685/2015, a qual não foi convertida em lei.

A referida medida impunha aos contribuintes a obrigação acessória de informar, anualmente, à Receita Federal as operações e atos ou negócios jurídicos que acarretassem supressão, redução ou diferimento de tributo; igualmente, quando a declaração relatasse atos ou negócios jurídicos ainda não ocorridos, o contribuinte adotaria a consulta à legislação tributária.

Contudo, muitas críticas foram feitas a esses dispositivos, especialmente que a medida provisória estaria legislando de forma inconstitucional sobre crimes tributários, bem como que tratar-se-ia de regulamentação indevida da norma geral antielisiva que consta art. 116, parágrafo único, do CTN.

Concordamos, ainda, com os apontamentos da doutrina no sentido de que as regras constantes da medida não estão de acordo com a proposta da OCDE, principalmente pela falta de clareza em sua redação e pela utilização de termos vagos e imprecisos, o que prejudica a confiança do contribuinte na coerência da interpretação a ser utilizada pelo Fisco.

Ademais, não obstante as opiniões distintas, inexiste, no Brasil, regulamentação da norma geral antielisiva prevendo os procedimentos de desconsideração de um negócio jurídico em razão de um planejamento tributário agressivo, como existe nos países integrantes da OCDE.

Merece destaque ainda o fato de que não há qualquer definição doutrinária no Brasil, nem sequer no âmbito da OCDE, acerca do conceito de planejamento tributário agressivo, o que gera inúmeras controvérsias e viola a segurança jurídica, ao passo em que permite uma interpretação ampla por parte da Administração Tributária dos países.

Diante de todo o exposto, entendemos que a real intenção da Medida Provisória 685/2015 era o aumento da arrecadação e a imposição de uma fiscalização mais rigorosa, que não ocorreria de outro modo no cenário brasileiro e não estava adequada à necessidade de harmonização com as regras internacionais, em especial no contexto do Plano BEPS.

\section{Referências bibliográficas}

AMORIM, José Campos. Algumas Medidas de Combate à Evasão Fiscal. Revista de

Ciências Empresariais e Jurídicas, 12. Porto: Instituto Superior de Contabilidade e

Administração do Porto, 2007. 
AZEVEDO, Patrícia Anjos. O Princípio da Transparência: entraves e algumas manifestações e soluções práticas. TEIXEIRA, Glória (coord). Os dez anos de investigação do CIJE: estudos jurídico-económicos. Coimbra: Almedina, 2010.

BARRETO, Paulo Ayres. Ato Simulado e Sonegação Fiscal. In: CARVALHO, Paulo de Barros; SOUZA, Priscila de (Org.). Direito Tributário e os Conceitos de Direito Privado. São Paulo: Noeses, 2010. p. 1049-1066.

BORGES, Antônio de Moura. Noções de Direito Tributário Internacional. Revista Fórum de Direito Tributário - RFDT n. 26. Belo Horizonte: Fórum, 2007.

CANADÁ. Finances Québec. Fighting Aggressive Tax Planning. Information bulletin 2009-5. Disponível em: <http://www.finances.gouv.qc.ca/documents/bulletins/ en/BULEN_2009-5-a-b.pdf>. Acesso em 16 abr. 2018.

CARVAlHO, Paulo de Barros. Derivação e Positivação no Direito Tributário. v. 1. São Paulo: Noeses, 2011.

CASTRO, Diana Rodrigues Prado de; RODRIGUES, Thais Bandeira de Mello. A DIOR e o BEPS? A questionável compatibilidade da declaração com a ação 12 do Plano BEPS. Revista Eletrônica de Direito Tributário da ABDF, v. 5, p. 1, 2015. Disponível em: <http://abdf. com.br/index.php?option=com_content\&view=article\&id=2168>. Acesso em 16 abr. 2018.

COELHO, Renato; CHIANG, Gabriel O. Projeto BEPS no Brasil: Comentários sobre alterações legislativas e normativas brasileiras. Disponível em: $<$ https://www.jota.info/ opiniao-e-analise/colunas/coluna-do-stocche-forbes/projeto-beps-no-brasil-24012017>. Acesso em: 16 abr. 2018.

DOURADO, Ana Paula. Direito Fiscal: lições. Almedina: Coimbra, 2016. . Governação Fiscal Global. Almedina: Coimbra, 2017. 
HUCK, Hermes Marcelo. Evasão e elisão: Rotas Nacionais e Internacionais do

Planejamento Tributário. São Paulo: Saraiva, 1997.

KORB, Donald, L. Shelters, schemes, and abusive transactions: why today's thoughtful U.S. tax advisors should tell their clients to "just say no". Washington: Internal Revenue Service U.S. Department of the Treasury, 2005.

LOUREIRO, Carlos; NEVES, António Beja. Breve comentário ao recente regime de combate ao planeamento fiscal abusivo. Revista de finanças públicas e direito fiscal. $1, \mathrm{n} .^{\circ} 2$. Coimbra: Almedina, 2008.

\section{LUMMERTZ, Henry. MP 685 contraria diversas recomendações do Plano de Ação}

BEPS. Disponível em: <https://www.conjur.com.br/2015-set-01/henry-lummertz-mp-685contraria-recomendacoes-plano-acao-beps>. Acesso em 16 abr. 2018.

MARTINEZ, Antonio Lopo. Agressividade tributária: um survey da literatura. Revista de Educação e Pesquisa em Contabilidade. v. 11, Edição Especial, art. 6. Brasília: ABRACICON, 2017.

MELO, Luciana Grassano de Gouvêa; PIMENTEL, João Otávio Martins. O Plano de Ação BEPS e as mudanças de paradigmas na tributação. Revista Acadêmica da Faculdade de Direito do Recife. volume 88, número 2, jul./dez. 2016. Faculdade de Direito do Recife: Recife, 2016. Disponível em: <https://periodicos.ufpe.br/revistas/ACADEMICA/article/view/ 12099/15787>. Acesso em: 16 abr. 2018.

O’BRIEN, Cora. Are You Prepared for Mandatory Disclosure? Disponível em: $<$ http://www.cpaireland.ie/docs/default-source/media-and-publications/accountancyplus/taxation/are-you-prepared-for-mandatory-disclosure.pdf?sfvrsn=2>. Acesso em 16 abr. 2018.

ORGANIZAÇÃO PARA A COOPERAÇÃO E DESENVOLVIMENTO ECONÔMICO OCDE. Action Plan on Base Erosion and Profit Shifting. Paris: OECD Publishing, 2013. Disponível em: $<$ http://www.keepeek.com/Digital-Asset-Management/oecd/taxation/action- 
plan-on-base-erosion-and-profit-shifting_9789264202719-en\#.WmAtm6inHIU>. Acesso em 16 abr. 2018.

Plano de ação para o combate à erosão da base tributária e à transferência de lucros. Paris: OECD Publishing, 2014. Disponível em: http://dx.doi.org/10.1787/9789264207790-pt. Acesso em 16 abr. 2018.

Tackling aggressive tax planning through improved transparency and disclosure. Report on disclosure initiative. Disponível em: $<$ http://www.oecd.org/ tax/exchange-of-tax-information/48322860.pdf>. Acesso em 16 abr. 2018.

OLIVEIRA, Maria Odete. Algumas reflexões sobre as questões de fiscalidade conexas com a erosão das bases tributáveis e transferência de lucros. REIS, João (Coord.). Para Jorge Leite - Escritos Jurídicos, Vol. II. Coimbra: Coimbra Editora, 2015.

REINO UNIDO. HM Revenue \& Customs. Disclosure of tax avoidance schemes: income tax, corporation tax, capital gains tax, national insurance contributions, stamp duty land tax, annual tax on enveloped dwelling and inheritance tax. Dotas Guidance. 2013.

Disponível em: <https://assets.publishing.service.gov.uk/government/uploads/system/uploads/ attachment_data/file/701190/DOTAS-March.pdf>. Acesso em 18 abr. 2018.

TEIXEIRA, Glória. Manual de Direito Fiscal. 2 ed. Coimbra: Almedina, 2010.

TORRES, Ricardo Lobo. Planejamento tributário: elisão abusiva e evasão fiscal. Rio de Janeiro: Elsevier, 2012.

TÔRRES, Heleno Taveira. Direito tributário internacional: planejamento tributário e operações transnacionais. São Paulo: Revista dos Tribunais, 2001.

. O planejamento tributário abusivo é o novo alvo do Fisco Global. 2015. Disponível em: <https:/www.conjur.com.br/2015-jul-26/heleno-torres-planejamento-tributario-abusivoalvo-fisco-global>. Acesso em 16 abr. 2018. 
VALADÃO, Marcos Aurélio Pereira; CAPONE, Rodrigo Senne. Planejamento tributário internacional: double irish arrangement. MURTA, Antônio Carlos Diniz (Org.). DIREITO TRIBUTÁRIO: XXIII ENCONTRO NACIONAL DO CONPEDI. 1ed. v. 1. Florianópolis: CONPEDI, 2014. p. 266-285.

VIEIRA, Laureana Rita Pires. Planeamento Fiscal Abusivo: Exemplificação de Alguns Esquemas. 2014. Dissertação (Mestrado em Contabilidade e Finanças). Instituto Superior de Contabilidade e Administração do Porto, Instituto Politécnico do Porto, Porto.

UNIÃO EUROPEIA. Jornal Oficial da União Europeia. Recomendação da Comissão de 6 de dezembro de 2012 relativa ao planeamento fiscal agressivo (2012/772/UE). Disponível em: <https://eur-lex.europa.eu/legal-content/PT/TXT/PDF/?uri=CELEX:32012H0772\&from= PT>. Acesso em: 16 abr. 2018. 


\title{
EXCLUSÃO DO ICMS DA BASE DE CÁLCULO DO PIS E DA COFINS: O SUPREMO TRIBUNAL FEDERAL DEVE MODULAR OS EFEITOS?
}

\author{
Maria de Fátima Ribeiro \\ Unimar \\ Lucas Pires Maciel \\ Unimar
}

\begin{abstract}
Resumo
O presente artigo tem como mote analisar os aspectos do julgamento do Recurso Extraordinário $\mathrm{n}^{\circ} 574.706$ que se refere à exclusão do ICMS da base de cálculo do PIS e da COFINS. Esse caso foi apreciado em idos de 2017 pela Suprema Corte brasileira e definiu tese favorável aos contribuintes. Ocorre que, a Procuradoria da Fazenda Nacional realizou recurso para que o Supremo Tribunal Federal faça a modulação dos efeitos, tendo em vista um provável desequilíbrio nas contas públicas. O objeto é analisar sobre a modulação os efeitos. Foi utilizado o método dedutivo, com pesquisas bibliográficas e análise de jurisprudências.
\end{abstract}

Palavras-Chave: Controle de Constitucionalidade, Direito Tributário, Modulação dos efeitos.

\begin{abstract}
Resumen/Résumé
This article has objective to analyze aspects of the judgment of Extraordinary Appeal $n^{0} 574.706$ that refers to the exclusion of ICMS from the calculation basis of PIS and COFINS. This case was appraised in the 2017 by Brazilian Supreme Court and defined thesis favorable to the taxpayers. It occurs that, the Attorney of the National Treasury has filed an appeal to the Federal Supreme Court effect the modulation of the effects, in view of probable imbalance in public accounts. Thus, the object is to analyze the modulation of the effects. The deductive method was used, with bibliographical and jurisprudence.
\end{abstract}

Keywords/Palabras-claves/Mots-clés: Constitutional control, Taxation law, Modulation of the effects. 


\section{Introdução}

O STF - Supremo Tribunal Federal, como corte constitucional do Brasil, exerce papel de grande importância, na manutenção da supremacia da Constituição Federal, ao realizar o controle de constitucionalidade das leis e atos normativos, seja por ação ou omissão legislativa.

Esse controle realizado pelo STF pode ser feito pelo controle difuso, dentro dos casos concretos, em qualquer lide levada ao conhecimento do Poder Judiciário, ou pelo controle concentrado, por intermédio dos remédios constitucionais colocados à disposição de alguns legitimados, estrategicamente elencados pela Constituição Federal, para criação de uma cláusula de barreira para as medidas legislativas prejudiciais ao sistema constitucional.

Esses controles tem grande valia para a mantença do Estado Democrático de Direito, tendo em vista que uma lei editada ao arrepio da Constituição Federal pode ser uma grave ameaça a toda estrutura constitucional do país.

No controle de constitucionalidade, cabe ao órgão julgador, em especial, ao Supremo Tribunal Federal, avaliar os efeitos em que essa declaração de (in)constitucionalidade ocorrerá. Regra geral esse efeito é o erga omnes e ex tunc, uma vez que o ato normativo sendo declarado inconstitucional, declara-se a sua nulidade desde a sua edição.

Ocorre que, os efeitos acima expostos são a regra do sistema, sendo que é possível, em algumas situações, alterar essa lógica e modificar os efeitos, modulando-os para atender à segurança jurídica e ao interesse social, como prevê o artigo 27, da Lei nº 9.868/1999.

Essa excepcionalidade dos efeitos também pode ser observada no campo das lides tributárias, em que a Suprema Corte brasileira pode, observando a necessidade, regular os efeitos de uma lei ou ato normativo tributário, para que seus efeitos se amoldem melhor, para evitar, com isso, problemas mais graves à segurança jurídica ou ao interesse público.

Assim, cabe ao Supremo Tribunal Federal analisar nos casos a serem analisados se o efeito será ex tunc, ex nunc, ou até mesmo para o futuro

Contudo, essa análise não é uma missão fácil, especialmente no que toca às matérias tributárias, haja vista que as questões tributárias representam papel importante na estrutura do país.

Um dos casos que chama a atenção na seara tributária é o Recurso Extraordinário $\mathrm{n}^{\circ}$ 574.706, que discute a tese da exclusão do ICMS - Imposto sobre Circulação de Mercadorias e sobre Prestações de Serviços de Transporte Interestadual, Intermunicipal e de Comunicação, da base de cálculo do PIS - Programa de Integração Social e da COFINS - Contribuição para o 
Financiamento da Seguridade Social. É um caso de suma importância para a práxis jurídica, para todo o meio dos aplicadores do Direito, para o orçamento da União e para a economia das empresas.

O Supremo Tribunal Federal, em idos de 2017, julgou a inconstitucionalidade da inclusão do ICMS na base de cálculo do PIS e da COFINS. É uma tese que já tem muitos anos em discussão no Poder Judiciário.

A Procuradoria da Fazenda Nacional, assim que publicado o acórdão, interpôs Embargos de Declaração, objetivando a modulação dos efeitos, para que o Supremo não aplique a regra geral, qual seja, o efeito ex tunc.

Assim, há uma discussão jurídica perante o órgão máximo do Judiciário nacional, para definir os efeitos dessa decisão importante para as atividades econômicas locais.

Para a confecção do presente artigo, necessário analisar o instituto da modulação dos efeitos, elucidando sobre o seu uso, requisites e bases de aplicação. Ademais, realizar um estudo acerca do caso em espeque, apresentando os pontos fulcrais desse julgado e traçar um paralelo entre os argumentos da Procuradoria e das empresas, para demonstrar, ao final, uma perspectiva de como deve agir o Supremo Tribunal Federal nesse caso.

Para tanto, utilizar-se-á o método dedutivo, tendo como foco a doutrina e a legislação que envolvam o tema, além da análise jurisprudencial.

\section{Modulação dos efeitos em sede de controle de constitucionalidade}

A Constituição é o documento jurídico mais importante de um povo e de uma nação. É uma lei fundamental, que tem como fito apresentar os principais elementos de organização, manutenção e desenvolvimento de um Estado.

Por esse motivo, é uma carta política de suma importância para que o Estado Democrático de Direito seja preservado. Assim, para evitar quebra nessa estrutura, os atos infraconstitucionais elaborados contra a Constituição Federal deverão ser afastados, sob pena de vilipêndio ao sistema constitucional.

Para isso, tem-se os mecanismos de controle de constitucionalidade. Walter Claudius Rothenburg (2010, p. 95) assevera acerca do controle de constitucionalidade "serve para invalidar atos jurídicos ou alguns de seus efeitos, quando incompatíveis com a Constituição. Mas serve também para conformar atos jurídicos, quando houver possibilidade de compatibilizá-los, como ocorre com a técnica da interpretação conforme a Constituição". 
Assim, o controle de constitucionalidade não tem o jaez apenas de proteger a Constituição, mas o de forçar o cumprimento dela.

Não se pode perder de vista que, além do mais, o controle de constitucionalidade tem como designo afastar eventuais abusos de poder, que sabidamente podem ocorrer.

Nessa linha de pensamento, Dirley da Cunha Júnior (2016, p. 34) conceitua controle de constitucionalidade, como sendo "garantia da tutela da supremacia da Constituição, é uma atividade de fiscalização da validade e conformidade das leis e atos do Poder Público à vista de uma constituição rígida, desenvolvida por um ou vários órgãos constitucionalmente designados".

É cediço que no controle de constitucionalidade brasileiro existe o controle pelas próprias casas legislativas, dentro de uma análise dos projetos legislativos, além dos controles judiciais, por meio do controle difuso ou concentrado.

O controle difuso é realizo em qualquer caso concreto levado ao conhecimento do Poder Judiciário, que poderá declarar a inconstitucionalidade de forma incidental. Por esse motivo, em regra, os efeitos da declaração de inconstitucionalidade serão ex tunc e inter partis. Há, contudo, atualmente, várias formas de modificação dos efeitos desse controle, em especial, pela existência de súmulas de efeito vinculante pelo Supremo Tribunal Federal, os recursos repetitivos dos tribunais superiores e um fortalecimento dos precedentes jurisprudenciais.

Ademais, há o controle concentrado, decorrente do direito austríaco distingue-se do americano, precipuamente, em três pontos. Nos ensinamentos de Dirley da Cunha Júnior (2016, p. 74):

\footnotetext{
O sistema austríaco-kelsiano do controle "concentrado" de constitucionalidade difere fundamentalmente, como já afirmamos, do sistema americano do controle "difuso", em diversos pontos: a) quer sob o ponto de vista "subjetivo", ou seja, do órgão que exerce o controle; b) quer sob o ponto de vista "modal", isto é, do modo ou da forma como o controle é exercido e a questão da constitucionalidade é resolvida; c) quer, finalmente, sob o ponto de vista "funcional", vale dizer, respeitante aos efeitos que a decisão produz seja em relação à lei submetida ao controle, seja em relação ao caso no qual a questão de constitucionalidade tenha sido suscitada.
}

Por essa nova roupagem no controle de constitucionalidade, introduzida no início do século XX, muitos países passaram a adotá-lo. O Brasil foi um dos países que incorporou esse controle de constitucionalidade, denominando o STF para exercer esse papel de Tribunal Constitucional, para afastar atos normativos federais ou estaduais que firam a Constituição 
Federal. Os Tribunais de Justiça dos Estados e do Distrito Federal, por sua vez, fazem o controle dos atos normativos estaduais e municipais violadores da Constituição Estadual.

Esse controle é exercido por legitimados eleitos pela Constituição Federal e podem discutir a constitucionalidade in abstracto. Como efeito desse controle, tem-se a regra de ser ex tunc e erga omnes.

Para exercício da atribuição concedida ao Supremo Tribunal Federal, existem as seguintes ações dentro do controle concentrado: a) ação direta de inconstitucionalidade por ação (ADI); b) ação direta de inconstitucionalidade por omissão (ADI por omissão); c) ação direta de inconstitucionalidade interventiva; d) ação declaratória de constitucionalidade (ADC); e) arguição de descumprimento de preceito fundamental (ADPF).

A Lei $\mathrm{n}^{\circ}$ 9.868, de 10 de novembro de 1999, dispõe sobre o processo e julgamento da ação direta de inconstitucionalidade e da ação declaratória de constitucionalidade perante o Supremo Tribunal Federal.

Essa lei indica todo o procedimento das citadas ações perante o STF. A lei autoriza que seja concedida cautelar para já de plano interromper a aplicação da lei ou do ato normativo impugnado. Se for período de recesso da Corte, poderá o relator decidir monocraticamente acerca do caso.

Já a Lei $\mathrm{n}^{\circ}$ 9.882, de 03 de dezembro de 1999, dispõe sobre o processo e julgamento da arguição de descumprimento de preceito fundamental, nos termos do § 1o do art. 102 da Constituição Federal.

Ocorre que, quando da análise dos efeitos, é possível realizar limitações, especialmente por alusão à primazia da segurança jurídica ou até com base no interesse social.

Como forma de aplicação desses princípios, a própria legislação já se incumbiu de criar regra acerca do tema. O artigo 27, da Lei $n^{\circ}$ 9.868/99, atribui competência ao STF para "restringir os efeitos daquela declaração ou decidir que ela só tenha eficácia a partir de seu trânsito em julgado ou de outro momento que venha a ser fixado", bastando decisão por maioria de dois terços dos ministros.

É sempre interessante analisar, numa lei, a sua exposição de motivos que acompanhou o projeto de lei. Nesse caso, ficou exposto que deverá existir um "juízo rigoroso de ponderação entre o princípio da nulidade da lei inconstitucional, de um lado, e os postulados da segurança jurídica e do interesse social, de outro (art. 27)"”.

No mesmo sentido, prossegue asseverando que “o princípio da nulidade somente será afastado in concreto se a juízo do próprio Tribunal, se puder afirmar que a declaração de nulidade acabaria por distanciar-se ainda mais da vontade constitucional”. 
A modulação de efeitos possibilita que o Supremo faça uma análise de cada caso individualmente, verificando quais as reais consequências de utilização do efeito ex tunc (AGRA, 2008, p. 65).

Lourival José de Oliveira e Walkiria Martinez Heinrich Ferrer afirmam que a "principal justificativa apresentada para impor de forma expressa a modulação de efeitos pelo STF é a insegurança jurídica, de forma a afastar os efeitos produzidos pela declaração de nulidade de norma inconstitucional"1.

Pela sua importância e complexidade, a modulação deve ser vista com ares restritivos, devendo ser aplicado com parcimônia e obedecendo algumas limitantes. Emília Maria Velano (2011, p. 22) assevera que a aplicação desse dispositivo legal deve ser de caráter excepcional, uma vez que "situações jurídicas declaradas inconstitucionais pelo próprio Supremo Tribunal Federal poderão se consolidar”.

Desta feita, a modulação dos efeitos deve ser observada pelo Supremo sempre e quando necessário, para não ser utilizado como de forma errônea e causar distorções no sistema.

Isso ganha uma maior complexidade quando se trata de atos normativos tributários elaborados ao arrepio da Constituição Federal.

Tal constatação se faz, pois o tributo tem papel de destaque no contexto atual, haja vista a crise financeira/administrativa que vem passando os entes políticos nacionais, além do papel extrafiscal que exerce o tributo. Portanto, um tributo instituído pelo veículo errado, ao invés de lei complementar por lei ordinária, taxado com alíquotas acima do que permitido, se não obedeceu aos princípios constitucionais tributários, tudo isso pode gerar algum comprometimento na vida de um ou vários contribuintes, que pagaram o tributo.

E mais, o recurso advindo do tributo indevidamente instituído e cobrado pelo ente político foram utilizados para consecução dos objetivos da Administração Pública. Assim, sempre que se tratar de uma disputa judicial na seara tributária, é comum o envolvimento de valores financeiros. Por isso, a modulação dos efeitos ganha contornos mais complexos de solução.

Na questão tributária, a regra é pela devolução por parte do ente federado dos tributos indevidamente arrecadados com a lei inconstitucional. Contudo, ocorrerão situações concretas

\footnotetext{
${ }^{1}$ OLIVEIRA, Lourival José; FERRER, Walkiria Martinez Heinrich. Da inconstitucionalidade da denúncia feita à convenção $\mathrm{n}^{\circ} 158$ da OIT: impossibilidade de limitação de seus efeitos frente à violação de direito social. Revista Argumentum, v. 18, n. 1, jan./abr. 2017, p. 125-146. Disponível em: <http://ojs.unimar.br/index.php/ revistaargumentum/article/view/340/90>. Acesso em 20 jan. 2018, p. 137.
} 
em que o Supremo irá definir a não retroação dos atos e, nesse caso, poder-se-á modular os efeitos temporais dessa inconstitucionalidade.

A questão tributária torna-se tão intrincada para aplicação cartesiana da modulação dos efeitos, uma vez que envolve matéria, condizente ao patrimônio do contribuinte, uma matéria que tem a legalidade cerrada, dentro de regras específicas e segundo o STF, é racional que quando houver uma questão tributária, no que toca às questões de direito, envolve repercussão geral, haja vista o impacto de uma decisão para um sem número de outras pessoas.

De tudo que foi exposto, é de grande valia que o Supremo analise com parcimônia cada caso tributário levado a julgamento pelo controle difuso ou concentrado, no que toca à modulação dos efeitos.

\section{A exclusão do ICMS da base de cálculo do PIS e da COFINS}

Nesse momento, está em discussão perante o STF, a modulação ou não dos efeitos no $\mathrm{RE}^{\circ}$ 574.706, que discute a tese da exclusão do ICMS da base de cálculo do PIS e da COFINS. É um caso de suma importância para a práxis jurídica, para todo o meio dos aplicadores do Direito, para o orçamento da União e para a economia das empresas.

Não é uma tese de discussão recente, mas que teve muitos desdobramentos durante os anos. O grande embate entre União e contribuintes é se o ICMS poderia ou não compor a base de cálculo das contribuições do PIS e da COFINS.

As Súmulas 68 e 94 do STJ - Superior Tribunal de Justiça consolidaram o entendimento deste tribunal e também do extinto TFR - Tribunal Federal de Recursos, que aduzia que "inclui-se na base de cálculo do PIS e parcela relativa ao ICM" (Súmula 258), bem como, por analogia, inclui-se na base de cálculo do Finsocial o valor relativo ao ICM (antes dessa nova figura que se tem hoje do ICMS).

No Supremo Tribunal Federal essa questão já foi decidida, em controle difuso, em outro recurso, qual seja, o RE $n^{\circ} 240.785 / \mathrm{MG}$. No caso apresentado, foi dado provimento ao recurso do contribuinte para declarar que o ICMS não se enquadra no conceito de faturamento, sendo, portanto, não devida a sua inclusão na base de cálculo do PIS e da COFINS.

Esse caso, em idos de 1999, o Plenário do STF iniciou o julgamento, no qual se discute a constitucionalidade da inclusão do ICMS na base de cálculo da COFINS, conforme Informativo do STF $\mathrm{n}^{\circ} 161$. 
Na sessão plenária de 22.3.2006, o Tribunal, por unanimidade, deliberou a renovação de julgamento, a sustentação oral e o retorno dos autos ao Ministro-Relator, nos termos do Informativo $n^{\circ} 437$.

Em 24 de agosto de 2006, reiniciado o julgamento do recurso extraordinário, o Ministro Marco Aurélio votou no sentido de dar provimento ao recurso extraordinário, no que foi acompanhado pelos Ministros Ricardo Lewandowski, Carlos Britto, Cezar Peluso, Sepúlveda Pertence e também o Ministro Marco Aurélio, relator. Na ocasião, o Ministro Eros Grau divergiu dessa orientação, e o Ministro Gilmar Mendes pediu vista dos autos, presente no já mencionado Informativo $n^{\circ} 437$.

Como já exposto acima, o julgamento dessa questão ocorreu apenas em 08 de outubro de 2014, com maioria dos votos do Plenário, vencidos os Ministros Eros Roberto Grau e Gilmar Ferreira Mendes, acolheu de forma parcial do Recurso Extraordinário do contribuinte para determinar a inconstitucionalidade da inclusão do valor do ICMS, destacado em nota fiscal, na base de cálculo da COFINS (Informativo $n^{\circ} 762$ ). O voto vencedor do Ministro Marco Aurélio foi acompanhado pelos Ministros Cármen Lúcia, Ricardo Lewandowski, Carlos Ayres Britto, Cezar Peluso, Sepúlveda Pertence e Celso de Mello.

O trânsito em julgado desse acórdão deu-se em 23 de fevereiro de 2015 e teve validade apenas entre as partes, uma vez que quando do início do julgamento desse caso não havia a Emenda Constitucional $n^{\circ} 45 / 2004$, que criou a repercussão geral e, por esse motivo, o julgamento ocorreu sem se atribuir esse efeito. A despeito disso, toda a discussão foi muito produtiva e auxiliou quando do julgamento do RE $\mathrm{n}^{\mathrm{o}} 574.706$.

Em idos de outubro de 2007, o então Presidente da República, Luiz Inácio Lula da Silva e o Advogado-Geral da União, à época, José Antônio Dias Tóffoli, ajuizaram uma ADC - Ação Declaratória de Constitucionalidade, $\mathrm{n}^{\mathrm{o}}$ 18, objetivando a declaração de constitucionalidade do artigo $3^{\circ}, \S 2^{\circ}$, inciso I, da Lei $\mathrm{n}^{\circ}$ 9.718, de 27 de novembro de 1998 . Essa ação nasceu quando o governo federal observou o exacerbado número de demandas judiciais que se espalharam pelo país, dos contribuintes que queriam ver afastada a inclusão do ICMS da base de cálculo do PIS e da COFINS.

Assim, a ação foi proposta para tentar frear essas ações, que muitas vezes tinham o crivo positivo dos juízes de primeiro grau, com a concessão de liminares e tutelas provisórias, o que já assustava o governo federal em relação à perda de arrecadação.

A Ministra Relatora Cármen Lúcia, juntamente com os Ministros Marco Aurélio, Menezes Direito, Ricardo Lewandowski, Eros Grau, Joaquim Barbosa, Ayres Britto, Cezar Peluso e Celso de Mello acolheram a repercussão geral em 24/04/2008, conforme ementa: 
Reconhecida a repercussão geral da questão constitucional relativa à inclusão do ICMS na base de cálculo da COFINS e da contribuição ao PIS. Pendência de julgamento no Plenário do Supremo Tribunal Federal do Recurso Extraordinário n. 240.785. (RE 574706 RG, Relator(a): Min. CÁRMEN LÚCIA, julgado em 24/04/2008, DJe-088 DIVULG 15-05-2008 PUBLIC 16-05-2008 EMENT VOL02319-10 PP-02174 )

Nesse sentido foi gerado o Tema 69 de repercussão geral, que tem a redação: "Inclusão do ICMS na base de cálculo do PIS e da COFINS".

Em 13 de agosto de 2008 foi proferida decisão

\begin{abstract}
Ocorre que, enquanto não encerrado o julgamento pelo Plenário do Supremo Tribunal Federal do Recurso Extraordinário $\mathrm{n}^{\mathrm{o}}$ 240.785/MG, a jurisprudência permanece sujeita a flutuações inconvenientes aos sujeitos passivos da obrigação tributária e ao próprio Estado, recomendando a paralisação das demandas em trâmite, relativas ao tema destes autos. [...]

Anote-se, ainda, que o controle direto de constitucionalidade precede o controle difuso, não obstando o ajuizamento da ação direta o curso do julgamento do recurso extraordinário.

Com essas razões, assinalando a relevância da matéria, nos termos do artigo 21 da lei 9.868, de 10/11/99, defiro a medida cautelar para determinar que os Juízes e Tribunais suspendam o julgamento dos processos em trâmite, aí não incluídos, evidentemente, os processos em andamento nesta Corte, que envolvam a aplicação do art. $3^{\circ}, \S 2^{\circ}$, inciso I, da Lei 9.718, de 27/11/98.
\end{abstract}

A maioria dos Ministros acolheu o pedido, sendo os Ministros Marco Aurélio e Celso de Mello, voto vencido, uma vez que indeferiam a medida cautelar. Desta forma, foram informados todos os juízos, tribunais de todas as instâncias, para que todos os processos que discutissem essa tesa fossem suspensos para aguardar a deliberação do Pretório Excelso.

Essa manobra do governo federal garantiu um certo alívio momentâneo, arrefecendo as questões em embate.

A suspensão deferida foi de 180 dias, porém em outras três oportunidades os Ministros prorrogaram a medida. Ainda não houve julgamento dessa ação.

Contudo, após essa última prorrogação, não houve nova suspensão e, em idos de 2011, as ações por todo o país voltaram a tramitar.

Assim, várias demandas judiciais tiveram julgamento pelo país. Ocorre que, um fato novo alterou essa questão: em 15 de março de 2017, o Supremo Tribunal Federal, com o mecanismo da repercussão geral ( $n^{\circ} 69$, acima indicada), por maioria dos votos, definiu que a 
União não pode incluir o ICMS na base de cálculo das contribuições para o PIS e para a COFINS.

Acompanharam a relatora Ministra Cármen Lúcia, além do Ministro Celso de Mello, os Ministros Marco Aurélio Mello, Luiz Fux, Rosa Weber e Ricardo Lewandowski. Por outro lado, além do Ministro Gilmar Mendes, votaram contra a exclusão do ICMS da base de cálculo e foram derrotados no julgamento os Ministros Edson Fachin, Luís Roberto Barroso e Dias Tóffoli.

Na ocasião do julgamento, que teve início em 09 de março de 2017, a Ministra Cármen Lúcia, assentando as mesmas bases do Recurso Extraordinário no 240.78 , definiu que o ICMS não pode ser incluído na base de cálculo do PIS e da COFINS. Acompanharam o voto da relatora, os Ministros Rosa Weber, Luiz Fux, Ricardo Lewandowski e Marco Aurélio.

Nesse ínterim, o Ministro Edson Fachin abriu a divergência e negou provimento ao recurso interposto pelo contribuinte. A divergência foi acompanhada pelos Ministros Luís Roberto Barroso e Dias Tóffoli. Depois disso, o julgamento foi suspenso, nos termos Informativo $\mathrm{n}^{\circ} 857$.

O julgamento foi retomado em 15 de março de 2017, com o voto de acordo com a Relatora do Ministro Celso de Mello e o com o voto divergente do Ministro Gilmar Ferreira Mendes. Um ponto interessante nesse dia de julgamento foi que a Ministra Relatora Cármen Lúcia informou que com relação à modulação dos efeitos deveriam ser feitos pedidos por meio de embargos de declaração, haja vista a inexistência de pedido expresso, conforme Informativo $\mathrm{n}^{\mathrm{o}} 856$.

O acórdão foi publicado no dia 02 de outubro de 2017. Por esse motivo, a repercussão geral $n^{\text {o }} 69$, ficou com a seguinte redação: “O ICMS não compõe a base de cálculo para a incidência do PIS e da COFINS".

Esse acórdão, diferentemente do que ocorreu no julgamento do $\operatorname{RE~} \mathrm{n}^{\mathrm{o}} 240.785$, tem eficácia erga omnes. Assim, valerá para todos os processos em julgamento pelo país inteiro e que tenha essa mesma temática, ocasião em que deverão os respectivos julgadores aplicar o entendimento definido pelo Supremo, uma vez que possui força vinculante.

Antes de avançar em outros pontos importantes, é salutar ponderar que houve uma relevante mudança no status dessa discussão, tendo em vista uma mudança legislativa peculiar.

A Lei $n^{\circ} 12.973$, de 13 de maio de 2014, editada após a criação da Medida Provisória $\mathrm{n}^{\mathrm{o}} 627$, de 11 de novembro de 2013, a despeito dessa discussão judicial perante o Supremo, alterou o artigo 12, do Decreto-lei, para expor que no regime cumulativo a base de cálculo das 
contribuições sociais PIS e COFINS não é mais o faturamento e sim a receita bruta, o que englobaria, de certa forma, o que se paga a título de ICMS.

Para Vagner Cristiano Modesto (2017, p. 167-168), essas alterações legislativas concederam status de legalidade para a inclusão do ICMS na base de cálculo do PIS e da COFINS, "contrariando posicionamento do STF que declarou que o tema é matéria de competência constitucional".

Por essa razão, essa decisão do Supremo, decidida em 2017, não tem aplicabilidade para essa novel legislação e, por isso, caso os contribuintes não concordem com essa ampliação feita, terão que mover novas demandas judiciais ou, então, os legitimados para as ações do controle concentrado.

\section{A modulação dos efeitos no julgamento do recurso extraordinário no 574.706}

Com a posição final dada pela Ministra relatora, ainda em outubro de 2017, mês da publicação do acórdão, o Procurador da Fazenda Nacional Carlos de Araújo Moreira, como se vê do andamento do processo, disponibilizado no sítio do STF, interpôs recurso de embargos de declaração, que ainda pendem de julgamento, especificamente para que seja realizada a modulação dos efeitos e outros pontos, que segundo o Procurador o acórdão foi omisso ou contraditório. Sem dúvida, a parte fulcral de análise, em decorrência do objeto deste trabalho.

$\mathrm{Na}$ referida petição a União, que se sustenta "dado seu inequívoco impacto e abrangência, só deve produzir efeitos gerais, após o julgamento dos presentes Embargos de Declaração e da definição de todas as questões pendentes, supra expostas",2, aduz que a decisão proferida nesse caso poderá impactar drasticamente o sistema tributário, uma vez que essa mesma tese valerá para outros tributos, citando uma notícia do Valor Econômico de 17 de março de 2017, intitulada de "Tributaristas preveem onda de contestações"3.

Na notícia indicou-se que, a decisão, nos termos em que foi proferida, uma vez que atingirá grandemente o sistema tributário brasileiro, podendo alcançar um sem número de tributos; provocará uma mudança nos preços relativos da economia, "beneficiando os maiores contribuintes do ICMS"; imporá uma reforma tributária, sem garantias de ser um sistema

\footnotetext{
${ }^{2}$ Disponível em: <https://www.conjur.com.br/dl/embargos-pgfn-icms-pis-cofins.pdf>. Acesso em: 02. jan.2018.

3 Tributaristas preveem onda de contestações. Embora ainda estejam aguardando a publicação do acórdão do Supremo Tribunal Federal (STF), contrária à inclusão do Imposto sobre Circulação de Mercadorias e Serviços (ICMS) na base de cálculo do PIS e da Cofins, os especialistas em tributação consultados pelo Valor não têm dúvida: a decisão de quarta-feira abriu uma enorme controvérsia jurídica. "A mesma tese será usada para questionar outros tributos", prevê o ex-secretário da Receita Federal, Everardo Maciel. "Ela atinge todo o sistema tributário brasileiro", acrescentou. Disponível em: <http://www.valor.com.br/brasil/4902732/tributaristaspreveem-onda-de-contestacoes $>$.Acesso em: 07 maio 2018.
} 
melhor; e a possibilidade de restituições que implicarão em vultosas transferências de riqueza dentro da sociedade ${ }^{4}$.

Posteriormente trata sobre o impacto financeiro e orçamentário para a União em decorrência dessa demanda, afirmando que "chegou aos seguintes valores, com base em informações da Receita Federal do Brasil, para as possíveis restituições: R \$ 250.294,05 milhões [mais de 250 bilhões], até 2015. Tais números, no que tange às perdas, se repetiram na LDO Lei de Diretrizes Orçamentárias de 2017"\%.

Contudo o próprio Procurador informa da dificuldade de estimar concretamente tais valores, haja vista a interferência de vários fatores no computo desses tributos.

Várias notícias repercutiram acerca desse valor indicado pelo Procurador, dando ensejo ao tamanho de uma decisão como essa do Supremo ${ }^{678}$.

Além do mais, a jornalista Beatriz Olivon, do Valor Econômico, enuncia que a União perderá vinte bilhões de reais por ano com essa decisão do Supremo, além dos duzentos e cinquenta bilhões já indicados para o passado, levando em consideração o intervalo entre 2003 e $2014^{9}$. No mesmo sentido foram as notícias destacadas ${ }^{1011}$.

Contudo, Eduardo Salusse, em 09 de outubro de 2017, escreveu uma matéria intitulada "STF sugere que irá modular efeitos da exclusão do ICMS do PIS/COFINS [sic]", e faz alerta importante acerca das colocações do Procurador, aduzindo que:

Se o STF mantiver coerência e não se deixar enganar pelas já desmentidas e superdimensionadas previsões de impacto orçamentário, deve atribuir efeitos prospectivos ao julgamento e preservar as ações judiciais em andamento, tendo como base a data do julgamento ${ }^{12}$.

\footnotetext{
${ }^{4}$ Disponível em: <https://www.conjur.com.br/dl/embargos-pgfn-icms-pis-cofins.pdf $>$. Acesso em: 02 maio 2018.

${ }^{5}$ Disponível em: <https://www.conjur.com.br/dl/embargos-pgfn-icms-pis-cofins.pdf>. Acesso em 02 maio 2018.

${ }^{6}$ Disponível em: <http://www.migalhas.com.br/dePeso/16,MI209242,31047-

Expectativas + sobre+a+exclusao+do+ICMS+da+base+de+calculo+do+PIS+e+da $>$. Acesso em: 07 maio 2018.

7 Disponível em: <http://politica.estadao.com.br/blogs/fausto-macedo/os-250-bilhoes-e-o-dilema-do-supremotribunal-federal/>. Acesso em: 07 maio 2018.

8 Disponível em: <https://oglobo.globo.com/economia/decisao-do-stf-sobre-base-de-calculo-do-piscofinsreduzira-em-27-bilhoes-arrecadacao-federal-21067057>. Acesso em: 07 maio 2018.

${ }^{9}$ OLIVON, Beatriz. União perderá $R \$ 20$ bi por ano com decisão do STF sobre cálculo da Cofins. Disponível em: <http://www.valor.com.br/legislacao/4901162/uniao-perdera-r-20-bi-por-ano-com-decisao-do-stf-sobrecalculo-da-cofins $>$. Acesso em: 07 maio 2018.

${ }^{10}$ Disponível em:

$<$ http://www.stf.jus.br/portal/cms/verNoticiaDetalhe.asp?idConteudo=337926\&caixaBusca=N $>$. Acesso em: 07 maio 2018.

${ }^{11}$ Disponível em: <http://www.migalhas.com.br/Quentes/17,MI267432,71043STF+publica+acordao+que+ exclui+ICMS+da+base+de+calculo+do+PISCofins $>$. Acesso em: 07 jan. 2018.

12 SALUSSE, Eduardo. STF sugere que irá modular efeitos da exclusão do ICMS do PIS/Cofins. Disponível em: $<$ http://www.valor.com.br/legislacao/fio-da-meada/5146688/perspectivas-na-exclusao-do-icms-da-base-decalculo-do-pis-e-da-cofi>. Acesso em: 02 maio 2018.
} 
Veja que o autor orienta para uma supervalorização dos prejuízos da União com a demanda e, com isso, vê-se a falta de critérios mais claros por parte da União, para indicar concretamente aos Ministros o verdadeiro impacto dessa decisão, ficando em um campo da incerteza.

Além do mais, como não poderia deixar de ser, perde toda a tecnicidade que deve ter e utiliza-se de argumento exclusivamente de cunho econômico, na seguinte conjugação verbal:

Confrontado com uma posição do STF que produza impactos profundos no sistema tributário, como é o presente caso, o governo pode adotar uma de três posições para contrabalançar a perda de arrecadação e as restituições daí decorrentes:

a) Aumentar alíquotas, para compensar a redução da base de cálculo, e/ou reduzir gastos na seguridade social;

b) Endividar-se;

c) Não fazer nada e deixar que a inflação realize o ajuste necessário ${ }^{13}$.

Segue a sua exposição asseverando que a opção menos gravosa seria a opção "a", porém, afetaria a todos os contribuintes, enquanto que com essa tese apenas uma parcela de contribuintes se beneficiariam e, esses contribuintes, nem sequer arcaram com os custos tributários, pois o seu custo foi transladado para o consumidor final.

Trata, também de uma tese atinente à questão procedimental no âmago da Receita Federal, expondo que esta não disponibilizaria dos dados para aplicar a decisão em questão, perfilhando sua deficiência em encontrar bases exatas para a restituição.

Basicamente, as teses suscitadas quanto à modulação, são essas. Ao final pugna pela modulação dos efeitos para aplicação do efeito ex nunc, após o julgamento dos embargos de declaração.

A parte que defende os interesses dos contribuintes, foi chamada a se pronunciar em sede de manifestação aos embargos de declaração. Com relação especificamente à modulação dos efeitos, assevera que a União não comprova cabalmente os supostos prejuízos que diz que haverá se não houver a modulação dos efeitos, fazendo constatação de que é "imprescindível que a alegação sobre a qual se fundamenta o pedido de modulação de efeitos, quando levantada pela parte interessada, esteja robustamente comprovada. Essa é a firme orientação sufragada por este E. Supremo Tribunal Federal", com fulcro no Recurso Extraordinário nº 634.578/MG.

\footnotetext{
${ }^{13}$ Disponível em: <https://www.conjur.com.br/dl/embargos-pgfn-icms-pis-cofins.pdf $>$. Acesso em: 02 maio 2018.
} 
E seguem os advogados, asseverando que "a mera especulação sobre o montante pretensamente envolvido na lide, como também acerca do eventual impacto sistêmico, não é suficiente para embasar o excepcional e inusitado pedido de modulação, que deve necessariamente vir acompanhado de provas"14.

Além do mais, faz interessante apontamento, realizando um flash back da decisão do RE $n^{\circ} 240.785$, que remonta em 2006, ou seja, mais de uma década passada, o que evidencia que o Fisco “colocou-se na confortável posição de refém de sua própria estratégia protelatória”, ocasião em o Supremo definiu pela inconstitucionalidade dessa tese, ou seja, o Fisco teve mais de dez anos para se adequar e/ou retificar a lei. Porém, não tomou qualquer medida, querendo agora, ao arrepio do bom senso, modular os efeitos de algo que poderia ter se preparado.

Essa postura faz lembrar o postulado do venire contra factum proprium, em que é vedado o comportamento contraditório, devendo as partes agir com condutas éticas e de boafé. Sem dúvida a conduta da União que não entendeu o alcance da decisão do Supremo em idos de 2006 e contou com a demora do Judiciário, agora não pode querer a modulação dos efeitos.

\begin{abstract}
A vedação do comportamento contraditório (venire contra factum proprium) não é expressamente regulada no ordenamento jurídico brasileiro. Entretanto, é corolário do princípio da boa-fé. Sabe-se que a boa-fé objetiva é princípio limitador do exercício de autonomia nas relações privadas, impondo cooperação e lealdade entre as partes e vedando condutas contraditórias ${ }^{15}$.
\end{abstract}

Assim, o "Fisco colocou-se na confortável posição de refém de sua própria estratégia protelatória"16.

Outro ponto que chama a atenção na manifestação do contribuinte é com relação ao suposto desequilíbrio financeiro que abruptamente poderá ocorrer se não houver a modulação. Isso deve ser flexibilizado, uma vez que os contribuintes favorecidos com a decisão terão alguns caminhos a trilhar para gozar da restituição:

\footnotetext{
${ }^{14}$ Disponível em: $<$ http://redir.stf.jus.br/estfvisualizadorpub/jsp/consultarprocessoeletronico/ConsultarProcesso Eletronico.jsf?seqobjetoincidente $=2585258>$. Acesso em: 02 maio 2018.

${ }^{15}$ AYRES, Beatriz Flores. A proibição do comportamento contraditório no direito brasileiro. Disponível em: $<$ http://revistas.unibh.br/index.php/dcjpg/article/viewFile/85/48>. Acesso em: 07 maio 2018.

${ }^{16}$ Disponível em: $<$ http://redir.stf.jus.br/estfvisualizadorpub/jsp/consultarprocessoeletronico/ConsultarProcesso Eletronico.jsf?seqobjetoincidente $=2585258>$. Acesso em: 02 maio 2018.
} 
[...] pela longa via do precatório; pela habilitação e compensação, sob rigorosa fiscalização da Receita Federal; e finalmente pelo levantamento dos depósitos judiciais, que só há de ocorrer após escrutínio da Fazenda Nacional, com eventual pedido de penhora de importâncias para garantia de outros débitos fiscais ${ }^{17}$.

Note, portanto, que não ocorrerão perdas como estima a União de uma só vez, haja vista as ferramentas disponíveis ao contribuinte para fazer sua compensação.

No caso dos precatórios, os pagamentos ocorrerão nos termos definidos pela Constituição Federal, após trâmite judicial do cumprimento de sentença em face da União e verificando se o contribuinte não possui débitos perante a Receita, que poderão ser compensados antes do recebimento.

Na compensação, existem vários critérios legais impostos para o procedimento, além do que não haverá uma compensação única e imediata, pois dependerá dos tributos federais devidos pelo contribuinte mensalmente.

O pedido de levantamento de depósito judicial é o menos gravoso, haja vista que os valores sequer entraram nos cofres da União, estando em uma conta judicial sob os auspícios do juízo da causa. Ademais, como mencionado dependerão de prévia outorga fazendária e tudo sob o crivo do juiz competente.

Sem perder de vista que esses valores restituídos aos contribuintes serão injetados na economia e, com isso, a União irá angariar novos tributos, aumentando a arrecadação e com essa movimentação na economia, ocorrerá o respectivo aumento do PIB - Produto Interno Bruto.

Hamilton Dias de Souza e Daniel Côrrea Szelbracikowsk elucidam que não deverão ser modulados, uma vez que não presentes os requisitos:

\begin{abstract}
Não nos parece haver justificativa razoável para a atribuição de efeitos prospectivos ao julgamento, pois não houve surpresa ao Fisco. Ao contrário, houve mera reiteração de entendimento adotado pelo Plenário do STF desde 2014 (RE 240.785/MG, DJe 16/12/2014), a afastar a excepcionalidade que justifica referida modulação. Mas, na hipótese de o STF eventualmente modular os efeitos da declaração de inconstitucionalidade, deverá, no mínimo, preservar o direito dos que discutiram a constitucionalidade da exação até a finalização do julgamento ${ }^{18}$.
\end{abstract}

\footnotetext{
${ }^{17}$ Disponível em: <http://redir.stf.jus.br/estfvisualizadorpub/jsp/consultarprocessoeletronico/ConsultarProcesso Eletronico.jsf?seqobjetoincidente=2585258>. Acesso em: 02 maio 2018.

${ }^{18}$ SOUZA, Hamilton Dias de; SZELBRACIKOWSKI, Daniel Côrrea. Na área tributária, Supremo buscou manter estabilidade de seus precedentes. Disponível em: <https://www.conjur.com.br/2018-jan-01/area-tributaria-stfbuscou-manter-estabilidade-precedentes $>$. Acesso em: 07 maio 2018.
} 
Feitas essas ponderações, há argumentos factíveis de ambos os lados e o Supremo terá essa árdua missão, nos próximos meses, para definir pela modulação ou não dessa tese tão importante. Não se pode esquecer de relembrar a existência de duas súmulas antigas do STJ Superior Tribunal de Justiça, contrário à tese da exclusão do ICMS, que poderá pesar quando do julgamento.

É de grande valia que o Supremo evidencie ao apreciar o caso em tela, todos os aspectos debatidos nesse artigo, para fugir do subjetivismo exacerbado do artigo 27, da Lei 9.868/1999, criando com esse julgamento um critério objetivo e em obediência aos primados da Constituição Federal, não perdendo de vista que esse julgamento trará reflexos das mais variadas conotações.

\section{Conclusões}

O controle de constitucionalidade jurisdicional é aquele realizado pelo Poder Judiciário, com o fito de retirar um ato normativo contrário à Constituição Federal. O principal autor desse controle é o STF, que faz as vezes de corte constitucional.

O controle difuso é feito de forma incidental, por meio das lides que chegam ao conhecimento do Poder Judiciário e o controle concentrado é feito por meio de ações típicas dispostas pelo texto constitucional e com os legitimados especificados, com o fito de impugnar a lei ou ato normativo em tese.

$\mathrm{O}$ efeito no controle difuso, em regra, é ex tunc e inter partes, enquanto que no concentrado ex tunc e erga omnes.

Todavia, esses efeitos podem e devem ser flexibilizados se obedecidos os critérios do artigo 27, da Lei $n^{\circ} 9.868 / 1999$. Isso também deve ser feito na seara tributária, pois o tributo foi incorporado no preço do produto ou do serviço. Assim, mesmo que afastado, tempos depois, teve repercussão e, esta é muitas vezes irreversível ou de difícil reversão.

No caso do artigo exposto e que ainda pende de julgamento, é o da exclusão do ICMS da base de cálculo do PIS e da COFINS, que teve vitória no mérito em favor dos contribuintes e, agora, a União pretende a modulação dos efeitos, arguindo teses de ordem jurídica e do problema de cunho econômico, tendo em vista uma suposta perda de arrecadação e de devolução de recurso na casa dos trezentos bilhões de reais. É um caso interessante e que também tem muitos aspectos jurídicos importantes, uma vez que alguns tribunais regionais 
eram favoráveis à tese, outros não e o STJ tem duas Súmulas contrárias à tese. Assim, o Supremo terá que observar vários pontos para apreciar esse caso no que toca à modulação dos efeitos.

O Supremo ao analisar essa questão da modulação dos efeitos na tese apontada deve analisar com cautela se presentes realmente os requisitos autorizadores da modulação, não utilizando apenas de critérios de suposto rombo nas contas públicas, pois deve observar o que a lei determina, para efetivamente atender à supremacia da Constituição Federal.

A questão da modulação dos efeitos ganha mais complexidade quando se trata de temas tributários, pois o tributo tem um papel fundamental na estrutura constitucional e, por muitas das vezes, impacta diretamente nas contas públicas, uma vez que o tributo declarado inconstitucional é sabido que o recurso adquirido foi utilizado para a consecução do estado e, assim, para restituir haverá impacto nas contas. Porém, isso isoladamente não pode ser considerado, devendo buscar bases na segurança jurídica e interesse social, não apenas questões unicamente de cunho econômico.

\section{Referências bibliográficas}

AGRA, Walber de Moura. Aspectos controvertidos do controle de constitucionalidade. Salvador: JusPodivm, 2008.

AYRES, Beatriz Flores. A proibição do comportamento contraditório no direito brasileiro. Disponível em: <http://revistas.unibh.br/index.php/dcjpg/article/viewFile/85/48>. Acesso em: 07 jan. 2018.

BRASIL. Câmara dos Deputados. Exposição de motivos da Lei $n^{\circ}$ 9.868. Disponível em: $<$ http://www2.camara.leg.br/legin/fed/lei/1999/lei-9868-10-novembro-1999-369587exposicaodemotivos-150030-pl.html>. Acesso em: 27 abr. 2018.

BRASIL. Supremo Tribunal Federal. Informativo $n^{\circ}$ 161. Disponível em: $<$ http://www.stf.jus.br/arquivo/informativo/documento/informativo161.htm>. Acesso em: 07 maio 2018. 
BRASIL. Supremo Tribunal Federal. Informativo $n^{\circ}$ 437. Disponível em:

$<$ http://www.stf.jus.br/arquivo/informativo/documento/informativo437.htm>. Acesso em: 07 maio 2018.

BRASIL. Supremo Tribunal Federal. Informativo $n^{\circ}$ 762. Disponível em:

$<$ http://www.stf.jus.br/arquivo/informativo/documento/informativo762.htm>. Acesso em: 07 maio 2018.

BRASIL. Supremo Tribunal Federal. Informativo $n^{\circ}$ 856. Disponível em:

$<$ http://www.stf.jus.br/arquivo/informativo/documento/informativo856.htm>. Acesso em: 07 maio 2018.

BRASIL. Supremo Tribunal Federal. Informativo $n^{\circ}$ 857. Disponível em:

$<$ http://www.stf.jus.br/arquivo/informativo/documento/informativo857.htm>. Acesso em: 07 maio 2018.

BRASIL. Supremo Tribunal Federal. Ação Declaratória de Constitucionalidade $n^{\circ} 18$, Relator(a): Min. MENEZES DIREITO, Tribunal Pleno, julgado em 13/08/2008, DJe-202 DIVULG 23-10-2008 PUBLIC 24-10-2008. Disponível em:

$<$ http://www.stf.jus.br/portal/inteiroTeor/obterInteiroTeor.asp?id=557251>. Acesso em: 05 maio 2018.

BRASIL. Supremo Tribunal Federal. Ação Declaratória de Constitucionalidade $n^{\circ} 18$, Questão de Ordem, Relator(a): Min. MENEZES DIREITO, Tribunal Pleno, julgado em 04/02/2009, DJe-071 DIVULG 16-04-2009 PUBLIC 17-04-2009. Disponível em: $<$ http://www.stf.jus.br/portal/inteiroTeor/obterInteiroTeor.asp?id=586935>. Acesso em: 05 maio 2018.

BRASIL. Supremo Tribunal Federal. Ação Declaratória de Constitucionalidade $n^{\circ} 18$, Questão de Ordem 2, Relator(a): Min. MENEZES DIREITO, Tribunal Pleno, julgado em 6/09/2009, DJe-200 DIVULG 22-10-2009 PUBLIC 23-10-2009. Disponível em: $<$ http://www.stf.jus.br/portal/inteiroTeor/obterInteiroTeor.asp?id=604541>. Acesso em: 05 maio 2018. 
BRASIL. Supremo Tribunal Federal. Ação Declaratória de Constitucionalidade $n^{\circ} 18$, Questão de Ordem 3, Relator(a): Min. MENEZES DIREITO, Tribunal Pleno, julgado em 25/03/2010, DJe-110 DIVULG 17-06-2010 PUBLIC 18-06-2010. Disponível em: $<$ http://www.stf.jus.br/portal/inteiroTeor/obterInteiroTeor.asp?id=612343>. Acesso em: 05 maio 2018.

BRASIL. Supremo Tribunal Federal. Notícia do STF. Partes e PGR apresentam argumentos ao Plenário sobre inclusão do ICMS na base de cálculo de contribuições. Disponível em: $<$ http://www.stf.jus.br/portal/cms/verNoticiaDetalhe.asp?idConteudo=337926\&caixaBusca $=$ $\mathrm{N}>$. Acesso em 07 maio 2018.

BRASIL. Supremo Tribunal Federal. Recurso Extraordinário $n^{\circ}$ 240.785, Relator(a): Min. MARCO AURÉLIO, Tribunal Pleno, julgado em 08/10/2014, DJe-246 DIVULG 15-12-2014 PUBLIC 16-12-2014. Disponível em: <http://stf.jus.br/portal/inteiroTeor/obterInteiro Teor.asp?id=630123>. Acesso em: 05 maio 2018.

BRASIL. Supremo Tribunal Federal. Recurso Extraordinário $n^{\circ}$ 574.706. Petição dos Embargos de Declaração da União. Disponível em: $<$ https://www.conjur.com.br/dl/embargospgfn-icms-pis-cofins.pdf>. Acesso em: 02 maio 2018.

BRASIL. Supremo Tribunal Federal. Recurso Extraordinário $n^{\circ} 634.578$ Embargos de Declaração, Relator(a): Min. JOAQUIM BARBOSA, Segunda Turma, julgado em 08/05/2012, ACÓRDÃO ELETRÔNICO DJe-102 DIVULG 24-05-2012 PUBLIC 25-052012. Disponível em: $<$ http://stf.jus.br/portal/inteiroTeor/obterInteiroTeor.asp?idDocumento=2056675> $>$. Acesso em: 05 maio 2018.

BRASIL. Supremo Tribunal Federal. Proposta de Súmula Vinculante $n^{o}$ 69. Disponível em: $<$ http://www.stf.jus.br/portal/jurisprudenciaRepercussao/verTeseTema.asp?numTema=69>. Acesso em: 07 maio 2018.

BRÍGIDO, Carolina. Decisão do STF sobre base de cálculo do PIS/Cofins reduzirá em R\$27 bilhões a arrecadação federal. Disponível em: <https://oglobo.globo.com/economia/decisao- 
do-stf-sobre-base-de-calculo-do-piscofins-reduzira-em-27-bilhoes-arrecadacao-federal21067057>. Acesso em: 07 maio 2018.

CUNHA JÚNIOR, Dirley da Cunha. Controle de constitucionalidade: teoria e prática. 8. ed., Salvador: Juspodivm, 2016.

CUNHA, Frederico. STF publica acórdão que exclui ICMS da base de cálculo do PIS/Cofins. Disponível em: <http://www.migalhas.com.br/Quentes/17,MI267432,71043$\mathrm{STF}+$ publica + acordao + que + exclui $+\mathrm{ICMS}+$ da + base + de + calculo + do + PISCofins $>$. Acesso em: 07 maio 2018.

FRANCISNO, Glaucia Maria Lauletta. Os 250 bilhões e o 'dilema' do Supremo Tribunal Federal. Disponível em: <http://politica.estadao.com.br/blogs/fausto-macedo/os-250-bilhoese-o-dilema-do-supremo-tribunal-federal/>. Acesso em: 07 maio 2018.

MODESTO, Vagner Cristiano. O ICMS e a sua não incidência na base de cálculo da contribuição para o PIS e da COFINS: constitucionalidade e novas perspectivas. In: AKEL, Michelle Heloise; GRILLO, Fabio Artigas; TAROSSO, Fabriccio Petreli; MOROSINI, Matheus Monteiro (Org.). Direito Tributário Paranaense: homenagem ao prof. Dr. George Bueno Gomn, vol. II. Curitiba: Instituto Memória, 2017, p. 139-171.

OLIVEIRA, Lourival José; FERRER, Walkiria Martinez Heinrich. Da inconstitucionalidade da denúncia feita à convenção $n^{\circ} 158$ da OIT: impossibilidade de limitação de seus efeitos frente à violação de direito social. Revista Argumentum, v. 18, n. 1, jan./abr. 2017, p. 125 146. Disponível em: <http://ojs.unimar.br/index.php/revistaargumentum/article /view/340/90>. Acesso em: 20 abr. 2018.

OLIVEIRA, Ribamar. Tributaristas preveem onda de contestações. Disponível em: $<$ http://www.valor.com.br/brasil/4902732/tributaristas-preveem-onda-decontestacoes>.Acesso em: 07 maio 2018.

OLIVON, Beatriz. União perderá $R \$ 20$ bi por ano com decisão do STF sobre cálculo da Cofins. Disponível em: <http://www.valor.com.br/legislacao/4901162/uniao-perdera-r-20-bipor-ano-com-decisao-do-stf-sobre-calculo-da-cofins>. Acesso em: 07 maio 2018. 
PIMENTEL, João Otávio Martins. Expectativas sobre a exclusão do ICMS da base de cálculo do PIS e da Cofins. Disponível em: <http://www.migalhas.com.br/dePeso /16,MI209242,31047Expectativas + sobre $+\mathrm{a}+$ exclusao + do $+\mathrm{ICMS}+\mathrm{da}+\mathrm{base}+\mathrm{de}+$ calculo $+\mathrm{do}+\mathrm{P}$ IS + e+da>. Acesso em: 07 maio 2018.

ROTHENBURG, Walter Claudius. Direito Constitucional. São Paulo: Verbatim, 2010.

SALUSSE, Eduardo. STF sugere que irá modular efeitos da exclusão do ICMS do PIS/Cofins. Disponível em: <http://www.valor.com.br/legislacao/fio-dameada/5146688/perspectivas-na-exclusao-do-icms-da-base-de-calculo-do-pis-e-da-cofi> . Acesso em: 02 maio 2018.

SOUZA, Hamilton Dias de; SZELBRACIKOWSKI, Daniel Côrrea. Na área tributária, Supremo buscou manter estabilidade de seus precedentes. Disponível em:

$<$ https://www.conjur.com.br/2018-jan-01/area-tributaria-stf-buscou-manter-estabilidadeprecedentes $>$. Acesso em: 07 maio 2018.

VELANO, Emília Maria. Modulação dos efeitos da declaração de inconstitucionalidade de lei tributária. Curitiba: Juruá, 2011. 


\title{
O CONCEITO DE TAXA E A ESSENCIALIDADE DO SERVIÇO PÚBLICO: ANÁLISE DO TEMA No 16 DA REPERCUSSÃO GERAL NO SUPREMO TRIBUNAL FEDERAL
}

\author{
Antônio Carlos Diniz Murta \\ Universidade FUMEC \\ Carlos Victor Muzzi Filho \\ Universidade FUMEC
}

\section{Resumo}

O artigo, empregando abordagem jurídico-dogmática, discute a Tese $n^{\circ} 16$ da Repercussão Geral do Supremo Tribunal Federal (STF), segundo a qual o serviços público de prevenção e combate a incêndio, por ser "essencial", não poderiam ser remunerado por taxa. O artigo, depois de demonstrar que o argumento baseado na essencialidade do serviço público não foi aceito pela maioria dos Ministros, critica este argumento, demonstrando o equívoco em sua adoção. $\mathrm{O}$ artigo ainda critica a afirmação de que o serviço público essencial deveria ser custeado pela receita de impostos, dada a fragilidade jurídica dessa espécie de distinção.

Palavras-chave: Direito Tributário, Taxa, Serviço público essencial, Prevenção e combate a incêndio, Crítica ao Tema no 16 da Repercussão Geral.

\section{Abstract/Resumen/Résumé}

The article, using a legal-dogmatic approach, discusses Thesis $\mathrm{n}^{\mathrm{o}} 16$ of the General Repercussion of the Brasilian Supreme Court (STF), according to which the public services of prevention and fire fighting, being "essential", could not be remunerated per charge. The article, after demonstrating that the argument based on the essentiality of the public service was not accepted by the majority of Ministers, criticizes this argument, demonstrating the misconception in its adoption. The article also criticizes the claim that the essential public service should be funded by tax revenue, given the legal fragility of this kind of distinction.

Keywords/Palabras-claves/Mots-clés: Tax law, Tax. Essential public service, Prevention and fire fighting, Critique of Theme 16 of the General Repercussion. 


\title{
1. Introdução
}

O conceito de taxa é um daqueles temas tributários envolto em perenes discussões, ou, na expressão de Sacha Calmon Navarro Coêlho, é "uma das esquinas da tributarística, onde o estudioso fica perplexo sobre o caminho a seguir" (COÊLHO, 2010:401). No sistema tributário brasileiro, até há conceito legal de taxa, contido no já cinqüentenário Código Tributário Nacional (CTN, Lei n ${ }^{\circ}$ 5.172, de 25 de outubro de 1966, artigos 77 a 80). E esse conceito legal foi sendo incorporado aos textos constitucionais que se seguiram ao CTN, a começar pela Emenda Constitucional $\mathrm{n}^{\mathrm{o}} 18$, de $1^{\mathrm{o}}$ de dezembro de 1965 (artigo 18), que dispôs sobre a "Reforma do sistema tributário", passando pela Constituição da República de 1967 (artigo 19, inciso II), pela Emenda Constitucional n ${ }^{\circ}$ 1, de 17 de outubro de 1969 (artigo 18, inciso I), até chegar à vigente Constituição da República de 1988 (CR/1988, artigo 145, inciso II). Ainda assim, não se pacificou, em termos doutrinários e jurisprudenciais, o conceito de taxa, renovando-se, de tempos em tempos, as polêmicas em torno dele, notadamente da definição dos serviços específicos e divisíveis que podem ser definidos como fato gerador daquela espécie tributária.

Novo capítulo dessa história foi acrescentado pelo Supremo Tribunal Federal (STF) ao apreciar, em dezembro de 2017, o Tema n 16 da Repercussão Geral, objeto do Recurso Extraordinário (RE) no 643.247/SP, Pleno, Relator (Rel.) Ministro (Min.) Marco Aurélio, no qual foi assentada a seguinte tese:

\begin{abstract}
A segurança pública, presentes a prevenção e o combate a incêndios, faz-se, no campo da atividade precípua, pela unidade da Federação, e, porque serviço essencial, tem como a viabilizá-la a arrecadação de impostos, não cabendo ao Município a criação de taxa para tal fim (BRASIL, 2017:136).
\end{abstract}

Veja-se que o STF afastou a possibilidade de se exigir taxa em relação à "atividade" de prevenção e combate a incêndios, porque, sendo "serviço essencial, tem como a viabilizá-la a arrecadação de impostos" ". Destacam-se, pois, no enunciado da tese, as alusões ao "serviço essencial" e à determinação de que o custeio de tal serviço se faça por meio da "arrecadação de impostos".

\footnotetext{
${ }^{1}$ Informações completas sobre o Tema $\mathrm{n}^{\circ} 16$, bem como sobre todos os demais Temas, são encontradas no "site" do Supremo Tribunal Federal, disponíveis em http://www.stf.jus.br/portal/jurisprudenciaRepercussao $/$ verAndamentoProcesso.asp incidente $=4084500 \&$ numeroProcesso $=643247 \&$ classeProcesso $=\mathrm{RE} \&$ numeroTema $=16$, acesso em 10.jan.2018.
} 
Literalmente, porém, o vigente texto constitucional não cogita da essencialidade do serviço público como requisito para exigência das taxas, eis que a CR/1988 se refere à possibilidade de União, Estados, Distrito Federal e Municípios instituírem “taxas, em razão do exercício do poder de polícia ou pela utilização, efetiva ou potencial, de serviços públicos específicos e divisíveis, prestados ao contribuinte ou postos a sua disposição" (artigo 145, inciso II). Os serviços públicos que podem ser fato gerador das taxas devem ser "específicos e divisíveis", mas não "essenciais", ao menos nos termos literais, repita-se, da CR/1988. Ainda assim, o STF, no aludido Tema $\mathrm{n}^{\circ} 16 \mathrm{da}$ Repercussão Geral, invocou a natureza essencial da atividade de prevenção e combate a incêndios para concluir não ser válida a taxa instituída pelo Município de São Paulo.

Ademais, também se distinguiu as espécies tributárias - taxa e imposto - a partir da destinação dada ao produto arrecadado, porque se afirmou que os impostos, e não as taxas, deveriam custear os serviços considerados essenciais.

Este trabalho tem por objeto, então, examinar e criticar esses dois aspectos da tese firmada pelo STF no Tema $n^{\circ} 16$ da Repercussão Geral, entendendo que eles carecem de fundamentação teórica mais consistente, representando substancial modificação da jurisprudência do próprio STF. Além de abordar relevante questão teórica em torno do conceito jurídico de taxa, este trabalho ainda tem importância prática, na medida em que a decisão do STF deve ser obrigatoriamente adotada pelos demais órgãos do Poder Judiciário e pela Administração Pública, dadas as regras contidas no artigo 1.039 do vigente Código de Processo Civil (CPC/2015), Lei n ${ }^{\circ}$ 13.105, de 16 de março de 2015.

Em termos estruturais, o trabalho será divido em dois tópicos, além desta introdução e do tópico de conclusão.

No primeiro tópico, se examinará a decisão do STF, com exame dos fundamentos adotados no julgamento do RE 643.247/SP. A bem da verdade, sob a ótica processual, o exame desses fundamentos justificaria, por si só, a produção de artigo específico, porque, na realidade, a "essencialidade" do serviço público não foi fundamento adotado pela maioria dos Ministros do STF, malgrado tenha sido incorporada à tese firmada na conclusão do julgamento. Todavia, o artigo se concentrará no aspecto tributário da discussão. A discussão, aqui, está concentrada na questão tributária, embora sejam feitas, de passagem, menções aos temas processuais mais relevantes envolvidos no julgamento do Tema $n^{\circ} 16$ da Repercussão Geral.

No segundo tópico, os fundamentos adotados pelo STF serão confrontados com o entendimento doutrinário a respeito das taxas e também com a própria jurisprudência do STF, a fim de demonstrar a inconsistência da tese firmada no aludido Tema ${ }^{\circ} 16$. 
Ajusta-se, assim, o presente trabalho à linha de pesquisa do grupo de trabalho sobre Direito Financeiro e Tributário, por enfrentar questão importante sobre o sistema tributário nacional, questão esta que repercute na própria teoria geral do Direito Tributário, por dizer respeito ao conceito jurídico de taxa.

Metodologicamente, a abordagem será jurídico-dogmática, nos termos propostos por Miracy Gustin e Maria Tereza Fonseca Dias (GUSTIN; DIAS, 2006:21), assentando-se o trabalho, precipuamente, em pesquisa bibliográfica, demonstrando-se, como se pretende, a fragilidade teórica da tese firmada pelo STF.

\section{Compreendendo a decisão do stf tema $\mathbf{n}^{0} \mathbf{1 6}$}

No Tema no 16 da Repercussão GEral, objeto do RE nº 643.247/SP, Pleno, Rel. Min. Marco Aurélio, discutiu-se a constitucionalidade da Lei Municipal ${ }^{\circ} 8.822$, de 24 de novembro de 1978, do Município de São Paulo, que instituiu a "Taxa de Combate a Sinistros"2 (BRASIL, 2017:137), mais comumente chamada taxa de (combate a) incêndios, cujo fato gerador é a prestação de serviço público de combate a incêndios em prédios, exigida pelo fato de o serviço de combate a incêndios estar à disposição do sujeito passivo (normalmente, o proprietário de imóvel).

O Tribunal de Justiça de São Paulo (TJSP), em ação promovida pelo Estado de São Paulo, que, no caso, era o contribuinte da taxa, havia reconhecido a inconstitucionalidade da referida taxa, baseando-se em dois fundamentos, como consta no relatório do RE $\mathrm{n}^{\mathrm{o}}$ 643.247/SP: a) o serviço público de combate a incêndios era de competência estadual, e não municipal; e b) o serviço público não era específico e divisível (BRASIL, 2017:137)³.

No recurso extraordinário, ainda segundo o relatório do acórdão, o Município de São Paulo, então recorrente, afirmou que a competência municipal para organizar e prestar o serviço de combate a incêndio decorreria da previsão do art. 182 da CR/1988, "segundo o qual seria dever dos Municípios organizar e disciplinar o uso da propriedade imóvel”, insistindo, também,

\footnotetext{
${ }^{2}$ Dispunha o artigo $1^{\circ}$ da Lei Municipal 8.822, de 1978: "A Taxa de Combate a Sinistros é devida pela utilização efetiva ou potencial dos serviços municipais de assistência, combate e extinção de incêndios ou de outros sinistros em prédios". A "Taxa de Combate a Sinistros" foi revogada pela Lei Municipal no 12.782 , de 30 de dezembro de 1998. No Município de São Paulo, assim, já não mais se exige a "Taxa de Combate a Sinistros", mas taxas semelhantes existem em outros Municípios e Estados (por exemplo, no Estado de Minas Gerais, nos termos do art. 113, inciso IV, da Lei Estadual $n^{\circ} 6.763$, de 26 de dezembro de 1976, com a redação dada pela Lei Estadual ${ }^{\circ}$ 14.938, de 29 de dezembro de 2003; no Estado do Rio de Janeiro, art. 107 e Anexo II, item no 12, do Decreto-lei $\mathrm{n}^{\circ}$ 5, de 15 de março de 1975, com alteração da Lei Estadual ${ }^{\circ}$ 7.175, de 28 de dezembro de 2015).

${ }^{3}$ Vale registrar que o Min. Marco Aurélio tem por hábito registrar o assessor que elaborou o relatório de seus julgados, sendo que, no caso, averbou que adotava, "[...] como relatório, as informações prestadas pelo assessor Dr. Pedro Júlio Sales D’Araújo" (BRASIL, 2017:137).
} 
no caráter específico e divisível do serviço, "[...] presente a possibilidade de determinar-se os beneficiados pela prestação estatal e a respectiva utilização [...]" (BRASIL, 2017:138). Ainda argumentou ser legítima a adoção, como base de cálculo da taxa, ainda que considerada a metragem do imóvel na referida base de cálculo (BRASIL, 2017:138).

Já o Estado de São Paulo, parte recorrida, insistiu na tese de que o serviço de combate a incêndio é prestado "[...] pelo Corpo de Bombeiros vinculado à estrutura estadual, não havendo demonstração do Município em sentido contrário", além de também insistir no argumento sobre a "[...] inexistência de especificidade e divisibilidade do serviço público" (BRASIL, 2017:138). Também questionou a “[...] ausência de relação entre o custo do serviço prestado e os elementos integrantes da base de cálculo do tributo" (BRASIL, 2017:139).

Considerando-se o relatório do acórdão, é correto afirmar que, no âmbito do TJSP, não se instaurou discussão sobre a essencialidade, ou não, do serviço de combate a sinistros, o que suscitaria, por, si, importante discussão no plano processual. Isso porque o Supremo Tribunal Federal exige, para admissão do recurso extraordinário, que tenha havido o chamado prequestionamento da questão constitucional (Súmula $\left.n^{0} 282\right)^{4}$. Esta discussão, porém, ultrapassa os objetivos deste artigo.

O voto do Relator, Min. Marco Aurélio, invocou o entendimento do Supremo Tribunal Federal firmado na Medida Cautelar na Ação Direta de Inconstitucionalidade $n^{\circ}$ 1.942/PA, Pleno, Rel. Min. Moreira Alves, assinalando que a prevenção e o combate a incêndio são atividades de defesa civil, nos termos do art. 144 da CR/1988, integrando, pois, as atividades de "segurança pública", de competência dos Estados, e não dos Municípios:

O rol de órgãos constantes do citado artigo [art. 144 da CR/1988, esclareça-se] revela a junção das polícias militares e dos corpos de bombeiros militares. Às primeiras cabem a polícia ostensiva e a preservação da ordem pública. Já aos corpos de bombeiros militares, além das atribuições definidas em lei, incumbe a execução de atividade de civil. Neste último gênero inclui-se a prevenção e o combate a incêndio. As funções surgem essenciais, inerentes e exclusivas ao próprio Estado, no que detém o monopólio da força. Inconcebível é que, a pretexto de prevenir sinistro relativo a incêndio, venha o Município a substituir-se ao Estado, fazendo-o por meio da criação de tributo sob o rótulo taxa (BRASIL, 2017:141)

Em seguida, o Min. Marco Aurélio, realçando que a segurança pública seria "atividade precípua" do Estado, pontuou que essas atividades haveriam de ser custeadas, não por taxas,

\footnotetext{
${ }^{4}$ Explica José Miguel Garcia Medina que “o prequestionamento tem por objeto a questão federal ou constitucional, sendo, assim, meio através do qual se leva ao conhecimento do órgão a quo a referida questão, a fim de que seja decidida. A questão federal ou constitucional deverá estar presente na decisão recorrida, e poderá surgir mesmo que ausente a provocação de qualquer das partes" (MEDINA, 2017:118).
} 
mas por impostos:

Repita-se à exaustão - atividade precípua do Estado é viabilizada mediante arrecadação decorrente de impostos, pressupondo a taxa o exercício do poder de polícia ou a utilização efetiva ou potencial de serviços públicos específicos e divisíveis, prestados ao contribuinte ou postos à disposição. Nem mesmo o Estado poderia, no âmbito da segurança pública revelada pela prevenção e combate a incêndios, instituir validamente a taxa, como proclamou o Supremo, embora no campo da tutela de urgência (BRASIL, 2017:141).

É evidente, no voto do Min. Marco Aurélio, a correlação entre a aplicação da receita tributária e a definição da espécie tributária, porque a "atividade precípua do Estado é viabilizada mediante arrecadação decorrente de impostos". Por esse motivo, na fixação da tese, considerou-se que a "prevenção e combate a incêndio", sendo "serviço essencial", deve ter "como a viabilizá-la a arrecadação de impostos", sendo incabível a taxa (BRASIL, 2017:141/142, passim). Anote-se que o voto do Min. Marco Aurélio foi bem sucinto, não mencionando, sequer, os precedentes que, no próprio STF, já haviam reconhecido a constitucionalidade de taxas de combate a incêndio instituídas por outros Municípios.

$\mathrm{Na}$ linha do voto do Min. Relator, que negou provimento ao recurso extraordinário (afirmando, pois, a inconstitucionalidade da taxa de combate a incêndio), caminharam os Ministros Edson Fachin, Rosa Weber, Ricardo Lewandowski e Cármen Lúcia. Esses votos, porém, não encamparam, expressamente, a tese da essencialidade do serviço público de combate a incêndio, embora também não a tenham rejeitado explicitamente.

De fato, o Min. Edson Fachin, no voto proferido no julgamento do Tema $n^{\circ} 16$ da Repercussão Geral, reconheceu que o STF, naquele julgamento, estava alterando a jurisprudência até então dominante, mencionando, especificamente, o RE 206.777, Pleno, Rel. Min. Ilmar Galvão, Diário de Justiça, 30.abr.1999 (BRASIL, 2017:146). O voto do Min. Edson Fachin, longamente fundamentado, não invocou a essencialidade do serviço público de combate a incêndio como causa de inconstitucionalidade material das taxas de combate a incêndio. Analiticamente, o Min. Edson Fachin relacionou os fundamentos pelos quais ele firmou sua convicção para "superar expressamente o precedente firmado no âmbito do RE 206.777" (BRASIL, 2017:148):

(i) a atividade de combate a incêndios e demais sinistros é serviço público geral e indivisível, portanto, deve ser remunerado por meio de impostos; (ii) a ausência de prestação de serviço público na espécie, pois a taxa foi criada para custear convênio administrativo entre os litigantes; e (iii) a inexistência de competência tributária do Município, à luz da fução constitucional da instituição Corpo de Bombeiros (BRASIL, 2017:148). 
Também o Min. Ricardo Lewandowski passou ao largo do argumento da essencialidade, acentuando, em seu voto, que o "argumento absolutamente definitivo" era o de que a taxa teria como fato gerador "um serviço não fruível uti singuli" (BRASIL, 2017:193). A natureza "universal", e não "essencial", do serviço de combate a incêndio também foi realçada no voto da Mina. Cármen Lúcia (BRASIL, 2017:203), embora tenha, ao final, referendado o entendimento do Relator, Min. Marco Aurélio, que, como já anotado, havia sublinhado a natureza "essencial" do serviço de combate a incêndios (BRASIL, 2107:209-210). A Minª Rosa Weber, por seu turno, não apresentou voto escrito.

Em sentido oposto, todavia, deram provimento ao recurso extraordinário (e, assim, reconheceram a constitucionalidade do tributo em questão), os Ministros Luiz Fux, Dias Toffoli, Alexandre de Moraes e Gilmar Mendes. Em seu voto, fazendo alusão ao entendimento até então dominante no STF, o Min. Luiz Fux observou que a taxa de combate a incêndio "só se referia a prédios construídos. Então, ela tinha um caráter de divisibilidade nesse sentido" (BRASIL, 2017:161). Ademais, pontuou que a segurança pública seria "da responsabilidade de todos”, razão pela qual a "defesa civil, que é uma instituição ligada a essas questões relativas aos sinistros em incêndios", poderia ser efetivada também pelos Municípios (BRASIL, 2017:161).

Destaque-se, aqui, o voto do Min. Roberto Barroso, que, na conclusão, acompanhou o Relator para negar provimento ao recurso extraordinário (formando, assim, a maioria de seis Ministros, dentre os onze Ministros que compõem o STF). O voto do Min. Roberto Barroso prendeu-se, contudo, à "inconstitucionalidade formal" da norma municipal, entendendo que "a Constituição é clara ao estabelecer no art. 144, inciso $\mathrm{V}, \S \S \S 5^{\circ}, 6^{\circ}$ e $7^{\circ}$ da $\mathrm{CF} / 88$ a competência Estadual para organizar as carreiras de Bombeiro Militar, a quem compete o serviço de combate a incêndios e o poder correlato nas edificações em geral” (BRASIL, 2017:158/159).

Portanto, o Min. Roberto Barroso não aderiu à tese da inconstitucionalidade material (segundo a qual o serviço público de combate a incêndios seria "serviço essencial", e, por isso, não se constituiria em fato gerador da taxa), de modo que, rigorosamente, não houve maioria de votos em favor dessa tese. Ainda assim, ela restou formulada de forma ampla, contemplando tanto a inconstitucionalidade formal (incompetência administrativa dos Municípios para prestar esse serviço público) e material (impossibilidade de serviço essencial se constituir em fato gerador da taxa).

Sob esse ângulo, o exame da decisão proferida no Tema n ${ }^{0} 16$ da Repercussão Geral comportaria interessante discussão sobre a formulação de teses da repercussão geral, que 
pressupõem maioria em torno da tese, e não da conclusão do julgado. Esta, todavia, é outra discussão que escapa dos limites do presente artigo, mas se faz o registro pela importância da questão.

Sintetizando, então, o que até aqui se expôs, segundo o entendimento firmado no Tema n 16 da Repercussão Geral, os serviços públicos “essenciais”, exatamente porque "essenciais", não podem se constituir em fato gerador de taxas, devendo ser custeados pela "arrecadação de impostos" (BRASIL, 2017:136). Nesse contexto, revelou-se secundária a questão relativa à incompetência administrativa dos Municípios para prestar o serviço público de combate a incêndio, porque, no próprio enunciado do Tema $n^{\circ} 16$ da Repercussão Geral, enfatizou-se a questão relativa à essencialidade do serviço público de combate a incêndio.

\section{A inconsistência dos critérios adotados}

O STF, ao se amparar, inicialmente, na ideia de "essencialidade" do serviço público de prevenção e combate a incêndio, e por causa dessa "essencialidade" afastar a incidência de taxa, ultrapassou, como já observado, a literalidade do dispositivo constitucional, visto que o art. 145, inciso II, da CR/1988, atribuiu aos entes federativos competência para instituir taxas sobre a prestação de serviços públicos, específicos e divisíveis. Ao recorrer à "essencialidade”, o STF ainda enveredou por caminho difícil, que é justamente definir a "essencialidade", ou não, de determinado serviço público.

A CR/1988 refere-se, é bem verdade, em alguns dispositivos, à essencialidade de alguns serviços ou atividades. Assim, o art. $9^{\circ}, \S 1^{\circ}$, da CR/1988, determina, ao tratar do "direito de greve", que a lei definirá "serviços ou atividades essenciais e disporá sobre o atendimento das necessidades inadiáveis da comunidade"5.

Já o art. 30, inciso V, da CR/1988, dispõe ser atribuição do Município organizar e prestar "serviços públicos de interesse local, incluído o de transporte coletivo, que tem caráter essencial".

Além disso, a vigente Constituição da República refere-se ainda a algumas instituições ou atividades públicas como essenciais. Assim, por exemplo, o Ministério Público e a

\footnotetext{
${ }^{5}$ A Lei $n^{\circ}$ 7.783, de 28 de junho de 1989, Lei do Direito de Greve, em seu art. 10, relaciona os "serviços ou atividades essenciais", a saber: "I - tratamento e abastecimento de água; produção e distribuição de energia elétrica, gás e combustíveis; II - assistência médica e hospitalar; III - distribuição e comercialização de medicamentos e alimentos; IV - funerários; V - transporte coletivo; VI - captação e tratamento de esgoto e lixo; VII telecomunicações; VIII - guarda, uso e controle de substâncias radioativas, equipamentos e materiais nucleares; IX - processamento de dados ligados a serviços essenciais; X - controle de tráfego aéreo; XI compensação bancária".
} 
Defensoria Pública, funções essenciais à justiça (art. 127 e art. 134 da CR/1988) ${ }^{6}$, as "administrações tributárias da União, dos Estados, do Distrito Federal e dos Municípios, atividades essenciais ao funcionamento do Estado" (art. 37, inciso XXII, da CR/1988) e ainda a "fiscalização e o controle sobre o comércio exterior, essenciais à defesa dos interesses fazendários nacionais" (art. 237 da CR/1988).

Essencialidade também é critério a ser aplicado ao Imposto sobre Produtos Industrializados (IPI, conforme art. $153, \S 3^{\circ}$, inciso I, da CR/1988) e ao Imposto sobre Circulação de Mercadorias e Serviços (ICMS, conforme art. 155, 2º inciso III, da CR/1988).

Nesse contexto, se o art. 145, inciso II, da CR/1988, refere-se a serviços públicos específicos e divisíveis, não se referindo a serviços públicos essenciais, já se poderia argumentar que o silêncio constitucional, aqui, foi eloquente. A essencialidade não é requisito para a instituição de taxas sobre a prestação de serviços públicos, ao menos se se partir de interpretação literal do texto constitucional.

Todavia, para além da literalidade do texto constitucional, há que se registrar ser extremamente imprecisa a definição de determinada prestação de serviço público como essencial (ou não-essencial), bastando recordar a diversidade da lista de atividades essenciais contida no art. 10 Lei $n^{\circ}$ 7.783, de 1989, a Lei do Direito de Greve. Referida lista alcança desde serviços que, na ordem jurídica brasileira, sequer são serviços públicos (a "distribuição e comercialização de medicamentos e alimentos", prevista no inciso III do art. 10; também a “compensação bancária”, prevista no inciso XI do mesmo art. 10), até serviços públicos que, atualmente, são serviços públicos concedidos à iniciativa privada (por exemplo, as "telecomunicações, prevista no inciso VII do art. 10; também a "produção e distribuição de energia elétrica, gás e combustíveis”, inciso I do art. 10), chegando a serviços prestados, indistintamente, por entidades públicas ou privadas ("assistência médica e hospitalar", por exemplo, prevista no inciso II do art. 10).

Por essa razão, mostra-se de duvidosa utilidade a definição de serviço público a partir de um critério material, como a "essencialidade" da prestação. Veja-se que Hely Lopes Meirelles, há décadas, já observava que “o conceito de serviço público é variável e flutua ao sabor das necessidades e contingências políticas, econômicas, sociais e culturais de cada comunidade, em cada momento histórico, como acentuam os modernos publicistas"

\footnotetext{
${ }^{6}$ No Título IV, "Da organização dos Poderes", Capítulo IV, a CR/1988 cuida, genericamente, das "Funções essenciais à justiça", contemplando, além do Ministério Público e da Defensoria Pública, a Advocacia Pública (art. 131) e a Advocacia (art. 133), sem as qualificar, específica e literalmente, como essenciais, embora o advogado seja considerado "indispensável à administração da justiça".
} 
(MEIRELLES, 1991: 289/290). Daí porque Hely Lopes Meireles adotava definição que, em verdade, apontava para a irrelevância da essencialidade, ou não, da atividade prestada para a identificação do serviço público, porque serviço público seria todo aquele "prestado pela Administração Pública ou por seus delegados [...] para satisfazer necessidades essenciais ou secundárias da coletividade, ou simples conveniências do Estado" (MEIRELLES, 1991:290).

Em obra mais recente, André Luiz Freire examinou os conceitos adotados por diversos administrativistas, registrando que Ruy Cirne Lima, em obra cuja primeira edição remonta à década de 1930, afirmava que "serviços públicos são apenas os serviços essenciais à sociedade (FREIRE, 2014:216) ${ }^{7}$. Todavia, André Luiz Freire cuidou de apontar os argumentos pelos quais o "critério material” (que vincula a definição de serviço público à essencialidade da prestação), "além de inútil para identificar uma tarefa como serviço público, traz riscos à própria esfera privada" (FREIRE, 2014:239-240).

Explicou Freire que os serviços bancários, por exemplo, de inegável importância nas sociedades contemporâneas, nunca foram, no Brasil, serviço público, embora sejam essenciais e atendam a "necessidades coletivas" (FREIRE, 2014:239). Por outro lado, invocando a lição de Luís Roberto Barroso, Freire anotou que os serviços lotéricos são qualificados como serviços públicos, no Brasil, malgrado não possam ser vistos como essenciais para a comunidade (FREIRE, 2014:239). Assim, prosseguiu André Luiz Freire, “o critério material” acaba por se basear em "concepção sociológica política ou econômica", que fica "ao sabor da subjetividade do julgador", resultando em "insegurança ao aplicador do direito positivo" (FREIRE, 2014:239).

De igual modo, Dinorá Adelaide Musetti Grotti (GROTTI, 2003:49-51) e Fernando Herren Aguillar (AGUILLAR, 2011:60-61) também rejeitam a tese de que a essencialidade possa ser característica que distinga o serviço público de outros tipos do serviço, justamente em razão da imprecisão de eventual conceito jurídico de essencialidade (GROTTI, 2003:49).

Pesquisando, por outro lado, a jurisprudência do STF, a partir da análise de cinco casos paradigmáticos (ADI n ${ }^{\circ}$ 1.221/RJ, Pleno, Rel. Min. Carlos Velloso, julgada em 2003; MC-ADI $\mathrm{n}^{\circ}$ 1.668/DF, Pleno, Rel. Min. Marco Aurélio, julgada em 2004; ADI n 2.649/DF, Pleno, Rel ${ }^{\mathrm{a}}$. Minª Cármen Lúcia, julgada em 2008; ADPF nº 46/DF, Pleno, Rel. Min. Eros Grau, julgada

\footnotetext{
${ }^{7}$ Ruy Cirne de Lima, de fato, sustentava que "serviço público é todo o serviço existencial, relativamente à sociedade ou, pelo menos, assim havido num momento dado, que, por isso mesmo, em de ser prestado aos componentes daquela, direta ou indiretamente, pelo Estado ou outra pessoa administrativa" (LIMA, 1987:82). Cirne de Lima, contudo, não define o que seria serviço "existencial", mas apenas encarece que, "porque existencial relativamente à sociedade, é que a prestação ao público tem de ser executada, direta ou indiretamente, pelo Estado ou outra pessoa administrativa", insistindo que "reside o traço característico principal do serviço público, portanto, na sua condição de existencial relativamente à sociedade" (LIMA, 1987:83, "passim").
} 
em 2010; e ADI no 3.994/DF, Pleno, Rel. Min. Carlos Britto, julgada em 2010), André Luiz Freire apontou a ausência de critério único, no STF, para definir serviços públicos (FREIRE, 2014:228-237). Salientou Freire, a partir da amostra por ele utilizada, que abrangeu decisões no controle concentrado de constitucionalidade (e, por isso, com efeito vinculante e eficácia contra todos), que o STF "não utiliza um critério para definir serviço público. Na motivação dos julgados - e outros poderiam ter sido aqui citados - a definição de serviço público tem sido utilizada de forma tópica, apenas para resolver o problema concreto que se apresentou para a Corte", acrescentando que "as concepções sobre serviço público também variam conforme a posição de cada julgador" (FREIRE, 2014:237/238, “passim”).

Nessa toada, também Vitor Rhein Schirato, após fazer incursão pela jurisprudência do STF, conclui não ser possível “[...]extrair-se da jurisprudência do Supremo Tribunal Federal um conceito de serviço, nem tampouco uma uniformidade na definição de seu regime jurídico[...]" (SCHIRATO, 2012:73).

Inconsistente, assim, o recurso à alegada essencialidade do serviço de prevenção e extinção de incêndio para, com base nessa essencialidade, impedir a exigência de taxa de prevenção e combate a incêndio. A essencialidade não deve ser empregada, no âmbito jurídico, para distinguir o serviço público de outras prestações de serviço, na medida em que o critério não oferece a necessária segurança jurídica para se fazer quaisquer distinções.

Raciocinado por absurdo, averbe-se que, se o argumento adotado no Tema $\mathrm{n}^{\mathrm{o}} 16$ da Repercussão Geral fosse estendido para situações semelhantes, ter-se-ia o reconhecimento, por exemplo, da inconstitucionalidade da chamada "taxa judiciária", cujo fato gerador é a prestação do "serviço judiciário". Não há negar, por certo, a natureza "essencial” da função jurisdicional, até por ser o acesso à Jurisdição uma garantia constitucional (art. $5^{\circ}$, inciso XXXV, da CR/1988). Todavia, nunca se negou, por essa razão, a natureza jurídica de taxa da contraprestação exigida pela prestação desse serviço judiciário.

Realmente, o STF reconhece, desde pelo menos a Representação (REP) n n 1.077/RJ, Pleno, Rel. Min. Moreira Alves (BRASIL, 1984), que a "taxa judiciária é tributo da espécie taxa", fazendo ampla remissão à doutrina, processualista e tributarista, e rejeitando a tese de que, por ser essencial, o serviço judiciário haveria de ser remunerado por meio da receita de impostos. Destaque-se, especialmente, a seguinte passagem do acórdão na REP nº 1.077/RJ, na qual se descreveu a polêmica em torno da caracterização jurídica da "taxa judiciária" como taxa ou imposto: 
Aliás, é conhecida na Itália a discussão de que participaram, entre outros, EINAUDI, CARNELUTTI e SATTA, sobre a natureza e a justificação das despesas processuais sob o ângulo do direito tributário. EINAUDI a sustentar que, sendo a justiça função essencial do Estado, com vistas à defesa nacional e à segurança publica, serve ela não somente aos litigantes, mas a todos os cidadãos; e suas despesas, por isso, deveriam ser atendidas por impostos judiciários (imposta giudiciaria) suportados por todos e não por taxas (tasse) que recairiam sobre os litigantes. CARNELUTTI a defender a imposição de taxas judiciárias, por considerar que a concepção publicística do processo não conduz à tese de EINAUDI, pois o Estado, à semelhança do que ocorre quando trata dos doentes, deve cobrar também taxas dos litigantes pelo serviço público de composição das lides. E SATTA - em artigo cujo título é bastante expressivo: Riflessi tributari della teoria generale del processo (Rivista del Diritto Commerciale, vol. 36, parte I, págs. 192 e segs.) - a assumir posição intermediária: parte das despesas com o Judiciário deveria caber a todos, por meio de impostos; a outra parte, porém, aos litigantes, por intermédio de taxas [...] (BRASIL, 1984:50-51).

Assim, desde a Emenda Constitucional no 18, de 1965, pelo menos, o STF concluiu que a "taxa judiciária" tem, inapelavelmente, a natureza jurídica de taxa, entendimento este referendando por grande número de autores, vários deles citados pelo Min. Moreira Alves:

Depois da Emenda Constitucional n ${ }^{\circ} 18 / 65$, cujo critério de distinção entre imposto e taxa foi seguido pela atual Constituição, e, em face,também, da nova redação dada ao artigo $8^{\circ}$, XVII, letra "c", dessa mesma Constituição pela Emenda Constitucional no $7 / 77$, não pode haver duvida de que taxa judiciária é taxa remuneratória. [...]

Processualistas e tributaristas não hesitam, nesses diversos países, em capitular as despesas processuais de correntes das contribuições obrigatórias impostas aos litigantes pelo Estado para atender aos ônus financeiros com o Poder Judiciário como sendo tributo da espécie taxa. [...]

No Brasil, o panorama, entre processualistas e tributaristas, não é diverso. FREDERICO MARQUES (Manual de Direito Processual Civil, vol. III, nº 715, pág. 270, Saraiva, São Paulo, 1975), aludindo a custas no sentido empregado pelo C.P.C. de 1974, o qual abarca a taxa judiciária, acentua: "As custas constituem matéria de direito tributário, visto que são devidas à Fazenda Pública ou ao serventuário da Justiça, como remuneração pelos serviços prestados aos litigantes" [... $]^{8}$.

Essa orientação continua a ser seguida - e ainda com mais razão em face da definição constitucional de taxa - na vigência da atual Constituição. Assim, BALEEIRO (Direito Tributário Brasileiro, 10a. ed. , págs. 330/331, Forense, Rio de Janeiro, 1981), ao acentuar que a taxa cabe quando os serviços recebidos pelo contribuintes resultam de função específica do Estado, ato de autoridade, que por sua natureza repugna ao desempenho do particular e não pode ser objeto de concessão a este, citando, como exemplo de serviços dessa natureza, os "serviços públicos de justiça"; THEODORO NASCIMENTO (Tratado de Direito Tributário Brasileiro, vol. VII - Preços, Taxas e Parafiscalidade - , págs. 113/114, Forense, Rio de Janeiro, 1977) arrola entre as taxas exigidas pela utilização de serviços a "taxa judiciária, paga pela utilização dos serviços que compõem o Poder Judiciário (serviços da Justiça)", e acentua que essa taxa continua a ser taxa apesar de cobrada com a denominação de"custas judiciais, emolumentos do Juízo". RUI BARBOSA NOGUEIRA (Curso de Direito Tributário, 5a. ed., pág. 164, Saraiva, São Paulo, 1980) acentua, ao tratar dos requisitos das taxas, que "serviço específico é aquele que somente pode ser prestado pelo Estado, isto é, serviço administrativo ou JURISDICIONAL", e arremata: "Só ao Estado compete prestá-lo aos seus jurisdicionados como desempenho de atribuições públicas e como decorrência do jus imperii"; e LOURENÇO DOS SANTOS (Direito Tributário, 4a.ed., pág. 61, Fundação Getúlio Vargas, Rio de Janeiro,1970) inclui entre as taxas

${ }^{8}$ O Min. Moreira Alves ainda citou, entre outros, Arruda Alvim, Humberto Theodoro Júnior, Miguel Lins, Célio Loureiro, Castro Nunes, Amílcar de Araújo Falcão, mas, por brevidade, fez-se a transcrição parcial. 
as "taxas judiciárias". (BRASIL, 1984:48, 52, 54/55, "passim") (BRASIL, 1984: 4854, "passim").

Também na vigência da atual CR/1988, não houve alteração no entendimento do STF, que continuou a atribuir à "taxa judiciária" a natureza jurídica de taxa, nunca de imposto", entendimento que não mais se sustentaria, caso se estendesse a tese firmada no Tema $n^{\circ} 16$ da Repercussão Geral ao serviço judiciário, tão essencial quanto o serviço de combate e prevenção a incêndio.

Em realidade, no Direito Tributário, a invocação da eventual "essencialidade" do serviço público, como bem anotou Roberto Ferraz, ora é usada para justificar a instituição da taxa (como no caso da taxa judiciária), ora é, imprecisamente, invocada justamente para afastar a possibilidade de instituição da taxa (em uma hipótese, por exemplo, de taxa de segurança interna):

No entanto, não é difícil sustentar que a segurança interna é igualmente inerente à soberania do Estado, sendo, porém, nesse caso, mais facilmente concebível sua divisibilidade, donde se pode concluir que seria compatível a cobrança de taxas pela segurança, por policiamento específico, referido ao contribuinte.

Frequentemente essa hipótese é apontada como inconcebível, reputando-se obrigatório o custeio da atividade policial por meio dos impostos, ora com fundamento em sua indivisibilidade, ora com fundamento diverso: o de sua absoluta essencialidade, o que afastaria a cobrança de taxas (FERRAZ, 2013: 88-89).

Após demonstrar essa paradoxal ambivalência da invocação da "essencialidade" do serviço público, aqui para negar a possibilidade de taxa, ali para afirmar a imperatividade dela, Roberto Ferraz arrematou que o "recurso à 'essencialidade" deve ser utilizado para afirmar a necessidade da exigência de taxa, e não de tarifa (ou preço público) ${ }^{10}$, quando houver manifestação de "atividade soberana do Estado":

\footnotetext{
${ }^{9} \mathrm{Na}$ jurisprudência posterior à vigente $\mathrm{CR} / 1988$, podem ser apontados, como exemplos, dentre outros precedentes, a ADI ${ }^{\circ}$ 1.145/PB, Pleno, Rel. Min. Carlos Velloso, julgada em 2002; a MC na ADI $n^{\circ}$ 2.040/PR, Pleno, Rel. Min. Maurício Corrêa, julgada em 1999; e a ADI nº 948/GO, Pleno, Rel. Min. Francisco Rezek, 1995. Salientese, porém, que o STF também afirma que "as custas dos serviços forenses se dividem em taxa judiciária e custas em sentido estrito", abrangendo neste último conceito, a "despesa com porte de remessa e retorno", eximindo as entidades públicas de arcarem com essas despesas (Tema $n^{\circ} 135$ da Repercussão Geral, objeto do RE $n^{\circ}$ 594.116/SP, Pleno Rel. Min. Edson Fachin, julgado em 03.dez.2015).

${ }^{10}$ Não há uniformidade no emprego dos termos "tarifa" e "preço público". Hely Lopes Meirelles os emprega como sinônimos (MEIRELLES, 1991:342), da mesma forma que Dinorá Adelaide Musetti Grotti (GROTTI, 2003:231 232), enquanto Celso Antônio Bandeira de Mello opta pelo termo "tarifa" (BANDEIRA DE MELLO, 2009:728), assim como André Luiz Freire (FREIRE, 2014:362). Também o STF emprega "tarifa" como sinônimo de "preço público" (por exemplo, AgRg. no Ag.Rg. no RE nº 600.237-SP, 2 ${ }^{\mathrm{a}}$ Turma, Rel. Min. Dias Toffoli, julgado em 17.mar.2015). No presente trabalho, a questão não ganha relevância, razão pela qual se as expressões são empregadas como sinônimos, optando-se por tarifa, apenas por questão de uniformidade.
} 
Levantou-se essa curiosa questão para demonstrar que o mesmo argumento que serve para sustentar a natureza da taxa (essencialidade do serviço público prestado) tem servido também para sustentar a absoluta impossibilidade de imposição de taxa (dada a "absoluta" essencialidade da atividade).

Portanto, o recurso à "essencialidade" como nota característica das taxas há de ser tomado com cuidado, bem explicitando o que se pretende dizer. Entende-se aqui que essa essencialidade é a inerência à atividade soberana do Estado, que se manifesta como poder (de polícia ou de obrigar determinado serviço, exigindo seu pagamento pela simples disponibilidade, independentemente de efetiva fruição) (FERRAZ, 2013:89).

Com efeito, na sempre polêmica e difícil distinção entre taxa e tarifa, a essencialidade é mais comumente utilizada para afirmar, em franca oposição à tese firmada no Tema ${ }^{\circ} 16$ da Repercussão Geral, que a "remuneração" pela prestação do serviço público se faça por via da taxa. Nesse sentido, assinalou Alcides Jorge Costa, a propósito da distinção entre taxa e tarifa, que "serviços essenciais, como os de justiça, compreendem-se no campo das taxas, enquanto os serviços industriais dizem respeito a preço" (COSTA, 1985:5-6). Ainda nesse mesmo sentido, Toshio Mukai (MUKAI, 1985:246).

Todavia, se a essencialidade é, por vezes, invocada para afirmar a necessidade de se exigir taxa (e não tarifa) como contraprestação pelo serviço público prestado, não se pode dizer que, no nosso Direito Tributário, predomine esse critério como elemento de distinção. É bem verdade, como registrou Jacintho Arruda Câmara, que existe "[...] um grande desconforto de parte da doutrina e da própria jurisprudência em reconhecer a existência de um forte traço de discricionariedade na competência legislativa para determinar o regime jurídico a ser aplicado à forma de contraprestação [...]" dos usuários do serviço público, isto é, se taxa, ou tarifa (CÂMARA, 2009:40). Desse modo, prossegue Arruda Câmara, ainda “[...] não foi apresentado, em qualquer das teses, um limite material, inerente à própria natureza do serviço, que sirva de critério absoluto para adoção de um ou outro sistema" (CÂMARA, 2009:41).

Apesar desse desconforto a que alude Jacintho Arruda Câmara, ele próprio reconhece que o tradicional critério adotado pelo STF para fazer a distinção entre taxa e tarifa, qual seja, a obrigatoriedade do uso do serviço público, conquanto não seja critério inequestionável (até porque objeto de disceptação no próprio STF), ainda se afigura como o critério mais seguro:

Entendemos, porém, que, apesar da indefinição jurisprudencial a respeito das conseqüências que a obrigatoriedade de um serviço público acarreta, o regime jurídico constitucional condiciona a aplicação dessa característica (a obrigatoriedade) à cobrança efetuada sob o rigor do sistema tributário Isto é, os serviços considerados obrigatórios pela legislação só podem ser remunerados mediante taxa (CÂMARA, 2009:44). 
Esse critério - obrigatoriedade do serviço público - foi adotado em 1980, pelo STF, ao julgar o RE no 89.876/RJ, Pleno, Rel. Min. Moreira Alves, julgado em 04.set.1980, cuja ementa é a seguinte:

Tarifa Básica de Limpeza Urbana.

- Em face das restrições constitucionais a que se sujeita a instituição de taxa não pode o Poder Público estabelecer, a seu arbítrio, que à prestação de serviço público específico e divisível corresponde contrapartida sob a forma, indiferentemente, de taxa ou de preço público.

- Sendo compulsória a utilização do serviço público de remoção de lixo - o que resulta, inclusivo, de sua disciplina como serviço essencial à saúde pública -, a tarifa de lixo instituída pelo Decreto $\mathrm{n}^{\circ} 295$, de 12 de novembro de 1975, do poder Executivo do Município do Rio de Janeiro, é, em verdade, taxa.

- Inconstitucionalidade do referido decreto, uma vez que taxa está sujeita ao princípio constitucional da reserva legal. Recurso extraordinário conhecido e provido (BRASIL, 1980).

Portanto, o STF reconhece que os serviços públicos específicos e divisíveis podem ser remunerados por via da taxa ou da tarifa, mas, em se tratando de serviços de utilização compulsória, somente a taxa seria exigível. Diversos tributaristas compartilham desse entendimento, como Luís Eduardo Schoueri (SCHOUERI, 2017:198), Hugo de Brito Machado (MACHADO, 2017:446-447), Ives Gandra da Silva Martins (MARTINS, 1985:176), Gilberto de Ulhôa Canto (CANTO, 1985:105) e Ricardo Lobo Torres (TORRES, 2013:407), embora Ricardo Lobo Torres tenha advertido que, em sua opinião, a "compulsoriedade do uso há que se restringir ao serviço público essencial de utilização obrigatória, sendo uma conseqüência da essencialidade, e não uma premissa para a construção do conceito de serviço público" (TORRES, 2013:407) ${ }^{11}$.

Portanto, em vez de se empregar a essencialidade do serviço como requisito para se afastar a exigência da taxa, é muito mais comum, no direito tributário brasileiro, se invocar essa essencialidade para afirmar a compulsoriedade no uso do serviço público, a resultar na

\footnotetext{
${ }^{11}$ Não há espaço neste trabalho, e não é objetivo dele, esmiuçar as discussões em torno do conceito de taxa, notadamente em contraposição ao de tarifa. Registre-se, porém, de passagem, a existência de ao menos duas outras correntes doutrinárias. Uma delas, na qual se inserem Marco Aurélio Greco e Hamilton Dias de Souza (GRECO; SOUZA, 1985:126-127), tem em Geraldo Ataliba seu mais conhecido defensor, e afirma que a contraprestação pelo serviço público deverá ser, sempre, a taxa (ATALIBA, 1998:145-150). Outra corrente, na qual pontifica Sacha Calmon Navarro Coêlho, rejeita a utilidade de critérios apriorísticos, afirmando que o "dilema resolve-se pela opção do legislador", aplicando-se à taxa ou à tarifa o regime jurídico correspondente (COÊLHO, 2010:400). Antônio Carlos Diniz Murta, em trabalho apresentado ao XV Congresso Nacional do CONPEDI, também rejeitou critérios "a priori", especialmente eventual "essencialidade" do serviço, afirmando que "a via remuneratória dos denominados serviços públicos, será, em algumas hipóteses a taxa (especialmente, por imposição, quando o serviço for prestado por pessoa jurídica de direito público) e, em outras hipóteses, será o preço público, especialmente por opção político-administrativa, na atração de capital privado e consecução de lucro do próprio Estado-empresário" (MURTA, 2006:326). Há muitas outras variações teóricas em torno do tema, mas elas se mostram irrelevantes para a discussão, porquanto nenhuma delas corroboraria o entendimento firmado no Tema $\mathrm{n}^{\mathrm{o}} 16$ da Repercussão Geral, fazendo-se esse registro apenas por dever de lealdade acadêmica.
} 
imposição da taxa (com possibilidade de sua exigência pela mera disposição do serviço, e não por sua efetiva utilização). Assim, ao recorrer, no julgamento do Tema $\mathrm{n}^{\mathrm{o}} 16$ da Repercussão Geral, à essencialidade do serviço de extinção e combate a incêndios, o STF adotou critério que discrepou de reiterada orientação da própria Corte e da doutrina, tornando questionável a exigência de outras taxas cujos fatos geradores envolvam, também, a prestação de serviços públicos essenciais, sendo o exemplo mais destacado a mencionada "taxa judiciária". Sob a ótica que prevaleceu no Tema $\mathrm{n}^{\mathrm{o}} 16$ da Repercussão Geral, a "taxa judiciária" não mais subsistiria, assim como quaisquer outras taxas cujos fatos geradores possam ser enquadrados na ideia de serviços essenciais. Torna-se evidente, dessa maneira, o desacerto da tese afirmada pelo STF no aludido Tema $\mathrm{n}^{\circ} 16$.

Noutro compasso, por também afirmar que serviços essenciais deveriam ser custeados pela receita de impostos, o STF agravou seu equívoco, adotando critério de distinção entre a taxa e o imposto que remonta aos primórdios do direito tributário. Enfático, Geraldo Ataliba assinalou ser "[...]absurdo, despropositado, anticientífico, ilógico e primário recorrer a argumento ligado ao destino que o estado dá aos dinheiros arrecadados para disso pretende extrair qualquer conseqüência válida em termos de determinação da natureza específica dos tributos" (ATALIBA, 1998:139).

Também Paulo de Barros Carvalho salientou que a regra legal segundo a qual é irrelevante para definir a "natureza jurídica específica do tributo [...] a destinação legal do produto de sua arrecadação" (inciso II do art. $4^{\circ}$ do CTN), contém "um aviso providencial: o destino que se dê ao produto da arrecadação é irrelevante para caracterizar a natureza jurídica do tributo" (CARVALHO, 2017:60). Essa regra, acrescentou Paulo de Barros Carvalho, traça os limites do próprio direito tributário, "que não se ocupa dos momentos ulteriores à extinção do liame fiscal" (CARVALHO, 2017:60). Por essa razão, Paulo de Barros Carvalho igualmente rechaçou "lições doutrinária que salientam a particularidade de o produto da arrecadação dos impostos convergir para as despesas gerais do Estado, sem o menor resquício de contraprestação" (CARVALHO, 2017:64). Essa concepção, que segundo Barros Carvalho poderia ter alguma utilidade para a ciência das finanças, "nada acrescentam ao estudo do Direito Tributário" (CARVALHO, 2017:65).

Veja-se que Luís Eduardo Schoueri, embora igualmente tenha afirmado a irrelevância da destinação dos recursos, observou que a regra contida no art. $4^{\circ}$, inciso II, do CTN, somente alcança as espécies tributárias clássicas, quais sejam, imposto, taxa e contribuição de melhoria (SCHOUERI, 2017:179). Essa regra já não se aplicaria, porém, ao empréstimo compulsório e à contribuição já não seria possível afirmar a irrelevância da "destinação legal do produto de 
sua arrecadação" (SCHOUERI, 2017:180). Ora, o Tema nº 16 da Repercussão Geral cuidou, justamente, de taxa, de modo que a vinculação das despesas com o serviço de combate a incêndio e a "arrecadação de impostos" é retroceder a mais de cinquenta anos em termos teóricos.

É importante ressaltar que a Constituição da República também não corrobora o raciocínio adotado no referido Tema $\mathrm{n}^{\mathrm{o}} 16$, cabendo lembrar que a Emenda Constitucional $\mathrm{n}^{\mathrm{o}}$ 45, de 8 de dezembro de 2004, acrescentou o§ $2^{\circ}$ ao art. 98 da CR/1988. Segundo esse dispositivo constitucional, "custas e emolumentos serão destinados exclusivamente ao custeio dos serviços afetos às atividades específicas da Justiça". Essas custas e emolumentos, como já visto, compreendem a já mencionada "taxa judiciária", de modo que a Constituição da República, não apenas reconhece que serviço público "essencial” pode se constituir em fato gerador da taxa, como também é possível vincular a receita dessa taxa ao custeio do serviço que lhe é fato gerador.

Em suma, afirmar que os gastos com o serviço público de prevenção e combate a incêndio, porque essenciais, deveriam ser custeados pela receita de impostos é recorrer a critério empregado na Ciência das Finanças, que pouco contribui no campo estritamente jurídico. Notadamente porque o sistema jurídico tributário brasileiro, a par de tornar irrelevante a destinação dos recursos arrecadados para fins de configuração de taxa ou imposto, ainda vincula a receita da taxa judiciária à satisfação das despesas com esse serviço público, inegavelmente essencial. Logo, fragiliza-se a sustentação teórica da tese afirmada no Tema $\mathrm{n}^{\mathrm{o}} 16$ da Repercussão Geral, contribuindo-se para suscitar maior insegurança jurídica, em razão da radical alteração no entendimento tradicionalmente adotado pelo STF.

\section{Conclusão}

A argumentação desenvolvida ao longo do presente artigo permite, agora, ao final da exposição, firmar a conclusão de que o Tema $n^{0} 16$ da Repercussão Geral, ao afirmar a inconstitucionalidade da taxa de prevenção e combate a incêndio, o fez de forma equivocada.

Embora a questão não tenha sido aprofundada no presente trabalho, foi constatado que não obteve a maioria absoluta dos votos dos Ministros do STF a afirmação de não ser possível definir como fato gerador da taxa aqueles serviços públicos havidos como essenciais. Basicamente, somente o Relator, Min. Marco Aurélio, adotou essa linha de argumentação, enquanto o Min. Roberto Barros, que formou ao lado da maioria, apenas acolheu argumento de índole formal (incompetência dos Municípios para prestar o serviço de combate e prevenção a 
incêndios). Os demais quatro Ministros do STF, que compuseram a maioria, em realidade, se fiaram no argumento de que o serviço público de prevenção e combate a incêndio não seria específico e divisível, não podendo ser definido, por isso, como fato gerador da taxa.

E, inegavelmente, não se deveria recorrer ao conceito de serviço público essencial para validar, ou não, a exigência de taxa, em primeiro lugar, porque a ideia de essencialidade é extremamente controvertida e cambiante. Em segundo lugar, porque a Constituição da República optou por vincular a exigência de taxa pela prestação de serviços públicos à especificidade e à divisibilidade dos serviços, não cogitando de essencialidade desses serviços. E, em terceiro lugar, a contraposição entre taxa e tarifa considera, basicamente, a obrigatoriedade, ou não, do serviço público para afirmar a necessidade de se remunerar tal serviço público (obrigatório) por meio da taxa, sendo a essencialidade dos serviços públicos, no mais das vezes, invocada para apontar a obrigatoriedade do próprio serviço público, a resultar na adoção da taxa.

Também equivocado se mostrou o recurso à origem dos recursos para, eventualmente, se afastar a constitucionalidade da taxa pela prestação de serviço público de prevenção e combate a incêndio. $\mathrm{O}$ sistema tributário brasileiro, há mais de cinquenta anos, abandonou o critério da destinação de recursos para distinguir a taxa do imposto (e ainda da contribuição de melhoria), não se justificando o retorno a esse superado critério.

Por fim, se dúvidas há sobre a especificidade e a divisibilidade da taxa pela prestação de serviço público de prevenção e combate a incêndio, essa deveria ser a linha argumentativa seguida pelos cinco Ministros que concluíram pela inconstitucionalidade material da taxa em questão, visto que específicos e divisíveis são os atributos que a CR/1988 estabelece para a legítima exigência da taxa pela prestação de serviço público. A inovação, principalmente, da essencialidade do serviço público destoa do texto constitucional, fragiliza a fundamentação jurídica do Tema ${ }^{\circ} 16$ da Repercussão Geral, contribuindo para a insegurança jurídica em torno da exigência do tributo em exame.

\section{Referências bibliográficas}

\section{AGUILLAR, Fernando Herren. Serviços públicos - Doutrina, jurisprudência e legislação.}

São Paulo: Saraiva, 2011.

ATALIBA, Geraldo. Hipótese de incidência tributária. 5 ed. 7 tiragem. São Paulo:

Malheiros, 1998. 
BANDEIRA DE MELLO, Celso Antônio. Curso de direito administrativo. 26 ed. São Paulo: Malheiros, 2009.

BRASIL. Supremo Tribunal Federal. Recurso Extraordinário no 643.247 - São Paulo. Relator: Ministro Marco Aurélio. Pesquisa de Jurisprudência, Acórdãos, 19 dezembro 2017.

Disponível em: < http://www.stf.jus.br/portal/jurisprudencia/pesquisarJurisprudencia.asp >. Acesso em: 10 jan. 2018.

BRASIL. Supremo Tribunal Federal. Representação no 1.077 - Rio de Janeiro. Relator: Ministro Moreira Alves. Pesquisa de Jurisprudência, Acórdãos, 28 setembro 1984. Disponível em: < http://www.stf.jus.br/portal/jurisprudencia/pesquisarJurisprudencia.asp >. Acesso em: 28 fev. 2018.

BRASIL. Supremo Tribunal Federal. Recurso Extraordinário nº 89.876 - Rio de Janeiro. Relator: Ministro Moreira Alves. Pesquisa de Jurisprudência, Acórdãos, 04 setembro 1980. Disponível em: < http://www.stf.jus.br/portal/jurisprudencia/pesquisarJurisprudencia.asp >. Acesso em: 26 mar. 2018.

CÂMARA, Jacintho Arruda. Tarifa nas concessões. São Paulo: Malheiros, 2009.

CANTO, Gilberto de Ulhôa. Taxa de preço público. In: Caderno de pesquisas tributárias Taxa e preço público. MARTINS, Ives Gandra da Silva (coordenador). São Paulo: Centro de Estudos de Extensão Universitária e Editora Resenha Tributária, 1985, p. 83-110.

CARVALHO, Paulo de Barros. Curso de direito tributário. 28 ed. São Paulo: Saraiva, 2017.

COÊLHO, Sacha Calmon Navarro. Curso de direito tributário brasileiro. 11 ed. Rio de Janeiro: Forense, 2010.

COSTA, Alcides Jorge. Taxa e preço público. In: Caderno de pesquisas tributárias - Taxa e preço público. MARTINS, Ives Gandra da Silva (coordenador). São Paulo: Centro de Estudos de Extensão Universitária e Editora Resenha Tributária, 1985, p. 1-6. 
GRECO, Marco Aurélio; SOUZA, Hamilton Dias. Taxa e preço. In: Caderno de pesquisas tributárias - Taxa e preço público. MARTINS, Ives Gandra da Silva (coordenador). São Paulo: Centro de Estudos de Extensão Universitária e Editora Resenha Tributária, 1985, p. 111-132.

GROTTI, Dinorá Adelaide Musetti. O serviço público e a Constituição brasileira de 1988. São Paulo: Malheiros, 2003.

GUSTIN, Miracy B. S.; DIAS, Maria Tereza Fonseca. (Re)pensando a pesquisa jurídica. 2 ed. Belo Horizonte: Del Rey, 2006.

LIMA, Ruy Cirne. Princípios de direito administrativo. 6 ed. São Paulo: Revista dos Tribunais, 1987.

MACHADO, Hugo de Brito. Curso de direito tributário. 38 ed. São Paulo: Malheiros, 2017.

MARTINS, Ives Gandra da Silva. Taxa e preço público. In: Caderno de pesquisas tributárias - Taxa e preço público. MARTINS, Ives Gandra da Silva (coordenador). São Paulo: Centro de Estudos de Extensão Universitária e Editora Resenha Tributária, 1985, p. 153-186.

MEDINA, José Miguel Garcia. Prequestionamento, repercussão geral da questão constitucional, relevância da questão federal - Admissibilidade, processamento e julgamentos dos recursos extraordinário e especial. 7 ed. São Paulo: Revista dos Tribunais, 2017.

MEIRELLES, Hely Lopes. Direito administrativo brasileiro. 16 ed. São Paulo: Revista dos Tribunais, 1989.

MUKAI, Toshio. Taxa e preço público. In: Caderno de pesquisas tributárias - Taxa e preço público. MARTINS, Ives Gandra da Silva (coordenador). São Paulo: Centro de Estudos de Extensão Universitária e Editora Resenha Tributária, 1985, p. 239-250. 
MURTA, Antônio Carlos Diniz. Considerações sobre as taxas e tarifas: opção ou imposição como remuneração na contra-prestação do serviço público. In: Anais do XV Congresso Nacional do CONPEDI: Direito, sociobiodiversidade e soberania na Amazônia, 2006, Manaus. Anais do XV Congresso Nacional do CONPEDI. Florianópolis: Fundação Boiteux, 2006. v. 1. p. 315-339.

SCHOUERI, Luís Eduardo. Direito tributário. 7 ed. São Paulo: Saraiva, 2017.

SCHIRATO, Vitor Rhein. Livre iniciativa nos serviços públicos. Belo Horizonte: Fórum 2012.

TORRES, Ricardo Lobo. Curso de direito financeiro e tributário. 19 ed. Rio de Janeiro: Renovar, 2013. 


\title{
O EQUILÍBRIO NA POLÍTICA DE DISTRIBUIÇÃO DE DIVIDENDOS NAS EMPRESAS ESTATAIS
}

\author{
Gabriel Senra da Cunha Pereira \\ Pontifícia Universidade Católica de Minas Gerais
}

Edimur Ferreira de Faria

Pontifícia Universidade Católica de Minas Gerais

\section{Resumo}

Este trabalho visa a identificar os limites da distribuição de dividendos das empresas estatais ao Estado controlador. Primeiramente, far-se-á uma evolução histórica das empresas estatais no Brasil e se abordará como elas desempenham suas funções sociais. Em seguida, examinarse-á o lucro como elemento essencial ao atingimento da função social e, depois, como receita patrimonial do Estado. Por fim, defender-se-á o equilíbrio na distribuição dos dividendos das empresas públicas e sociedades de economia mista ao controlador. A metodologia do trabalho consiste em pesquisa empírica de dados obtidos diretamente dos órgãos do Estado, consulta bibliográfica e à legislação que abrange o tema.

Palavras-chave: Empresas Estatais, Função social, Dividendos, Distribuição, Equilíbrio.

\begin{abstract}
Resumen/Résumé
This work aims to identify dividend distribution limits of state-owned companies to the controlling State. First, there will be a historical evolution of the state-owned enterprises in Brazil and will discuss how they perform social functions. Next, profit will be examined as an essential element in the attainment of the social function and as the state's revenue. Finally, a balance will be defended in the distribution of the dividends of state-owned companies to the controlling shareholder. The methodology consists of empirical research of data obtained from the organs of the State, bibliographical consultation and the legislation that covers the subject.
\end{abstract}

Keywords/Palabras-claves/Mots-clés: State-owned Companies, Social function, Dividends, Distribution, Balance. 


\section{Introdução}

As empresas estatais passam por forte crise de credibilidade no Brasil nos últimos anos, motivada principalmente, mas não só, pelos dois maiores escândalos de corrupção recente do país: o primeiro ocorrido em 2005, em que a Empresa Brasileira de Correios e Telégrafos (CORREIOS) foi protagonista; o segundo, em 2014, que envolveu a maior estatal brasileira, a Petróleo Brasileiro S.A. (PETROBRAS).

O desequilíbrio fiscal e a recessão econômica que o Brasil enfrenta desde 2014 abalaram também a estrutura financeira das empresas públicas e sociedades de economia mista de todas as esferas de governo.

A crise de identidade das empresas estatais, há algum tempo alertada por Mario Engler Pinto Junior (2013), motivou o surgimento da Lei Federal n. 13.303, de 30 de junho de 2016 (BRASIL, 2016), que, embora dezoito anos atrasada, atendeu ao mandamento estabelecido no art. 173, § $1^{\circ}$, da Constituição da República de 1988 (CR/1988) (BRASIL, 1988), acrescido ao texto pela Emenda Constitucional n. 19, de 04 de junho de 1998 (BRASIL, 1998).

Alguns dos principais objetivos da nova lei são reduzir ao máximo a influência política na indicação de diretores e conselheiros (OLIVEIRA, 2016) e impor regras de governança e transparência na gestão das empresas públicas e sociedades de economia mista (AMARAL, 2016).

Também como consequência dos abalos políticos, mas principalmente econômicofinanceiros vividos no Brasil, vê-se a retomada do movimento de "privatização" das empresas estatais $^{1}$, cuja primeira "onda" teve seu ápice na década de 1990. Além disso, a necessidade de capitalização do Estado brasileiro motivou, nos últimos anos, uma intensa distribuição dos dividendos das empresas públicas e sociedades de economia mista, colocando em risco a continuidade das atividades de algumas dessas pessoas jurídicas.

Esse contexto político e econômico impõe que seja repensado qual é o efetivo papel das empresas estatais brasileiras e de que modo elas devem contribuir para o alcance dos objetivos fundamentais da República, insculpidos no art. $3^{\circ}$ da CR/1988.

Dentro desse quadro, pretende-se, neste artigo, investigar a função do lucro das empresas estatais tanto em relação ao controlador quanto em relação às finalidades públicas

\footnotetext{
${ }^{1}$ Em 23 de agosto de 2017, o Governo Federal anunciou plano de privatização de quatro empresas estatais, dentre as quais a Empresa Brasileira de Aeronáutica S/A (EMBRAER). (GOVERNO..., 2018). Em Minas Gerais, o Governo estadual iniciou as medidas necessárias à alienação de parte da Companhia de Desenvolvimento de Minas Gerais (CODEMIG). (DINIZ; PIZZARO, 2018).
} 
para as quais elas foram criadas. Primeiramente, serão estudados os objetivos das empresas estatais, a partir da análise de sua evolução histórica e função social. Em seguida, passar-se-á à análise da função que o lucro desempenha nas companhias e a importância dos dividendos como receita patrimonial do Estado. Por fim, pretender-se-á esclarecer a necessidade do equilíbrio na distribuição dos dividendos das empresas estatais ao ente controlador, a fim de se assegurar o cumprimento integral das funções para as quais elas foram criadas e também preservar a receita financeira do Estado.

As perguntas que se pretendem responder por meio deste trabalho são: qual é o papel do lucro das empresas públicas e sociedades de economia mista? Ele tem alguma função além da remuneração do ente controlador? Há limites à distribuição dos dividendos das empresas estatais? Como equilibrar a função social das empresas estatais com a necessidade de obtenção de receitas do Estado na qualidade de sócio ou acionista controlador?

Pretende-se responder a essas questões a partir da concepção da existência de uma resposta correta como limitação da discricionariedade administrativa. Utilizar-se-á, ainda, a consulta à bibliografia, jurisprudência e legislação aplicável à matéria, especialmente à CR/1988 e à Lei n. 13.303/2016. O método será o dedutivo.

\section{Os objetivos e a função social das empresas estatais}

Visando a facilitar a compreensão deste item e primando por melhor didática, o texto seguinte será dividido em dois subitens.

\subsection{Evolução histórica}

O Estado brasileiro iniciou sua experiência empresarial por meio de instituições financeiras. O Banco do Brasil foi criado pelo então Príncipe Regente, D. João VI, pelo Alvará de 12 de outubro de 1808 (BRASIL, 1808), sob a forma de sociedade por ações. Embora o Banco estivesse sob o controle da Coroa portuguesa, o art. V do primeiro Estatuto da instituição permitia a participação de toda e qualquer pessoa, nacional ou estrangeira, na sua composição acionária ${ }^{2}$.

\footnotetext{
2 “Art. V. É indifferente serem, ou não os accionistas nacionaes ou estrangeiros; e portanto toda e qualquer pessoa, que quizer entrar para a formação deste corpo moral o poderá fazer sem exclusão alguma, ficando unicamente obrigada a responder pela sua entrada." (BRASIL, 1808).
} 
Já em 1861, D. Pedro II instituiu, por meio do Decreto n. 2.723, de 12 de janeiro de 1861 (BRASIL, 1861), uma Caixa Econômica, que tinha por finalidade "receber a juro de 6\%, as pequenas economias das classes menos abastadas, e de assegurar, sob garantia do Governo Imperial, a fiel restituição do que pertencer a cada contribuinte" quando este o reclamasse. Naquela época, a Caixa Econômica não possuía a feição empresarial atual, mas exercia a função social de guarda das poupanças individuais com a garantia do Governo Imperial.

A Caixa Econômica, originariamente entidade autárquica, só veio a assumir a feição de empresa pública e a adotar a sua denominação atual (Caixa Econômica Federal) em 1969, por intermédio do Decreto-Lei n. 759, de 12 de agosto de 1969 (BRASIL, 1969b), quando passou a assumir outras funções além daquela primordialmente estabelecida, inclusive a concessão de empréstimos e financiamentos de natureza assistencial.

Mas, a criação dessas duas instituições financeiras no Século XIX não representou o início da intervenção do Estado no domínio econômico de forma sistêmica; tal forma de atuação estatal só passou a ocorrer a partir da década de 40. A Constituição brasileira de 1937 (BRASIL, 1937), marcada pelo intervencionismo do Estado Novo, reconheceu no art. 135 que cabia à iniciativa privada o papel primário da geração de riquezas e prosperidade, mas estabeleceu que o Estado poderia intervir na economia, em caráter subsidiário, "para suprir as deficiências da iniciativa individual e coordenar os fatores da produção, de maneira a evitar ou resolver os seus conflitos e introduzir no jogo das competições individuais o pensamento dos interesses da Nação, representados pelo Estado".

Se antes o Estado brasileiro criara sua primeira empresa estatal no setor financeiro, agora, com Getúlio Vargas (1930-1945 e 1951-1954), os setores escolhidos foram o siderúrgico e minerário, petrolífero e elétrico ${ }^{3}$. Conforme esclarece Mario Engler Pinto Junior (2013, p. 20), o viés ideológico dominante à época entendia como essencial o desenvolvimento da indústria de base "como forma de conquistar a emancipação do país em face dos interesses externos"

Ademais, aqueles eram espaços ainda não ocupados pela iniciativa privada nacional, preponderantemente agropecuária, de modo que o Estado buscou criar um ambiente favorável

\footnotetext{
${ }^{3}$ Nesse contexto surgiram a Companhia Siderúrgica Nacional (CSN) pelo Decreto-Lei n. 3.002, de 30 de janeiro de 1941 (BRASIL, 1941), a Companhia Vale do Rio Doce S.A., pelo Decreto-Lei n. 4.352, de $1^{\circ}$ de junho de 1942 (BRASIL, 1942), e a Petróleo Brasileiro S.A. (Petrobrás) foi constituída pela Lei Federal n. 2.004, de 3 de outubro de 1953 (BRASIL, 1953). O Projeto de Lei n. 4.280 (BRASIL, 1954), de criação da Centrais Elétricas Brasileiras S.A. (Eletrobrás), foi enviado ao Congresso Nacional por Getúlio Vargas em abril de 1954, mas só foi aprovada a sua criação em 1961, pela Lei Federal n. 3.890-A, de 25 de abril de 1961 (BRASIL, 1961).

${ }^{4}$ Apesar do discurso emancipatório, Mario Engler Pinto Junior (2013) lembra que o impulso para a criação do parque industrial nacional ocorreu com o Acordo de Washington, pelo qual os Estados Unidos comprometeramse a fornecer equipamentos e recursos financeiros necessários à implantação das novas empresas estatais e, em contrapartida, o Brasil supriria o governo norte-americano com o minério de ferro extraído, ratificando ainda o apoio ao esforço de guerra dos aliados.
} 
ao desenvolvimento de outros empreendimentos privados em diversos setores dependentes da indústria de base.

Em mensagem encaminhada ao Congresso Nacional em 1954, Getúlio Vargas defendeu essa estratégia dizendo: "Uma economia como a nossa, até há pouco preponderantemente agropecuária, cujas dificuldades de crescimento eram vencidas no próprio processo de produção, saltou bruscamente para a industrialização acelerada" (BRASIL, 1954a, p. 9). A empresa estatal desempenhou, dessa forma, um papel estratégico na economia brasileira, tendo se transformado no principal motor da industrialização nacional (PINTO JUNIOR, 2013).

Em 1967, a Administração Pública passou por uma reforma administrativa, com ênfase ao aprimoramento do Estado empresário e empregador. Essa reforma veio com a edição do Decreto-Lei n. 200, de 25 de fevereiro de 1967 (BRASIL, 1967). O art. $5^{\circ}$ desse normativo define as entidades integrantes da Administração indireta: autarquia, empresa pública, sociedade de economia mista e fundação pública. Nessa época, o perfil da intervenção do Estado brasileiro no domínio econômico deslocou-se da indústria de base para o setor tecnologia, justificada não apenas pelo setor estratégico da área no mundo moderno, mas também pelo apelo militar de defesa nacional, viés ideológico do governo da época ${ }^{5}$.

Manteve-se, pois, o modelo intervencionista do Estado brasileiro no domínio econômico, especialmente até meados da década de 70, de tal forma que as empresas estatais já se faziam presentes nos setores financeiro, de siderurgia e mineração, energético, petrolífero, de transportes, petroquímico, de química pesada, aeronáutico, nuclear e tecnológico. O Estado brasileiro tornou-se maior, mais pesado e mais caro.

Porém, os desequilíbrios fiscais e a crise econômica enfrentada pelo Brasil a partir de 1976 frearam o movimento expansionista do setor empresarial público brasileiro. A necessidade dos ajustes econômico-financeiros do Estado retirou o caráter eminentemente estratégico das estatais, para transformá-las em instrumento de política macroeconômica (PINTO JUNIOR, 2013). Passou-se a utilizar as estatais como instrumentos de arrecadação.

Esse movimento intensificou-se também em solo europeu. A partir da década de 1980, o governo britânico iniciou agressivo movimento de privatização visando a reduzir drasticamente o papel do Estado na economia, o que se deu nos setores aeronáutico, telecomunicações, energia, aeroportuário e saneamento (AMPARO; CALMON, 2000).

\footnotetext{
${ }^{5}$ Essa conjuntura político-econômica ensejou a criação de empresas como a Empresa Brasileira de Aeronáutica S.A. (EMBRAER), pelo Decreto-Lei n. 770, de 19 de agosto de 1969 (BRASIL, 1969c), e a Empresas Nucleares Brasileiras S.A. (NUCLEBRÁS), pela Lei n. 6.189, de 16 de dezembro de 1974 (BRASIL, 1974).
} 
O desenvolvimento tecnológico, por sua vez, abriu a possibilidade de competição em setores antes monopolizados pelo Estado, o que fez reduzir a dependência dos consumidores aos bens e serviços por este produzidos (PINTO JUNIOR, 2013).

Dessa forma, o movimento de privatizações ganhou força também na América Latina, onde instituições como o Banco Mundial e o Fundo Monetário Internacional passaram a exercer forte influência, principalmente com a queda dos regimes socialistas soviéticos. O Consenso de Washington, como ficou conhecida essa conjuntura política internacional na América Latina, desencadeou diversas mudanças no cenário até então prevalecente, dentre as quais, no Brasil, destaca-se o Programa Nacional de Desestatização (PND), instituído pela Lei Federal n. 8.031, de 12 de abril de 1990 (BRASIL, 1990), editada no contexto de profunda reforma do aparelho do Estado, com foco na privatização das empresas estatais, ressalvadas as consideradas, naquela época, essenciais, como Banco do Brasil, Caixa Econômica Federal, Petrobrás, Eletrobrás, Eletronuclear e Correios. Entre os objetivos do Programa, encontrava-se a redução da dívida pública, a fim de sanear as combalidas finanças estatais, conforme estabeleceu o art. $1^{\circ}$, inc. II, do Programa.

Iniciou-se assim a venda de grandes empresas estatais, o que contribuiu para o influxo de capitais no Brasil e a estabilização econômica em meados da década de 90, a partir da reformulação da visão sobre o papel do Estado na economia. Houve migração do foco da atuação estatal: do intervencionismo para a regulação.

A crença no livre mercado regulado, contudo, sofreu fortes abalos com a crise econômica desencadeada nos Estados Unidos em 2008, o que forçou o governo norteamericano adotar medidas intervencionistas, com o aporte de 700 bilhões de dólares aos bancos daquele país, tornando-se o Estado norte-americano acionista das instituições beneficiadas (TESOURO..., 2008). Tal acontecimento marcou a retomada do papel estratégico do Estado no domínio econômico (PINTO JUNIOR, 2013).

Vê-se que ao longo do tempo o Estado interveio na economia, ora para utilizar as empresas estatais como instrumentos de realização de políticas públicas estratégicas, ora como forma de arrecadação para o equilíbrio das contas públicas em tempos de crise. No Brasil, apesar do movimento de privatização experimentado a partir do PND, o Estado ainda detém forte presença na economia, por meio de grandes empresas petrolíferas, instituições financeiras, de geração, transmissão e distribuição de energia elétrica, e também prestadoras de serviços públicos, como os Correios ${ }^{6}$.

\footnotetext{
${ }^{6}$ Os CORREIOS foram transformados em empresa pública pelo Decreto-Lei n. 509, de 20 de março de 1969 (BRASIL, 1969a).
} 
No contexto atual, em que o Estado brasileiro enfrenta grave crise fiscal, cuja dívida bruta do Governo Geral supera 75\% do Produto Interno Bruto (PIB) (INDICADORES..., 2018), observa-se novo e forte movimento arrecadatório por meio das estatais, seja com as privatizações $^{7}$, seja com a política de distribuição de dividendos, em alguns casos em prejuízo da própria função para a qual a empresa pública ou sociedade de economia mista foi criada. É sobre isso que se tratará a seguir.

\subsection{A função social das empresas estatais}

Nenhuma empresa possui um fim em si mesma. Sejam elas públicas ou privadas, as corporações têm caráter instrumental, pois destinam-se à satisfação de interesses de pessoas humanas, estas sim dotadas de valor intrínseco ${ }^{8}$.

As empresas privadas têm por finalidade precípua a obtenção do lucro e a geração de riqueza. Como consequência do alcance de seu objetivo principal, exercem o que se denomina "função social das empresas".

Segundo Mayara Gasparoto Tonin (2016), a ideia da função social das empresas está inserida em contexto de funcionalização do próprio Direito. A lógica liberalista, de que as normas são estruturas meramente formais, foi superada com o advento do Estado Social. Os institutos jurídicos passaram a possuir funções, com vistas ao alcance material de determinados objetivos sociais.

No ordenamento jurídico brasileiro, os objetivos fundamentais da República estão insculpidos no art. $3^{\circ}$ da CR/1988. A partir desses objetivos, a própria Constituição definiu contornos mais claros da função social da empresa, como se pode ver no art. 170. O dispositivo expõe a existência digna como finalidade a ser alcançada pelo exercício de qualquer atividade econômica e fixa os princípios a serem observados, dentre os quais a função social da propriedade, a defesa do consumidor e do meio ambiente, a redução das desigualdades e a busca do pleno emprego.

\footnotetext{
7 Tramita no Congresso Nacional, desde 22/1/2018, o Projeto de Lei n. 9.463/2018, que dispõe sobre a desestatização da Eletrobrás (BRASIL, 2018c). Em Minas Gerais, a Assembleia Legislativa aprovou a Lei Estadual n. 22.828, de 3 de janeiro de 2018, que aprova a transformação da empresa pública Companhia de Desenvolvimento Econômico de Minas Gerais (CODEMIG) em sociedade de economia mista, com a finalidade de desestatização (MINAS GERAIS, 2018).

${ }^{8}$ Sobre o valor intrínseco da pessoa humana, vide: (SARMENTO, 2016).
} 
Nas palavras de Mayara Gasparoto Tonin (2016, p. 270-271), “Assim, a empresa terá cumprido sua função social quando seu exercício obedecer a esses princípios constitucionais, que passam a nortear a atividade empresarial.”.

$\mathrm{Na}$ legislação infraconstitucional também se identificam textos que tratam da função social da empresa, como o art. 116, parágrafo único, e o art. 154, ambos da Lei Federal n. 6.404, de 15 de dezembro de 1976 (Lei das S/A) (BRASIL, 1976). Este último dispositivo, aliás, estabelece que o administrador da empresa deve exercer as atribuições que lhe são conferidas pela lei e pelo estatuto, para lograr os fins e no interesse da companhia, observada a função social da empresa.

Dessa forma, a função social não pode ser exigida para além daquelas atividades e finalidades específicas para a qual a organização foi fundada. É por meio do exercício das atividades finalísticas que a empresa exerce a sua função social, valorizando o trabalho humano e a livre iniciativa, respeitando os direitos do consumidor e o meio ambiente, contribuindo para a redução das desigualdades e a busca do pleno emprego.

Por isso é que se disse, no princípio deste tópico, que é por meio do alcance da sua finalidade precípua (obtenção de lucro e geração de riqueza) que a empresa privada exerce a sua função social, como consequência da primeira função para a qual ela foi criada.

No caso das estatais, as prioridades se invertem. A finalidade primeira das empresas públicas ou sociedades de economia mista será sempre o atendimento do interesse público. $\mathrm{O}$ lucro pode até ser buscado pelas estatais, desde que como instrumento ao alcance dos objetivos de interesse coletivo (VANELLI, 2016). Nos dizeres de Luís Roberto Barroso (2005):

\footnotetext{
Nas empresas estatais, a affectio societatis, peculiar à sociedade privada (comunhão de vontades individuais dirigida a um precípuo fim lucrativo) cede passo a um objetivo de utilidade pública, embora de teor econômico. A sociedade privada, nada obstante a função social da empresa; é voltada para o acionista. A empresa pública e particularmente a sociedade de economia mista - devendo também considerar os interesses dos acionistas, é voltada para o usuário, ou seja, para a comunidade. (BARROSO, 2005, p. 86)
}

O conteúdo da função social das empresas estatais está no art. 173 da CR/1988, segundo o qual a exploração direta de atividade econômica pelo Estado somente será permitida para atender aos imperativos da segurança nacional ou a relevante interesse coletivo, que para Mario Engler Pinto Junior (2013) são fatores de legitimidade do empreendimento estatal. A recente Lei n. 13.303/2016 prevê, em seu art. 27, exatamente as mesmas expressões como conteúdo da função social a que as estatais se destinam a cumprir. Cabe ao legislador ordinário expressar de modo concreto quais são esses pressupostos jurídicos para a criação do 
empreendimento estatal, conforme se extrai da parte final dos art. 173 da CR/1988 e 27 da Lei n. $13.303 / 2016$.

De forma ainda mais expressa, o art. $8^{\circ}$ da Lei n. 13.303/2016 prevê, nos incisos I e V, a obrigatoriedade de as empresas públicas e sociedades de economia mista explicitarem os compromissos de consecução dos objetivos de políticas públicas e adotarem política de distribuição de dividendos à luz da função social que justificou suas criações.

Em suma, até aqui se viu que as empresas privadas têm como fim primário a obtenção de lucro e a geração de riqueza, para atender às necessidades e desejos humanos, mas exercem, nos limites e por meio de suas atividades-fim, a função social que lhes é imposta constitucionalmente.

Inversamente, a finalidade precípua das empresas estatais é o exercício de sua função social, que consiste no atendimento de relevante interesse coletivo ou imperativo da segurança nacional. Delimita-se, pois, que nos empreendimentos do Estado, o lucro pode até funcionar como instrumento de alcance dessas finalidades, justificando medidas de sua maximização ou minimização, mas não como intento último. A função dos lucros das empresas públicas e sociedades de economia mista é o que será estudado no item seguinte.

\section{O lucro nas empresas estatais}

Viu-se nos itens anteriores que o interesse público está presente no princípio (momento da criação) e na finalidade das empresas do Estado. O relevante interesse coletivo ou os imperativos da segurança nacional devem ser explicitados concretamente no ato legislativo que autoriza a instituição das estatais, nos seus estatutos e, ainda, nas medidas de transparência estabelecidas no art. $8^{\circ}$ da Lei n. 13.303/2016.

Há, contudo, importante reflexão que deve ser feita sobre o conceito de interesse público. Segundo Celso Antônio Bandeira de Mello (2015, p. 66), a expressão "interesse público" comporta dois sentidos distintos: um significando o interesse da coletividade, que ele chama de "dimensão pública dos interesses individuais"; outro significando o interesse individual do Estado, os quais se equiparariam aos interesses de qualquer outro indivíduo. A primeira dimensão, denomina interesse público primário; a segunda, interesse público secundário, pois ainda que em primeiro plano haja um interesse individual do Estado, no pano de fundo trata-se de instrumento ao atingimento do interesse público primário. (MELLO, 2015).

Essa distinção é de grande valia ao presente trabalho, na medida em que, conforme Mario Engler Pinto Junior (2013, p. 232), “somente o interesse público primário pode ser 
equiparado ao interesse coletivo inscrito no art. 173 da CR/1988 e, portanto, encampado como missão da empresa estatal".

Sob a ótica do interesse público primário buscado pelas estatais, o lucro exerce função instrumental, porque não só representa a saúde e a capacidade econômico-financeira da corporação, como lhe oferece liquidez e capitalização suficientes para o melhor e mais eficiente exercício da missão institucional que lhe foi confiada.

Mas não se pode desconsiderar a existência e a importância do interesse público secundário, consistente na pretensão do Estado de obter receitas para fazer frente às suas despesas, principalmente em momentos de crise. Trata-se o lucro também de receita patrimonial do Estado, que exerce papel de inegável importância às finanças públicas, que, ao fim e ao cabo, destinam-se a atender às demandas da sociedade.

A grande questão que se pretende enfrentar neste artigo, portanto, começa a se descortinar. Trata-se do conflito ${ }^{9}$ evidente, principalmente em tempos de crise econômica e financeira, entre essas duas dimensões do interesse público: até que ponto o órgão controlador pode absorver os lucros das suas controladas para reequilibrar suas finanças sem prejudicar os objetivos das estatais, que, como visto, encerram exatamente o interesse público da coletividade em si, motivo primeiro e último de sua criação.

\subsection{O lucro como elemento essencial ao exercício da função social das empresas estatais}

Para os fins deste artigo, o termo "lucro" deve ser entendido como mera diferença positiva entre as receitas e as despesas da empresa em certo espaço de tempo. Pouco importa para este estudo estabelecer diferenças, por exemplo, entre lucro bruto, líquido, contábil e econômico. Também serão tratados como sinônimos "superávit"10, "saldo positivo" e assemelhados. Como bem alertado por Jacintho Arruda Câmara (2012), trata-se de questão que não interfere nos objetivos deste estudo, mas serviria apenas para desviar-se do foco proposto.

Conforme se falou no tópico anterior, o lucro é a finalidade primeira das empresas privadas, enquanto que nas empresas estatais serve de instrumento ao alcance do interesse público primário ou secundário. Neste ensaio, quando se fala do lucro como ferramenta de

\footnotetext{
9 Para Mario Engler Pinto Junior (2013, p. 232), “o interesse secundário teria natureza instrumental e sua preservação constitui normalmente requisito para o bom atendimento do interesse primário, o qual deve sempre prevalecer na hipótese de confronto entre ambos."

${ }^{10}$ Segundo Geraldo Ataliba e José Artur Lima Gonçalves (1995, p. 354), empresas estatais prestadoras de serviços públicos não têm lucro ou prejuízo, mas superávit ou déficit. Para o autor, "confundir superávit com lucro é afrontar as diretrizes e princípios constitucionais e legais informadores do nosso direito positivo", o assim como o superávit seria mera consequência do exercício da atividade da empresa estatal.
} 
atendimento ao interesse público primário, fala-se da sua importância para o exercício da função social das estatais. Quando se fala do superávit como instrumento de obtenção do interesse público secundário, fala-se dele como receita patrimonial do Estado, ente controlador da empresa estatal. Neste tópico, especificamente, está-se a tratar da primeira hipótese.

Alguns autores ${ }^{11}$ defendem que as empresas estatais não devem ter como objetivo o lucro, principalmente aquelas que se destinam à prestação de serviços públicos. Essa ideia parte da premissa de que o Estado, ainda que por meio das estatais, não pode ter por finalidade aumentar seu patrimônio ou enriquecer-se pura e simplesmente. O objetivo deve ser, sempre, o interesse público. Assim, admite-se até mesmo que as empresas estatais sejam deficitárias. Ademais, segundo expõe Jacintho Arruda Câmara (2012), outra premissa desse raciocínio é a de que "a obtenção de lucro seria obviamente um interesse [público] secundário não podendo, como tal, ser buscado pela Administração (no caso, pela empresa estatal)".

Ditas premissas, entretanto, não levam à conclusão de que as estatais não podem objetivar o lucro, pois o raciocínio deixa de considerar papel importantíssimo que o lucro exerce, que vai muito além do mero enriquecimento ou do interesse público secundário: assegurar a liquidez, o financiamento e a expansão da própria atividade da empresa, e ainda viabilizar a captação de recursos para a alavancagem de suas operações.

Isso significa que a obtenção e, mais ainda, a preservação do lucro das estatais serve não só para financiar a atividade do próprio Estado controlador (interesse público secundário), mas também e, principalmente, para permitir o adequado exercício da atividade da própria empresa, o que significa dizer que ele serve justamente como ferramenta ao exercício da função social para a qual foi criada. Nas palavras de Jacintho Arruda Câmara (2012):

\begin{abstract}
Muito pelo contrário, na maioria das vezes, a lucratividade da empresa constitui instrumento fundamental para a realização da atividade de interesse público com uma maior eficiência. E é justamente essa busca do lucro, em prol da realização do interesse público, que constitui uma das principais justificativas para a opção pelo modelo empresarial na Administração Pública.

Como empresa, a obtenção de superávit financeiro nas atividades desenvolvidas pode ser mais eficientemente alocada na realização de seu fim. O lucro serve para autofinanciar a ampliação das atividades da empresa, bem como para viabilizar a obtenção de recursos junto a instituições financeiras. (CÂMARA, 2012, p. 3).
\end{abstract}

Ora, uma vez que o Estado deliberou por criar a empresa pública ou a sociedade de economia mista, o fez ciente de que a instituição-terá a forma empresarial, sujeitando-se a

\footnotetext{
${ }^{11}$ Além de Geraldo Ataliba e José Artur Lima Gonçalves (1995) e Jacintho Arruda Câmara (2012) demonstra que também defendem tal posição: Eros Grau, Carlos Ari Sundfeld, Seabra Fagundes e Ricardo Marcondes Martins.
} 
regime jurídico semelhante ao do setor privado $^{12}$ (art. 173, $\S 1^{\circ}$, da CR/1988), setor esse que, como visto, tem o lucro como finalidade precípua.

Daí que a compreensão de que o lucro das estatais é incompatível com o alcance do interesse público primário não parece adequada. O lucro exerce, sim, função de elevada importância à efetivação da função social para a qual a organização empresarial do Estado foi criada.

Para ilustrar o que ora se defende e contrapor ainda mais o argumento de que as estatais (inclusive prestadoras de serviços públicos em regime de monopólio) não podem objetivar lucro, traz-se o exemplo recente dos Correios. Trata-se de empresa pública controlada pela União e, nos termos do art. $4^{\circ}, \S 3^{\circ}$ de seu Estatuto Social, é obrigada, no exercício de sua função social, "a assegurar a continuidade dos serviços postais e telegráficos, observados os índices de confiabilidade, qualidade, eficiência” (EMPRESA BRASILEIRA DE CORREIOS E TELÉGRAFOS, 2018)

Em outubro de 2017, o Ministério da Transparência e Controladoria-Geral da União elaborou o Relatório n. 201700921 (BRASIL, 2017a), para avaliar a situação econômica e financeira da ECT no período compreendido entre 2011 e 2016. O aludido trabalho foi realizado em razão dos contínuos prejuízos contábeis que vinham sendo apurados desde 2013, e seu objetivo foi detectar os principais fatos que originaram essa situação deficitária.

Não se pretende aqui esmiuçar os números apresentados no Relatório, mas apenas utilizar algumas das informações dele constantes para demonstrar, na prática, os efeitos nefastos que a política que desconsidera a importância dos lucros pode causar à função social da empresa.

Conforme o estudo do órgão federal, especialmente a partir do ano de 2013 a empresa pública apontada apresentou "crescente degradação em sua capacidade de pagamento no longo prazo (liquidez), aumento do endividamento e da dependência de capitais de terceiros, e principalmente redução drástica de sua rentabilidade” (BRASIL, 2017 a, p. 8).

As principais causas apontadas foram a transferência elevada de recursos para a União (entidade controladora) entre 2011 e 2013, o que impactou negativamente na capacidade de investimento da empresa, e o aumento exponencial de despesas com pessoal.

\footnotetext{
${ }^{12}$ Com este mesmo argumento, defendemos, em artigo intitulado "O regime jurídico das empresas estatais sob a ótica da lei n. 13.303/2016: aspectos gerais, específicos e polêmicos" (PEREIRA; FARIA, 2017), que as empresas estatais prestadoras de serviços públicos também sujeitam-se às normas da Lei Federal n. 13.303/2016. Mais recentemente, o Supremo Tribunal Federal decidiu, no Recurso Extraordinário 851.711/DF, que mesmo as empresas públicas prestadoras de serviços públicos em regime de monopólio não se sujeitam ao regime de precatórios estabelecido no art. $100 \mathrm{da} \mathrm{CR} / 1988$, equiparando-as, neste aspecto, às pessoas jurídicas de Direito Privado (BRASIL, 2017b).
} 
Quanto à primeira causa, que é o objeto deste artigo, verifica-se que entre 2011 e 2013, a empresa pública teve um lucro líquido acumulado de $\mathrm{R} \$ 1.841 .600 .000,00$ (um bilhão oitocentos e quarenta e um milhões e seiscentos milhões de reais), mas foram pagos à União dividendos na ordem de $\mathrm{R} \$ 2.969 .000 .000,00$ (dois bilhões novecentos e sessenta e nove milhões de reais), dos quais mais de um bilhão se referiram a adiantamentos.

A apropriação da totalidade dos lucros da empresa pelo órgão controlador reduziu "drasticamente a capacidade de investimento da empresa, e consequentemente, a sua viabilidade econômica financeira" (BRASIL, 2017 a, p. 45). A crise financeira agravou-se a tal ponto que, sem a injeção de recursos por parte do controlador, a ECT sujeita-se à insolvência, tornando-se dependente ${ }^{13}$ dos recursos orçamentários da União para exercer suas atividades e perdendo autossuficiência.

Isso significou, na prática, considerável piora na prestação dos serviços públicos postais e telegráficos. As dificuldades financeiras impuseram a estagnação das carreiras e redução de custos com o seu pessoal, o que levou os trabalhadores da estatal a declararem greve em meados de março de 2018 (FUNCIONÁRIOS..., 2007).

No ano de 2016 foram feitas 32.249 reclamações por consumidores contra a empresa. Em 2017, este número subiu para 41.014, aumento superior a $27 \%$ de um ano para o outro. E, no período entre 1/4/2017 e 31/3/2018, as reclamações totalizam 55.429, 35\% a mais que em 2017 e quase $72 \%$ a mais que em 2016. (RECLAME AQUI, 2017).

É nítido, portanto, que o comprometimento dos lucros da empresa estatal, mesmo sendo ela prestadora de serviços públicos em regime de monopólio, como os Correios, gera consequências nefastas para o exercício de sua função social e causa prejuízos ao próprio interesse público que motivou sua criação. Por isso, alia-se ao seguinte entendimento de Mario Engler Pinto Junior:

\begin{abstract}
O que não faz sentido é a empresa estatal adotar política agressiva de distribuição de dividendos (ou pagamento de juros sobre o capital próprio), acima do mínimo obrigatório, sob pena de limitar sua capacidade de autofinanciamento. O pagamento de dividendos com o fito apenas de remunerar o investimento acionário estatal contribui para a descapitalização da companhia e significa desvirtuamento de propósitos. A empresa estatal não deve ser vista exclusivamente como instrumento de geração de receitas para reforçar o caixa do tesouro (enquanto único acionista ou acionista majoritário), nem tampouco para enriquecer acionistas privados além da taxa de retorno considerada razoável para remunerar o custo do capital próprio, segundo padrões usuais de mercado. (PINTO JUNIOR, 2013, p. 363)
\end{abstract}

\footnotetext{
${ }^{13}$ Conforme o art. $2^{\circ}$, inc. III, da Lei Complementar 101, de 4 de maio de 2000, considera-se empresa estatal dependente a "empresa controlada que receba do ente controlador recursos financeiros para pagamento de despesas com pessoal ou de custeio em geral ou de capital, excluídos, no último caso, aqueles provenientes de aumento de participação acionária". (BRASIL, 2000).
} 
Desse modo, muito embora se entenda que os lucros exerçam papel instrumental e não finalístico nas empresas estatais, eles são essenciais ao atingimento e efetivação das funções sociais que ensejaram a sua criação e motivam a continuidade de sua existência.

Isso não significa, porém, que o Estado deve prescindir de receber os resultados positivos que a companhia apresentar. Este é o tema do tópico seguinte.

\subsection{A importância dos dividendos como receita patrimonial do Estado}

No tópico anterior abordou-se a essencialidade dos lucros para o desempenho da função social das empresas estatais, o que se equiparou ao interesse público primário. Não se pode olvidar, por outro lado, da importância da distribuição dos dividendos ao Estado controlador como fonte de receitas para o financiamento das suas atividades.

A CR/1988 estabelece que todas as esferas de governo devem ser prover serviços públicos aos indivíduos e à sociedade, que passam pela saúde, educação, previdência social, cultura, desporto, entre outras (ABRAHAM, 2017). Ao se atribuir direitos ao indivíduo ou à coletividade, a Constituição, em inúmeros casos, atribuiu ao Estado o dever de garanti-los. Citem-se, como exemplos, o art. 196 e o art. 205, que prescrevem que a saúde e a educação são direito de todos e dever do Estado.

Para fazer frente a todas essas tarefas constitucionais obrigatórias, o Estado precisa arrecadar recursos. Não mais se admite mais que os governos arrecadem recursos por meio da força física, com extorsão, dominação de povos, escravização e o confisco indiscriminado de bens, como faziam os Estados autoritários da antiguidade e da modernidade ${ }^{14}$. Em tempos atuais, para financiar-se, o Estado tem as seguintes alternativas: a) obter rendas produzidas por meio da exploração de seu patrimônio; b) exigir compulsoriamente a prestação pecuniária dos cidadãos, como os tributos e multas; c) tomar empréstimos; ou d) fabricar dinheiro (ABRAHAM, 2017) $)^{15}$.

De fato, as receitas tributárias são a maior parte da arrecadação do Estado, representando aproximadamente $87 \%$ das receitas correntes previstas pela União Federal na Lei Orçamentária Anual de 2018 (Lei Federal n. 13.587, de 2 de janeiro de 2018) (BRASIL, 2018a).

\footnotetext{
${ }^{14}$ Sobre os meios de arrecadação de recursos pela violência utilizados pelo Estado, leia-se (OLIVEIRA, 2014).

${ }^{15}$ Este estudo trata da obtenção de rendas advindas do próprio patrimônio estatal, que são suas empresas públicas e sociedades de economia mista, receita que se classifica como patrimonial na Lei Federal n. 4.320, de 17 de março de 1964 (BRASIL, 1964).
} 
Mas elas, sozinhas, não são suficientes para fazer frente a todas as despesas a que o Estado está obrigado.

Já as receitas patrimoniais, onde se inclui a distribuição de dividendos, representam quase $6 \%$ de todas as receitas correntes da União previstas no orçamento de 2018.

Deve-se ressaltar que em 2011 a União arrecadou quase 30 bilhões de reais somente com a distribuição de dividendos das empresas estatais. (BRASIL, 2018b). Em 2012, o valor ultrapassou 39 bilhões. A partir daí, observou-se um processo de redução dessa receita, que foi de aproximadamente 23 bilhões de reais em 2013 e 2014, 13 bilhões em 2015, menos de 3 bilhões em 2016 e, em 2017, pouco mais de 5,5 bilhões de reais ${ }^{16}$.

Observa-se, portanto, que a distribuição de lucros e dividendos das empresas estatais é significativa fonte de receitas estatais, não devendo ser desprezada. Trata-se de importante instrumento para o equilíbrio fiscal e, também, para a atividade financeira do Estado, cujos recursos totais são bastante escassos em relação às obrigações que lhe foram atribuídas pela $\mathrm{CR} / 1988$.

Se o Estado eventualmente optasse por abrir mão dos dividendos distribuídos pelas suas empresas públicas e sociedades de economia mista, deveria compensar essa perda por outros meios, como o aumento da já elevada carga tributária ou a tomada de novos empréstimos, o que elevaria ainda mais a também altíssima dívida pública brasileira.

Desse modo, resta evidente que o lucro exerce papel importante para não só para o alcance do interesse público primário das estatais, o qual se traduz na função social para a qual foi criada, mas também para o interesse público secundário, já que o Estado necessita da arrecadação de recursos para desenvolver suas atividades precípuas e, se não o fizer pela distribuição de dividendos das estatais, o fará por meios mais onerosos à sociedade.

Daí que se impõe equilíbrio na distribuição de dividendos das empresas estatais, de modo que, de um lado, se preserve a saúde financeira e a capacidade de investimento das companhias e, de outro, se ofereça ao ente público controlador os recursos necessários à sua atividade.

\section{Conclusão}

O início da experiência brasileira com as empresas estatais não encontrou motivação na obtenção de lucros ou na distribuição de dividendos ao ente controlador. Em meados do

\footnotetext{
${ }^{16}$ Estes valores não levam em consideração a arrecadação com distribuição de dividendos aos Estados, Distrito Federal e Municípios.
} 
século passado, quando o Estado brasileiro assumiu feição interventora, as estatais atuaram em setores estratégicos da economia.

Mas o desenvolvimento tecnológico e o fenômeno da globalização abriram espaços para a concorrência em setores que antes eram dominados pelo Estado interventor. Além disso, as intensas crises econômicas e financeiras pelas quais o Brasil passou nas últimas décadas do século passado contribuíram para o deslocamento da função das estatais: do fomento e ocupação de setores estratégicos da economia para importante fonte de receita do Estado, seja pelos processos de desestatização, seja pela elevada distribuição de dividendos ao controlador.

O lucro passou de coadjuvante a protagonista. Muito se passou a discutir sobre a legitimidade de sua busca e as funções que ele deveria desempenhar no âmbito das empresas estatais. Se na iniciativa privada o lucro é o objetivo principal e a função social da empresa se realiza a partir dele, nas estatais o interesse público é a finalidade precípua, e o lucro exerce, quanto a estas, papel instrumental.

Mesmo nas empresas públicas prestadoras de serviços públicos em regime de monopólio, o lucro tem caráter de essencialidade, pois confere liquidez, capacidade de investimento para a expansão e aprimoramento de suas atividades, e permite a obtenção de crédito em condições vantajosas. Tudo isso se traduz no melhor desempenho da companhia estatal.

A experiência brasileira mostra que a excessiva distribuição de dividendos para elevar os ingressos financeiros ao ente controlador desidrata e precariza a empresa estatal, prejudicando, ao cabo, o alcance da função social para a qual foi criada, aqui tratada como interesse público primário.

De outro lado, não se pode negar a importância dos dividendos como receita patrimonial do Estado, que tem muitas atribuições obrigatórias delegadas pela CR/1988. As receitas tributárias não são, por si sós, suficientes para cobrir as despesas estatais e garantir o equilíbrio fiscal. A receita patrimonial do Estado, como interesse público secundário, não pode ser desconsiderada, pois funciona como meio para o atingimento dos objetivos fundamentais da República estabelecidos no art. $3^{\circ}$ da CR/1988.

É necessário que haja, portanto, equilíbrio na política de distribuição de dividendos das empresas estatais aos entes controladores, de modo a se garantir os ingressos financeiros estatais simultaneamente em que se busca garantir a preservação de parte dos lucros no caixa das companhias, para bem exercer seus misteres.

O Estado controlador deve obter o máximo de receita com o mínimo de sacrifício da estatal controlada. A empresa pública e a sociedade de economia mista devem preservar ao 
máximo os seus lucros, nos limites de seus estatutos, com o mínimo de sacrifício das receitas patrimoniais do controlador.

Assim, do ponto de vista do Estado, o limite da distribuição de dividendos deve ser o máximo até o ponto em que não prejudique a capacidade econômica e financeira da empresa controlada. Do ponto de vista da empresa estatal, a distribuição limita-se ao mínimo possível, capaz de garantir o melhor exercício da atividade financeira do Estado.

É do confronto entre essas duas visões - o máximo é o mínimo e o mínimo é o máximo - que surgirá a resposta correta, consistente no exato montante a ser distribuído pelas empresas estatais aos seus entes controladores.

\section{Referências bibliográficas}

ABRAHAM, Marcus. Curso de direito financeiro brasileiro. 4. ed. rev. atual. e ampl. Rio de Janeiro: Forense, 2017.

AMARAL, Paulo Osternack. Lei das Estatais: espectro de incidência e regras de governança. In: JUSTEN FILHO, Marçal (Org.). Estatuto jurídico das empresas estatais. São Paulo: Revista dos Tribunais, 2016. p. 59-70.

AMPARO, Paulo Pitanga do; CALMON, Katya Maria Nasiaseni. A experiência britânica do setor saneamento. Brasília: IPEA, 2000. Disponível em:

$<$ http://ipea.gov.br/agencia/images/stories/PDFs/TDs/td_0701.pdf $>$. Acesso em 7.4.2018.

ATALIBA, Geraldo; GONÇALVES, José Artur Lima. Empresa estatal delegada de serviço público tem superávit ou déficit (não é devedora da contribuição social sobre o lucro). [S. 1.]: FGV, 1995. Disponível em: $<$ http://bibliotecadigital.fgv.br/ojs/index.php/rda/article/download/46561/46584>. Acesso em: 18 abr. 2018.

BARROSO, Luís Roberto. Regime jurídico das empresas estatais. Revista de Direito Administrativo - RDA, Rio de Janeiro, 2005, v. 242, p. 85-94. Disponível em: $<$ http://bibliotecadigital.fgv.br/ojs/index.php/rda/issue/view/2475>. Acesso em 14 abr. 2018.

BRASIL. Alvará de 12 de outubro de 1808. Crêa um Banco Nacional nesta Capital. Collecção das leis do Brazil. Disponível em: 
$<$ http://bd.camara.gov.br/bd/bitstream/handle/bdcamara/18319/colleccao_leis_1808_parte1.pd f? sequence $=4>$. Acesso em: 7 abr. 2018.

\section{BRASIL. Avaliação da Situação Econômica e Financeira ECT - Empresa Brasileira de}

Correios e Telégrafos, exercícios 2011-2016, Relatório n. 201700921. Brasília: Ministério da Transparência e Controladoria-Geral da União, 2017a. Disponível em: $<$ https://auditoria.cgu.gov.br/download/10370.pdf>. Acesso em 18.4.2018.

BRASIL. Constituição da República Federativa do Brasil de 1988. Brasília: Senado, 1988. Nós, representantes do povo brasileiro, reunidos em Assembléia Nacional Constituinte para instituir um Estado Democrático, destinado a assegurar o exercício dos direitos sociais e individuais (...). Diário Oficial da União, Brasília, 5 out. 1988. Disponível em: $<$ http://www.planalto.gov.br/ccivil_03/Constituicao/Constituicao.htm>. Acesso em: $30 \mathrm{abr}$. 2018.

BRASIL. Constituição dos Estados Unidos do Brasil. Rio de Janeiro, 1937. O PRESIDENTE DA REPÚBLICA DOS ESTADOS UNIDOS DO BRASIL, ATENDENDO às legitimas aspirações do povo brasileiro à paz política e social, profundamente perturbada por conhecidos fatores de desordem (...). Diário Oficial da União, Rio de Janeiro, 10 nov. 1937. Disponível em: <http://www.planalto.gov.br/ccivil_03/constituicao/constituicao37.htm>. Acesso em: 30 abr. 2018.

BRASIL. Decreto n. 2.723, de 12 de janeiro de 1861. Autorisa a creação de uma Caixa Economica e um Monte de Soccorro nesta Côrte, e approva os respectivos Regulamentos. Coleção de Leis do Império do Brasil, Rio de Janeiro, 1861, p. 11 v. 1. Disponível em: $<$ http://www2.camara.leg.br/legin/fed/decret/1824-1899/decreto-2723-12-janeiro-1861556013-publicacaooriginal-75580-pe.html>. Acesso em 30 abr. 2018.

BRASIL. Decreto-Lei n. 200, de 25 de fevereiro de 1967. Dispõe sôbre a organização da Administração Federal, estabelece diretrizes para a Reforma Administrativa e dá outras providências. Diário Oficial da União, Brasília, 25 fev. 1967. Disponível em: $<$ http://www.planalto.gov.br/ccivil_03/decreto-lei/Del0200.htm>. Acesso em: 30.4.2018. 
BRASIL. Decreto-Lei n. 509, de 20 de março de 1969. Dispõe sobre a transformação do Departamento dos Correios e Telégrafos em empresa pública, e dá outras providências. Diário Oficial da União, Brasília, 21 mar. 1969a. Disponível em: <http:/www.planalto .gov.br/ccivil_03/decreto-lei/Del0509.htm>. Acesso em 3.5.2018.

BRASIL. Decreto-Lei n. 759, de 12 de agosto de 1969. Autoriza o Poder Executivo a constituir a emprêsa pública Caixa Econômica Federal e dá outras providências. Diário Oficial da União, Brasília, 12 ago. 1969b. Disponível em: <http://www.planalto .gov.br/ccivil_03/decreto-lei/Del0759.htm>. Acesso em: 7.4.2018.

BRASIL. Decreto-Lei n. 770, de 19 de agosto de 1969. Autoriza a União a constituir a EMBRAER - Emprêsa Brasileira de Aeronáutica S.A. e dá outras providências. Diário Oficial da União, Brasília, 27 ago. 1969c. Disponível em: <http://www.planalto .gov.br/ccivil_03/decreto-lei/1965-1988/Del0770.htm>. Acesso em 3.5.2018.

BRASIL. Decreto-Lei n. 3.002, de 30 de janeiro de 1941. Autoriza a constituição da Companhia Siderúrgica Nacional e dá outras providências. Diário Oficial da União, Rio de Janeiro, 1 fev. 1941. Disponível em <http://www2.camara.leg.br/legin/fed/declei/19401949/decreto-lei-3002-30-janeiro-1941-412984-publicacaooriginal-1-pe.html>. Acesso em: 3.5.2018.

BRASIL. Decreto-Lei n. 4.352, de $1^{\circ}$ de junho de 1942. Encampa as Companhias Brasileiras de Mineração e Siderurgia S.A. e Itabira de Mineração S.A. e dá outras providências. Diário Oficial da União, Rio de Janeiro, 3 jul. 1942. Disponível em <http://www2.camara. leg.br/legin/fed/declei/1940-1949/decreto-lei-4352-1-junho-1942-414669-republicacao68227-pe.html>. Acesso em: 3.5.2018.

BRASIL. Emenda Constitucional nº 19, de 4 de junho de 1998. Modifica o regime e dispõe sobre princípios e normas da Administração Pública, servidores e agentes políticos, controle de despesas e finanças públicas e custeio de atividades a cargo do Distrito Federal, e dá outras providências. Diário Oficial da União, Brasília, 5 jun. 1998. Disponível em: <http://www. planalto.gov.br/ccivil_03/Constituicao/Emendas/Emc/emc19.htm> Acesso em: 07 ago. 2017. 
BRASIL. Lei Complementar n. 101, de 4 de maio de 2000. Estabelece normas de finanças públicas voltadas para a responsabilidade na gestão fiscal e dá outras providências. Diário Oficial da União, Brasília, 5 mai. 2000. Disponível em: $<$ http://www.planalto. gov.br/ccivil_03/leis/lcp/lcp101.htm> Acesso em: 3 mai. 2018.

BRASIL. Lei Federal n. 2.004, de 3 de outubro de 1953. Dispõe sôbre a Política Nacional do Petróleo e define as atribuições do Conselho Nacional do Petróleo, institui a Sociedade Anônima, e dá outras providências. Diário Oficial da União, Brasília, 25 abr. 1961. Disponível em: <http:/www.planalto.gov.br/ccivil_03/leis/13890acons.htm> Acesso em: 3 mai. 2018.

BRASIL. Lei Federal n. 3.890-A, de 25 de abril de 1961 Autoriza a União a constituir a empresa Centrais Elétricas Brasileiras S. A. - ELETROBRÁS, e dá outras providências. Diário Oficial da União, Rio de Janeiro, 3 out. 1953. Disponível em: < http://www .planalto.gov.br/ccivil_03/leis/12004.htm> Acesso em: 3 mai. 2018.

BRASIL. Lei Federal n. 4.320, de 17 de março de 1964. Estatui Normas Gerais de Direito Financeiro para elaboração e contrôle dos orçamentos e balanços da União, dos Estados, dos Municípios e do Distrito Federal. Diário Oficial da União, Brasília, 23 mar. 1964.

Disponível em: < http://www.planalto.gov.br/Ccivil_03/leis/L4320.htm> Acesso em: 30 abr. 2018 .

BRASIL. Lei Federal n. 6.189, de 16 de dezembro de 1974. Altera a Lei no 4.118, de 27 de agosto de 1962, e a Lei $\mathrm{n}^{0} 5.740$, de 1 de dezembro de 1971, que criaram, respectivamente, a Comissão Nacional de Energia Nuclear - CNEN e a Companhia Brasileira de Tecnologia Nuclear - CBTN [...]. Diário Oficial da União, Brasília, 17 dez. 1974. Disponível em: $<$ http://www.planalto.gov.br/ccivil_03/leis/16189.htm>. Acesso em 3.5.2018.

BRASIL. Lei Federal n. 6.404, de 15 de setembro de 1976. Dispõe sobre as Sociedades por Ações. Diário Oficial da União, Brasília, 17 dez. 1976. Disponível em: <http://www. planalto.gov.br/ccivil_03/leis/L6404consol.htm> Acesso em: 30 abr. 2018.

BRASIL. Lei Federal n. 8.031, de 12 de abril de 1990. Cria o Programa Nacional de Desestatização, e dá outras providências. Diário Oficial da União, Brasília, 13 abr. 1990. 
Disponível em: <http://www.planalto.gov.br/Ccivil_03/leis/L8031.htm>. Acesso em: 30 abr. 2018.

BRASIL. Lei Federal n. 13.303, de 30 de junho de 2016. Dispõe sobre o estatuto jurídico da empresa pública, da sociedade de economia mista e de suas subsidiárias, no âmbito da União, dos Estados, do Distrito Federal e dos Municípios. Diário Oficial da União, Brasília, 01 jul. 2016. Disponível em: <http://www.planalto.gov.br/ccivil_03/_ato20152018/2016/lei/113303.htm> Acesso em: 30 abr. 2018.

BRASIL. Lei Federal n. 13.587, de 2 de janeiro de 2018. Estima a receita e fixa a despesa da União para o exercício financeiro de 2018. Diário Oficial da União, Brasília, 3 jan. 2018a. Disponível em: <http://www.planalto.gov.br/ccivil_03/_ato2015-2018/2018/lei/L13587.htm> Acesso em: 3 mai. 2018.

BRASIL. Mensagem ao Congresso Nacional. Rio de Janeiro: Biblioteca da Presidência, 1954a. Disponível em: <http://www.biblioteca.presidencia.gov.br/publicacoesoficiais/mensagem-ao-congresso-nacional/mensagem-ao-congresso-nacional-getulio-vargas1954/@@download/file/Mensagem\%20ao\%20Congresso\%20Nacional\%20Get\%C3\%BAlio $\% 20$ Vargas\%20-\%201954.pdf>. Acesso em 7.4.2018.

BRASIL. Ministério da Fazenda. Resultado do Tesouro Nacional. Brasília: Tesouro Nacional, 2018b. Disponível em: <http:/www.tesouro.fazenda.gov.br/web/stn/resultado-dotesouro-nacional>. Acesso em 30 abr. 2018.

BRASIL. Projeto de Lei n. 4.280, de 1954. Câmara dos Deputados, Rio de Janeiro, 1954b. Disponível em:

$<$ http://www.camara.gov.br/proposicoesWeb/fichadetramitacao?idProposicao=220244> Acesso em: 3 maio 2018.

BRASIL. Projeto de Lei n. 9.463, de 2018. Câmara dos Deputados, Brasília, 2018c. Disponível em:

$<$ http://www.camara.gov.br/proposicoesWeb/fichadetramitacao?idProposicao=2167572> Acesso em: 3 maio 2018. 
BRASIL. Supremo Tribunal Federal, 2017. Recurso Extraordinário n. 851.711, Relator para o acórdão: Ministro Marco Aurélio. Diário da Justiça Eletrônico no 200, Brasília, 5 set. 2017b. Disponível em:

$<$ http://redir.stf.jus.br/paginadorpub/paginador.jsp?docTP=TP\&docID=14624254>. Acesso em 18.4.2018.

CÂMARA, Jacintho Arruda. O lucro nas empresas estatais. Revista Brasileira de Direito Público - RBDP, Belo Horizonte, ano 10, n. 37, p. 918, abr./jun. 2012.

DINIZ, Angélica; PIZZARO, Ludmila. Estado desmembra Codemig para acelerar privatização: Divisão da empresa pelo governo, com foco na exploração de nióbio, eleva seu valor para R\$ 8 bilhões. O Tempo, Belo Horizonte, 27 fev. 2018. Disponível em: < https://www.otempo.com.br/capa/pol\%C3\%ADtica/estado-desmembra-codemig-paraacelerar-privatiza\%C3\%A7\%C3\%A3o-1.1578312>. Acesso em: 13 mar. 2018.

EMPRESA BRASILEIRA DE CORREIOS E TELÉGRAFOS. Estatuto social. Brasília: CORREIOS, 2018. [Documento aprovado na 11ª . Assembleia Geral Extraordinária, em 30/01/2018] Disponível em: <https://www.correios.com.br/sobre-os-correios/acesso-ainformacao/institucional/base-juridica/pdf/EstatutoSocialdosCorreios.pdf $>$. Acesso em: 18 abr. 2018.

FUNCIONÁRIOS dos Correios entram em greve; veja como evitar problemas: Pagamentos bancários devem ser feitos mesmo que o boleto não chegue. Folha de S. Paulo, São Paulo, 12 mar. 2007. Disponível em: < https://www1.folha.uol.com.br/mercado/2018/03/funcionariosdos-correios-entram-em-greve-veja-como-nao-ser-afetado.shtml>. Acesso em: 18 abr. 2018. GOVERNO anuncia 57 novas privatizações; veja o que será leiloado: entre os ativos que serão vendidos ou concedidos em outorgas há aeroportos, portos, rodovias e a Casa da Moeda. [S. 1.]: G1, 23 ago. 2017. Disponível em: < https://g1.globo.com/economia/ noticia/governo-anuncia-57-novas-privatizacoes-veja-o-que-sera-leiloado.ghtml > . Acesso em: 9 abr. 2018.

INDICADORES econômicos. IV.29 - Dívida líquida e bruta do Governo Geral. Brasília: BCB, 2018. Disponível em: < https://www.bcb.gov.br/pec/Indeco/Port/IE4-29.xlsx > . Acesso em: 3 maio 2018. 
MELLO, Celso Antônio Bandeira de. Curso de direito administrativo. 32. ed. rev. e atual., São Paulo: Malheiros, 2015.

MINAS GERAIS. Lei Estadual n. 22.828, de 3 de janeiro de 2018. Autoriza a transformação da empresa pública Companhia de Desenvolvimento Econômico de Minas Gerais - Codemig - em sociedade de economia mista. Diário Oficial do Estado, 4 jan. 2018. Disponível em: $<$ https://www.almg.gov.br/consulte/legislacao/completa/completa.html?tipo=LEI\&num=2282 $8 \&$ ano $=2018>$. Acesso em: 3 maio 2018.

OLIVEIRA, Fernão Justen de. Os administradores das empresas estatais. In: JUSTEN FILHO, Marçal (Org.). Estatuto jurídico das empresas estatais. São Paulo: Revista dos Tribunais, 2016. p. 141-167.

OLIVEIRA, Régis Fernandes de. Curso de direito financeiro. 6. ed. rev. atual. e ampl., São Paulo: Revista dos Tribunais, 2014.

PINTO JUNIOR, Mario Engler. Empresa estatal: função econômica e dilemas societários. 2. ed. São Paulo: Atlas, 2013.

PEREIRA, Gabriel Senra da Cunha; FARIA, Edimur Ferreira de. O regime jurídico das empresas estatais sob a ótica da lei n. 13.303/2016: aspectos gerais, específicos e polêmicos, Revista de Direito Administrativo e Gestão Pública, Maranhão, v. 3, n. 2, p. 17-37, jul./dez. 2017. Disponível em:

$<$ http://www.indexlaw.org/index.php/rdagp/article/view/2280/pdf>. Acesso em 18 abr. 2018.

RECLAME AQUI. Correios. [S. 1.]: Do Autor, 2017. Disponível em: < https://www. reclameaqui.com.br/empresa/correios/ >. Acesso em: 18 abr. 2018.

SARMENTO, Daniel. Dignidade da pessoa humana. Belo Horizonte: Fórum, 2016.

TESOURO dos EUA injeta bilhões em nove bancos. Folha de S. Paulo, São Paulo, 29 out. 2008. Disponível em: <http://www1.folha.uol.com.br/folha/dinheiro/ult91u461958.shtml>. Acesso em: 9 abr. 2018. 
TONIN, Mayara Gasparoto. Função social das empresas estatais. In: JUSTEN FILHO, Marçal (Org.). Estatuto jurídico das empresas estatais. São Paulo: Revista dos Tribunais, 2016. p. 265-282.

VANELLI, Victor Hugo Pavoni. Fiscalização das empresas estatais pela sociedade. In: JUSTEN FILHO, Marçal (Org.). Estatuto jurídico das empresas estatais. São Paulo: Revista dos Tribunais, 2016. p. 627-640. 


\title{
O PRINCÍPIO DA EFICIÊNCIA DA EXECUÇÃO FISCAL EM PAÍSES DA AMÉRICA LATINA E NA ESPANHA: UM PARALELO ENTRE MODELOS JUDICIAIS E A COBRANÇA ADMINISTRATIVA DO CRÉDITO TRIBUTÁRIO.
}

\author{
Flávio Couto Bernardes \\ Puc/Minas e UFMG \\ Karol Araújo Durço \\ Puc/Minas e UFJF
}

\begin{abstract}
Resumo
O artigo busca estabelecer um paralelo entre os sistemas de cobrança administrativa e judicial do crédito tributário, analisando sistemas da América Latina e da Espanha, sob a ótica do princípio da eficiência administrativa. Para cumprir essa tarefa, além de expor, brevemente, o funcionamento de cada um dos modelos de cobrança, definiu-se o que se entende por eficiência. Ao final, a conclusão foi que o atendimento ao princípio da eficiência administrativa depende mais da modernização do sistema de arrecadação, melhoria da infra-estrutura e desburocratização jurídica, do que da vinculação da cobrança do crédito tributário a um sistema administrativo ou judicial.
\end{abstract}

Palavras-chave: Execução Fiscal, Cobrança Administrativa, Eficiência.

\begin{abstract}
Resumen/Résumé
El artículo busca establecer un paralelo entre los sistemas de cobro administrativo y judicial del crédito tributario, analizando sistemas de América Latina y España, bajo la óptica del principio de la eficiencia administrativa. Para cumplir esta tarea, además de exponer el funcionamiento de cada uno de los modelos de cobro, se conceptuó eficiencia. Al final, la conclusión fue que la atención al principio de la eficiencia administrativa depende más de la modernización del sistema de recaudación, mejora de la infraestructura y desburocratización jurídica, que de la vinculación del cobro del crédito tributario a un sistema administrativo o judicial.
\end{abstract}

Keywords/Palabras-claves/Mots-clés: Ejecución Fiscal, Cobranza Administrativa, Eficiencia. 


\section{Introdução}

O objetivo deste artigo é realizar um paralelo entre os sistemas de arrecadação tributária na América Latina, em comparação com o sistema espanhol, com ênfase na eficiência administrativa.

Para atingir esse objetivo, parte-se de uma pesquisa em fontes secundárias investigando-se a legislação do Brasil, Argentina, Peru, Uruguai e Espanha, além de posições doutrinárias de autores da América Latina e Europa.

No primeiro capítulo, com base nos estudos desenvolvidos por Katherine Baer, John D. Brondolo e Raul Junquera Varela, investigam-se as principais características e entraves dos sistemas de arrecadação tributária dos países latino-americanos. Em seguida, apresentam-se os três principais sistemas de cobrança do crédito tributário nesses países, exemplificados pelo sistema judicializado brasileiro e uruguaio, sistema administrativo peruano e sistema híbrido argentino.

No segundo capítulo, é a vez de se investigar o sistema de arrecadação espanhol, que também possui contornos voltados para a execução administrativa do crédito tributário.

No terceiro capítulo, inicia-se com um estudo a respeito do princípio da eficiência para, em seguida, promover-se uma análise dos modelos acima referidos a partir da moldura traçada pelo mencionado princípio. Ao final, seguem-se as conclusões.

\section{A cobrança do crédito tributário na América Latina: considerações gerais e os modelos do Brasil, do Uruguai, da Argentina e do Peru}

Katherine Baer, funcionária do Departamento de Finanças Públicas do Fundo Monetário Internacional, em importante investigação desenvolvida sobre as tendências da administração tributária na América Latina, sustentou que "durante las últimas décadas, el Departamento de Finanzas Públicas del Fondo Monetário Internacional ha brindado mucha asistencia técnica en programas de reforma para mejorar la eficácia de la administración tributaria em América Latina”. (2006, p. 131)

Em seu estudo apontou, também, a questão da complexidade dos sistemas tributários como uma das causas de ineficiência, apesar da existência de uma contínua busca pela simplificação não só do sistema tributário, mas da própria gestão e do relacionamento com o cidadão-contribuinte, por parte dos países da América Latina. 
Quanto à eficiência da Administração Fazendária na exigência do crédito tributário inadimplido e no combate à evasão fiscal, em estudo realizado por John D. Brondolo (2001), registrou-se que os países da América Latina lideram a lista dos mais morosos quando se refere ao cumprimento dos deveres oriundos das obrigações tributárias, sendo que o Brasil, dos países pesquisados, perde apenas para a Ucrânia ${ }^{1}$.

O problema dessa ineficiência é que o beneficiado é apenas o contribuinte inadimplente com o Estado, além de servir de estímulo a não observância dos deveres legais do sujeito passivo. Claro que o combate à ineficiência não pode servir de justificativa para se aniquilar direitos e garantias fundamentais do contribuinte, em especial a ampla defesa, através de recursos administrativos e judiciais, por constituir uma das vigas do princípio da segurança jurídica. Logo, a mudança deve se dar na eficiência da administração pública e não na supressão dos direitos outorgados ao contribuinte. Como leciona Raul Junquera Varela:

La Administración Tributaria debe tener una estrategia para cumplir con sus responsabilidades. Hay un cierto consenso en que una Administración Tributaria moderna debe promover el cumplimiento voluntario de las obligaciones tributarias, buscando una relación equilibrada y transparente con el contribuyente, facilitándole ese cumplimeinto y prestándole un servicio con los más altos estándares de calidad. (2001, p. 25).

Para cumpri essa tarefa de busca pela eficiência, Katherine Baer indica os principais desafios da Administração Tributária nos países da América Latina: a) assegurar um sistema tributário estável e previsível, realizando reformas que atendam a este fim; b) evoluir na profissionalização da gestão tributária, garantindo melhor infraestrutura, tanto no aspecto da informatização, como na formação de recursos humanos; c) alteração dos Códigos Tributários de forma a atribuir as competências necessárias à eficiência da gestão tributária, no que se deve acrescentar, com a necessidade de observância dos direitos fundamentais do cidadãocontribuinte; d) propiciar mecanismos que garantam a agilidade no trâmite dos procedimentos e processos administrativos e judiciais; e) transparência nas regras integrantes do sistema

\footnotetext{
${ }^{1}$ No mesmo sentido, Katherine Baer, destaca que: "En la mayoría de los países de la región, la cobranza coactiva de los impuestos es responsabilidad del poder judicial. Las administraciones tributarias disponen de escasas competencias para el cobro de impuestos a los contribuyentes morosos. En muchos códigos tributarios se establece el criterio de suspensión de pago del impuesto una vez que el contribuyente recurre ante la instancia judicial sin requerirle que presente alguna garantía. Esto deja a la administración tributaria desprotegida para recuperar por lo menos parte de la deuda morosa y en muchos países incentiva el uso del mecanismo del recurso judicial para postergar el pago de los impuestos. [...] Al mismo tiempo, en muchos países, la tramitación de los juicios en vía contencioso-administrativa, en vía judicial ou en vía penal es muy lenta, lo que retrasa la sanción de los incumplimientos por parte de los contribuyentes morosos". (2006, p. 135)
} 
tributário, sobretudo na arrecadação e na fiscalização dos tributos²; f) eficácia na aplicação das sanções de origem tributária; g) alterações que permitam a integração da Administração Tributária, combatendo a evasão fiscal; h) evitar a concessão de isenções, anistias e parcelamentos especiais, impedindo o estímulo à inadimplência.

Fixadas essas premissas, resta indicar a forma como tem ocorrido a efetivação dos créditos tributários na América do Sul, o que será apresentado a partir dos modelos do Brasil, do Uruguai, da Argentina e do Peru.

\subsection{O modelo judicial de execução fiscal}

\subsubsection{O modelo brasileiro}

Tradicionalmente, no Brasil, percorrem-se as necessárias etapas de um procedimento administrativo de constituição do crédito tributário, ao final do qual resta materializada a Certidão da Dívida Ativa. Tal certidão é título executivo apto a permitir o exercício do direito de ajuizamento da ação de execução fiscal perante o Poder Judiciário. Portanto, sempre foi por meio de ação judicial de execução fiscal que ocorreu a persecução do recebimento do crédito tributário inadimplido, valendo-se do mecanismo de expropriação de bens do devedor, tudo regulado pela Lei no. 6.830/80, conhecida como "Lei de Execução Fiscal".

Conforme ensina José da Silva Pacheco (2002, p. 10),

[...] a execução judicial, a que se alude o art. $1^{\circ}$, e que vai denominada de execução fiscal nos arts. $4^{\circ}, 12,25$ e 26 da lei que comentamos, é a execução singular por quantia certa, com base em título executivo extrajudicial, constituído pela certidão de dívida ativa regularmente inscrita, de caráter expropriatório, que se realiza no interesse da Fazenda Pública, como tal compreendida a União, os Estados, o Distrito Federal, os Municípios e respectivas autarquias.

Nesse sentido, após citação do executado, o mesmo terá o prazo de cinco dias para pagar ou garantir a execução, nos termos do art. $8^{\circ}$ da Lei, ressaltando que poderá garantir a execução por depósito, fiança, seguro garantia, indicação à penhora de bens próprios ou de

\footnotetext{
${ }^{2}$ Raul Junquera Varela, em seu estudo, afirma que: "en general hay una importante utilización de Internet como mecanismo de atención al contribuyente, así como un medio de facilitación de la entrada de información a efectos de su utilización en los procesos de gestión tributaria." (2001, p. 27) Como destaques na informatização, podem ser apontados, na América Latina, Brasil, Chile e México, sobretudo pelo exemplo da entrega de declarações eletrônicas de rendimentos.
} 
terceiros, tudo conforme o art. $9^{\circ}$, do mesmo diploma legal. Caso não o faça, nos termos do art. 10, a penhora poderá recair em qualquer bem do executado, exceto os que a lei declare absolutamente impenhoráveis. Nessa esfera, para se defender, o executado pode se valer de Embargos à Execução, os quais só serão admitidos depois de garantida a execução, conforme dispõe o art. 16 da Lei de Execução Fiscal.

Logo, no Brasil, até janeiro de 2018, a ação de execução fiscal era o único instrumento processual tributário para a busca de satisfação do crédito tributário.

Não obstante, em 9 de janeiro de 2018, foi publicada a Lei no 13.606, que institui "o Programa de Regularização Tributária Rural (PRR)" tendo sido utilizado seu art. 25 para acrescentar os arts. 20-B, 20-C, 20-D e 20-E à Lei $n^{\circ}$. 10.522, de 19 de julho de 2002, que "Dispõe sobre o Cadastro Informativo dos créditos não quitados de órgãos e entidades federais e dá outras providências".

Tais dispositivos normativos permitem seja o devedor, administrativamente, notificado para, em até cinco dias, efetuar o pagamento do valor inscrito em dívida ativa da União. Chama atenção, contudo, o $\S 3^{\circ}$, do art. 20-B, que estabeleceu a regra segundo a qual, não pago o débito no prazo de cinco dias, a Fazenda Pública poderá comunicar a inscrição em dívida ativa aos órgãos que operam bancos de dados e cadastros relativos a consumidores e aos serviços de proteção ao crédito e congêneres; e averbar, inclusive por meio eletrônico, a certidão de dívida ativa nos órgãos de registro de bens e direitos sujeitos a arresto ou penhora, tornandoos indisponíveis. $\mathrm{O}$ art. 20-D garantiu, ainda, amplos poderes investigatórios a administração fazendária permitindo notificar pessoas para prestar depoimentos; requisitar informações, exames periciais e documentos de quaisquer órgãos ou autoridades, sejam federais, estaduais ou municipais; e instaurar procedimento administrativo para apuração de responsabilidade por débito inscrito em dívida ativa da União.

Esse último dispositivo legal, embora tenha sido vetado sob o fundamento de que não deixa claro o seu escopo, nem os limites das requisições, tampouco os órgãos afetados, causando "insegurança jurídica", teve o veto derrubado em abril de 2018, motivo pelo qual está em vigor, assim como os demais.

Não obstante, tais dispositivos legais são, potencialmente, violadores de inúmeras disposições constitucionais, das quais se destacam o contraditório e a ampla defesa (artigo $5^{\circ}$, LV, da Constituição Federal de 1988); o devido processo legal substantivo e a inafastabilidade da jurisdição (artigo 5 , LIV e XXXV); e a necessidade de Lei complementar para o estabelecimento de normas gerais sobre crédito tributário (artigo 146, III, “b”). 
Em relação ao contraditório, ampla defesa e ao devido processo legal, se observa que as providências administrativas que agora poderão ser adotadas unilateralmente pela União, na busca de satisfação do crédito tributário, são passíveis de causar graves danos aos negócios dos contribuintes, que poderão ter uma série de bens imprescindíveis ao desenvolvimento de suas atividades bloqueados (por exemplo, capital de giro, veículos, maquinários, imóveis, ações, investimentos etc.), sem a intervenção e respaldo por decisão de um terceiro imparcial. Ocorre que eventual atribuição da existência de má-fé por parte do contribuinte e a constituição unilateral de indisponibilidade de bens pelo próprio ente interessado na execução da dívida e sem que haja uma decisão imparcial e prévia, representa, na verdade, imposição coercitiva disfarçada para se afastar da discussão de direito que se daria em sede judicial, muitas vezes envolvendo a própria existência da dívida.

Quanto à reserva de Lei complementar, tais dispositivos normativos, editados por Lei ordinária, indiscutivelmente ampliaram as garantias do crédito tributário federal, para além daquelas previstas nos artigos 185 e 185-A do Código Tributário Nacional (CTN), o que não se pode admitir como correto.

Ademais, antes da edição desses dispositivos normativos, a Fazenda Pública já possuía instrumentos legais que permitiam a imposição de restrições e o bloqueio de bens, como é o caso do procedimento cautelar fiscal, previsto pela Lei $\mathrm{n}^{\mathrm{o}}$. 8.937/92 que, contudo, é condicionado a decisão judicial e exige a prova da suspeita de fraude à dívida ativa, ou mesmo o bloqueio preventivo de bens (artigo 185-A do CTN) e o arrolamento de bens e direitos (Instrução Normativa RFB 1.565/2015).

O novo sistema, porém, permite o bloqueio administrativo de bens sem a definição de qualquer requisito, com exceção de se tratar de crédito inscrito em dívida ativa.

Ora, entende-se que permitir o bloqueio unilateral de bens pelo próprio ente credor e executor da dívida é permitir espécie de sanção política camuflada, as quais vêm sendo afastadas pela jurisprudência do Supremo Tribunal Federal, em especial por representarem restrição desproporcional ao desenvolvimento de atividade econômica ou de profissão lícita para garantir ou induzir ao pagamento de tributo, como resta claro pelo teor das súmulas 70 , 323 e $547^{3}$.

\footnotetext{
3 Súmula 70: É inadmissível a interdição de estabelecimento como meio coercitivo para cobrança de tributo; Súmula 323: É inadmissível a apreensão de mercadorias como meio coercitivo para pagamento de tributos; Súmula 547: Não é lícito à autoridade proibir que o contribuinte em débito adquira estampilhas, despache mercadorias nas alfândegas e exerça suas atividades profissionais.
} 
Além disso, tradicionalmente, no Brasil, o poder de tomar medidas acauteladoras envolvendo a constrição de bens é prerrogativa exclusiva do Poder Judiciário. Admitir a ação unilateral da Fazenda Pública viola o princípio da reserva de jurisdição, previsto no art. $5^{\circ}$, inciso XXXV, da Constituição Federal de 1988, segundo o qual “a lei não excluirá da apreciação do Poder Judiciário lesão ou ameaça a direito”. No mesmo sentido, é interessante recordar que na sistemática constitucional de separação dos Poderes, cabe ao Judiciário evitar medidas arbitrárias tomadas pelo Executivo na cobrança de seus créditos.

É relevante anotar, também, que a inconstitucionalidade de medidas que configurem a chamada execução administrativa já foi reconhecida pela jurisprudência do Supremo Tribunal Federal, como é exemplo o julgamento do Recurso Extraordinário 591.033/SP.

Por fim, vale mencionar que a constitucionalidade de tais dispositivos já está sendo objeto de questionamento junto ao Supremo Tribunal Federal pela via da Ação Direta de Inconstitucionalidade, como é o caso da ADI 5881, proposta pelo Partido Socialista Brasileiro - PSB, que, por ora, teve a liminar indeferida pelo Ministro Relator, Marco Aurélio Mello.

De todo modo, após eventual bloqueio de bens, o caminho da execução continua sendo judicial e como as alterações são muito recentes e passíveis de afastamento judicial, continuase entendendo que o modelo executivo brasileiro é judicial.

\subsubsection{O modelo uruguaio}

Assim como no Brasil, no Uruguai, se faz necessário recorrer ao Poder Judiciário para promover a persecução do crédito tributário. Isso é o que define o próprio Código Tributário uruguaio, que em seu art. 91 prescreve: “La Administración tendrá acción ejecutiva para el cobro de los créditos fiscales que resulten a su favor según sus resoluciones firmes" [...].

Porém, o sistema uruguaio, embora também judicial, possui algumas distinções do sistema brasileiro. Em primeiro lugar, no Uruguai, não existe uma Lei específica para Execução Fiscal, como ocorre no Brasil. Conforme o art. 362 do Código Geral de Processo uruguaio "El proceso ejecutivo para el cobro de créditos fiscales se tramitará según lo dispuesto en los artículos precedentes, sin perjuicio de la aplicación de las leyes especiales en la materia”. Por sua vez, os artigos precedentes (arts. 354-361), referidos pelo dispositivo legal, regulam o processo monitório que é a regra de cobrança dos tributos no Uruguai.

Portanto, no sistema judicial uruguaio, o mesmo procedimento para cobrar créditos amparados por prova documental é utilizado para cobrança dos créditos tributários, tudo previsto pelo Código Geral de Processo. Cumpre advertir, de todo modo, que o processo 
monitório no Uruguai não possui os mesmos moldes do brasileiro, não obstante pressupor, também, prova documental escrita da dívida ${ }^{4}$ e, ademais, segundo Francisco Cobas e Hugo Lens (2015, p 55-56), existem diferenças entre o processo monitório comum e o tributário. Tais autores enumeram, ao menos, nove diferenças, quais sejam:

a) no se requiere la intimación de pago previa, regulada en el inciso $6^{\circ}$ del artículo 53 de la ley 13.355/93, lo cual está en consonancia con la redacción del artículo 354.5 del Código General del Proceso que prevé la exención de exigir la intimación cuando las leyes especiales así lo dispongan; b) no se requiere la conciliación previa; c) las únicas notificaciones personales son las que corresponden al decreto que cita de excepciones, la que convoca audiencia preliminar y la sentencia de remate; d) las excepciones que puede oponer el deudor son limitadas, y están establecidas a texto expresso; e) se prevé la suspensión del proceso en ciertos casos concretos; f) posibilidad de promover el juicio ordinario posterior; g) posibilidad de embargar cuentas bancarias solo con brindar los datos identificatorios del deudor, tal como el RUT o la cédula de identidade; h) se tiende a la rápida formación de un título de ejecución; i) hay condenas preceptivas para el demandado

De todo modo, independente de tais diferenças entre o procedimento monitório tributário e o comum, chama atenção o fato de que, no Uruguai, o crédito tributário, em regra, não vem consubstanciado em título executivo, tendo em vista que o processo monitório é entendido pelos próprios doutrinadores uruguaios como processo de conhecimento (SANTI: 2013) (GOMES: 2015).

\subsection{O modelo administrativo de cobrança do Peru}

O denominado procedimento de execução coativa das obrigações de natureza tributária e não tributária, no Peru, foi regulamentado pela Lei $\mathrm{n}^{\circ}$. 26.979 , posteriormente alterada pelas Leis $\mathrm{n}^{\circ} .28 .165$ e $\mathrm{n}^{\circ} .28 .892$. Trata-se de processo administrativo que somente

\footnotetext{
${ }^{4}$ Logo após o ingresso do processo monitório, o Poder Judiciário decide, sem oitiva da parte requerida, sobre sua admissibilidade e fundabilidade. A admissibilidade refere-se aos requisitos processuais, podendo, inclusive, determinar emenda à petição inicial, conforme art. 119.1 do Código Geral de Processo. A fundabilidade diz respeito ao controle do documento apresentado para embasar a ação. Se o mesmo não for considerado suficiente, o Poder Judiciário extinguirá a ação, sem julgamento de mérito. Por outro lado, se a demanda passar pelo controle liminar de admissibilidade e fundabilidade, a sentença inicial julgará existente o crédito (sem oitiva do demandado), podendo, ainda, adotar providências de natureza cautelar tendentes a assegurar o direito do autor. Desta sentença, o demando é citado para opor exceções (defesa), quando será inaugurada verdadeira fase de conhecimento. Caso não sejam apresentadas exceções, e uma vez expirado o prazo para essa finalidade, seguem os procedimentos expropriatórios inaugurando-se a fase de execução. (CAMPOS: s.d.) (FERNÁNDEZ; CAL: 2014, p. 134).
} 
pode ser revisto pelo Poder Judiciário na hipótese de erro na aplicação dos aspectos formais da exigência tributária, vedado entrar no mérito da cobrança tributária ${ }^{5}$.

A relação jurídica processual se instaura entre o Ejecutor Coactivo, titular do procedimento, que age em nome da entidade (Administração Pública Nacional dotada do poder de exigência do dever tributário), promovendo as ações coercitivas para o cumprimento da obrigação, e o Obligado, denominado em outras legislações de sujeito passivo desta relação (contribuinte e responsável tributário).

O procedimento administrativo de cobrança tributária depende da formação válida do respectivo título executivo extrajudicial, mediante a imprescindível e prévia notificação da Entidade ao Contribuinte, que poderá interpor recurso administrativo, discutindo a exigência tributária antes deste procedimento coativo. Presente este título, o Executor notificará o Obrigado sobre a Resolución de Ejecución Coactiva, determinando o cumprimento de seu dever jurídico no prazo de 7 (sete) dias.

Os arts. 13 e 28, do mencionado diploma legal, autorizam a adoção das intituladas Medidas Cautelares Previas. Buscam, portanto, assegurar o recebimento do crédito tributário pela Administração Tributária, antes de iniciado o procedimento de execução. Terão o prazo de validade de 30 (trinta) dias, prorrogável por igual período, podendo ser adotadas mesmo que pendente o julgamento de recurso administrativo interposto pelo sujeito passivo. Não poderão, contudo, atingir veículos automotores e serão suspensas na hipótese de oferecimento de fiança bancária pelo Obrigado.

A Resolución de Ejecución Coactiva equivale ao título executivo extrajudicial (Certidão da Dívida Ativa brasileira), que consubstancia a existência do crédito tributário, pressupondo a regularidade na sua formação. Deve possuir os requisitos previstos no art. 15 da Lei, sob pena de nulidade. Nota-se que os requisitos em questão são bastante similares ao da legislação brasileira, inclusive no tocante ao reconhecimento da nulidade na hipótese da sua não observância.

Ademais, apenas o Executor, de acordo com o art. 16, pode determinar a suspensão do procedimento de cobrança coativa, vedada a interferência de outros órgãos da Administração, inclusive de natureza política. O Poder Judiciário poderá determinar a suspensão apenas nas hipóteses em que numa acción de amparo exista medida cautelar efetiva.

\footnotetext{
5 “Art. 23 - Revisión judicial del Procedimiento. 23.1 - Sólo después de concluido el Procedimiento, el Obligado podrá interponer demanda ante la Corte Superior dentro de un plazo de quince (15) días hábiles de notificada la resolución que pone fin al Procedimiento. 23.2 - Al resolver, la Corte Superior examinará únicamente si se há tramitado el Procedimiento conforme a ley, sin que pueda entrar al análisis del fondo del asunto o de la procedência de la cobranza o, em sua caso, de la procedência de la obligación de hacer o no hacer".
} 
A penhora poderá ser realizada na forma de intervenção no faturamento das empresas, assim como na administração de seus bens, desde que não afete o processo de produção da empresa. Nos casos de recair sobre bens imóveis, o sujeito passivo deverá ser nomeado depositário.

O Executor poderá realizar a arrematação do bem penhorado, separando o valor correspondente ao crédito tributário devido e entregando o saldo remanescente, porventura existente, ao próprio sujeito passivo ou ao terceiro, na hipótese da penhora ter se efetivado em valores disponíveis com os mesmos.

Apesar da manifestação de Willy Pedreschi Garcés, no sentido de que "las modificaciones introducidas recientemente en la legislación del procedimento de ejecución coactiva tienen por objeto exclusivo la restricción del ejercicio abusivo e ilegal de la potestad de autotutela por parte da la Administración Pública”, constata-se uma ausência significativa de normas ressalvando as garantias fundamentais do cidadão, sobretudo no tocante ao princípio da ampla defesa.

\subsection{O modelo híbrido de cobrança da Argentina}

O procedimento fiscal de execução na Argentina foi regulamentado pela Lei n. 11.683/98, posteriormente alterada, no ano de 2000, pela Lei n. $25.239^{6}$. O objetivo primordial da modificação foi o de otimizar os procedimentos de cobrança dos créditos tributários, assegurando uma maior eficiência à Administração Pública. Para tanto, foi atribuído aos órgãos fazendários uma maior autonomia de atuação, não dependendo de ingressar com a ação perante o Poder Judiciário para a adoção, por exemplo, das medidas de natureza cautelar, permitindo a prática de atos administrativos auto-executivos ${ }^{7}$.

O procedimento administrativo, antes da alteração legislativa mencionada, iniciava-se com as determinações judiciais, a partir da solicitação da Administração. Agora, o primeiro ato é praticado pelo Agente Fiscal competente, que se limita a informar ao juízo a existência da

\footnotetext{
${ }^{6}$ Segundo Catalina García Vizcaíno, a execução fiscal: "constituye un proceso judicial singular de ejecución, se cognición restringida, a fin de asegurar el cumplimiento de una obligación documentada en títulos a los cuales se les atribuye fehaciencia, para que el fisco realice su derecho creditorio en forma expeditiva, sin perjuicio del adecuado resguardo del derecho de defensa. Se fundamenta en el principio de legitimidad de los actos administrativos". (1997, p. 226).

7 A validade desta alteração legislativa, conferindo ao agente fiscal administrativo funções tipicamente jurisdicionais, tem sido discutida no Poder Judiciário argentino, tendo em vista que o texto constitucional faz previsão da respectiva competência deste poder para a solução dos conflitos. Remete-se o leitor à enumeração jurisprudencial apresentada por Elizabeth A. Conti, na página 33 e seguintes de seu artigo. (El Nuevo Procedimiento de Ejecución Fiscal en la República Argentina).
} 
dívida tributária e demais informações relativas ao contribuinte, expedindo o respectivo ato de intimação. O servidor público poderá, inclusive, adotar medidas cautelares prévias ou posteriores, no intuito de preservar a eficácia do procedimento com relação ao recebimento do crédito tributário, além de realizar a penhora de bens móveis e imóveis ou bloqueio de contas bancárias ${ }^{8}$.

Este caráter híbrido da execução fiscal na Argentina foi assim definido por Carlos Mario Borgonovo (p. 05), que o considera válido perante o ordenamento jurídico do país:

\begin{abstract}
El nuevo Art. 92 modificado por la ley 25239 (t.o. ley 11.683) encierra dos tipos de ejecuciones fiscales según el contribuyente oponga o no excepciones; en el pimer caso la excepción y defensa es tratada y decidida por el juez competente que dicta la setencia respectiva; en el segundo caso, no existe intervención material de la justicia, sino que bajo, la apariencia de un proceso de ejecución administrativa, en la que no existe intervención judicial ni para disponer y trabar medidas cautelares ni para dictar sentencia de trance y remate. La intervención del juezen este caso se limita a ordenar el secuestro de los bienes o la transferencia de los fondos embargados.

[...]

Si bien el proceso dispone de algunas ventajas propias que persiguen comprimir el conocimiento mediante la reducción del número de defensas. Acotamiento de recursos, etc., se ha considerado que ello, en principio, no vulnera las garantías constitucionales del debido proceso legal, la igualdade de las partes, el ejercicio de defensa.

Se há procurado así conjugar equilibradamente la protección de los derechos e intereses de las partes y poner en manos del Estado un procedimiento ágil, que permita perseguir el cobro de las obligaciones fiscales adeudadas, en forma rápida y efectiva.
\end{abstract}

Confirma-se, assim, que o processo de execução fiscal foi, em grande parte, substituído por um procedimento da Administração Tributária, em que os atos administrativos foram dotados de definitividade e auto-executoriedade. Neste passo, foi revertida a possibilidade de revisão judicial do fundamento do crédito tributário, da motivação do ato de lançamento, restando ao sujeito passivo a discussão administrativa do título executivo (Boleta de deuda) ${ }^{9}$.

Na Argentina, a execução fiscal permanece como ação judicial, prevista no Código de Processo Civil e Comercial Nacional. No entanto, foi conferida à Administração Fazendária uma gama de atribuições que lhe permitem a realização da penhora e uma série de atos

\footnotetext{
8 “Articulo 111 - En cualquier momento la ADMINISTRACION FEDERAL DE INGRESOS PUBLICOS podrá solicitar embargo preventivo, o en su defecto, inhibición general de bienes por la cantidad que presumiblemente adeuden los contribuyentes o responsables o quienes puedan resultar deudores solidarios y los jueces deberán decretarlo en el término de veinticuatro (24) horas, ante el solo pedido del fisco y bajo la responsabilidad de éste".

${ }^{9}$ A jurisprudência argentina faz menção similar à abordagem apresentada neste trabalho, ao decider: "el título ejecutivo del Fisco tiene la característica de su origen unilateral, surge de la ley y se documenta por los funcionarios, com las formalidades que la propria ley señala, destacándose su autonomia y completividad al punto de no necesitar de ningún outro documento." (BORGONOVO, p. 11).
} 
administrativos auto-executáveis, no âmbito do "processo judicial". Nos dizeres de Héctor B. Villegas, "en el régimen nacional y en el de la generalidad de las provincias, basta la boleta de deuda expedida por la autoridad fiscal para abrir el procedimiento. El juez se limita a apreciar si esa boleta de deuda reúne las formas extrínsecas habilitantes”. (VILLEGAS: 1995, p. 455)

O juiz competente para proceder à tramitação da ação de execução fiscal deverá examinar o preenchimento destes requisitos, além da regularidade do procedimento, nos termos do art. 531 do Estatuto Processual. O impulso processual, contudo, será realizado pelo agente fiscal, integrante da Administração Pública, ficando o juiz restrito ao exame das exceções ligadas à regularidade e liquidez do título executivo, cujas causas encontram-se previstas no art. 92 da Lei $\mathrm{n}^{\circ} .11 .683$ (VILLEGAS: 1995, pp. 456 e ss): a) pagamento total da dívida tributária, sendo que o parcial realizado após a ação de execução não lhe retira a liquidez; b) parcelamentos; c) prescrição; d) nulidade do título, incluindo a existência da coisa julgada, litispendência, incapacidade civil com ausência de representação e incompetência do juízo (FONROUGE: 1993, pp. 822 e ss). Elizabeth A. Conti aponta que além destas previsões normativas, a doutrina e a jurisprudência vacilam quanto à admissão da inconstitucionalidade como motivo da exceção. Afirma que "doctrinariamente, autores de prestigio consideran procedente ésta excepción en la ejecución fiscal, por tratarse de una defensa autónoma, que no puede confundirse con la inhabilidad de título. La jurisprudencia se encuentra divida, pero la mayoría de las decisiones son adversas a la admisibilidad de ésta defensa”. (p. 19)

No mesmo sentido Catalina García Vizcaíno:

Pese al carácter taxativo que surge, a simple vista, de la norma en cuanto a las excepciones que pueden ser opuestas, no parece dudoso que puedan ser articuladas también las siguientes: incompetencia, litispendencia, falta de legitimación pasiva, cosa juzgada, falta de personería, condonación de la multa que se intenta ejecutar, excepcionalmente la defensa de inconstitucionalidad, etc., en cuanto sean de manifiesta procedencia.(1997, p. 228)

Na hipótese da não interposição da medida judicial de exceção à execução, por parte do sujeito passivo, o agente fiscal iniciará a liquidação, mediante notificação do devedor e o respectivo informe ao juiz, podendo existir impugnação nesta fase, de acordo com o Código de Processo Civil. Em síntese, não há previsão de decisão judicial para arrematação do bem, que, em tese, pode ser realizada pelo agente fiscal ${ }^{10}$.

\footnotetext{
10 "Es decir que tenemos actualmente en el orden nacional dos procedimientos de ejecución fiscal: el del Código
} Procesal (arts. 604 y 605) y el de la ley 11.683 (arts. 92 a 95 del t.o.1978). Las diferencias entre ellos son 


\section{A Cobrança do crédito tributário na Espanha}

O modelo de cobrança do crédito tributário na Espanha também é baseado em um formato administrativo. Na realidade, naquele país, a cobrança de tributos ou a recaudación tributaria ocorre, em regra, pela declaração e recolhimento voluntário dos tributos pelos contribuintes, já a cobrança coativa ocorre por meio do denominado procedimiento de apremio.

Nesse sentido, são as disposições do art. 160, da Ley General Tributária espanhola:

Artículo 160. La recaudación tributaria.

1. La recaudación tributaria consiste en el ejercicio de las funciones administrativas conducentes al cobro de las deudas tributarias.

2. La recaudación de las deudas tributarias podrá realizarse:

a) En período voluntario, mediante el pago o cumplimiento del obligado tributario en lós plazos previstos en el artículo 62 de esta ley.

b) En período ejecutivo, mediante el pago o cumplimiento espontáneo del obligado tributario o, en su defecto, a través del procedimiento administrativo de apremio.

Portanto, o pagamento voluntário ocorre na forma e nos prazos previstos no art. 62 da Lei, já a execução fiscal, ocorre por meio do procedimiento administrativo de apremio.

Tal instrumento de cobrança coativa é regulado pela Lei Geral Tributária ou, sem tradução, Ley General Tributária, em seus artigos 163 a 173, na qual é previsto o procedimento de apremio, que é, na realidade, a execução fisscal administrativa espanhola.

É importante observar, desse modo, que a cobrança de dívidas tributárias na Espanha é estruturada em dois períodos ou fases distintas e sucessivas. Na primeira fase, que pode ser descrita como fase voluntária, o contribuinte declara e recolhe espontaneamente o tributo apurado segundo a legislação tributária aplicável. Na segunda fase, de caráter executivo administrativo, caso não ocorra o pagamento voluntário ou se o pagamento realizado não estiver correto, o contribuinte submete-se ao procedimento administrativo de execução.

O art. 163, da Lei Geral Tributária, traz as características desse procedimento:

Artículo 163. Carácter del procedimiento de apremio.

1. El procedimiento de apremio es exclusivamente administrativo. La competencia para entender del mismo y resolver todas sus incidencias corresponde únicamente a la Administración tributaria.

2. El procedimiento administrativo de apremio no será acumulable a los judiciales ni a otros procedimientos de ejecución. Su iniciación o tramitación no se suspenderá por la iniciación de aquéllos, salvo cuando proceda de acuerdo con lo establecido en

apreciables y han originado dudas no siempre resueltas en forma coincidente; de aqui la perplejidad del intérprete ante ciertas disposiciones." (FONROUGE: 1993, p. 819). 
la Ley Orgánica 2/1987, de 18 de mayo, de Conflictos Jurisdiccionales, o con las normas del artículo siguiente.

La Administración tributaria velará por el ámbito de potestades que en esta materia Le atribuye la Ley de conformidad con lo previsto en la legislación de conflictos jurisdiccionales.

3. El procedimiento de apremio se iniciará e impulsará de oficio en todos sus trámites $y$, una vez iniciado, sólo se suspenderá en los casos y en la forma prevista en la normativa tributaria.

Logo, iniciado o período executivo, a administração tributária espanhola pode cobrar coercitivamente seu crédito, por meio de processo de execução administrativo, conduzido por ela própria, com a possibilidade de utilização das várias prerrogativas que a legislação espanhola the atribui para a cobrança do crédito tributário. Na verdade, o processamento judicial da execução fiscal é vedado no ordenamento espanhol, como lembra Arnaldo Sampaio de Moraes Godoy (2017).

Essa execução fiscal administrativa inicia-se e se desenvolve por impulso oficial da própria administração, suspendendo-se, excepcionalmente, apenas nos casos de suspensão da exigibilidade do crédito exequendo ou quando demonstrada, de plano, a insubsistência do crédito tributário. A execução fiscal administrativa é instruída por título executivo, denominado de providencia de apremio, e dotado de presunção de exigibilidade, liquidez e certeza, consistindo em documento apto a ensejar a penhora administrativa, ao qual é atribuída, pelo art. 167, a mesma força executiva de uma sentença judicial, sujeitando-se, ainda, a um rol limitado de defesas ${ }^{11}$.

Em relação ao procedimento em si, a execução fiscal administrativa espanhola se inicia com a notificação do devedor, na qual deve constar a identificação da dívida e a discriminação dos valores do principal e acessórios cobrados (recargos del período ejecutivo). Decorrido o prazo de pagamento, a Administração tributária espanhola pode efetuar, imediatamente, penhora administrativa de bens do devedor, expedindo-se nova notificação, garantindo-lhe o direito de contestação da cobrança. Caso rejeitada a defesa, passa-se à fase da tomada definitiva

\footnotetext{
${ }^{11}$ Artículo 167. Iniciación del procedimiento de apremio. 1. El procedimiento de apremio se iniciará mediante providencia notificada al obligado tributario en la que se identificará la deuda pendiente, se liquidarán los recargos a los que se refiere el artículo 28 de esta ley y se le requerirá para que efectúe el pago. 2. La providencia de apremio será título suficiente para iniciar el procedimiento de apremio y tendrá la misma fuerza ejecutiva que la sentencia judicial para proceder contra los bienes y derechos de los obligados tributarios. 3. Contra la providencia de apremio sólo serán admisibles los siguientes motivos de oposición: a) Extinción total de la deuda o prescripción del derecho a exigir el pago. b) Solicitud de aplazamiento, fraccionamiento o compensación en período voluntario y otras causas de suspensión del procedimiento de recaudación. c) Falta de notificación de la liquidación. d) Anulación de la liquidación. e) Error u omisión en el contenido de la providencia de apremio que impida la identificación del deudor o de la deuda apremiada. 4. Si el obligado tributario no efectuara el pago dentro del plazo al que se refiere el apartado 5 del artículo 62 de esta ley, se procederá al embargo de sus bienes, advirtiéndose así en la providencia de apremio.
} 
dos bens do executado, com o leilão ou adjudicação dos bens penhorados. Da mesma forma como no Brasil, a penhora deverá incidir, preferencialmente, sobre dinheiro, bens móveis e imóveis, sendo possível, também, ao contrário do Brasil, recair sobre soldos, salários e aposentadorias. De todo modo, a alienação do bem penhorado depende do esgotamento da via recursal em face da decisão administrativa relativa à respectiva execução fiscal. Por fim, nos termos do art. 173, extingue-se o procedimento com o recolhimento do crédito, com a extinção do mesmo por qualquer outra causa ou com a constatação de que o débito fiscal não seja mais passível de cobrança em razão da declaração de falência ou insolvência dos obrigados ao pagamento.

\section{A eficiência administrativa}

\subsection{O princípio da eficiência administrativa na ordem tributária}

Apesar da administração Pública, em regra, não atuar na atividade econômica, deve realizar suas atividades próprias com eficiência, devendo produzir resultados de modo a atender, o mais breve possível, as necessidades dos cidadãos (FARIA: 2015, p. 67).

A eficiência, portanto,

[...] impõe a todo agente público realizar suas atribuições com presteza, perfeição e rendimento funcional. É o mais moderno princípio da função administrativa, que já não se contenta em ser desempenhada apenas com legalidade, exigindo resultados positivos, para o serviço público e satisfatório atendimento das necessidades da comunidade e de seus membros. (MEIRELLES: 1996, p. 90-91)

No mesmo sentido, Maria Sylvia Zanella Di Pietro (2002, p. 83) afirma que uma administração eficiente pressupõe qualidade, presteza e resultados positivos, constituindo, em termos de administração pública, um dever de mostrar rendimento funcional, perfeição e rapidez dos interesses coletivos.

Não foi por outro motivo que, no Brasil, apesar de não estar no texto original da vigente Constituição Federal de 1988, restou positivado pela Emenda Constitucional n 19/98, que, dentre outras mudanças, acrescentou o princípio da eficiência ao caput do art. 37.

No âmbito tributário, a profissionalização da gestão tributária, afastando a estrutura do sistema tributário de influências políticas negativas, tem sido registrada como tendência para assegurar a eficácia da administração pública. Este aprimoramento decorre da estruturação interna das Administrações Tributárias, com a integração dos diversos setores da tributação, 
como se observa em diversas tentativas que vem sendo realizadas na Argentina, no Brasil, na Colômbia, no México e no Peru. (BAER: 2006, p. 131)

No mesmo sentido, na América Latina, muitos países têm obtido significativo êxito na criação de órgãos especializados na fiscalização e cobrança dos denominados "Grandes Contribuintes", além de unidades especializadas para o monitoramento dos negócios jurídicos firmados e do combate à evasão fiscal (Inteligência Tributária), como ocorre no Brasil. (BAER: 2006)

Do mesmo modo, também merece referência a inserção na legislação tributária de mecanismos de responsabilidade por substituição tributária, sobretudo por meio da realização de retenções pelas fontes pagadoras. Este instituto jurídico está previsto, principalmente, nos impostos indiretos, como o IVA e o ICMS (Brasil), além do imposto de renda.

A eficiência, porém, deve ser compatibilizada com outros princípios da ordem tributária. Pois bem, passa-se a análise dos modelos de cobrança do crédito tributário antes enunciados em face da eficiência administrativa.

4.2. Uma análise dos modelos de cobrança do crédito tributário à luz da eficiência administrativa

A busca por eficiência dos mecanismos de execução fiscal mostra-se fundamental para o adequado funcionamento de todo sistema tributário. Além de prestigiar o contribuinte adimplente, por diferenciá-lo do inadimplente e evitar aumento da carga tributária, traz vantagens também para a administração pública e para o interesse público, vez que as receitas necessárias aos gastos públicos estarão disponíveis para fazerem frente aos compromissos estatais, além de não haver dúvidas de que é mecanismo de combate à sonegação por desestimular a inadimplência tributária por parte dos contribuintes.

Como destacam os argentinos Jorge Vignale e Jorge Benzrihe "Una eficiente Administración Tributaria permitirá reducir la presión impositiva sobre los contribuyentes cumplidores, favoreciendo así el incremento económico, además de mejorar la percepción del contribuyente y generando incentivos en el pago de impuestos" (2011, p. 49)

Contudo, essa eficiência não parece estar ligada, de forma necessária, a fíliação dos instrumentos de execução a cobrança judicial ou administrativa.

Nesse sentido, o Uruguai, que se utiliza de um sistema judicial, vem se despontando como o país latino-americano com os melhores índices de evasão fiscal, tendo revertido um quadro em que aparecia como o pior colocado no ano de 2000. Por outro lado, o Peru, não 
obstante adotar sistema administrativo de cobrança do crédito tributário, permanece nas últimas posições do ranking, como um dos piores países em matéria de evasão ${ }^{12}$.

Certamente, o resultado positivo obtido pelo Uruguai decorre do Programa de Apoyo a la Gestión Tributaria, patrocinado pelo Banco Interamericano de Desenvolvimento, que, a partir de 2006, destinou recursos para o fortalecimento institucional do órgão arrecadador uruguaio (Dirección General Impositiva), tanto com capacitação e profissionalização de seu pessoal, como melhoramento da infra-estrutura; para a melhoria da qualidade de gestão, modernizando os sistemas e procedimentos de gestão por meio de emprego tecnológico, assistência ao contribuinte, controle tributário e adoção de um sistema de informação gerencial completo e tempestivo; para o fortalecimento da transparência e comunicação, no sentido de fortalecer a imagem institucional do órgão arrecadador, aproximando-a da sociedade, além de desenvolver programas de educação tributária ${ }^{13}$.

Por outro lado, o sistema brasileiro de execução judicial precisa, urgentemente, ser repensado, frente à grave ineficiência. Segundo recente estudo realizado pelo IPEA - Instituto de Pesquisa Econômica Aplicada (2011, p. 16), o custo médio total de uma ação de execução fiscal promovida pela Procuradoria da Fazenda Nacional junto à Justiça Federal é de R\$ 5.606,67, tendo como tempo médio total de tramitação 9 (nove) anos, 9 (nove) meses e 16 (dezesseis) dias, e uma probabilidade de obter-se a recuperação integral do crédito de $25,8 \%$. Com tais números, só seria economicamente justificável promover-se judicialmente o executivo fiscal de créditos que ultrapassassem $\mathrm{R} \$ 21.731,45$. É evidente que tal realidade não se sustenta e muito menos atende o postulado constitucional da eficiência.

Sob outro aspecto, a cobrança administrativa do crédito tributário nos moldes da Argentina, do Peru e da Espanha, além de não garantir, necessariamente, o atendimento ao princípio da eficiência, tende a afrontar o princípio da segurança jurídica e seus respectivos corolários da legalidade e do devido processo legal. Ora, ainda que se possam admitir atos administrativos que não sejam objeto de apreciação por parte do Poder Judiciário (o que não seria possível no Brasil em face da inafastabilidade prevista no art. $5^{\circ}$, inciso XXXV, da

\footnotetext{
${ }^{12} \mathrm{Tal}$ informação pode ser confirmada em estudo feito pelo órgão fazendário uruguaio (Dirección General Impositiva), disponível no endereço eletrônico: http://www.dgi.gub.uy/media/wdgi/EvasionIVAAmerica Latina.html Acesso em 05 de junho de 2016.

Ademais, a imprensa daquele país também noticiou a mudança: "La Dirección Nacional Impositiva (DGI) destacó que Uruguay va camino de ser por tercer año consecutivo el país de Latinoamérica con menor evasión fiscal, seguido de cerca por Chile, gracias al Nuevo Sistema Tributario de 2007." Notícia disponível em http://www.espectador.com/economia/237367/uruguay-lidera-nuevamente-en-eficiencia-fiscal Acesso em 05 de junho de 2016.

${ }_{13}$ Para maiores detalhes conferir: PROGRAMA DE APOYO A LA GESTIÓN TRIBUTARIA. Disponível em http://idbdocs.iadb.org/wsdocs/getdocument.aspx?docnum=816203 Acesso em 07 de junho de 2016.
} 
Constituição Federal ${ }^{14}$ ), não parece recomendável a possibilidade de se efetivar penhora sobre bens móveis e imóveis, assim como o bloqueio de valores monetários nas contas correntes, sem o prévio crivo Judicial. Em especial por se tratarem de atos em face da propriedade privada e pelo fato de que a atuação administrativa tende a parcialidade. Analogicamente, tal modelo alinha-se a um sistema inquisitivo, no qual o mesmo órgão que acusa é responsável por julgar.

\section{Conclusão}

A título de conclusão, espera-se que tenha restado evidenciada a necessidade de um fortalecimento da capacidade de fiscalização e da exigência coativa no cumprimento dos deveres tributários pelos cidadãos-contribuintes, em especial por parte das administrações tributárias na América Latina. Esse fortalecimento, contudo, só será possível mediante a modernização do sistema de arrecadação, melhoria da infra-estrutura e desburocratização jurídica. Outra forma de aprimoramento da gestão pode ser encontrada na desconcentração administrativa, seja por meio da criação de órgãos e entidades regionais e locais, como pela assinatura de convênios e cruzamento de informações entre os órgãos estatais, tudo a fim de atender o princípio da eficiência administrativa.

Por outro lado, na busca de tal eficiência, não se pode afastar a necessidade de que a formalização e cobrança do crédito tributário observem a sequência de atos administrativos ou processuais que as integram, de acordo com as regras estabelecidas na norma jurídica, com tratamento igualitário e imparcial, além de preservar o direito à ampla defesa e aplicação do contraditório. Entende-se que estas características não são incompatíveis com os princípios da economia, da celeridade procedimental, não podendo se admitir modelos de cobrança do crédito tributário que afastem ou flexibilizem estas garantias essenciais.

Sob outro aspecto, o contribuinte adimplente não possui nenhum interesse em sistemas de arrecadação e de execução ineficientes. Na verdade, a morosidade dos procedimentos torna instável a relação, prejudicando o interesse das partes envolvidas, sobretudo do contribuinte, que fica a mercê do Estado para a conclusão dos atos de sua competência. Sendo assim, é preciso equacionar o respeito aos atos previstos para o regular desenvolvimento procedimental, sem postergar injustificadamente o resultado final, já que a garantia do cidadão passa pela

\footnotetext{
${ }^{14}$ Não obstante o princípio da inafastabilidade, no Brasil, desde a década de 90, já existiram diversos Projetos de Lei visando definir métodos administrativos para execução fiscal. São eles: Projeto de Lei $\mathrm{n}^{\circ}$. 2412/2007, em tramitação na Câmara dos Deputados aguardando parecer do Relator na Comissão Especial; Projeto de Lei ${ }^{\circ}$. $7360 / 2002$, que restou arquivado perante a Câmara dos Deputados; Projetos de Lei $\mathrm{n}^{\circ} 75 / 2013, \mathrm{n}^{\mathrm{o}} 10 / 2005, \mathrm{n}^{\circ}$ 64/1999, no 608/1999, n 174/1996, todos arquivados no Senado Federal.
} 
conclusão rápida e eficaz do procedimento previsto pelas normas jurídicas. Em síntese, somente nas circunstâncias marcadas por esse equilíbrio pode-se dizer que houve o atendimento ao devido processo legal, garantindo a segurança jurídica e a própria eficiência administrativa.

\section{Referências bibliográficas}

BAER, Katherine. La administración tributaria en América Latina: Algunas Tendencias y Desafios. In: CETRÁNGOLO, Oscar; SABAINI, Juan Carlos Gómez (Comp.). Tributación en América Latina: En Busca de una Nueva Agenda de Reformas. Chile: Comision Econômica para América Latina y el Caribe (CEPAL), 2006. 36p. Disponível em: <http:// http://www.cepal.cl/publicaciones/xml/1/27951/lcg2324e_CapII.pdf $>$. Acesso em 20 de março de 2016.

BENZRIHEN, Jorge; VIGNALE, Jorge. Aspectos relacionados con la Administración Tributaria hacia una mayor eficiencia y equidad. In: O'CONNORY, Ernesto A.; VIGNALE, Jorge (Coord.) Sistema Tributario Argentino: un análisis comparativo de la contribución por sectores productivos y de la equidad sectorial. Universidade Católica Argentina, 2011. Disponível em http://www.uca.edu.ar/uca/common/grupo83/files/2011_Sistema_tributario_ argentino._Contribucion_por_sectores_productivos.pdf Acesso em 06 de junho de 2016.

BORGONOVO, Carlos Mario. La Ejecución Fiscal en la Argentina. Argentina: Instituto de Estudios de las Finanzas Publicas Argentinas, 34p. Disponível em: $<$ http://www.iefpa. org.ar/criterios_digital/monografias/borgonovo.pdf $>$. Acesso em 04 de fevereiro de 2008. BRONDOLO, John D. La deuda tributaria y la cobranza coactive. Washington. Departamento de Finanças Públicas. Fundo Monetário Nacional, 2001.

CAMPOS, Santiago Pereira; RODRIGUEZ, Clarisa. El Proceso Monitorio en Uruguay. Disponível em https:/www.academia.edu/12372120/EL_PROCESO_MONITORIO_EN_ URUGUAY Acesso em 04 de junho de 2016.

COBAS, Francisco; LENS, Hugo. Las Excepciones en el Juicio Ejecutivo Fiscal, con Especial Énfasis en la Inhabilidad de Título. Universidad de Montevideo, 2015. Disponível em: http://www.um.edu.uy/docs/tesisfder-las-excepciones-en-el-juicio-ejecutivo-fiscal-con- 
especial-enfasis-en-la-inhabilidad-de-titulo-cobas-francisco-lens-hugo.pdf Acesso em 05 de junho de 2016.

CONTI, Elizabeth A. El Nuevo Procedimiento de Ejecución Fiscal en la República Argentina. Argentina: Instituto de Estúdios de las Finanzas Publicas Argentinas (IEFPA), 57p. Disponível em: <http://www.iefpa.org.ar/criterios_digital/monografias/conti.pdf $>$. Acesso em 05 de fevereiro de 2008.

DI PIETRO, Maria Sylvia Zanella. Direito Administrativo. 14ª ed. São Paulo: Atlas, 2002.

FARIA, Edimur Ferreira de. Curso de Direito Administrativo Positivo. $8^{\text {a }}$ ed. Belo Horizonte:Fórum, 2015.

FERNÁNDEZ, Lucía, GARCÍA, Lorena y CAL, Maximiliano. El proceso monitorio uruguayo ¿Un ejemplo a seguir? In: RUDP 1/2014.

FONROUGE, Carlos M. Giuliani. Derecho financeiro. Volumen II. Actualizada por Susana Camila Navarrine y Rubén Oscar Asorey. $5^{\mathrm{a}}$ ed. Buenos Aires: Depalmas, 1993.

GODOY, Arnaldo Sampaio de Moraes. A execução fiscal na Espanha. Disponível em: http://www.arnaldogodoy.adv.br/artigos/execucaofiscalespanha.htm. Acesso em 25 de janeiro de 2018.

GOMES SANTORO, Fernando, Curso sobre La Reforma del Código General del Proceso (Ley 19.090). La Ley, 2015.

IPEA - Instituto de Pesquisa Econômica Aplicada. Custo e tempo do processo de execução fiscal promovido pela Procuradoria Geral da Fazenda Nacional. Brasília: novembro 2011. Disponível em: http://www.ipea.gov.br/agencia/images/stories/PDFs/nota_tecnica/111230_ notatecnicadiest1.pdf Acesso em 25 de março de 2016.

MEIRELLES, Hely Lopes. Direito Administrativo Brasileiro. São Paulo: Malheiros, 1996. SANTI, Alejandro. Principales modificaciones introducidas por la Ley n ${ }^{\circ} .19 .090$ al proceso ejecutivo. In: RUDP 1/2013. 
SILVA PACHECO, José da. Comentários à lei de execução fiscal: Lei Federal $n^{\circ} 6.830$, de 22-09-1980. 9a ed. São Paulo: Saraiva, 2002.

VARELA, Raul Junquera. Sistemas Tributarios Y Administración Tributaria en

Iberoamérica. Costa Rica: Agencia Estatal de Administración Tributaria, jan. 2001, 73p.

Disponível em: $<$ http:// www.hacienda.go.cr/centro/datos/Articulo/Sistemas\%20tributarios\% 20en\%20Iberoaméria.pdf $>$. Acesso em 05 de março de 2016.

VILLEGAS, Héctor B. Curso de finanzas, derecho financiero y tributario. $5^{\mathrm{a}}$ ed. Buenos Aires: Depalmas, 1995.

VIZCAÍNO, Catalina García. Derecho tributário. Tomo II. Buenos Aires: Depalmas, 1997. 


\title{
REIDI, PIS E COFINS E AS CONCESSIONÁRIAS DE ENERGIA: DA NECESSIDADE DE DAR EFETIVIDADE AO BENEFÍCIO FISCAL À LUZ DOS PRINCÍPIOS DO EQUILÍBRIO ECONÔMICO-FINANCEIRO E DA DURAÇÃO RAZOÁVEL DO PROCESSO
}

\author{
Alexandre Naoki Nishioka \\ Faculdade de Direito de Ribeirão Preto da Universidade de São Paulo (FDRP/USP) \\ Gabriel de Carvalho Thielmann \\ Universität Hamburg (UHH - Alemanha)
}

\begin{abstract}
Resumo
O REIDI (Lei $\left.n^{\circ} 11.488 / 2007\right)$ é um incentivo extrafiscal que visa estimular o desenvolvimento da infraestrutura nacional por meio da suspensão da exigência e posterior conversão em alíquota zero do PIS/PASEP e da COFINS incidentes sobre a venda e a importação de insumos e materiais de construção. Todavia, a Administração tem excedido o prazo para análise do requerimento de enquadramento das obras no REIDI, impedindo as empresas de gozar do benefício em tempo hábil, fazendo-se necessário o acionamento do Poder Judiciário para assegurar o direito à eficiência da Administração Pública e à razoável duração do procedimento administrativo.
\end{abstract}

Palavras-chave: REIDI, Incentivo Fiscal, Infraestrutura, Equilíbrio econômico-financeiro, Duração razoável do processo.

\section{Abstract/Resumen/Résumé}

REIDI (Law No. 11,488 / 2007) is a tax incentive that aims to stimulate the development of Brazil's infrastructure by suspending the requirement and subsequently converting into a zero rate of two taxes (PIS/PASEP and COFINS) levied on sales and imports of inputs and building materials. However, the Public Administration has been exceeding the deadline for reviewing the company's application for the incentive, preventing companies from enjoying the benefit in proper time, making it necessary to fill in a complaint in the Court to ensure the right to efficiency of Public Administration and to a trial within a reasonable time.

Keywords: REIDI, Tax Incentive, Infrastructure, Economic-financial balance, Trial within a reasonable time. 


\section{Introdução}

O modelo do setor elétrico brasileiro estabelecido nos dias de hoje é o resultado de inúmeras mudanças institucionais e operacionais ocorridas ao longo dos anos na política energética do país. Em especial, destacam-se as alterações decorrentes da implementação do processo de reformulação proposto pelo chamado RESEB - Projeto de Reestruturação do Setor Elétrico Brasileiro ocorrido em meados da década de 1990, que culminaram na desverticalização do sistema, evoluindo do cenário político-econômico de um Estado direta e fortemente ligado à atividade industrial como ente regulador e executor ao atual modelo, caracterizado pela existência de empresas privadas na geração, transmissão e, principalmente, na distribuição de energia, e de autarquias independentes na regulação do setor.

Em 02 de dezembro de 1997 foi criada a AGÊNCIA NACIONAL DE ENERGIA ELÉTRICA - ANEEL, autarquia em regime especial vinculada ao MINISTÉRIO DE MINAS E ENERGIA - MME, que regulamenta as políticas e diretrizes do Governo Federal para a utilização e exploração dos serviços de energia elétrica no país, estabelece padrões de qualidade do atendimento e de segurança nas operações, e calcula e define as necessidades de implantação de infraestrutura, de ampliação e reforço das linhas, analisando a viabilidade técnica, econômica e ambiental dessas ações, a fim de promover o uso eficaz e eficiente de energia elétrica e proporcionar condições para a livre competição nesse mercado.

A agência reguladora pratica três modalidades de regulação: $(i)$ a regulação técnica de padrões de serviço (geração, transmissão, distribuição e comercialização); (ii) a regulação econômica (tarifas e mercado); e (iii) a regulação dos projetos de pesquisa e desenvolvimento (P\&D) e de eficiência energética.

Especificamente em relação à regulação do serviço de transmissão de energia e dos projetos de manutenção, expansão e melhorias das linhas de transmissão, a ANEEL, juntamente com o MINISTÉRIO DE MINAS E ENERGIA, desempenha papel que influencia diretamente na forma de atuação das empresas do setor elétrico, estabelecendo diretrizes e determinando as políticas de expansão e melhoria da rede, e, principalmente, calculando a RECEITA ANUAL PERMITIDA - RAP dessas empresas, isto é, a remuneração que as transmissoras recebem pela prestação do serviço público de transmissão aos usuários.

Para o cálculo da RAP, há que se diferenciar entre as transmissoras que tiveram seus contratos de concessão renovados, para as quais a RAP é calculada com base nos custos de Operação e Manutenção, conforme estabelece a Lei n ${ }^{\circ}$ 12.783, de 11 de janeiro de 2013, quando 
da renovação, e aquelas participantes de processo licitatório, em que a RAP decorre do próprio leilão de transmissão, sendo paga às transmissoras a partir da entrada em operação comercial de suas instalações, e revista a cada quatro ou cinco anos, nos termos dos contratos de concessão. Por fim, há ainda casos em que a ANEEL verifica a necessidade de reforços ou ampliação na rede de transmissão em contratos já existentes, casos nos quais um valor adicional à RAP é calculado por meio de uma Resolução Autorizativa com o fito de remunerar as novas instalações ${ }^{1}$.

Em 2007, no contexto do Programa de Aceleração do Crescimento da Economia PAC, de iniciativa do Governo Federal, foi criado o Regime Especial de Incentivos para o Desenvolvimento da Infraestrutura - REIDI, por meio da Lei $\mathrm{n}^{\circ} 11.488$, de 15 de junho de 2007, com a finalidade de estimular o desenvolvimento da infraestrutura do país em diversos setores da economia, entre eles o de energia.

Referido regime especial incentiva a implantação de projetos de infraestrutura pelas empresas por meio da suspensão da exigência da Contribuição para o Programa de Integração Social e de Formação do Patrimônio do Servidor Público - PIS/PASEP e da Contribuição para o Financiamento da Seguridade Social - COFINS incidentes sobre a venda ou a importação de máquinas, aparelhos, instrumentos e equipamentos novos, e de materiais de construção para utilização ou incorporação em obras de infraestrutura destinadas ao ativo imobilizado dessas empresas, e posteriormente pela conversão dessa suspensão em alíquota 0 (zero), após a utilização ou incorporação do bem ou material de construção na obra de infraestrutura.

Isto é, o benefício do REIDI pode ser visto como o não pagamento pelas concessionárias dos valores referentes a PIS/PASEP e COFINS na compra de máquinas, equipamentos, materiais etc. para implantarem projetos de infraestrutura no país, não embutindo os fornecedores a alíquota das contribuições nos preços dos produtos vendidos aos empreendedores com essa finalidade.

Dessa forma, o REIDI proporciona uma redução considerável do custo inicial dos investimentos em obras de infraestrutura, o que acaba por atrair investimentos privados e beneficiar pessoas diversas, não só as beneficiárias diretas do regime, mas também aquelas que auferem receitas decorrentes da execução das obras de construção civil ou de reforço, melhoria, ampliação etc. do sistema elétrico nacional e terceiros relacionados a essas obras, como

\footnotetext{
${ }^{1}$ SGT ANEEL, publicado em 25 de novembro de 2015, modificado em 02 de março de 2016. Disponível em http://www.aneel.gov.br/calculo-tarifario-e-metodologia/-/asset_publisher/6pqBPPJq59Ts/content/receitaanualpermitida-rap/654800?inheritRedirect=false. Acesso em 12 de maio de 2018.
} 
trabalhadores e comerciantes nos arredores das obras, indústrias de peças, matérias primas, ferramentas, empresas de transporte de cargas e pessoas, bancos de investimento etc.

Ocorre que este incentivo não vem sendo concedido da forma como deveria às empresas que se dispõem a realizar as obras de infraestrutura requeridas pela ANEEL e que empenham consideráveis valores nessas obras ${ }^{2}$, atendendo ao desígnio da norma extrafiscal, como se verá adiante.

\section{Objetivo}

O presente estudo tem como objetivo apresentar de forma simplificada ao leitor o benefício fiscal do Regime Especial de Incentivos para o Desenvolvimento de Infraestrutura REIDI, previsto na Lei $\mathrm{n}^{\mathrm{o}} 11.488 / 2007$, traçando um panorama geral acerca do seu funcionamento, seus beneficiários e os requisitos necessários à sua concessão, a fim de facilitar o seu entendimento e permitir a identificação dos problemas procedimentais a ele relacionados.

O trabalho visa demonstrar, destarte, como as concessionárias transmissoras de energia elétrica podem ter acesso ao incentivo do REIDI de forma estratégica e eficiente, bem como os problemas relacionados à obtenção e ao gozo deste benefício que elas encontram ao longo do caminho.

Em especial, busca evidenciar as dificuldades encontradas pelas empresas nesse processo de obtenção do benefício fiscal, com a burocracia excessiva, inúmeras etapas do procedimento que poderiam ser eliminadas, e, principalmente, com o tempo desarrazoado que se despende visando alcançar o incentivo, oferecendo soluções para tais problemas e sugerindo um caminho mais curto e promissor que leva ao resultado almejado de forma rápida e eficiente.

\section{Metodologia}

A pesquisa se inicia com um caráter eminentemente teórico, com ênfase em perspectivas qualitativas e compreensivas do regramento jurídico aplicável ao caso concreto, considerando o objetivo precípuo do estudo de analisar a legislação que rege o benefício fiscal do REIDI, identificar os obstáculos procedimentais criados por esse regramento, e encontrar soluções para superá-los de maneira eficiente.

\footnotetext{
2 Não se trata unicamente de atividade discricionária da empresa de ampliar, melhorar ou reforçar sua infraestrutura, mas muitas vezes vinculada ao requerimento da agência reguladora do setor.
} 
Num segundo momento, compara-se a situação de cada uma das partes envolvidas na relação jurídica decorrente do incentivo fiscal sob o prisma dos princípios constitucionais da segurança jurídica, da igualdade, da moralidade administrativa e do equilíbrio econômicofinanceiro. Parte-se de um estudo bibliográfico da literatura nacional, especialmente da doutrina relacionada à atuação da Administração Pública na relação com o particular, para abordar os princípios constitucionais e administrativos que regem essa atuação, buscando a explanação para os conceitos relevantes desta etapa.

Analisam-se, ainda, a duração razoável do processo administrativo e as consequências do silêncio da Administração Pública sob a ótica do dever de manifestação em tempo razoável diante dos pedidos do administrado, tanto por meio do estudo da legislação pura e simples, como pelas opiniões doutrinárias acerca do tema e pela jurisprudência pátria.

Por fim, o trabalho é encerrado com uma proposta de solução para os problemas encontrados na obtenção do benefício fiscal, conciliando o interesse público com o particular, extraindo a conclusão da própria legislação e da posição jurisprudencial consolidada nos dias de hoje, que permitem ao jurisdicionado buscar auxílio na Justiça e obter o remédio adequado para o problema a que está exposto.

\section{Desenvolvimento}

\subsection{O Regime Especial de Incentivos para o Desenvolvimento da Infraestrutura - REIDI}

A Lei $n^{\circ}$ 11.488/2007, que cria o REIDI, e o Decreto no 6.144, de 03 de julho de 2007, que regulamenta a forma de habilitação e co-habilitação ao referido regime, preveem um procedimento a ser seguido tanto pelo Poder Público como pelas empresas, para que estas façam jus ao benefício e desenvolvam a infraestrutura nacional.

Todavia, atualmente este procedimento vem sendo seguido adequadamente apenas pelas concessionárias, que cumprem os prazos, respeitam os cronogramas e preenchem os requisitos estabelecidos pela ANEEL e pelo MINISTÉRIO DE MINAS E ENERGIA quando da execução das obras, enquanto o Poder Público deixa de cumpri-lo, desrespeitando diversos princípios e garantias constitucionais e direitos positivados, o que tem acarretado enormes prejuízos para as empresas do setor de energia. Explica-se.

O procedimento para a declaração do benefício fiscal do REIDI segue o seguinte fluxograma (Lei n ${ }^{\circ}$ 11.488/07, Decreto $n^{\circ}$ 6.144/07 e Instrução Normativa RFB nº 758/07): 


\section{RESOLUÇÃO AUTORIZATIVA - REA}

É expedida pela agência reguladora determinando a implantação de reforços em instalações ou a construção de linhas sob responsabilidade da concessionária de serviço público de transmissão de energia elétrica, com prazo para início da operação comercial previsto na Resolução e contado a partir da data de sua publicação.

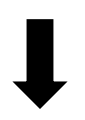

\section{PROJETO}

É enviado à ANEEL pelas concessionárias a partir da publicação da REA, com a previsão do necessário para a execução das instalações, respeitando os prazos de implantação estabelecidos na Resolução e solicitando o enquadramento no REIDI (comprovação dos requisitos para o benefício).

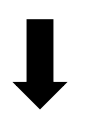

\section{ANÁLISE PELA ANEEL}

Da adequação do projeto aos termos da Lei e da Regulamentação do REIDI e a conformidade dos documentos apresentados, encaminhando o processo devidamente instruído ao Ministério de Minas e Energia - MME, contendo uma Nota Técnica com manifestação expressa acerca da adequação do pleito e do enquadramento no REIDI, da conformidade do projeto e dos documentos apresentados, inclusive quanto à razoabilidade das estimativas dos investimentos, com base em valores regulatórios equivalentes, e do valor de suspensão dos impostos e contribuições decorrente do REIDI.

\section{】}

ANÁLISE PELO MINISTÉRIO DE MINAS E ENERGIA - MME

Do processo encaminhado pela ANEEL, aprovado u não o projeto no REIDI.

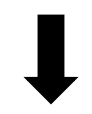

\section{PORTARIA DE APROVAÇÃO}

Específica do Ministério é publicada no Diário Oficial da União no caso de aprovação do projeto, contendo as estimativas dos investimentos e da suspensão dos impostos e contribuições decorrente do REIDI. 
I

\section{PEDIDO DE HABILITAÇÃO}

É feito pela concessionária junto à Receita Federal do Brasil - RFB do benefício do REIDI (suspensão do pagamento de PIS/PASEP e COFINS), tão somente para que verifique sua regularidade fiscal referente aos impostos e às contribuições administrados pela RFB.

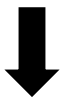

\begin{tabular}{l}
\hline \multicolumn{1}{|c|}{ DESPACHO DA RECEITA FEDERAL } \\
\hline É proferido deferindo ou indeferindo o pedido de habilitação ao benefício do REIDI, e dando \\
ciência ao contribuinte.
\end{tabular}

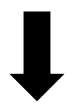

\begin{tabular}{|l|}
\hline \multicolumn{1}{|c|}{ ATO DECLARATÓRIO EXECUTIVO } \\
\hline É emitido pelo Delegado da Delegacia da Receita Federal - RFB ou da Delegacia da Receita \\
Federal de Administração Tributária - DERAT e publicado no Diário Oficial da União, \\
formalizando a habilitação no REIDI e concedendo o benefício. \\
\hline
\end{tabular}

A Resolução Autorizativa - REA expedida pela ANEEL, primeiro ato praticado no procedimento descrito acima, traz em seus dispositivos e anexos a descrição das obras de infraestrutura que deverão ser realizadas pelas concessionárias, sob sua própria responsabilidade, bem como o prazo para o término dessas obras e início da operação comercial, a contar da data da publicação da Resolução.

Dentro desse prazo estabelecido pela própria agência, as concessionárias devem demonstrar, por meio de projeto enviado à ANEEL, que as obras a serem realizadas $(i)$ são de infraestrutura, (ii) que se enquadram no benefício do REIDI, e, principalmente, (iii) que preveem que os custos do empreendimento foram estimados levando em consideração a suspensão do recolhimento de PIS/PASEP e COFINS permitidos pelo regime de incentivo (impacto da aplicação do REIDI), em respeito ao art. $6^{\circ}$, inciso I, do Decreto $\mathrm{n}^{\circ} 6.144 / 07$, in verbis: 
Art. $6^{\circ}$. O Ministério responsável pelo setor favorecido deverá definir, em portaria, os projetos que se enquadram nas disposições do art. $5^{\circ}$.

$\S 1^{\circ}$ Para efeitos do caput, exclusivamente nos casos de projetos com contratos regulados pelo Poder Público:

I - os Ministérios deverão analisar se os custos do projeto foram estimados levando-se em conta a suspensão prevista no art. $2^{\mathbf{o}}$, inclusive para cálculo de preços, tarifas, taxas ou receitas permitidas, sendo inadmissíveis projetos em que não tenha sido considerado o impacto da aplicação do REIDI; [...] [destacou-se]

Ou seja, desde a etapa do projeto, as concessionárias já devem "descontar" o valor do benefício do REIDI de suas receitas, e também passam a executar as obras de infraestrutura determinadas pela ANEEL, pois são obrigadas a seguir o cronograma que é encaminhado à agência e a cumprir com a execução completa das instalações, sejam meros reforços ou construção de novas linhas, invariavelmente dentro do prazo estipulado, sob pena de sofrerem as sanções previstas na legislação, como a revogação de suas autorizações, prevista no art. 11, $\S 1^{\circ}$, inciso I, da Resolução Normativa ANEEL n 63 , de 12 de maio de 2004, in verbis:

Art. 11. Constituem infrações, sujeitas à penalidade de revogação de autorização, aquelas previstas na legislação e nos atos autorizativos que, a critério da ANEEL, impliquem prejuízo considerável ao desenvolvimento das atividades autorizadas e/ou configurem sistemática inadimplência do seu titular, especialmente nas hipóteses de: I - descumprimento de cronogramas, obrigações e encargos decorrentes da autorização; [...] [destacou-se]

Para atender ao escopo da norma extrafiscal do REIDI (Lei $\mathrm{n}^{0} 11.488 / 07$ ), o procedimento acima descrito deveria ser cumprido integralmente por ambas as partes envolvidas, concessionárias e Poder Público, dentro do prazo estipulado pela ANEEL, garantindo-se o sinalagma da relação jurídica, sob pena de não ter a eficácia devida e de se tornar desfavorável para uma das partes, o que vem ocorrendo nos dias de hoje.

\subsection{Do princípio do equilíbrio econômico-financeiro na relação jurídica do Poder Público com as transmissoras de energia elétrica}

Como se salientou acima, o que se tem verificado hoje é um desequilíbrio econômico na relação jurídica do particular com o Poder Público ${ }^{3}$, em que as concessionárias estão sendo obrigadas a realizar as obras de infraestrutura dentro do prazo estipulado pela agência

\footnotetext{
${ }^{3}$ A relação jurídica de que se trata é de natureza regulamentar e contratual, em decorrência dos contratos de concessão firmados entre as partes, em que as empresas assumem o papel de concessionárias de um serviço público essencial, in casu a transmissão de energia elétrica, e a Administração o encargo de remunerá-las pelo serviço prestado, seja diretamente ou mediante tarifas cobradas dos usuários do serviço.
} 
reguladora, calculando os valores dos projetos considerando o impacto da aplicação do REIDI, e despendendo com "matéria prima" e força-trabalho para cumpri-los, sem a devida contrapartida do benefício fiscal que lhes é assegurado por lei, por mera desídia do Poder Público, em nítida violação ao princípio do equilíbrio econômico-financeiro que rege a relação entre as partes.

Nessa linha, BANDEIRA DE MELO (2009, p. 696) ensina que

[...] a concessão de serviço público é o instituto através do qual o Estado atribui o exercício de um serviço público a alguém que aceita prestá-lo em nome próprio, por sua conta e risco, nas condições fixadas e alteráveis unilateralmente pelo Poder Público, mas sob garantia contratual de um equilíbrio econômico-financeiro, remunerando-se pela própria exploração dos serviços, em geral e basicamente mediante tarifas cobradas diretamente dos usuários do serviço.

Ou seja, o Poder Público transfere a execução do serviço para o particular, conservando sua titularidade, de modo que mantém a disponibilidade e o controle sobre este serviço, fiscalizando-o, aplicando sanções nos casos de mau funcionamento ou de descumprimento das condições preestabelecidas, determinando a realização de melhorias, ampliações etc., tudo isto unilateralmente, sem a interferência do concessionário, que só se manifesta quanto às condições de sua remuneração.

Dito isto, importa definir o que vem a ser equilíbrio econômico-financeiro nessa relação jurídica formada pelo contrato de concessão, com o fito de evidenciar a condição de desequilíbrio que se apontou acima. E coube à doutrina conceituar o instituto, diante da lacuna legislativa do ordenamento pátrio nesse aspecto.

Para JUSTEN FILHO (2013, p. 548 e 830), é a “[...] relação entre encargos e vantagens assumidas pelas partes do contrato administrativo, estabelecida por ocasião da contratação, e que deverá ser preservada ao longo da execução do contrato.” Ensina ainda o autor que nos contratos de concessão deve haver uma "equivalência honesta entre aquilo que é atribuído ao concessionário e aquilo que dele é exigido", sendo o que ele chama de "equivalência financeira e comercial, a equação financeira do contrato de concessão."

Por sua vez, WALD (2004, p. 68) pondera que

[...] o dever ético de garantir a manutenção da equação econômica e financeira é também um dever jurídico da administração direta ou indireta, como corolário específico do princípio constitucional, que não admite o sacrifício dos interesses particulares em proveito do interesse público, vedando-se a desapropriação não só de bens móveis ou imóveis, mas de qualquer direitos ou créditos sem a prévia e justa indenização paga em dinheiro (art. $5^{\circ}$, inc. XXIV, da Constituição vigente). 
Desta feita, extrai-se que o equilíbrio econômico e financeiro de um contrato de concessão de serviço público é o resultado de uma equação complexa que se estabelece entre o Poder Público e o concessionário, cuja equivalência entre encargos e vantagens não pode ser modificada desproporcional e imotivadamente, sob pena de violação à segurança jurídica, à igualdade, à moralidade administrativa e ao princípio constitucional do equilíbrio econômicofinanceiro. Nesse sentido, prevê o art. 37, inciso XXI, da Constituição da República, in verbis:

Art. 37. A administração pública direta e indireta de qualquer dos Poderes da União, dos Estados, do Distrito Federal e dos Municípios obedecerá aos princípios de legalidade, impessoalidade, moralidade, publicidade e eficiência e, também, ao seguinte:

$[\ldots]$

XXI - ressalvados os casos especificados na legislação, as obras, serviços, compras e alienações serão contratados mediante processo de licitação pública que assegure igualdade de condições a todos os concorrentes, com cláusulas que estabeleçam obrigações de pagamento, mantidas as condições efetivas da proposta, nos termos da lei, o qual somente permitirá as exigências de qualificação técnica e econômica indispensáveis à garantia do cumprimento das obrigações. [destacou-se]

Evidencia-se, portanto, o desequilíbrio econômico-financeiro existente na relação jurídica ora examinada: a Administração Pública, exercendo o seu poder regulamentar, vem se beneficiando nos dois extremos da relação jurídica com o particular, pois determina que ele realize diversas obras para o desenvolvimento de sua própria infraestrutura, mantendo e ampliando os serviços de transmissão de energia elétrica nacionais, e ainda exige que ele desembolse considerável quantia para o pagamento de tributos dos quais teoricamente foi desonerado por força de lei, e dos quais a Fazenda Nacional é sujeito ativo.

O benefício do REIDI, inserido no contexto do Programa de Aceleração do Crescimento econômico brasileiro, possui um propósito extrafiscal de incentivo ao desenvolvimento da infraestrutura do país. Isto é, não visa à arrecadação, mas a um objetivo distinto, que traz benefícios ao Estado e à coletividade em forma de recursos produtivos, e nesse sentido não deveria ser obstado ou dificultado o seu acesso, e sim o contrário.

Dever-se-ia permitir às concessionárias o quanto antes o direito à suspensão da cobrança das contribuições ao PIS/PASEP e COFINS, para que possam adquirir máquinas, equipamentos, materiais de construção etc. para utilização ou incorporação nas obras de infraestrutura requeridas pelo Poder Público, reduzindo, assim, o custo inicial de seus investimentos, e estimulando a elas próprias e aos demais beneficiários secundários na execução dessas obras, que trazem benefícios a ambas as partes da relação jurídica. 
Não é o que ocorre. Atualmente, o Poder Público prevê um incentivo fiscal que atende ao escopo extrafiscal de desenvolvimento nacional, exige a realização de diversas obras levando em consideração o impacto do benefício concedido e em prazos preestabelecidos e inalteráveis, cujo descumprimento acarreta sanções rigorosas, mas não confere efetividade a este incentivo, muitas vezes mitigando-o ou até mesmo obstando o acesso a ele, o que gera um desequilíbrio econômico-financeiro em desfavor do particular, que se vê em posição de desvantagem em uma relação que deveria ser harmoniosa, em busca da equivalência.

Portanto, é evidente a violação ao princípio do equilíbrio econômico-financeiro na relação jurídica ora analisada, sendo cogente restabelecer essa condição de equilíbrio, tornando equânime novamente a relação, em respeito aos princípios constitucionalmente previstos da segurança jurídica, da igualdade, da moralidade administrativa e do equilíbrio econômicofinanceiro.

\subsection{Da razoável duração do processo administrativo}

Sabe-se que o princípio da duração razoável do processo administrativo está previsto expressamente na Constituição da República, em seu art. 5º inciso LXXVIII, segundo o qual “a todos, no âmbito judicial e administrativo, são assegurados a razoável duração do processo e os meios que garantam a celeridade de sua tramitação."

A expressão do princípio da duração razoável do processo como direito fundamental enfatiza a eficiência que vincula a atuação da administração pública, especificamente quanto à questão processual no âmbito administrativo, conferindo a todos a sua razoável duração e os meios que garantam a celeridade de sua tramitação. A demora excessiva na apreciação de determinado pleito administrativo, antes de qualquer coisa, fere o princípio da eficiência, preconizado no art. 37 da Constituição Federal, in verbis:

Art. 37. A administração pública direta e indireta de qualquer dos Poderes da União, dos Estados, do Distrito Federal e dos Municípios obedecerá aos princípios da legalidade, impessoalidade, moralidade, publicidade e eficiência [...]

Na lição de MEDAUAR (2007, p. 127), 
a eficiência é princípio que norteia toda a atuação da Administração Pública. [...] o princípio da eficiência determina que a Administração deve agir, de modo rápido e preciso, para produzir resultados que satisfaçam as necessidades da população. Eficiência contrapõe-se a lentidão, a descaso, a negligência, a omissão [...].

Como visto anteriormente no fluxograma para a concessão do benefício, o primeiro passo é a expedição de uma resolução autorizativa pela ANEEL solicitando às concessionárias a realização de melhorias em determinadas linhas de transmissão, reforços, ampliação, ou que implantem algum novo projeto de infraestrutura. Em seguida, tem-se a resposta das empresas, apresentando o projeto requerido pelo Poder Público, comprovando o preenchimento dos requisitos para o gozo do benefício, e requerendo o seu enquadramento no regime especial, o que é seguido pela análise da ANEEL da adequação do projeto aos termos da Lei e da Regulamentação do REIDI e da conformidade dos documentos apresentados.

Feita essa análise do cumprimento dos requisitos legais, é expedida nota técnica pela ANEEL com manifestação expressa acerca da adequação do pleito e do enquadramento no REIDI, da conformidade do projeto e dos documentos apresentados, inclusive quanto à razoabilidade das estimativas dos investimentos, com base em valores regulatórios equivalentes, e do valor de suspensão dos impostos e contribuições decorrente do REIDI (art. $2^{\circ}, \S 2^{\circ}$, da Portaria ANEEL n ${ }^{\circ} 274$, de 19 de agosto de 2013), sendo então remetido o processo ao Ministério de Minas e Energia - MME para um procedimento formal de aprovação do projeto no REIDI.

Todavia, esta última etapa mencionada é a que gera mais contratempos, seja por ser meramente formal, tendo em vista que a agência reguladora, com a expedição da nota técnica, já verificou precisamente o preenchimento dos requisitos e o enquadramento do projeto no REIDI, momento a partir do qual já poderiam as concessionárias usufruir do benefício, seja porque é a mais morosa, na qual inúmeros processos não "saem do lugar", aguardando desnecessariamente por meses sem serem apreciados, enquanto os prazos das obras se esgotam e o benefício que deveria servir para reduzir os custos de investimento e incentivar a realização das obras não é concedido.

O Ministério de Minas e Energia, neste procedimento burocrático, dúplice e moroso ${ }^{4}$, analisa novamente toda a documentação enviada pelas empresas à ANEEL para expedir a Portaria de Aprovação. E não fosse suficiente, ainda há, por fim, uma terceira análise pela

\footnotetext{
${ }^{4}$ Verifica-se que o procedimento do Ministério de Minas e Energia é absolutamente despiciendo pela própria disposição constante no art. $2^{\circ}$, caput, e $\S \S 1^{\circ}$ e $2^{\circ}$, da Portaria MME n ${ }^{\circ} 274$, de 19 de agosto de 2013.
} 
Receita Federal, também estritamente formal, que verifica tão somente a regularidade fiscal referente aos tributos federais das empresas, para só então ser declarado o benefício.

Ora, a regularidade fiscal das transmissoras de energia é quase que presumida, visto se tratar de empresas sujeitas às regras da Lei $\mathrm{n}^{0}$ 8.631, de 04 de março de 1993, que determina a obrigatoriedade de as concessionárias de serviço público não possuírem dívidas com o Poder Público, sob pena de não terem acesso à RAP, bem como diante da fiscalização rigorosa que é comum ao mercado de capitais e seus investidores, de forma que não podem deixar de ter regularidade fiscal. E ainda que assim não fosse, a regularidade pode ser facilmente comprovada por outros meios, como com a apresentação de certidões de regularidade físcal, sendo despicienda uma etapa do procedimento exclusivamente para isso.

Ressalte-se, por oportuno, que são valores consideráveis desembolsados pelas empresas a título de PIS/PASEP e COFINS para realizar os projetos requeridos pela ANEEL, muito embora sejam obrigadas a fazer os cálculos dos projetos já considerando o impacto do REIDI, mesmo sem ter acesso imediato ao benefício.

Não se justifica tamanha ineficiência do Poder Público com o administrado, haja vista serem vedadas quaisquer condutas das quais decorram atrasos desnecessários ou alheios à razoabilidade, nos assuntos colocados sob sua apreciação. Este, inclusive, é o entendimento da jurisprudência pátria em relação à matéria:

ADMINISTRATIVO. APOSENTADORIA. ATRASO NA CONCESSÃO. INDENIZAÇÃO. PRINCÍPIOS CONSTITUCIONAIS. ART. 49 DA LEI N ${ }^{\circ}$ 9.784/99. 1. Ao processo administrativo devem ser aplicados os princípios constitucionais insculpidos no artigo 37 da Carta Magna.

2. É dever da Administração Pública pautar seus atos dentro dos princípios constitucionais, notadamente pelo princípio da eficiência, que se concretiza também pelo cumprimento dos prazos legalmente determinados. $[\ldots]^{5}$ [destacouse]

MANDADO DE SEGURANÇA. ANISTIA. INTERPOSIÇÃO DE RECURSO ADMINISTRATIVO. DEMORA NA RESPOSTA. PRAZO RAZOÁVEL PARA APRECIAÇÃO. INCIDÊNCIA DO PRINCÍPIO CONSTITUCIONAL DA EFICIÊNCIA E DA GARANTIA À DURAÇÃO RAZOÁVEL DO PROCESSO. OMISSÃO CONFIGURADA. APLICAÇÃO SUBSIDIÁRIA DO ART. 49 DA LEI N. 9.784/99. [...]

3. Não é lícito à Administração Pública prorrogar indefinidamente a duração de seus processos, pois é direito do administrado ter seus requerimentos apreciados em tempo razoável, $e x$ vi dos arts. $5^{\circ}$, LXXIII, da Constituição Federal e $2^{\circ}$ da Lei n. 9.784/99. $[\ldots]^{6}$ [destacou-se] 
ADMINISTRATIVO. MANDADO DE SEGURANÇA. ATO OMISSIVO.

AUTORIZAÇÃO. EXECUÇÃO de SERVIÇOS DE RADIODIFUSÃO COMUNITÁRIA. 1. O exercício da atividade administrativa está submetido ao princípio da eficiência, nos termos do art. 37, caput, CF/88. 2. Configura-se ofensiva ao princípio da eficiência a conduta omissiva da autoridade competente, que deixa transcorrer longo lapso temporal sem processar pedido de autorização de funcionamento de rádio comunitária. 3. Ordem parcialmente concedida. ${ }^{7}$ [destacou-se]

Na mesma linha, o Poder Judiciário, por inúmeras vezes, já reconheceu que o silêncio administrativo configura abuso, e que a duração razoável do processo é direito fundamental do cidadão. Veja-se:

\begin{abstract}
CONSTITUCIONAL, ADMINISTRATIVO E TRIBUTÁRIO. MANDADO DE SEGURANÇA. PROCEDIMENTO ADMINISTRATIVO. PEDIDO DE REVISÃO DE DÉBITOS INSCRITOS EM DÍVIDA ATIVA. PRAZO RAZOÁVEL PARA CONCLUSÃO. DIREITO FUNDAMENTAL. ART. $5^{\circ}$, LXXVIII, DA CONSTITUIÇÃO FEDERAL. PRINCÍPIO DA EFICIÊNCIA. RECONHECIMENTO DA INEXISTÊNCIA DE DÉBITOS PELA AUTORIDADE IMPETRADA.
\end{abstract}

1. “A todos, no âmbito judicial e administrativo, são assegurados a razoável duração do processo e os meios que garantam a celeridade de sua tramitação." (Constituição Federal, art. $5^{\circ}$, inciso LXXVIII, incluído pela Emenda Constitucional $\left.n^{\circ} 45 / 2004\right)$.

2. O princípio da eficiência determina que a atividade administrativa seja desenvolvida com fins à satisfação das necessidades dos administrados, traduzindo-se na qualidade dos serviços públicos prestados. [...]

4. A conclusão dos procedimentos administrativos não pode ser postergada indefinidamente. $O$ silêncio da Administração, nesse caso, caracteriza abuso a ser corrigido mediante a concessão de ordem para determinar à autoridade impetrada a conclusão dos processos em prazo razoável.

5. No presente caso, a demora na verificação da regularidade fiscal do impetrante não pode obstar a consecução de suas atividades, mormente se a própria autoridade impetrada reconhece a inexistência de débito. 6 . Remessa oficial improvida. ${ }^{8}$ [destacou-se]

BANDEIRA DE MELO (2009, p. 410), analisando o tema, ensina que:

\footnotetext{
${ }^{7}$ STJ, $1^{\text {a }}$ Seção, MS n n 7.765-DF, Rel. Min. PAULO MEDINA, DJe 14.10.02.

${ }^{8}$ TRF-2. MS n ${ }^{\circ}$ 200651010238906, Rel. Des. PAULO BARATA. DJe 29.09.2007.
} 
O ordenamento pátrio repudia a inércia da Administração Pública, o que se observa a partir dos diversos dispositivos constitucionais e legais positivados que impõem à Administração o dever de manifestação diante dos pedidos do administrado. Como exemplo, cita-se o art. 116 da Lei $\mathrm{n}^{\circ}$ 8.112, de 11 de dezembro de 1990, que disciplina o regime jurídico dos servidores civis da União, o qual comina expressamente deveres aos agentes públicos, tendentes a viabilizar a realização dos direitos dos jurisdicionados, ao consignar que

[s]ão deveres do servidor: [...] V - atender com presteza: a) ao público em geral, prestando as informações requeridas, ressalvadas as protegidas por sigilo; b) à expedição de certidões requeridas para defesa de direito ou esclarecimento de situações de interesse pessoal.

Nesse cenário, diante de um quadro de injustificado retardamento, não resta outra alternativa ao administrado senão se valer do socorro ao Poder Judiciário para assegurar seu direito à eficiência da Administração Pública e à razoável duração do procedimento administrativo.

Em se tratando de uma omissão do Poder Público, que gera um desequilíbrio econômico-financeiro na relação jurídica firmada com o particular, cumpre ao Poder Judiciário dar solução à questão. É o que se depreende do acórdão proferido pelo Tribunal Regional Federal da $2^{\mathrm{a}}$ Região, in verbis:

ADMINISTRATIVO - PROCESSUAL CIVIL - INOCORRÊNCIA DA PRESCRIÇÃO - TRANSPORTE RODOVIÁRIO INTERESTADUAL - PEDIDO DE AUTORIZAÇÃO - SILÊNCIO DA ADMINISTRAÇÃO PÚBLICA. [...] O art. 21, XII, da CF, estabelece como competência da União a exploração, direta ou através de autorização, concessão ou permissão dos serviços de transporte rodoviário interestadual e internacional de passageiros. - A necessidade de licitação pública prevista do art. 175 da Constituição Federal, apesar de ser, em tese, justa e necessária, não se aplica ao caso. - Havendo omissão por parte da autoridade administrativa mesmo quando preenchidas todas as condições objetivas, esta pode ser suprida pelo Judiciário. - Inocorrência de ofensa a qualquer princípio, tendo em vista que cabe ao Judiciário conhecer sobre qualquer lesão ou ameaça a direito, como expresso no art. $5^{\circ}, \mathrm{XXXV}$, da Constituição Federal, não havendo limitação para o conhecimento da matéria submetida, desde que presente uma ilegalidade. - Apelação improvida. Sentença confirmada. ${ }^{9}$ [destacou-se]

Em juízo de cognição sumária, a solução à problemática está na determinação da suspensão da exigibilidade do PIS/PASEP e da COFINS incidentes sobre os projetos de infraestrutura requeridos pela ANEEL, nos termos do art. 151, V, do Código Tributário

\footnotetext{
${ }^{9}$ TRF-2. AC no 199902010363418, Relator FRANCISCO PIZZOLANTE, DJe 17.05.2002.
} 
Nacional ${ }^{10}$, a partir do momento em que a agência reguladora certificar o preenchimento dos requisitos para o enquadramento no REIDI (expedição da nota técnica ao MME), sob condição resolutiva de sua ulterior declaração, evitando-se assim que as empresas incorram nos prejuízos decorrentes do desembolso antecipado dos tributos, e devolvendo-se o equilíbrio econômicofinanceiro à relação jurídica estabelecida com o Poder Público.

Por sua vez, em cognição exauriente, a solução é que seja atribuída eficácia declaratória ao Ato Declaratório Executivo - ADE expedido pela Delegacia da Receita Federal ou pela Delegacia da Receita Federal de Administração Tributária que formalizar a habilitação dos projetos no REIDI, mantendo a desobrigação de recolhimento dos tributos acima referidos.

Como o próprio nome diz, trata-se de ato declaratório, que simplesmente reconhece uma situação preexistente ao final do procedimento administrativo, qual seja, o direito ao não recolhimento dos tributos referentes ao benefício do REIDI diante do preenchimento dos requisitos legais para o seu gozo.

Tais medidas conciliam o tempo do contribuinte com o tempo da Administração sem infringir o princípio da igualdade. Conciliam também o interesse público com os princípios do equilíbrio econômico-financeiro, da segurança jurídica, da proporcionalidade e razoabilidade, e, principalmente, da razoável duração do processo, indispensáveis no Estado de Direito.

Destarte, referidas medidas atendem plenamente ao escopo da norma extrafiscal, permitindo às empresas usufruir do benefício fiscal caso cumpram os requisitos exigidos pela legislação, e consequentemente levam ao desenvolvimento da infraestrutura do país almejada pelo Estado.

\section{Conclusão}

O Regime Especial de Incentivos para o Desenvolvimento da Infraestrutura - REIDI foi criado pela Lei $\mathrm{n}^{\mathrm{o}} 11.488$ no ano de 2007 com a finalidade precípua de estimular o desenvolvimento da infraestrutura do país, incentivando a implantação ou a expansão de projetos de infraestrutura nacionais por meio da suspensão da exigência e posterior conversão em alíquota zero do PIS/PASEP e da COFINS incidentes sobre a venda ou a importação de insumos e materiais de construção para utilização ou incorporação nessas obras.

Nesse sentido, revela um caráter extrafiscal importantíssimo no incentivo ao desenvolvimento econômico do país, proporcionando uma redução considerável do custo inicial

\footnotetext{
${ }^{10}$ Art. 151. Suspendem a exigibilidade do crédito tributário: [...] V - a concessão de medida liminar ou de tutela antecipada, em outras espécies de ação judicial; [...].
} 
dos investimentos nessas obras de infraestrutura, atraindo investimentos privados e beneficiando outras tantas pessoas que não só aquelas diretamente ligadas ao regime fiscal analisado.

Ocorre que o incentivo não vem sendo concedido de forma a atingir esse escopo extrafiscal e a atender aos anseios de ambas as partes da relação jurídica. O Poder Público deveria permitir que as empresas envolvidas nessa relação jurídica usufruíssem do benefício tão logo comprovassem o preenchimento dos requisitos de enquadramento no REIDI, ao mesmo tempo em que desenvolvem os projetos de infraestrutura nacional, atendendo ao escopo da norma extrafiscal e conciliando o interesse público com o particular de expansão da infraestrutura e redução da carga tributária.

Todavia, o que se observa hoje em dia é uma relação em que as concessionárias de transmissão de energia elétrica, acionadas pela agência reguladora do setor (ANEEL) para realizarem obras de reforço, ampliação ou implantação das linhas de transmissão, aplicam seu próprio capital para este fim e seguem estritamente um cronograma para a conclusão das obras, sob pena de sofrerem sanções previstas na legislação, como a revogação de suas autorizações, enquanto o Poder Público se abstém de cumprir sua parte no procedimento, deixando de analisar o requerimento de enquadramento das obras no REIDI em tempo razoável.

Agindo dessa forma, a Administração dificulta ou até mesmo impede que o benefício seja usufruído pelas empresas, violando princípios constitucionalmente previstos, como o do equilíbrio econômico-financeiro nas relações jurídicas e o da duração razoável do processo.

Dessa forma, diante desse quadro de desequilíbrio estabelecido entre o particular e o Poder Público, a alternativa que resta ao administrado é acionar o Poder Judiciário para assegurar seu direito à eficiência da Administração Pública e à razoável duração do procedimento administrativo, requerendo a suspensão da exigibilidade do PIS/PASEP e da COFINS incidentes sobre os projetos de infraestrutura requeridos pela ANEEL a partir do momento em que a agência reguladora certificar o preenchimento dos requisitos para o enquadramento no REIDI, sob condição resolutiva de sua ulterior declaração.

\section{Referências bibliográficas}

ÁVILA, Humberto. Teoria da segurança jurídica. 4. ed. rev. atual. e ampl. São Paulo: Malheiros, 2016. 
. Teoria dos princípios - da definição à aplicação dos princípios jurídicos. 16. ed. rev. e atual. São Paulo: Malheiros, 2015.

CHIGANER, Luis, et al. A reforma do setor elétrico brasileiro: aspectos institucionais. In: Encontro de Energia no Meio Rural, 2002, Campinas. Disponível em: http://www. proceedings.scielo.br/scielo.php?script=sci_arttext\&pid=MSC0000000022002000 $100007 \& \operatorname{lng}=$ en\&nrm=abn. Acesso em 12 de maio de 2018.

CORDEIRO, Rodrigo Aiache. Princípios Constitucionais Tributários. 1. ed. Porto Alegre: Sérgio Antonio Fabris, 2006.

JUSTEN FILHO, Marçal. Curso de direito administrativo, 9. ed. rev., atual. e ampl. São Paulo, SP: Revista dos Tribunais, 2013, p. 548 e 830.

MEDAUAR, Odete. Direito Administrativo Moderno. 11. ed. rev. e atual. São Paulo: Revista dos Tribunais, 2007.

MELLO, Celso Antônio Bandeira de. Curso de direito administrativo, 26. ed. rev. e atual. São Paulo: Malheiros, 2009.

MOREIRA, Egon Bockman. Contratos administrativos, equilíbrio econômico-financeiro e a taxa interna de retorno - a lógica das concessões e parcerias público-privadas. 1. ed. Belo Horizonte: Editora Fórum, 2016.

SCHOUERI, Luis Eduardo. Direito tributário. 7. ed. São Paulo: Editora Saraiva, 2017.

SGT ANEEL - Receita Anual Permitida - publicado em 25 de novembro de 2015, modificado em 02 de março de 2016. Disponível em http://www.aneel.gov.br/calculotarifario-e-metodologia//asset_publisher/6pqBPPJq59Ts/content/receita-anual-permitidarap/654800?inheritRedirect=false Acesso em 12 de maio de 2018.

TORRES, Heleno Taveira et al. (coord.) Direito tributário e processo administrativo aplicados.

São Paulo: Quartier Latin, 2005. 
TORRES, Ricardo Lobo. Curso de Direito Financeiro e Tributário. 19. ed. Rio de Janeiro: Editora Renovar, 2013.

WALD, Arnoldo. Pareceres: Direito das Concessões, v. 3. Rio de Janeiro: América Jurídica, 2004. 
E

—ste livro reúne artigos científicos apresentados e debatidos nos Grupos de Trabalho: "DIREITO EMPRESARIAL" e "DIREITO TRIBUTÁRIO E FINANCEIRO" no decorrer do VIII Encontro Internacional do CONPEDI (Conselho Nacional de Pesquisa e Pós-Graduação em Direito - Brasil), realizado entre os dias 06 e 08 de setembro de 2018 na cidade de Zaragoza - Espanha. 